$$
\begin{aligned}
& \text { UNIVERSIDADE DE SÃO PAULO } \\
& \text { PROGRAMA DE PÓS-GRADUAÇÃO EM ENERGIA } \\
& \text { EP - FEA - IEE - IF }
\end{aligned}
$$

SILVIO DE ANDRADE FIGUEIREDO

AVALIAÇÃO TÉCNICO-ECONÔMICA DAS PRINCIPAIS TENDÊNCIAS E ALTERNATIVAS DO TRANSPORTE RODOVIÁRIO NACIONAL SOB O PONTO DE VISTA ENERGÉTICO E AMBIENTAL 


\title{
AVALIAÇÃO TÉCNICO-ECONÔMICA DAS PRINCIPAIS TENDÊNCIAS E ALTERNATIVAS DO TRANSPORTE RODOVIÁRIO NACIONAL SOB O PONTO DE VISTA ENERGÉTICO E AMBIENTAL
}

\begin{abstract}
Tese apresentada ao Programa de PósGraduação em Energia da Universidade de São Paulo (Escola Politécnica / Faculdade de Economia e Administração / Instituto de Energia e Ambiente / Instituto de Física) para obtenção do título de Doutor em Ciências
\end{abstract}

Orientador: Prof. Dr. José Roberto Moreira 
AUTORIZO A REPRODUÇÃO E DIVULGAÇÃO TOTAL OU PARCIAL DESTE TRABALHO, POR QUALQUER MEIO CONVENCIONAL OU ELETRÔNICO, PARA FINS DE ESTUDO E PESQUISA, DESDE QUE CITADA A FONTE.

FICHA CATALOGRÁFICA

Figueiredo, Silvio de Andrade

Avaliação técnico-econômica das principais tendências e alternativas do transporte rodoviário nacional sob o ponto de vista energético e ambiental / Silvio de Andrade Figueiredo; orientador José Roberto Moreira. - São Paulo, 2013.

202 f.: il.; $30 \mathrm{~cm}$.

Tese (Doutorado) - Programa de Pós-Graduação em Energia - EP / FEA / IEE / IF da Universidade de São Paulo.

1. Transporte rodoviário. 2. Combustíveis. 3. Tecnologia veicular. 4. Gases de efeito estufa. 5. Poluição atmosférica.

1. Título 


\section{UNIVERSIDADE DE SÃO PAULO PROGRAMA DE PÓS-GRADUAÇÃO EM ENERGIA EP / FEA / IEE / IF}

\section{SILVIO DE ANDRADE FIGUEIREDO}

"Avaliação técnico-econômica das principais tendências e alternativas do transporte rodoviário nacional sob o ponto de vista energético e ambiental”

Tese defendida e aprovada pela Comissão Julgadora:

Prof. Dr. José Roberto Moreira - PPGE/USP

Orientador e Presidente da Comissão Julgadora

Prof $^{\mathrm{a}}$. Dr ${ }^{\mathrm{a}}$. Virgínia Parente - PPGE/USP

Prof. Dr. Francisco Emílio Baccaro Nigro - EP/USP

Prof $^{a}$. Dr ${ }^{\mathrm{a}}$. Suzana Khan Ribeiro - UFRJ

Dr. Rodrigo Galbieri - UNICAMP 
Dedico este trabalho a todos aqueles que, mesmo enfrentando grandes dificuldades, nunca esmoreceram em buscar, por meio da ciência, uma sociedade mais justa e mais humana...

...e a meu pai, por tudo que ele me ensinou. 


\section{AGRADECIMENTOS}

Ao Prof. Moreira, pela orientação, dedicação e criteriosa avaliação desta tese.

Ao Prof. Nigro, pelos ensinamentos ao longo de grande parte de minha vida profissional e seu apoio no desenvolvimento deste trabalho.

A meus colegas do IPT, Peral, Gimenez e Padovezi, e ao Instituto como um todo, por permitirem que eu me dedicasse a esta tarefa.

Aos colegas da CETESB e do IEMA, que compartilharam informações comigo.

Ao ICCT, pela visão que ele me forneceu durante o breve momento do qual eu dele participei.

E finalmente, à Malu, minha esposa, que mesmo diante de minhas aflições e dificuldades, pacientemente me amparou. 
"Although the environmental and health burden associated with motor vehicle use is pervasive and persistent, and the certain, rapid growth of the world fleet presents a tremendous challenge, there is cause for optimism." (THE ENERGY FOUNDATION. Bellagio Memorandum on Motor Vehicle Policy Principles for Vehicles and Fuels in Response to Global Environmental and Health Imperatives Consensus Document: 19-21 June, 2001. Bellagio, Italy.)

Definições para “Ato Nobre”, segundo a Nobre Casa de Cidadania, 2013.

“Um Ato Nobre é uma ação realizada em benefício de terceiros, ausente de qualquer interesse pessoal, refletindo o carácter de quem a pratica ao demonstrar integridade, honra e humanidade." 


\section{RESUMO}

FIGUEIREDO, Silvio de Andrade. Avaliação técnico-econômica das principais tendências e alternativas do transporte rodoviário nacional sob o ponto de vista energético e ambiental. 2013, 202 f. Tese (Doutorado em Ciências) - Programa de Pós-Graduação em Energia da Universidade de São Paulo, São Paulo, 2013.

Ferramentas computacionais, baseadas em modelos de inventários, que consigam predizer, com precisão apropriada, o consumo de combustíveis e as emissões veiculares, principais motivadores do desenvolvimento automotivo atual, são fundamentais para a elaboração de políticas públicas eficazes vinculadas a essas questões. No Brasil, apesar de afetarem significativamente a sociedade, muitas das intervenções governamentais nesse segmento são realizadas sem a adequada avaliação de seus impactos. Isso ocorre ou porque a importância dessas ferramentas nem sempre é reconhecida ou por não se ter ferramentas apropriadas. $\mathrm{O}$ objetivo deste trabalho foi o de desenvolver uma ferramenta de prognóstico do consumo de combustíveis e das emissões da frota rodoviária, estatisticamente consistente, que pudesse ser utilizada para esse propósito. Para tanto, inicialmente buscou-se identificar os aspectos relacionados às questões que deveriam ser considerados nesse desenvolvimento, por meio do levantamento das tendências evolutivas e alternativas que estão sendo apresentadas relativas a combustíveis, tecnologia veicular e sistemas de transportes. A seguir foram revistos os principais modelos e ferramentas públicos, nacionais e estrangeiros, dessa natureza. E, diante da constatação que eles não poderiam ser empregados, apesar dos limites impostos pela disponibilidade de dados, foi proposta uma nova abordagem para se atingir esse objetivo. Primeiro foi desenvolvido um conjunto de planilhas integrando todos os dados e cálculos de um modelo "bottom-up" similar ao utilizado nos inventários de emissões tóxicas nacionais, totalmente interconectado e configurado para facilitar, por meio de um processo iterativo, o ajuste fino das estimativas mais incertas, de forma que os consumos totalizados resultantes do modelo coincidissem tanto quanto possível com os consumos observados no país. A seguir, foram desenvolvidos modelos econométricos, para estimar os consumos totalizados de combustíveis a partir de indicadores econômicos pertinentes. E pela inserção desses modelos econométricos no modelo "bottom-up" anterior, foi gerado um modelo híbrido que permite inventariar e prognosticar, segregadas por classes, o consumo de combustíveis e as emissões veiculares. Os consumos de combustíveis obtidos por meio desses modelos, quando comparados com valores observados, forneceram resultados estatisticamente robustos, que podem ser, em algumas condições, convertidos na emissão de $\mathrm{CO}_{2}$. $\mathrm{O}$ mesmo não é possível afirmar com relação às demais emissões, inclusive em função da dificuldade de vincular as fontes emissoras a indicadores de qualidade do ar, o que não invalida o uso do modelo híbrido para obtenção de resultados comparativos. Finalmente, os modelos foram submetidos a análise sensibilidade e sua aplicabilidade foi verificada para alguns cenários.

Palavras chaves: Transporte rodoviário; Combustíveis; Veículos rodoviários; Tecnologia veicular; Emissão veicular; Gases de efeito estufa; Poluição atmosférica; Inventário. 


\begin{abstract}
FIGUEIREDO, Silvio de Andrade. Technical economical evaluation of the main tendencies and alternatives of the Brazilian on-road transportation under energy and environmental perspectives. 2013, 202 p. PhD Thesis - Graduate Program on Energy, Universidade de São Paulo, São Paulo, 2013.
\end{abstract}

Computational tools, based on inventory models, which are able to predict, with the appropriated accuracy, vehicular fuel consumption and emissions, main current drivers of the automotive development, are essentials for the development of effective public policies related to these issues. In Brazil, despite their significantly influence over the society, many government interventions in this segment are undertaken without the adequate assessment of their impacts. This happen because the importance of these tools is not always recognized or because proper tools are not available. The goal of this study was to develop a statistically consistent prognostic tool of road fuel consumption and emissions, which could be used for this purpose. Initially, by surveying the evolutionary trends and known alternatives related to fuels, vehicular technology and transportation systems, it was examined all the aspects that should be considered for this work. Next it was reviewed the main domestic and foreign public models and tools of this sector. Realizing that they could not be used, due to the limits imposed by data availability, it is proposed a new approach to achieve this goal. First it is developed a set of worksheets integrating all data and calculations of a bottom-up model, similar to the ones used in national inventories of toxic emissions. The set was interconnected and configured to facilitate, through an iterative process, the fine tuning of the uncertain estimates, in such way that the model total consumptions as much as possible reproduce the fuel consumptions observed in the country. Next econometric models were developed to estimate total fuel consumptions based on identified relevant economic indicators. And inserting these econometric models in the previous bottom-up model, it was generated a hybrid model that allows inventorying and forecasting of fuel consumptions and vehicular emissions segregated by classes. When compared with the observed fuel consumptions, these models presented statistically robust results. Under some conditions, these results can be converted in $\mathrm{CO}_{2}$ emissions. The same cannot be said with respect to other emissions, partially due to the difficulty to link emission sources to air quality measurements, which does not invalidate the use of the hybrid model to obtain comparative results for these emissions. Finally, the models were submitted to a sensitivity analysis and their applicability was verified for some scenarios.

Keywords: On-road transport; Fuels; On-road vehicles; Vehicular technology; Vehicular Emission; Greenhouse gases; Air pollution; Inventory. 


\section{LISTA DE ILUSTRAÇÕES}

Ilustração 2.1 - Diferenças entre os benefícios na redução da emissão de GEE proporcionado pelo etanol como substituto da gasolina, observadas em diferentes ACV, sem LUC.

Ilustração 2.2 - Resultados da ACV de GEE de biocombustíveis tomando a gasolina como referência, segundo estudo da USEPA

Ilustração 2.3 - Custo incremental de combustíveis alternativos em função de seus potenciais de redução de emissão de GEE em relação a gasolina, ao custo de petróleo de US\$ 120 por barril, segundo a IEA. 24

Ilustração 2.4 - Projeções da capacidade de produção de etanol brasileiro. .33

Ilustração 2.5 - Projeções da capacidade de exportação de etanol brasileiro 33

Ilustração 2.6 - Número de veículos leves novos vendidos por combustível no Brasil........ 36

Ilustração 2.7 - Participação nas vendas de veículos leves novos por combustível. 37

Ilustração 2.8 - Evolução do consumo e preço médio anual dos combustíveis rodoviários no Brasil.

Ilustração 2.9 - Evolução do preço médio mensal dos combustíveis rodoviários no Brasil. 39

Ilustração 2.10 - Evolução dos consumos mensais e dos preços dos combustíveis Otto.

Ilustração 2.11 - Exemplos de mapas de eficiência de motores ciclo Otto e ciclo Diesel.

Ilustração 2.12 - Mapa de consumo de veículo no WLTC sobreposto aos regimes do motor operando com dois diferentes tipos de transmissão automática 57

Ilustração 2.13 - Previsão do volume de vendas de transmissões por $n^{\circ}$ de marchas 57

Ilustração 2.14 - Participação nas vendas dos tipos de transmissões por região 58

Ilustração 2.15 - Exemplo do aperfeiçoamento aerodinâmico dos caminhões. 60

Ilustração 2.16 - Evolução recente dos motores GDI a plena carga. 63

Ilustração 2.17 - Evolução da eficiência dos motores GDI em carga parcial 63

Ilustração 2.18 - Curvas das novas gerações de motores. 64

Ilustração 2.19 - Previsão da participação nas vendas de motores GDI. 65 
Ilustração 2.20 - Sistema de virabrequins articulados para Ciclo Atkinson. 66

Ilustração 2.21 - Potencial de ganhos de eficiência energética para diferentes tecnologias aplicáveis a veículos leves.

Ilustração 2.22 - Potencial de ganhos de eficiência energética para diferentes tecnologias e medidas aplicáveis a veículos pesados

Ilustração 2.23 - Potencial de redução de consumo das diferentes tecnologias aplicadas aos diferentes segmentos dos veículos pesados 77

Ilustração 2.24 - Previsão da evolução das vendas de veículos leves de passageiros por tecnologia para dois diferentes cenários, segundo a IEA. .78

Ilustração 2.25 - Consumo de veículos leves - Histórico da evolução recente, metas impostas pela legislação vigente e metas em discussão.

Ilustração 2.26 - Projeção horizontal do veículo utilizada para caracterizar o porte do veículo utilizado nos EUA e Canada.

Ilustração 2.27 - Veículos leves - Posicionamento no mercado e emissões médias de $\mathrm{CO} 2 / \mathrm{km}$ por fabricante observadas na Comunidade Europeia em 2010. ....82

Ilustração 2.28 - Histórico e projeção da participação das tecnologias nas regiões................. 82

Ilustração 2.29 - Matriz energética mundial em 2010 (valores em Mtep). ............................ 87

Ilustração 2.30 - Consumo energético global em transportes por fonte e modo em 2010 ...... 87

Ilustração 2.31 - Crescimento do consumo dos transportes por modo projetado até 2030 no cenário "políticas atuais".... .88

Ilustração 2.32 - Demanda global de petróleo por setor no cenário "novas políticas” 88

Ilustração 2.33 - Histórico e projeção da evolução das frotas de automóveis por região no cenário "novas políticas".

Ilustração 2.34 - Histórico e projeção da evolução das vendas e das frotas de caminhões por região no cenário "novas políticas".

Ilustração 2.35 - Consumo global e preço do petróleo projetados para diferentes cenários. ..90

Ilustração 2.36 - Consumo anual de derivados de petróleo e de gás natural por uso. 90

Ilustração 2.37 - Composição setorial do consumo de derivados de petróleo. 
Ilustração 2.38 - Consumo energético nacional em transportes por fonte e modo em 2010. .91

Ilustração 2.39 - Evolução da frota de veículos leves. ...........................................................93

Ilustração 2.40 - Evolução da frota de veículos pesados........................................................94

Ilustração 2.41 - Metas de migração modal do Plano Nacional de Logística e Transportes. .96

Ilustração 2.42 - Metas de migração modal do Plano Diretor de Desenvolvimento de Transportes do Estado de São Paulo ........................................................ 96

Ilustração 3.1 -.Esquema de operação do MOVES. ............................................................ 119

Ilustração 4.1 - Taxas de sobrevivências do "10 Inventário" do MMA e do "MOVES 2010". 126

Ilustração 4.2 - Taxa de acumulação de quilometragem ("intensidade de uso") do "10 Inventário" do MMA e do "Relatório 2012” da CETESB......................... 126

Ilustração 4.3 - Taxa de acumulação de quilometragem relativa do "MOVES 2010”. 127

Ilustração 4.4 - Evolução dos consumos observados e estimados no "10 Inventário Nacional”. 129

Ilustração 4.5 - Ajuste do modelo "bottom-up" - Otto anual no Brasil. 133

Ilustração 4.6 - Evolução relativa das frotas e dos consumos no Brasil e em São Paulo.... 135

Ilustração 4.7 - Ajuste do modelo econométrico - Otto mensal no Brasil e em São Paulo. 139

Ilustração 4.8 - Ajuste do modelo econométrico - Otto anual no Brasil e em São Paulo... 140

Ilustração 4.9 - Ajuste do modelo econométrico - Diesel mensal no Brasil e em São Paulo.

Ilustração 4.10 - Ajuste do modelo econométrico - Diesel anual no Brasil e em São Paulo.142

Ilustração 4.11 - Ajuste do modelo econométrico - Otto anual no Brasil............................. 143

Ilustração 4.12 - Ajuste do modelo econométrico - Otto anual no Brasil............................. 145

Ilustração 4.13 - Ajuste do modelo híbrido - Otto no Brasil e em São Paulo. ........................ 146

Ilustração 4.14 - Ajuste do modelo híbrido - Diesel no Brasil e em São Paulo..................... 147

Ilustração 4.15 - Projeção da evolução de vendas e parcelas de motociclos novos...............149

Ilustração 4.16 - Projeção da evolução de vendas e parcelas de veículos leves novos......... 150 
Ilustração 4.17 - Projeção da evolução de parcelas e vendas de veículos pesados novos. ...151

Ilustração 4.18 - Ajuste do modelo híbrido em função do modelo econométrico. 153

Ilustração 4.19 - Projeção da evolução do consumo Otto em função da economia. 155

Ilustração 4.20 - Projeção da evolução do consumo Diesel em função da economia. 156

Ilustração 4.21 - Projeção da evolução do consumo em função das metas do Inovar-Auto. 157

Ilustração 4.22 - Projeção da evolução do consumo Otto e Diesel por classes. 158

Ilustração 4.23 - Projeção da evolução da emissão de CO2 em São Paulo por classes. 159

Ilustração 4.24 - Cenários da emissão de CO2 em São Paulo 160

Ilustração 4.25 - Evolução das emissões predominantemente Otto em São Paulo. 163

Ilustração 4.26 - Evolução das emissões predominantemente Diesel em São Paulo. 164

Ilustração 4.27 - Evolução da emissão calculada de NOX veicular e das concentrações medias anuais de NO2 em São Paulo 165

Ilustração 4.28 - Evolução da emissão calculada de MP veicular e das concentrações médias anuais de MP2,5 em São Paulo. 166 


\section{LISTA DE TABELAS}

Tabela 2.1 - Contribuições das emissões veiculares de CH4 e N2O ao efeito estufa. .............. 8

Tabela 2.2 - Emissão de $\mathrm{CO} 2$ devida às propriedades físico-químicas dos combustíveis veiculares

Tabela 2.3 - Taxa de emissão de CO2 relativa desconsiderando WTT da ACV.

Tabela 2.4 - Cenários hipotéticos sobre as emissões líquidas relativas de GEE da parcela WTT dos biocombustíveis brasileiros

Tabela 2.5 - Taxas de emissão de CO2 relativa em \% considerando ou não WTT da ACV...23

Tabela 2.6 - Programas internacionais prevendo o uso de biocombustíveis ou etanol. 32

Tabela 2.7 - Quadro comparativo das principais características dos diferentes híbridos. 72

Tabela 2.8 - Veículos leves - Evolução das metas de emissão de GEE. 79

Tabela 2.9 - Veículos leves - Emissões médias de CO2/km por fabricante observadas na Comunidade Europeia em 2010. .81

Tabela 2.10 -Cronograma dos programas de redução de consumo para veículos pesados......84

Tabela 2.11 -Principais características dos programas para veículos pesados. 84

Tabela 2.12 -Metas do programa para veículos pesados vigente no Japão. 85

Tabela 2.13 -Metas do programa para veículos pesados vigente nos Estados Unidos 85

Tabela 2.14 -Prognósticos do Plano Nacional de Energia 2030. 92

Tabela 3.1 - Fatores de emissão pré-definidos dos principais combustíveis veiculares no “2006 IPCC Guidelines for National GHG Inventories" 102

Tabela 3.2 - "EMEP/EEA guidebook 2009 - Tier 3" - Dados de entrada

Tabela 3.3 - “EMEP/EEA guidebook 2009 - Tier 3” - Variáveis intermediárias

Tabela 3.4 - "EMEP/EEA guidebook 2009 - Tier 3” - Variáveis intermediárias

Tabela 4.1 - Valores médios de consumo de veículos com motores ciclo Diesel. 128

Tabela 4.2 - Crescimento relativo do PIB nos diversos cenários econômicos. 153 


\section{LISTA DE ABREVIATURAS E SIGLAS}

ABEIVA Associação Brasileira das Empresas Importadoras de Veículos Automotores

ABRACICLO Associação Brasileira dos Fabricantes de Motocicletas, Ciclomotores, Motonetas, Bicicletas e Similares

ACV Análise do Ciclo de Vida

AFOLU Agriculture, Forestry and Other Land Use

ANFAVEA Associação Nacional dos Fabricantes de Veículos Automotores

ANL

Argonne National Laboratory

ANP

Agência Nacional de Petróleo, Gás Natural e Biocombustíveis

APBF

Advanced Petroleum Based Fuels program, do NREL

BEN

Balanço Energético Nacional

BEV

Battery Electric Vehicle

BMEP

Brake Mean Effective Pressure

BSFC

Brake Specific Fuel Consumption

CAGR

Compounded Annual Growth Rate

CARB

California Air Resources Board

CDPF

Catalyzed Diesel Particulate Filter

CETESB Companhia Ambiental do Estado de São Paulo

CLRTAP Convention on Long Range Transboundary Air Pollution

CORINE Co-oRdination d'Information Environnementale

CVT

Continuously Variable Transmission

DENATRAN Departamento Nacional de Trânsito

DOC

Diesel Oxidation Catalyst

DPF

Diesel Particulate Filter

EAC

Etanol Anidro Carburante

EC

European Commission, comitê executivo da EU

EEA

European Environment Agency

EFTE

European Federation for Transport and Environment

EHC

Etanol Hidratado Carburante

EMEP

European Monitoring and Evaluation Programme

EPE

Empresa de Pesquisa Energética

ETC/AE

European Topic Centre on Air Emissions

EU

European Union

FCEV

Fuel Cell Electric Vehicle 
Fator de Emissão

GDI

Gasoline Direct Injection

GEE

Gases de Efeito Estufa

GLP

Gás Liquefeito de Petróleo

GN

Gás Natural

GNC

Gás Natural Comprimido

GNL

Gás Natural Liquefeito

GNV

Gás Natural Veicular

GWP

Global Warming Potential

HCCI

Homogeneous Charge Compression Ignition

HV

Hybrid Vehicle

HEV

Hybrid Electric Vehicle

IHS

Information Handling Services, empresa de consultoria

$\mathrm{I} / \mathrm{M}$

Programa de Inspeção e Manutenção Veicular

IBAMA

Instituto Brasileiro do Meio Ambiente e dos Recursos Naturais Renováveis

ICCT

International Council on Clean Transportation

IEA

International Energy Agency

IEMA

Instituto de Energia e Meio Ambiente

ILUC

Indirect Land Use Change

INPC

Índice Nacional de Preços ao Consumidor

IPCC

Intergovernmental Panel on Climate Change

IPEA

Instituto de Pesquisa Econômica Aplicada

IPT

LNT

Instituto de Pesquisas Tecnológicas do Estado de São Paulo

LUC

Lean NOx Trap

MCT

Land Use Change

MENA

MMA

Ministério de Ciência e Tecnologia

MME

Middle East and North Africa

MOVES

Ministério de Meio Ambiente

NFR

Ministério das Minas e Energia

NRC

Motor Vehicle Emission Simulator

NREL

Nomenclature for Reporting, da UNECE

National Research Council, dos Estados Unidos

OECD

National Renewable Energy Laboratory, dos Estados Unidos

OEM

Organisation for Economic Co-operation and Development

Original Equipment Manufacturer 
OVEG Programa de Óleos Vegetais

PDDT Plano Diretor de Desenvolvimento de Transportes

PETROBRAS Petróleo Brasileiro S.A.

PHEV Plug-in Hybrid Electric Vehicle

PNA Plano Nacional de Agroenergia

PNAD Pesquisa Nacional por Amostra de Domicílios

PNLT Plano Nacional de Logística e Transportes

Proálcool Programa do Álcool

PROCONVE Programa de Controle de Poluição do Ar por Veículos Automotores

RFS

Renewable Fuel Standard

RMSP Região Metropolitana de São Paulo

SCR Selective Catalyst Converter

SI

Sistema Internacional de Unidades

Sindipeças Sindicato Nacional da Ind. de Componentes para Veículos Automotores

SNAP

Selected Nomenclature for Air Pollution, da EEA

TAQ

Taxa de Acumulação de Quilometragem

TAQR

Taxa de Acumulação de Quilometragem Relativa

TFEIP

Task Force on Emission Inventories and Projections

UCSD University of California, San Diego

UNECE

United Nations Economic Commission for Europe

UNEP

United Nations Environment Programme

UNFCCC

United Nations Framework Convention on Climate Change

UNICA

Associação dos Produtores de Açúcar e Álcool do Estado de SP

USDOE

United States Department of Energy

USEPA

United States Environmental Protection Agency

USP

Universidade de São Paulo

VKT

Vehicle Kilometers Traveled

VSP

Vehicle Specific Power

WEF

World Economic Forum

WEO

World Energy Outlook

WLTC

World Light-duty Test Procedure

WMO

World Meteorological Organization

WTT

Well-To-Tank 


\section{LISTA DE SÍMBOLOS}

\begin{tabular}{|c|c|}
\hline $\mathrm{B}(\mathrm{a}) \mathrm{P}$ & benzo[a]pireno \\
\hline $\mathrm{B}(\mathrm{b}) \mathrm{F}$ & benzo[b]fluoranteno \\
\hline $\mathrm{BC}$ & carbono negro (sigla em inglês) \\
\hline $\mathrm{B}(\mathrm{k}) \mathrm{F}$ & benzo[k]fluoranteno \\
\hline $\mathrm{CF}_{4}$ & tetrafluormetano \\
\hline $\mathrm{CFC}$ & clorofluorcarbonetos \\
\hline $\mathrm{CH}_{4}$ & metano \\
\hline $\mathrm{CO}$ & monóxido de carbono \\
\hline $\mathrm{CO}_{2}$ & dióxido de carbono \\
\hline $\mathrm{COV}$ & compostos orgânicos voláteis \\
\hline COVNM & compostos orgânicos voláteis não metano \\
\hline $\mathrm{Cu}$ & cobre \\
\hline DME & dimetil éter \\
\hline FAME & esteres metílicos de ácidos graxos (sigla em inglês) \\
\hline G & giga, prefixo do SI para o fator multiplicador $10^{9}$ \\
\hline $\mathrm{g}$ & grama \\
\hline $\mathrm{H}_{2} \mathrm{SO}_{4}$ & ácido sulfúrico \\
\hline $\mathrm{HC}$ & hidrocarbonetos \\
\hline HCNM & hidrocarbonetos não metano \\
\hline HFC & hidrofluorcarbonetos \\
\hline HPA & hidrocarbonetos policíclicos aromáticos \\
\hline $\operatorname{ID}(1,2,3-\mathrm{cd})$ & indeno(1,2,3-cd)pireno \\
\hline J & Joule \\
\hline $\mathrm{k}$ & kilo, prefixo do SI para o fator multiplicador $10^{3}$ \\
\hline K & potássio \\
\hline M & mega, prefixo do SI para o fator multiplicador $10^{6}$ \\
\hline $\mathrm{m}$ & metro \\
\hline $\mathrm{Mb} / \mathrm{dia}$ & milhões de barris por dia \\
\hline MP & material particulado \\
\hline $\mathrm{MP} x$ & material particulado com tamanho inferior a $x \mu \mathrm{m}$ \\
\hline $\mathrm{N}_{2}$ & nitrogênio \\
\hline $\mathrm{N}_{2} \mathrm{O}$ & óxido nitroso \\
\hline $\mathrm{NF}_{3}$ & trifluoreto de nitrogênio \\
\hline
\end{tabular}




$\begin{array}{ll}\left(\mathrm{NH}_{2}\right)_{2} \mathrm{CO} & \text { ureia } \\ \mathrm{NH}_{3} & \text { amônia } \\ \mathrm{NO} & \text { óxido nítrico } \\ \mathrm{NO}_{2} & \text { dióxido de nitrogênio } \\ \mathrm{NO}_{\mathrm{X}} & \text { óxidos de nitrogênio } \\ \mathrm{O}_{3} & \text { ozônio } \\ \mathrm{P} & \text { peta, prefixo do SI para o fator multiplicador } 10^{15} \\ \mathrm{~Pb} & \text { chumbo } \\ \mathrm{PFC} & \text { perfluorcarbonetos } \\ \mathrm{POP} & \text { poluentes orgânicos persistentes } \\ \mathrm{ppm} & \text { partes por milhão } \\ \mathrm{Pt} & \text { platina } \\ \mathrm{RCHO} & \text { aldeídos } \\ \mathrm{S} & \text { enxofre } \\ \mathrm{Si} & \text { silício } \\ \mathrm{S} x & \text { teor de enxofre do combustível, em } x \text { ppm } \\ \mathrm{SF} & \text { hexafluoreto de enxofre } \\ \mathrm{SO}{ }_{2} & \text { dióxido de enxofre } \\ \mathrm{SO} & \text { óxidos de enxofre } \\ \mathrm{T} & \text { tera, prefixo do SI para o fator multiplicador } 10^{12} \\ \text { tep } & \text { tonelada equivalente de petróleo } \\ { }^{\circ} \mathrm{C} & \text { graus Celsius } \\ \% & \text { porcentagem } \\ & \text { mícron, prefixo do SI para o fator multiplicador } 10^{-6}\end{array}$




\section{SUMÁRIO}

1 INTRODUÇÃ

2 O COMPLEXO CONTEXTO PARA O DESENVOLVIMENTO DO MODELO........5

2.1 A RELAÇÃo ENTRE O CONSUMO DE COMBUSTíveIS E AS EMISSÕES DE GASES DE EFEITO

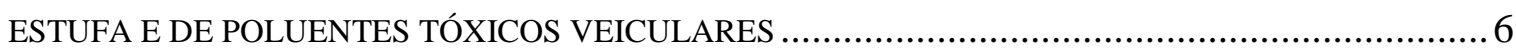

2.2 CARACTERIZAÇÃO E PERSPECTIVAS EVOLUTIVAS DOS COMBUSTÍVEIS, DA TECNOLOGIA

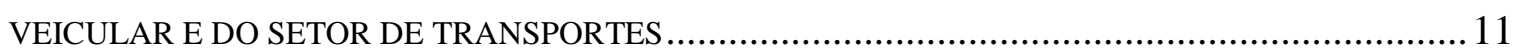

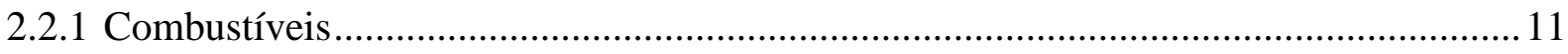

2.2.1.1 Projeções do mercado de combustíveis veiculares.................................................... 12

2.2.1.2 Comparando a emissão de $\mathrm{CO} 2$ dos principais combustíveis veiculares.................... 16

2.2.1.3 O desenvolvimento de combustíveis mais limpos .............................................23

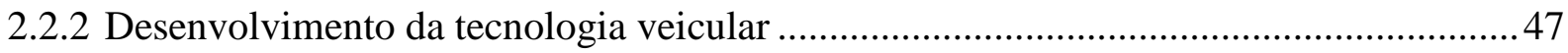

2.2.2.1 Aprimoramento de tecnologias convencionais ..................................................... 48

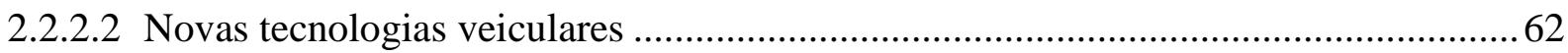

2.2.2.3 Potencial da evolução da tecnologia veicular .......................................................... 75

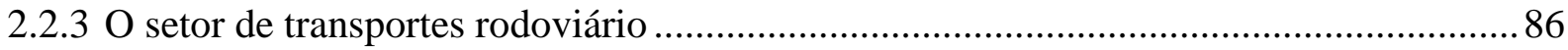

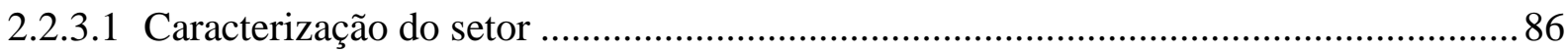

2.2.3.2 Outras formas de evoluir o sistema de transporte rodoviário.....................................94

3 REVISÃO DOS PRINCIPAIS MODELOS DE INVENTÁRIOS ...............................98

3.12006 IPCC GUIDELINES FOR NATIONAL GREENHOUSE GAS INVENTORIES........................99

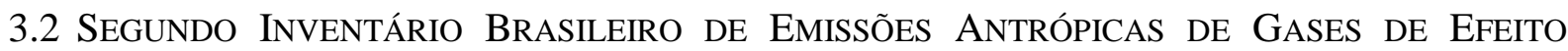

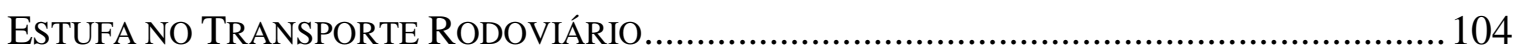

3.3 EMEP/EEA Air Pollutant EMISSION InVENTORy GuIDEBook 2009 .......................... 107

3.4 Primeiro Inventário Nacional de Emissões AtMosféricas por Veículos

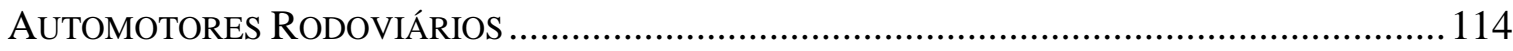

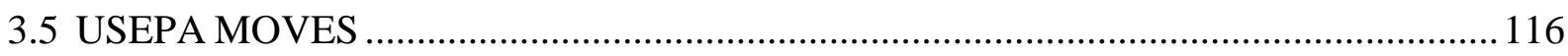

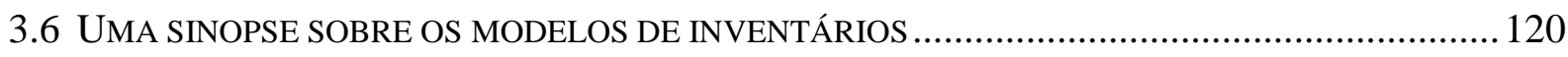




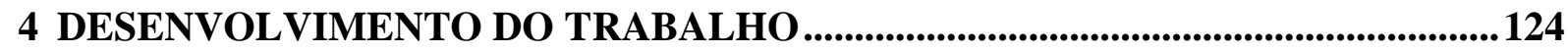

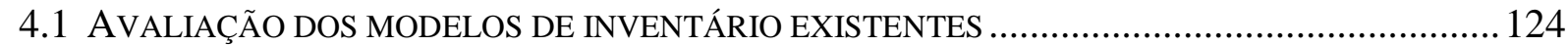

4.2 APERFEIÇOAMENTO DO MODELO “BOTTOM-UP” ....................................................... 130

4.3 DESENVOLVIMENTO DO MODELO ECONOMÉTRICO …...................................................... 134

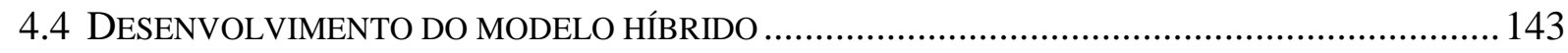

4.5 PREMISSAS AdOTADAS PARA A REALIZAÇÃO DAS PROJEÇÕES ......................................... 148

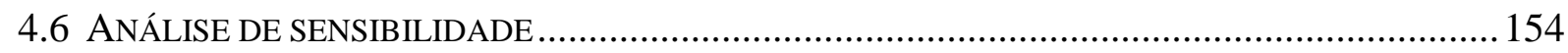

4.7 APLICAÇÃO DOS MODELOS DESENVOLVIDOS PARA A PROJEÇÃO DE ALGUNS CENÁRIOS .... 154

5 CONCLUSÕES E CONSIDERAÇÕES FINAIS....................................................167 


\section{INTRODUÇÃO}

Temas como o agravamento dos congestionamentos, dos acidentes, da poluição do ar e da mudança climática, e o correspondente crescimento de seus danos à saúde pública e de seus custos socioeconômicos, somados a questões fundamentais como a disponibilidade de combustíveis, segurança energética e a ocupação do solo, estão provocando pressões cada vez maiores por mudanças nos padrões de transporte atualmente utilizados. Isso tem refletido em significativos investimentos que governos e a indústria automotiva vêm realizando para fazer frente a esses desafios.

Por outro lado, não se pode relegar a importância da mobilidade para a população. Mobilidade significa acesso a bens, serviços, trabalho, educação, saúde, cultura e lazer. O compromisso entre mobilidade, bem estar social, desenvolvimento econômico e meio ambiente é apropriadamente resumida na introdução do recém-publicado “White Paper" da Comissão Europeia (EC, sigla em inglês) (2011, pg. 3 e 4).

Transporte é fundamental para nossa economia e sociedade. Mobilidade é vital para o mercado interno e para a qualidade de vida dos cidadãos que apreciam sua liberdade de deslocar-se. Transporte possibilita o crescimento econômico e a criação de emprego, mas ele deve ser sustentável face aos novos desafios que se colocam. [...]

A futura prosperidade de nosso continente dependerá da habilidade de todas suas regiões manterem-se completamente e competitivamente integradas na economia mundial. E transporte eficiente é vital para fazer isso acontecer. [...]

Novas tecnologias veiculares e de gerenciamento de tráfego são elementos chaves para reduzir as emissões dos transportes na União Europeia (EU, sigla em inglês) e no mundo em geral. A corrida pela mobilidade sustentável é global. Ações tardias e tímidas introduções de novas tecnologias podem condenar a indústria de transportes da EU a um declínio irreversível. O setor de transportes da EU enfrenta crescente competição nos, em rápido desenvolvimento, mercados mundiais de transporte.

Muitas companhias europeias são líderes mundiais em infraestrutura, logística, sistemas de gerenciamento de tráfego e na produção de equipamentos de transporte. Porém, à medida que outras regiões do mundo lançam grandes $e$ ambiciosos programas de modernização dos transportes e de investimento em infraestrutura, é crucial que o setor de transportes europeu continue a se desenvolver e a investir para manter sua competitividade.

Infraestrutura molda a mobilidade. Nenhuma mudança significativa nos transportes será possível sem a base de uma rede adequada e de uma maior racionalidade para utilizá-la. De maneira geral, investimentos em infraestrutura de transporte tem um impacto positivo no crescimento econômico, geram riquezas e trabalho, e incrementam o comércio, a acessibilidade geográfica e a mobilidade das pessoas. Todavia, ela deve ser planejada de forma a maximizar os impactos positivos no crescimento econômico e a minimizar os impactos negativos no meio ambiente. 
Apesar de referirem-se ao contexto europeu, obviamente, os mesmos conceitos dos excertos destacados acima são válidos também para nosso continente e para nosso país. Mas como dar maior racionalidade aos transportes no Brasil, em particular ao transporte rodoviário, de forma a buscar conciliar essas questões? Essa é a motivação básica deste estudo.

Dada sua correlação com as questões anteriormente mencionadas, os principais motivadores do atual desenvolvimento são hoje o consumo de combustíveis e as emissões veiculares. Esses são afetados por diversos aspectos que vão desde a infraestrutura existente à intermodalidade, da constituição da frota à sua condição de operação, das características dos veículos aos combustíveis utilizados. Convém ressaltar nesse ponto a estreita correlação que existe entre o consumo de combustíveis veiculares e a emissão de gases de efeito estufa.

Grande parte do que vem ocorrendo no Brasil deriva de intervenções governamentais. As recentes evoluções tecnológicas dos combustíveis e dos veículos vêm acontecendo não somente induzidas por questões de mercado, mas, sobretudo em função da introdução dos novos requisitos legais, principalmente relacionados à questão ambiental, como por exemplo, o Programa de Controle de Poluição do Ar por Veículos Automotores (PROCONVE). Há diversos exemplos de políticas públicas nacionais que impactaram na frota, desde mudanças nos preços relativos dos combustíveis à introdução de novos combustíveis (ex. etanol, gás natural e biodiesel); da introdução dos veículos "flex" à implantação dos programas de inspeção; do estímulo à aquisição de automóveis (ex. redução de impostos e extensão dos prazos de financiamento) ao incentivo ao transporte não motorizado (ex. ciclovias) ou público (ex. faixas exclusivas para ônibus e extensão das linhas do metro); da restrição à circulação (ex. adoção do rodízio e da Zona de Máxima Restrição de Circulação paulistanos) ao aperfeiçoamento da infraestrutura viária (ex. Rodoanel da Região Metropolitana de São Paulo).

Para avaliar-se o impacto de intervenções dessa natureza em tópicos correlacionados ao consumo e às emissões veiculares utilizam-se modelos de previsão, comumente baseados em inventários que extrapolam seus resultados para o futuro em função das tendências evolutivas dos aspectos pertinentes ao objeto do estudo.

A importância e a precisão dessas ferramentas para subsidiar a elaboração das políticas públicas eficazes são destacadas pela prof ${ }^{a}$. McGlade, Diretora Executiva da Agência Ambiental Europeia (EEA, sigla em inglês) (2009, pg.3).

Acesso a dados de emissões poluentes atmosféricos de alta qualidade é um elemento chave para suportar a elaboração de políticas públicas consistentes. Eles ajudam a melhor formatar e definir prioridades ambientais, aprimorar a 
modelagem da qualidade do ar, avaliar o atendimento às metas nacionais $e$ internacionais e avaliar a efetividade das intervenções políticas no que tange a proteção da saúde humana e o meio ambiente.

Em grande parte, poluentes atmosféricos e gases de efeito estufa são emitidos pelas mesmas fontes. Como tais, bem desenhadas estratégias de mitigação da poluição do ar e da mudança climática podem fornecer cobenefícios em termos de aprimorar a qualidade do ar e reduzir as emissões de gases de efeito estufa. [...]

Esta foi também a conclusão do Conselho Nacional de Pesquisas estadunidense (NRC, sigla em inglês) (2000) que avaliou e julgou a ferramenta anteriormente utilizada pela Agência de Proteção Ambiental desse país (USEPA, sigla em inglês) muito imprecisa para reproduzir as emissões dos veículos em condições reais de uso, o que, consequentemente, poderia levar à implantação de políticas ineficazes com possíveis impactos negativos no meio ambiente, na saúde e na aplicação dos recursos públicos, o que a induziu a desenvolver uma nova ferramenta.

No Brasil, apesar de afetarem significativamente a sociedade, de maneira geral, muitas dessas intervenções governamentais são realizadas sem a apropriada avaliação de seus impactos no consumo de combustível e nas emissões, mesmo que esses sejam seus objetivos. Isso ocorre porque a importância dessas ferramentas nem sempre é reconhecida, ou porque as ferramentas existentes, em geral em função da falta de dados estatísticos e experimentais apropriados, não são capazes de modelar adequadamente a condição que se deseja analisar. Por exemplo, não existem ferramentas nacionais capazes de avaliar o impacto do aperfeiçoamento da infraestrutura viária. Para tanto, o modelo de predição teria que conter grandezas que refletissem essa melhoria, tais como a distribuição do perfil de velocidades da frota em uso.

Apesar dos limites impostos pela disponibilidade de dados, o objetivo deste trabalho foi de, por meio de uma abordagem diferenciada, obter uma ferramenta que possibilitasse, segundo critérios estatisticamente consistentes, prognosticar a evolução do consumo de combustíveis e das emissões de gases de efeito estufa e de poluentes tóxicos da frota rodoviária. Visando subsidiar a elaboração de políticas públicas relacionados a esses temas, essa ferramenta deveria, além de permitir a projeção das tendências evolutivas dessas grandezas, ter recursos para avaliar o impacto das principais alternativas que vêm sendo propostas para aprimorar o atual padrão de transporte rodoviário nacional.

Com esse objetivo, primeiro foram levantados os principais aspectos relacionados à questão, tanto para verificar as tendências do setor, como para identificar aqueles que conviriam fossem 
considerados no desenvolvimento da ferramenta proposta. Em função da complexidade desse contexto, essa abordagem sistêmica resultou em um grande conjunto de informações.

Depois, foram pesquisados e revistos os principais modelos oficiais e públicos existentes utilizados para esse fim. Posteriormente, diante da constatação que a falta de dados adequados inviabilizam, para a realização dessas projeções, tanto o uso dos modelos e ferramentas estrangeiras mais sofisticadas como dos modelos brasileiros existentes, foram desenvolvidos:

a) Uma ferramenta integrando todos dados e cálculos do basicamente mesmo modelo "bottomup" utilizado nos inventários de emissões tóxicas nacionais, objetivando facilitar a visualização do impacto que, na ausência de melhor informação, dados estimados causam nos resultados de consumo de combustíveis totalizados gerados pelo modelo. Destaque-se que as únicas referências consistentes disponíveis para o ajuste desses modelos "bottom-up" são os consumos de combustíveis equivalentes observados no país. Foram também introduzidos nessa ferramenta alguns recursos para facilitar a manipulação dos dados.

b) Modelos econométricos para estimar, a partir de indicadores econômicos identificados pertinentes, os consumos totalizados de combustíveis do Brasil e do estado de São Paulo. Esses resultados, em conjunto com dados ou estimativas da participação dos diferentes combustíveis veiculares, permitem obter, por meio de modelos "top-down", as correspondentes emissões totalizadas de dióxido de carbono $\left(\mathrm{CO}_{2}\right)$.

c) Pela inserção dos modelos econométricos no modelo "bottom-up" anterior, um modelo híbrido que permite avaliar, segregadas por classes, o consumo e as emissões veiculares.

Os consumos de combustíveis obtidos por meio dos modelos econométricos e híbrido, quando comparados com os valores observados, forneceram resultados estatisticamente robustos. O mesmo não é possível afirmar com relação às demais emissões, inclusive em função da dificuldade de vincular os resultados das fontes emissoras a indicadores de qualidade do ar. Isso não invalida o uso do modelo híbrido para desenvolver avaliações comparativas.

Finalmente, a sensibilidade dos modelos é analisada e são constituídos alguns cenários para verificar sua aplicabilidade.

As mais importantes contribuições deste trabalho foram estabelecer as bases de modelos econométricos que possibilitam prognosticar consistentemente o consumo energético do setor rodoviário nacional, e a técnica empregada para a elaboração do modelo híbrido, que permite mais precisamente inventariar, segregar e projetar o consumo e as emissões veiculares. 


\section{O COMPLEXO CONTEXTO PARA O DESENVOLVIMENTO DO MODELO}

O levantamento abaixo, que visou identificar as tendências e os aspectos relacionados à questão a serem levados em consideração no desenvolvimento da ferramenta proposta, expressa a complexidade da visão sistêmica do transporte rodoviário. A eficiência energética e as emissões desse setor dependem de aspectos tão variados como:

- Características dos veículos, como tipo e porte; tecnologia empregada; deterioração de seus sistemas em função de sua idade, de sua quilometragem acumulada e de sua manutenção; e ainda da introdução de modificações indevidas visando, por exemplo, ganhos de desempenho (ex. a quebra do lacre de bombas injetoras de caminhões). Convém aqui também lembrar que a tecnologia dos motores de combustão está intimamente correlacionada com o desenvolvimento dos combustíveis, tanto no que diz respeito à evolução de suas formulações para viabilizar novos sistemas de pós-tratamento e reduzir as emissões poluentes, como para viabilizar o uso de combustíveis alternativos.

- Composição da frota, em função, por exemplo, da menor ou maior participação de motociclos, automóveis, ônibus, veículos urbanos de carga (VUCs) e caminhões pesados.

- Condição de operação, como tipo de via, tipo e condição do piso; presença de curvas e rampas; da condição de tráfego; da altitude e das condições climáticas; dos fatores de carga médios dos transportes coletivos e de carga; do comportamento do motorista; etc.

- Logística empregada, envolvendo desde a seleção do tipo de veículo ou modal mais adequado para o tipo de demanda (ex. transporte coletivo de passageiros versus transporte individual; transporte rodoviário versus ferroviário), até a seleção de rotas e horários.

De maneira geral, as linhas de ação que vem sendo propostas para o aperfeiçoamento da eficiência energética e a mitigação das emissões do transporte rodoviário podem ser resumidas ao uso de novos combustíveis, sobretudo os renováveis, e aos aprimoramentos da tecnologia veicular, da logística e da infraestrutura viária.

Levando em conta esses aspectos e os objetivos deste trabalho, foi realizada uma revisão cujo resultado foi organizado sob os seguintes tópicos a seguir apresentados: a relação entre o consumo de combustíveis e as emissões de gases de efeito estufa e de poluentes tóxicos veiculares; caracterização e perspectivas evolutivas dos combustíveis, da tecnologia veicular e dos sistemas de transportes. 
Essas informações foram posteriormente utilizadas para desenvolver a ferramenta e as avaliações, objetivos da tese, ressalvado os limites impostos pela disponibilidade de dados que as consubstanciassem. Convém destacar que essas matérias estão passando por um acelerado processo evolutivo nestes últimos anos.

Sempre que julgado pertinente para facilitar a compreensão do trabalho, foram mantidas neste documento, depois de claramente identificadas, as abreviações derivadas das bibliografias existentes em inglês, por serem estas as mais comumente utilizadas pela comunidade técnica associada aos temas do trabalho e as mais fáceis de serem localizadas na bibliografia internacional disponível.

\subsection{A relação entre o consumo de combustíveis e as emissões de gases de efeito estufa e de poluentes tóxicos veiculares}

Para estabelecer, com base no conhecimento atual, o vínculo entre consumo de combustíveis e emissão de gases de efeito estufa (GEE) e de gases tóxicos veiculares, convém iniciar revendo os GEE antropogênicos selecionados pelo Painel Intergovernamental sobre Mudanças Climáticas (IPCC, sigla em inglês), como metas de redução do Protocolo de Quioto e das discussões dele derivadas ora em curso. São eles: dióxido de carbono $\left(\mathrm{CO}_{2}\right)$; metano $\left(\mathrm{CH}_{4}\right)$; óxido nitroso $\left(\mathrm{N}_{2} \mathrm{O}\right)$; hexafluoreto de enxofre $\left(\mathrm{SF}_{6}\right)$; hidrofluorcarbonetos (HFC) e perfluorcarbonetos (PFC). Existem outros. Alguns contemplados por outros acordos e regulamentos, como o tetrafluormetano ${ }^{1}\left(\mathrm{CF}_{4}\right)$ e os clorofluorcarbonetos $(\mathrm{CFC})$, cobertos pelo Protocolo de Montreal, e alguns ainda não regulamentados como GEE, como o trifluoreto de nitrogênio $\left(\mathrm{NF}_{3}\right)$, empregado pela indústria eletrônica.

Em volume, certamente a emissão veicular de GEE mais significativa é a de $\mathrm{CO}_{2}$, diretamente proporcional ao consumo de combustíveis fósseis e, por este motivo, tomado como referência para os demais GEE. O fator de emissão da gasolina e do óleo diesel, derivado de suas relações estequiométricas, é aproximadamente 3,2, ou seja, para cada kg queimado desses combustíveis gera-se cerca de $3,2 \mathrm{~kg}$ de $\mathrm{CO}_{2}$. O IPCC também recomenda que sejam consideradas as emissões veiculares $\mathrm{CH}_{4}$ e $\mathrm{N}_{2} \mathrm{O}$. Isso porque, apesar dos relativamente baixos volumes emitidos, conforme consta no "2007 IPCC AR4 WG1 Report" (2007), o $\mathrm{CH}_{4}$ e o $\mathrm{N}_{2} \mathrm{O}$

\footnotetext{
${ }^{1}$ Conhecido comercialmente por Freon-14.
} 
apresentam potenciais de aquecimento global (GWP, sigla em inglês) ${ }^{2}$, para um intervalo de tempo de 100 anos, respectivamente, de 25 e 298.

A emissão veicular de $\mathrm{CH}_{4}$ advém da combustão incompleta de hidrocarbonetos superiores ou ainda por ser o principal composto do gás natural, combustível fóssil de importância e consumo crescentes. Essa emissão é muitas vezes controlada pelas legislações de poluentes tóxicos, como o PROCONVE, justamente para subtraí-la dos hidrocarbonetos totais, em função desse gás em baixas concentrações não ser tóxico. Na prática, a medição em veículos nos países desenvolvidos resultou nos números expressos na Tabela 2.1 a seguir. Entretanto, dado existirem conversões irregulares e inadequadas no Brasil, é possível que o fator de emissão aqui seja superior ao valor do guia do IPCC.

As principais fontes antropogênicas de $\mathrm{CH}_{4}$, além das emissões fugitivas na produção e transporte do petróleo e do gás natural, são: minas de carvão; depósitos de lixo; redes de coleta e tratamento de esgotos; agricultura e produção animal. A favor do $\mathrm{CH}_{4}$ tem-se que muitas das medidas utilizadas para controlar sua emissão são custo-efetivas, seja por seu valor econômico como combustível ou pela existência do Mecanismo de Desenvolvimento Limpo (MDL). Segundo os critérios estabelecidos pelo IPCC, a emissão fugitiva que ocorre durante o processo de produção e distribuição do gás natural ou biogás é considerado separadamente da emissão de GEE devida ao uso desses combustíveis no transporte.

$\mathrm{O} \mathrm{N} \mathrm{N}_{2} \mathrm{O}$ é um dos óxidos de nitrogênio $\left(\mathrm{NO}_{\mathrm{X}}\right)$ formados a partir da reação do oxigênio com o nitrogênio presentes na atmosfera, quando submetidos à alta temperatura durante o processo de combustão nos motores. No que tange a seu efeito na saúde, o $\mathrm{N}_{2} \mathrm{O}$ na forma gasosa e em baixas concentrações é utilizado inclusive para fins medicinais como analgésico ou anestésico, ou ainda como gás hilariante ${ }^{3}$. Como o $\mathrm{NO}_{\mathrm{X}}$ é predominantemente composto por óxido nítrico (NO) e dióxido de nitrogênio $\left(\mathrm{NO}_{2}\right)$, antes das regulamentações da emissão de GEE veicular, a emissão de $\mathrm{N}_{2} \mathrm{O}$ não era usualmente medida. Como no caso do $\mathrm{CH}_{4}$, a medição de $\mathrm{N}_{2} \mathrm{O}$ em veículos, nos países desenvolvidos, resultou nos números expressos na Tabela 2.1.

A emissão antropogênica de $\mathrm{N}_{2} \mathrm{O}$ é principalmente associada à agroindústria, devido ao uso de fertilizantes nitrogenados e à biodegradação de dejetos da produção animal, e também à produção de nylon, material que é utilizado pela indústria automobilística. Mais uma vez,

\footnotetext{
${ }^{2}$ GWP é uma medida da contribuição do referido gás para o efeito estufa em relação ao $\mathrm{CO}_{2}$, em um determinado intervalo de tempo (o GWP do $\mathrm{CO}_{2}$ é igual a 1).

${ }^{3}$ Para maiores informações vide <http://www.inchem.org/documents/icsc/icsc/eics0067.htm>.
} 
segundo os critérios estabelecidos pelo IPCC, a emissão de $\mathrm{N}_{2} \mathrm{O}$ devida ao uso do nylon e de fertilizantes nitrogenados para a produção dos biocombustíveis é considerada, separadamente da emissão de GEE devida ao uso de energia em transporte.

Para ter-se uma noção da contribuição das emissões veiculares desses dois gases para o efeito estufa, a partir dos fatores de emissão (FE) anteriormente mencionados, obtidos no "2006 IPCC Guidelines for National Greenhouse Gas Inventories" (2006), e os correspondentes GWPs, gerou-se a Tabela 2.1.

Tabela 2.1 - Contribuições das emissões veiculares de $\mathrm{CH}_{4}$ e $\mathrm{N}_{2} \mathrm{O}$ ao efeito estufa.

\begin{tabular}{|c|c|c|c|c|c|c|c|c|c|}
\hline \multirow[b]{2}{*}{ Combustível } & \multirow{2}{*}{$\begin{array}{l}\text { Tecnologia } \\
\text { de controle } \\
\text { de emissões }\end{array}$} & \multirow{2}{*}{$\begin{array}{c}\mathrm{CO}_{2} \\
\mathrm{FE}_{\mathrm{CO} 2} \\
(\mathrm{~kg} / \mathrm{TJ})\end{array}$} & \multicolumn{3}{|c|}{$\mathrm{CH}_{4}$} & \multicolumn{3}{|c|}{$\mathrm{N}_{2} \mathrm{O}$} & \multirow{2}{*}{$\begin{array}{c}\mathrm{CH}_{4}+\mathrm{N}_{2} \mathrm{O} \\
\begin{array}{c}\text { Contrib. } \\
\text { relat. }\end{array}\end{array}$} \\
\hline & & & $\begin{array}{l}\mathrm{FE}_{\mathrm{CH} 4} \\
(\mathrm{~kg} / \mathrm{TJ})\end{array}$ & $\begin{array}{c}\text { x GWP } \\
\left(\mathrm{kg}_{\mathrm{CO} 2 \mathrm{e}} / \mathrm{TJ}\right)\end{array}$ & $\begin{array}{c}\text { Contrib. } \\
\text { relat. }\end{array}$ & $\begin{array}{l}\mathrm{FE}_{\mathrm{N} 2 \mathrm{O}} \\
(\mathrm{kg} / \mathrm{TJ})\end{array}$ & $\begin{array}{c}\text { x GWP } \\
\left(\mathrm{kg}_{\mathrm{CO} 2 \mathrm{e}} / \mathrm{TJ}\right)\end{array}$ & $\begin{array}{c}\text { Contrib. } \\
\text { relat. }\end{array}$ & \\
\hline \multirow[t]{3}{*}{ Gasolina } & $\begin{array}{c}\text { sem } \\
\text { controle }\end{array}$ & 69.300 & 33 & 825 & $1,2 \%$ & 3,2 & 954 & $1,3 \%$ & $2,5 \%$ \\
\hline & $\begin{array}{l}\text { catalisador } \\
\text { oxidação }\end{array}$ & 69.300 & 25 & 625 & $0,9 \%$ & 8,0 & 2384 & $3,3 \%$ & $4,2 \%$ \\
\hline & $\begin{array}{c}\text { leves }>1995 \\
\text { baixa } \mathrm{km}\end{array}$ & 69.300 & 3,8 & 95 & $0,1 \%$ & 5,7 & 1699 & $2,4 \%$ & $2,5 \%$ \\
\hline Diesel & --- & 74.100 & 4,0 & 98 & $0,1 \%$ & 3,9 & 1162 & $1,5 \%$ & $1,7 \%$ \\
\hline Gás natural & --- & 56.100 & 92 & 2.300 & $3,9 \%$ & 3,0 & 894 & $1,5 \%$ & $5,4 \%$ \\
\hline GLP & --- & 63.100 & 62 & 1.550 & $2,4 \%$ & 0,2 & 60 & $0,1 \%$ & $2,5 \%$ \\
\hline
\end{tabular}

Fonte: Cálculos realizados pelo autor a partir de dados do "2006 IPCC Guidelines for National GHG Inventories"

Com base nesses dados é possível concluir que, para os veículos atuais, as contribuições relativas do $\mathrm{CH}_{4}$ e do $\mathrm{N}_{2} \mathrm{O}$ na emissão de $\mathrm{GEE}$ veiculares são de, respectivamente, $0,1 \%$ e $2,4 \%$, que somadas totalizam cerca de $2,5 \%$. Porém, no caso de veículos movidos a gás natural, a contribuição relativa do $\mathrm{CH}_{4}$ pode chegar a 3,9\% do total, e em veículos movidos à gasolina dotados de catalisador de oxidação, a contribuição do $\mathrm{N}_{2} \mathrm{O}$ pode chegar a $3,3 \%$ do total.

Além do $\mathrm{CO}_{2}, \mathrm{CH}_{4}$ e $\mathrm{N}_{2} \mathrm{O}$, algumas emissões regulamentadas por sua toxidade são também identificadas por seu impacto no clima. Esse é o caso do monóxido de carbono $(\mathrm{CO})$ e do $\mathrm{NO}_{\mathrm{X}}$, classificados como GEE indiretos, por ocasionarem a formação secundária de $\mathrm{CO}_{2}$ e $\mathrm{N}_{2} \mathrm{O}$ na atmosfera, ou seja, serem precursores dos GEE. Além disso, $\mathrm{CO}, \mathrm{CH}_{4}$, compostos orgânicos voláteis não metano $(\mathrm{COVNM})$ e $\mathrm{NO}_{\mathrm{X}}$ são precursores do ozônio $\left(\mathrm{O}_{3}\right)$ troposférico. $\mathrm{O}$ ozônio, além de ser um dos principais componentes do "smog" fotoquímico, um dos principais poluentes dos grandes centros urbanos, é considerado, em função das concentrações observadas, o terceiro mais importante contribuinte antropogênico ao efeito estufa no hemisfério norte, atrás do $\mathrm{CO}_{2}$ e do $\mathrm{CH}_{4}$ (UNEP/WMO, 2011). 
Já a influência do material particulado (MP), uma das mais significativas emissões veiculares, sobretudo de veículos diesel, no efeito estufa é uma questão muito mais complexa. Apesar de ser identificado como um dos poluentes veiculares mais nocivos à saúde, sua contribuição à mudança climática é ainda controversa e precisa ser mais bem avaliada e entendida.

Alguns trabalhos recentes sugerem que um dos componentes do MP, o carbono negro (BC, sigla em inglês) troposférico é o segundo mais significativo poluente antropogênico causador de mudanças climáticas (UCSD, 2008; RAMANA, 2010). Isso se deve a dois diferentes fenômenos.

O primeiro decorre da deposição do $\mathrm{BC}$ sobre as superfícies, o que em geral ocasiona a redução do Albedo nessas áreas, sobretudo, quando essa deposição ocorre sobre a neve e o gelo. Já sua deposição sobre o solo, se por um lado pode impactar negativamente sobre o Albedo, por outro contribui positivamente para a fertilidade do mesmo (GLASER, 2001).

A avaliação da segunda contribuição do BC à mudança climática é igualmente complexa. Segundo Bond (2009), o BC contido no MP é um potente transformador de luz em calor. Com base em estudos e dados de terceiros, inclusive do IPCC, o Conselho Internacional de Transporte Limpo (ICCT, sigla em inglês) (2009) concluiu, segundo eles conservadoramente, que o GWP para 100 anos do BC é 460, valor significativamente superior aos GWPs do $\mathrm{CH}_{4} \mathrm{e}$ do $\mathrm{N}_{2} \mathrm{O}$. No entanto, é necessário também considerar:

- Transporte é somente uma das possíveis fontes. BC pode advir, além de motores de combustão, também de instalações industriais e da queima da biomassa, inclusive queimadas, fornos e fogões à lenha, práticas ainda largamente empregadas no Brasil.

- De acordo com Johnson, o MP emitido pelos motores é constituído predominantemente por material carbonáceo misturado à água e hidrocarbonetos líquidos ${ }^{4}$, provenientes do combustível e do óleo lubrificante (JONHSON, 2005). Porém, disperso na atmosfera, em poucas horas ele se transforma em uma partícula muito mais complexa composta por, além dos elementos já mencionados, sulfatos, principalmente de amônio, nitratos, ácidos orgânicos e outros compostos inorgânicos ( $\mathrm{Cu}, \mathrm{Si}, \mathrm{K}$ entre eles). Entretanto, exceto o BC, todos os demais componentes do MP refletem a luz e, consequentemente, têm GWPs

\footnotetext{
${ }^{4}$ A quantidade de sulfetos presentes no MP recém-emitido depende do teor de enxofre do óleo diesel, condição que varia significativamente em função do combustível utilizado no local.
} 
negativos (BOND, 2009) ${ }^{5}$. Além disso, o MP tem uma vida relativamente curta na atmosfera. Logo, esse balanço depende não somente da qualidade do combustível e da tecnologia veicular empregada ${ }^{6}$, como também da parcela de contribuição de outras fontes e das condições geográficas e atmosféricas que afetam a transformação e a dispersão do MP na atmosfera.

Ou seja, para estabelecer-se o impacto do MP veicular sobre o clima é necessário levar em conta aspectos como a constituição e distribuição da frota automotiva, o tipo de cobertura do terreno existente (ex. gelo, cobertura vegetal, etc.); a localização e o porte das fontes não veiculares; o regime de chuvas e a direção predominante dos ventos em cada região; a relação BC/HC; etc. Logo, trata-se de mecanismo bastante complexo, que este trabalho não se propõe a aferir. Avaliações dessa natureza começam a ser realizadas (SHINDELL, 2011; UNEP/WMO 2011), porém não foi identificada nenhuma feita especificamente para o Brasil.

Caso a influência do BC no efeito estufa venha a ser considerada, ela implicará em consequências práticas significativas. Por exemplo, segundo Walsh (2009), a menor emissão de GEE do motor ciclo Diesel, solução adotada pela Comunidade Europeia, só se sustenta se este dispuser de sistema de pós-tratamento que reduza significativamente a emissão de MP. Caso contrário, a emissão de BC praticamente neutraliza a vantagem que o motor ciclo Diesel apresenta em função de seu menor consumo.

Pode-se concluir que o controle das emissões veiculares tóxicas, imposto pelas legislações correlacionadas, proporciona ganhos tanto no que tange à saúde pública, à produção agrícola e à preservação do meio ambiente como também contribui positivamente para questão climática ao mitigar a emissão de MP, de precursores do ozônio, e de $\mathrm{CH}_{4}$ e $\mathrm{N}_{2} \mathrm{O}$. Como muitos desses compostos apresentam vida relativamente curta na atmosfera, esse controle é uma medida importante para refrear a mudança climática no curto prazo, enquanto que, dada a grande estabilidade do $\mathrm{CO}_{2}$ na atmosfera, a redução do consumo dos combustíveis veiculares é importante para proteger o clima no longo prazo.

Apesar da emissão energética de GEE veicular ser predominantemente decorrente da combustão, o guia do IPCC recomenda que ainda sejam consideradas as contribuições de

\footnotetext{
5 Esse é o caso, por exemplo, do dióxido de enxofre $\left(\mathrm{SO}_{2}\right)$, produto da oxidação do enxofre contido nos combustíveis. Apesar disso, é importante retirar o enxofre dos combustíveis para mitigar os efeitos deletérios do $\mathrm{SO}_{2}$ na atmosfera e para viabilizar os sistemas de pós-tratamento utilizados para o controle de outros poluentes.

6 À medida que a tecnologia veicular evolui, não somente a emissão de MP vem sendo significativamente reduzida, assim como a participação relativa do BC no MP é cada vez menor.
} 
emissões evaporativas dos combustíveis e da degradação da ureia, quando é utilizada solução aquosa desta em sistemas de pós-tratamento via sua pulverização nos gases de escapamento ${ }^{7}$.

Emissões dos demais GEE do Protocolo de Quioto, isto é, $\mathrm{SF}_{6}, \mathrm{HFC}$ e PFC, não são gases normalmente emitidos por veículos. Seu vínculo com o setor automotivo é indireto, enquanto gases utilizados em sistemas de ar-condicionado ou pela indústria eletroeletrônica, itens cada vez mais presentes nos veículos. Eventualmente, podem ocorrer, por exemplo, emissões fugitivas de gases utilizados por aparelhos de ar condicionado dos veículos, em função de uma manutenção efetuada inadequadamente ou como consequência de um acidente. Por seu grande impacto no efeito estufa, com GWPs de algumas centenas a dezenas de milhares de vezes superiores ao do $\mathrm{CO}_{2}$, o IPCC considera essas emissões, porém separadamente do capítulo que trata da emissão de GEE associada ao uso da energia no transporte e, por esse motivo, não serão consideradas neste trabalho.

\subsection{Caracterização e perspectivas evolutivas dos combustíveis, da tecnologia veicular e do setor de transportes}

Para rever-se o contexto e as alternativas para fazer frente à questão do transporte rodoviário, eles foram agrupados sob os temas: combustíveis, tecnologia veicular e o setor de transportes, que serão detalhados abaixo.

\subsubsection{Combustíveis}

É necessário inicialmente destacar que, segundo o Fórum Econômico Mundial (WEF, sigla em inglês) (2011), petróleo ainda responde por cerca de 96\% dos combustíveis consumidos pelo setor de transportes. Considerando toda a infraestrutura industrial existente para a produção, estocagem e distribuição desses combustíveis, uma total ruptura em curto prazo do modelo atual é na prática impossível. Além disso, os atuais motores de combustão e os veículos que os utilizam são o resultado de mais de um século de evolução realizado em paralelo com esses combustíveis. Consequentemente, novas alternativas de transporte, exceto se por algum evento inesperado, somente se viabilizarão técnico-economicamente se implantadas progressivamente e com o maior reaproveitamento possível dessa infraestrutura e tecnologia.

\footnotetext{
${ }^{7}$ Tipicamente esses sistemas são denominados SCRs, as iniciais de "selective catalyst converter". A emissão de $\mathrm{N}_{2} \mathrm{O}$ de veículos com sistemas de pós-tratamento desse tipo pode ser ligeiramente aumentada.
} 


\subsubsection{Projeções do mercado de combustíveis veiculares}

Uma das mais significativas projeções do mercado internacional de combustíveis é aquela realizada sistematicamente pela Agência Internacional de Energia (IEA, sigla em inglês), órgão vinculado à Organização para a Cooperação e Desenvolvimento Econômico (OECD, sigla em inglês). Destaque-se que esta agência, apesar de inicialmente focada na questão energética, tem dado igual importância ao tema da mudança climática. É apresentado abaixo um resumo das principais conclusões de seus recentes anuários "Panorama Energético Mundial” (WEO, sigla em inglês) e publicações correlatas.

No WEO 2011 (IEA, 2011), a IEA relata que, apesar das recentes dificuldades financeiras mundiais terem ocasionando a redução do consumo de energia global em anos anteriores, em 2011 ela voltou a crescer 5\%, o que foi acompanhado por um novo recorde na emissão de $\mathrm{CO}_{2}$. Apesar dos esforços de muitos governos para aumentar a eficiência energética, a intensidade energética mundial cresceu pelo segundo ano consecutivo.

Para realizar suas projeções, a IEA considera, entre outros aspectos, quatro possíveis cenários em função da maior ou menor atuação dos governos para a implantação de novas políticas associadas à questão climática: "políticas atuais"; "novas políticas"; "450"; e o "mundo eficiente". O primeiro cenário corresponde àquele que nenhuma nova política seja implantada além daquelas existentes no ano do estudo. O segundo, considerado o mais provável, supõe que, além das medidas já existentes, sejam adotadas novas políticas, porém em um ritmo conservador. $\mathrm{O}$ terceiro pressupõe uma maior a agressividade na adoção de novas políticas, visando que a concentração de $\mathrm{CO}_{2}$ na atmosfera não ultrapasse 450 ppm, o que supostamente restringiria o aumento de temperatura média global a $2^{\circ} \mathrm{C}$. E o último, visando avaliar o resultado de aprimorar a eficiência energética por todas as vias que tenham senso econômico, pressupõe a adoção de todas as políticas que eliminem barreiras de mercado e de todas as medidas economicamente viáveis que aprimorem a eficiência energética. Como cada cenário gera resultados significativamente diferentes, a IEA destaca a importância do papel dos governos na definição de nosso futuro energético.

Já no WEO 2011, a IEA alerta que a janela do "cenário 450" está se fechando, e que retardar as medidas para restringir a emissão de GEE é uma falsa economia porque para cada US\$ 1 não gasto antes de 2020 para mitigar essa emissão demandará US\$ 4,3 após 2020 para adaptar-se aos efeitos da mudança climática. As medidas para incrementar a eficiência energética previstas no cenário "nova políticas" é uma significativa evolução em relação às das décadas 
anteriores, mas ainda assim elas são insuficientes. Esta agência está se referindo principalmente aos regulamentos que estabelecem metas e critérios objetivos para restringir a emissão de GEE que vêm sendo adotados pelos países desenvolvidos ${ }^{8}$.

No cenário "novas políticas", a IEA estima que de 2010 a 2035, supondo a retomada do crescimento global médio econômico de 3,5\% ao ano e da população de 1,7 bilhão, a demanda de energia cresça em um terço. Esse crescimento será devido, sobretudo, a países não-OECD. Em 2035, apesar do consumo per capita chinês ainda ser menos da metade do estadunidense, a China possivelmente consumirá $70 \%$ mais energia que os EUA. Além desse, os maiores crescimentos do consumo de energia devem ocorrer na Índia, Indonésia, Brasil e Oriente Médio. Para tanto, serão necessários investimentos da ordem de US\$ 35 trilhões (base 2010), dois terços de países não-OECD, US\$ 20 trilhões em óleo e gás, e grande parte do restante na geração, transmissão e distribuição de energia elétrica.

Como declarado por esta agência em 2011, a rigorosa análise quantitativa das tendências energéticas e climáticas de longo prazo, indica que o atual caminho, agravado pelo acidente nuclear de Fukushima e pelos conflitos que vem ocorrendo em países do Oriente Médio e Norte da África (MENA, sigla em inglês), coloca em risco o fornecimento de energia. Este quadro é ainda piorado pela crise financeira internacional, que tem desviado a atenção e restringido os meios de intervenção dos governos sobre as questões energéticas e ambientais, inclusive para alcançar-se um acordo global quanto à emissão de GEE. Essa constatação, devida inclusive à redução dos investimentos na indústria do petróleo e no desenvolvimento de fontes renováveis, já havia sido relatada nos WEO anteriores (IEA, 2009, 2010). O relativo insucesso das recentes reuniões da Convenção Quadro das Nações Unidas Sobre Mudança do Clima (UNFCCC, sigla em inglês) para estabelecer novas metas internacionais de redução da emissão de GEE é provavelmente uma manifestação dessa conjuntura desfavorável.

Por outro lado, a IEA declara no WEO 2012 (2012) que as mudanças que vem ocorrendo no panorama energético mundial são de tal magnitude que está ficando difícil prever os potenciais impactos que elas causarão nesse mercado. Segundo esse relatório, as mudanças mais significativas são: o recuo da energia atômica; a crescente participação de fontes renováveis na geração elétrica, principalmente hidráulica, eólica e solar; e principalmente a ampliação da produção de gás de fontes não convencionais, sobretudo nos Estados Unidos. Esta produção

\footnotetext{
${ }^{8}$ No Brasil já existem algumas metas globais e prescrições específicas para alguns setores, como o Inovar-Auto.
} 
nos EUA resultou na redução do preço do gás natural e do uso de carvão no mercado interno, o qual está sendo agora exportado para a Europa. Mantidas as atuais tendências, o IEA prevê que os Estados Unidos se tornem o maior produtor de petróleo nos anos 2020 e exportador de derivados a partir dos 2030, transferindo o foco da segurança energética para o eixo Oriente Médio-Ásia.

A esperada revitalização da produção de petróleo iraquiano e a difusão e implantação de medidas para promover a eficiência energética também são apontados como possíveis causas para uma "mudança de jogo".

Entretanto, a IEA ressalta nesse relatório que essas mudanças não colocarão o sistema energético global em um caminho sustentável, sendo mantida a previsão que em longo prazo a temperatura média global, no cenário "novas políticas", aumentará 3,6 ${ }^{\circ} \mathrm{C}$. Um importante aspecto destacado por essa agência é a dificuldade de reduzir-se o consumo de energia diante do fato que ainda existe cerca de 1,3 bilhão de pessoas sem acesso nem mesmo à eletricidade.

Sob o ponto de vista dos objetivos deste trabalho, os prognósticos mais significativos da IEA são:

A demanda por combustíveis fósseis continuará a crescer, apesar de sua participação relativa na matriz energética mundial decrescerá de $81 \%$ em 2010 para $75 \%$ em 2035.

A participação do setor de transportes, que hoje já responde por cerca de metade desse consumo, continuará crescendo. As reduções de consumo veicular hoje promovidas pelos EUA e a Comunidade Europeia não serão suficientes para compensar o crescimento da frota de automóveis em países não-OECD, que deve ultrapassar o número de automóveis vendidos em países OECD em 2020, e principalmente o crescimento do transporte de cargas que hoje responde por quase $40 \%$ do aumento da demanda de petróleo, sobretudo de óleo diesel. Este último crescimento é agravado pela maior dificuldade de se adotar medidas visando à redução do consumo dos caminhões.

Ela destaca ainda que esse crescimento da demanda de combustíveis fósseis é mantido, em parte, por subsídios promovidos pelos governos, sobretudo de países do MENA. O montante desses subsídios em 2011 estima-se foi de US\$ 523 bilhões, cerca de seis vezes superior aos subsídios recebidos por fontes renováveis.

Consequentemente, estima-se que o consumo cresça dos 87,4 milhões de barris por dia (Mb/dia) em 2011 para 99.7 Mb/dia em 2035, e o preço do barril de petróleo, hoje estabilizado 
pela crise financeira e pelo retorno da Líbia ao mercado, eleve-se a US\$125 (base 2011) em $2035^{9}$.

Em termos globais, a importação de petróleo crescerá dos aproximadamente $50 \%$ atuais para cerca de $80 \%$ em 2035, o que tornará a segurança energética ainda mais crítica e sensível a questões geopolíticas. Consequentemente, a volatilidade do preço continuará a existir. Os principais fornecedores continuarão a serem alguns poucos países da região do MENA. Como os investimentos necessários em "upstream" nessa região estão abaixo daqueles requeridos pelo cenário "novas políticas", há o risco que o preço do barril se eleve a curto prazo.

Por outro lado, a produção de petróleo convencional deve manter-se nos próximos anos e declinar futuramente, atingindo a aproximadamente $68 \mathrm{Mb} / \mathrm{dia}$ em 2035 . O volume adicional requerido deverá ser suprido por derivados líquidos do gás natural e por fontes não convencionais, respectivamente, $18 \mathrm{Mb} / \mathrm{dia}$ e $10 \mathrm{Mb} / \mathrm{dia}$ em 2035. O maior crescimento da produção de petróleo previsto deve ocorrer no Iraque, Arábia Saudita, Brasil, Cazaquistão e Canadá. Biocombustíveis subsidiados deverão prover o equivalente a mais de $4 \mathrm{Mb} / \mathrm{dia}^{11}$.

As perspectivas de crescimento da oferta e da demanda de gás natural são bastante favoráveis, em qualquer um dos cenários considerados, a ponto da IEA (2011) sugerir uma futura possível "era do ouro" do gás. A favor desse combustível tem-se que suas reservas estão dispersas geograficamente, o que é propício sob o ponto de vista da segurança energética, e do gás ser, entre os combustíveis fósseis, o potencialmente mais limpo, tanto quanto à emissão de GEE entre os combustíveis fósseis, como de poluentes tóxicos. No entanto, para que isso de fato ocorra é necessário que a indústria do gás estabeleça padrões de produção e distribuição mais rigorosos que os atuais.

Cerca de metade das reservas atuais de gás provem de fontes não convencionais de metano, de maior custo de exploração, como reservatórios pouco porosos e pouco permeáveis ("tight gas"), reservatórios profundos, gás de folhelho, metano de leito de carvão (CBM, sigla em inglês), e hidratos de metano ${ }^{12}$. No entanto, algumas dessas fontes são vistas com ressalvas sob o ponto de vista ambiental, dado apresentarem maior risco de liberação do gás na atmosfera.

\footnotetext{
${ }^{9} \mathrm{O}$ valor nominal em 2035 prevê-se seja US\$ 215 por barril.

${ }^{10}$ Atividades de exploração, desenvolvimento, produção e transporte para beneficiamento.

${ }^{11}$ Esse volume deve demandar US\$ 1,4 trilhão de subsídios.

${ }^{12}$ Que ocorrem, principalmente, na região da tundra ou "permafrost".
} 
No que tange aos biocombustíveis, o extraordinário crescimento que ocorreu em 2007 (37\%), puxado principalmente pelos países da OECD, recuou não somente pela queda do preço do petróleo, mas também porque os governos desses países reduziram suas metas de misturas de biocombustíveis, face ao impacto negativo que eles possivelmente causaram nos preços dos alimentos e aos questionamentos sobre seus reais benefícios para reduzir a emissão de GEE. Apesar do atual recuo, a IEA prevê que, no longo prazo, os biocombustíveis retomarão seu crescimento, devendo sua produção evoluir dos atuais cerca de $0,9 \mathrm{Mb} / \mathrm{dia}$ para aproximadamente $4 \mathrm{Mb}$ /dia em 2030, que corresponde a um crescimento de sua participação na demanda mundial de combustíveis veiculares dos atuais cerca de $2 \%$ para aproximadamente $5 \%$. Para que essa previsão se realize, a IEA considera que os biocombustíveis de segunda geração atingirão sua viabilidade econômica.

Resumidamente, apesar dos riscos de eventuais interrupções de fornecimento em função das instabilidades políticas e regionais e da emissão de GEE, os combustíveis derivados de petróleo devem continuar a dominar o cenário dos transportes. De qualquer forma, essas duas questões têm sido fortes incentivadores para o desenvolvimento de novos combustíveis, que serão revistos no item 2.2.1.3 adiante.

Se confirmadas as atuais expectativas de crescimento da produção de gás natural e de biocombustíveis, e do início da produção de petróleo do Pré-sal, expressas no Plano Nacional de Energia 2030 (BRASIL 2007), isso supostamente deixará o Brasil em uma situação relativamente confortável no futuro contexto internacional.

\subsubsection{Comparando a emissão de $\mathrm{CO}_{2}$ dos principais combustíveis veiculares}

Como já discutido anteriormente no item 2.1, considerando que, em volume, certamente a emissão veicular de GEE mais significativa é a de $\mathrm{CO}_{2}$, convém iniciar essa avaliação revendose as propriedades físico-químicas pertinentes desses combustíveis e sua condição de uso. Posteriormente, também será considerada a análise do ciclo de vida ${ }^{13}$ (ACV) desses combustíveis.

Convém destacar que esses combustíveis são, em geral, misturas de diferentes compostos químicos e, consequentemente, dependendo de sua origem, composição, estado e da fonte da

\footnotetext{
${ }^{13}$ Muitas vezes é também utilizado o termo "avaliação do ciclo de vida", mais coerente com o termo em inglês que lhe deu origem. Segundo a Associação Brasileira de Ciclo de Vida (ABCV) ambos são conceitualmente corretos. Mas devido sua maior difusão, a ABCV preferiu adotar o termo "análise do ciclo de vida".
} 
informação, suas propriedades podem apresentar variações, que serão tanto maiores quanto maiores as variações da composição dos combustíveis. Entre esses, o que apresenta maior variação de composição é o gás natural.

Como já mencionado, da relação estequiométrica dos combustíveis obtêm-se seus fatores de emissão de $\mathrm{CO}_{2}\left(\mathrm{FE}_{\mathrm{CO} 2}\right)$, expressos, por exemplo, em kg de $\mathrm{CO}_{2}$ por kg de combustível. Da equação de combustão dos combustíveis típicos, disponíveis no Brasil e no exterior, chega-se aos $\mathrm{FE}_{\mathrm{CO} 2}$ mostrados na segunda coluna da Tabela 2.2.

Tabela 2.2 - Emissão de $\mathrm{CO}_{2}$ devida às propriedades físico-químicas dos combustíveis veiculares.

\begin{tabular}{cccc}
\hline Combustível & $\begin{array}{c}\text { Fator de emissão } \\
{\left[\mathrm{kg}_{\mathrm{CO} 2} / \mathrm{kg}_{\text {comb. }}\right]}\end{array}$ & $\begin{array}{c}\text { Poder Calorífico } \\
\text { Inferior } \\
{\left[\mathrm{MJ} / \mathrm{kg}_{\mathrm{comb}}\right]}\end{array}$ & $\begin{array}{c}\text { Emissão de CO } \\
{\left[\mathrm{g}_{\mathrm{CO} 2} / \mathrm{MJ}\right]}\end{array}$ \\
\hline gás natural $^{(1)}$ & 2,75 & 48,8 & 56,3 \\
etanol hidratado $^{(2)}$ & 1,75 & 24,6 & 71,4 \\
gasolina C $^{(3)}$ & 2,88 & 40,0 & 72,0 \\
gasolina A $^{\text {biodiesel }}{ }^{(4)}$ & 3,18 & 44,0 & 72,2 \\
óleo diesel & 2,83 & 37,9 & 74,7 \\
\hline
\end{tabular}

Notas: Os valores acima foram calculados para:

(1) A composição típica do gás distribuído na Região Sudeste do Brasil.

(2) Etanol hidratado carburante (EHC) contendo 93,2\% em massa de etanol.

(3) Teor de etanol anidro de $22 \%$ em volume, valor utilizado para o desenvolvimento dos veículos.

(4) Biodiesel puro, em geral identificado como B100.

Fonte: Cálculos realizados pelo autor a partir de dados do "USDOE Energy Efficiency and Renewable Energy" e do artigo SAE 973038 "Efeito da composição do gás natural no desempenho de motor de ônibus".

Em princípio, esses fatores de emissão de $\mathrm{CO}_{2}$ indicariam uma significativa vantagem para o etanol hidratado. Porém, ao considerar-se a energia contida nesses combustíveis, expressa por seus poderes caloríficos inferiores apresentados nessa mesma tabela, derivam-se as emissões de $\mathrm{CO}_{2}$ por unidade de energia química neles contida. Com as mesmas ressalvas relativas à variação da composição dos combustíveis, estes últimos indicariam uma grande vantagem para o uso do gás natural. Convém lembrar que a ACV ainda não foi considerada.

Entretanto, é preciso também considerar a eficiência de conversão da energia química do combustível na energia mecânica necessária para mover os veículos, questão que mais uma vez mostra o vínculo entre os combustíveis e a tecnologia veicular empregada.

É possível obter-se valores de rendimentos térmico, volumétrico e mecânico, de motores de combustão operando com esses combustíveis, sobretudo em condições estacionárias de carga e 
rotação. No entanto, é praticamente impossível ter-se esses rendimentos para todas as condições de utilização do motor, envolvendo tipicamente cargas parciais e regimes transientes. No lugar desses rendimentos, e sem prejuízo de exatidão, para efeito comparativo, foi utilizada neste trabalho a grandeza intitulada eficiência de conversão relativa que é a relação inversa dos consumos energéticos de veículos similares, operando com os diferentes combustíveis, para realizar o mesmo trabalho. Essas relações de consumo energético são obtidas a partir dos consumos de combustíveis volumétricos, obtidos em condições análogas, por exemplo, medidos conforme ciclos padrão, multiplicados por seus correspondentes conteúdos energéticos. Foi tomado como referência veículos operando com gasolina A (sem etanol), não disponível no mercado nacional.

Exemplificando, para percorrer, por exemplo, o ciclo de homologação FTP 75, um veículo otimizado para gasolina A consome " $\mathrm{x}$ " litros. Esse mesmo veículo, com motor similar, porém agora otimizado para etanol consome " $y$ " litros. Convertendo esses consumos volumétricos para consumos energéticos, é possível inferir, para o referido veículo, com qual combustível ele operou mais eficientemente para realizar o mesmo trabalho.

Não é difícil obter dados de consumo dessa natureza, mas por outro lado não é fácil assegurar que esses dados sejam de veículos rigorosamente correspondentes, cada um com motores otimizados para cada um dos combustíveis. É preciso avaliar com cuidado dados de veículos "flex" para este fim. Com a atual tecnologia empregada, os motores desses veículos são uma solução de compromisso entre os combustíveis possíveis de serem empregados. Se há indícios que seu desenvolvimento privilegiou um dos combustíveis, convém que os dados desse veículo com o outro combustível não sejam utilizados para essa comparação.

Com base em dados recentes, são apresentadas na Tabela 2.3: as relações de consumo volumétrico típicas em referência à gasolina A (obtidas, por exemplo, a partir do consumo em litros por $100 \mathrm{~km}$ ); o conteúdo energético volumétrico; a eficiência de conversão relativa e a taxa de emissão de $\mathrm{CO}_{2}$ relativa.

Não se pretende aqui que as razões de consumo apresentadas nessa tabela sejam tomadas como definitivas, devendo-se aprimorá-los caso se obtenham dados que melhor representem uma determinada realidade. Por exemplo, a relação de consumos do GNV apresentada a seguir, obtida a partir de dados de um veículo leve, é significativamente diferente daquela que ocorre em veículos pesados. 
Tabela 2.3 - Taxa de emissão de $\mathrm{CO}_{2}$ relativa desconsiderando WTT da ACV.

\begin{tabular}{|c|c|c|c|c|c|}
\hline \multirow{2}{*}{ Combustível $^{(1)}$} & \multicolumn{2}{|c|}{ Relação de consumos } & \multirow{2}{*}{$\begin{array}{l}\text { Densidade } \\
\text { de energia } \\
\text { [MJ / litro] }\end{array}$} & \multirow{2}{*}{$\begin{array}{c}\eta_{\text {conv relativa }} \\
{[\%]}\end{array}$} & \multirow{2}{*}{$\begin{array}{c}\boldsymbol{E}_{\mathrm{CO} 2 \mathrm{f}} \\
{[\%]}\end{array}$} \\
\hline & {$[\Delta \% 1 / 100 \mathrm{~km}]$} & {$[\Delta \% \mathrm{~km} / \mathrm{l}]$} & & & \\
\hline gás natural & $105^{(2)}$ & 95 & $36,0^{(3)}$ & 95 & 82 \\
\hline óleo diesel & 75 & 133 & 35,8 & 121 & 86 \\
\hline biodiesel & 81 & 124 & 33,3 & 121 & 86 \\
\hline etanol hidratado & 150 & 67 & 19,9 & 109 & 91 \\
\hline gasolina $\mathrm{C}$ & 104 & 96 & 29,9 & 104 & 96 \\
\hline gasolina $\mathrm{A}$ & 100 & 100 & 32,4 & 100 & 100 \\
\hline
\end{tabular}

Notas: (1) Para os mesmos combustíveis considerados na tabela anterior.

(2) A conversão do consumo de GNV em $\mathrm{Nm}^{3}$ para litro de gasolina A foi feita com base na equivalência de seus conteúdos energéticos, procedimento adotado pela USEPA, resultando em 1 litro equivalente de gasolina A igual a 0,909 $\mathrm{Nm}^{3}$ de GNV (“1 equivalent gallon = 121,5 cubic feet").

(3) Expresso em $\mathrm{MJ} / \mathrm{Nm}^{3}$.

Fonte: Estimativas realizadas pelo autor a partir dos dados apresentados na Tabela 2.2, das tabelas de consumo e eficiência energética do Programa Brasileiro de Etiquetagem e do "Fuel Economy Guide" da USEPA.

A eficiência de conversão relativa é calculada pela Equação 2.1.

$$
\eta_{\text {conv.relativa }}=\frac{\text { Consumo }_{\text {gasolinaA }} \times D E_{\text {gasolinaA }}}{\text { Consumo }_{f} \times D E_{f}}=\frac{\text { Cons }_{\text {gasolinaA }}}{\text { Cons }_{f}}
$$

onde $\eta_{\text {conv.relativa }}$ é a eficiência de conversão relativa.

Consumo $_{f}$ é o consumo do combustível $f$ (ex. gasolina C), em 1/100 km ${ }^{14}$.

$D E_{, f} \quad$ é a densidade de energia do combustível $f$, em $\mathrm{MJ} / \mathrm{l}$.

Cons $_{f} \quad$ é o consumo energético do combustível $f$, em MJ.

E a partir da eficiência de conversão relativa, é possível obter a taxa de emissão de $\mathrm{CO}_{2}$ relativa, calculada pela Equação 2.2, para cada um dos combustíveis.

$$
E_{\text {CO2 relativa }}=\frac{E_{C O 2 f}}{\eta_{\text {conv.relativa }} \times E_{\text {CO2gasolina } A}}
$$

onde $E_{\text {CO2relativa }}$ é a taxa de emissão de $\mathrm{CO}_{2}$ relativa.

$E_{\mathrm{CO} 2 f}$ é a emissão de $\mathrm{CO}_{2}$ por unidade de energia do combustível $f$, em $\mathrm{g}_{\mathrm{CO} 2} / \mathrm{MJ}$.

No entanto, até o momento esse resultado expressa somente a parcela do "tanque à roda" (TTW, sigla em inglês) do ciclo de vida dos combustíveis. Ao considerar-se a parcela do "poço

\footnotetext{
${ }^{14}$ Outras unidades podem ser utilizadas desde que elas sejam coerentes com a densidade de energia e entre os dois lados da fração.
} 
ao tanque" (WTT, sigla em inglês) da ACV, que leva em conta a produção e distribuição dos combustíveis, essa relação entre os combustíveis pode mudar significativamente.

Apesar de já ter evoluído bastante, ainda há muita discussão e controvérsia sobre a parcela WTT da ACV dos combustíveis. Essas análises são sempre muito complexas porque envolvem a avaliação de diversos aspectos não uniformes. Isso ocorre tanto para os combustíveis fósseis como para os biocombustíveis. A penalidade em termos de GEE para a extração de petróleo ou gás natural em regiões de mais difícil acesso ou distantes dos centros consumidores (ex. Mar do Norte, Alasca ou Pré-sal) será maior do que aqueles sem essas dificuldades. Da mesma forma, a penalidade para a produção de biocombustíveis depende da espécie vegetal utilizada (por exemplo, cana de açúcar, milho, beterraba para produzir etanol, ou soja, gordura animal, canola, etc. para produzir biodiesel) assim como de diversos outros aspectos como distância dos centros consumidores, demanda por fertilizantes nitrogenados, colheita mecanizada, consumo de combustíveis fósseis, etc.

Enquanto se discute quais os principais aspectos que tem que ser levados em consideração nessas análises, dependendo das premissas assumidas, é natural que esses estudos tipicamente não cheguem aos mesmos resultados e algumas vezes apresentem significativas divergências. Somente para ilustrar esse fato, é mostrada na Ilustração 2.1 uma compilação de resultados da ACV para a produção de etanol realizada em 2008 pela IEA e o UNEP para a OECD.

No estudo divulgado pela UNICAMP e Coopersucar em 2003, considerando diversos aspectos pertinentes, como consumo de combustível fóssil, uso de fertilizantes, etc., mas desconsiderando mudanças de uso da terra, que serão discutidas adiante, resultou, no pior cenário do contexto brasileiro, em uma emissão líquida de GEE em relação aos combustíveis fósseis de cerca de 19\% (MACEDO, 2003). De agora em diante neste texto, a esta relação será denominada emissão líquida relativa.

A complexidade desses estudos foi recentemente agravada pela ainda mais complicada discussão sobre as mudanças de uso da terra (LUC, sigla em inglês), que trata de questões como o carbono retido no solo, e mudanças indiretas de uso da terra (ILUC, sigla em inglês), que trata de questões como a migração de culturas para outras regiões, por exemplo, a Amazônia, como muitas vezes se alega. A consideração da mudança do uso da terra pode levar a resultados completamente diversos daqueles sem ela. Isso pode ser visto na Ilustração 2.2, que mostra o resultado de estudo realizado pela USEPA em 2008 para levantamento das emissões líquidas relativas de diversos biocombustíveis. 


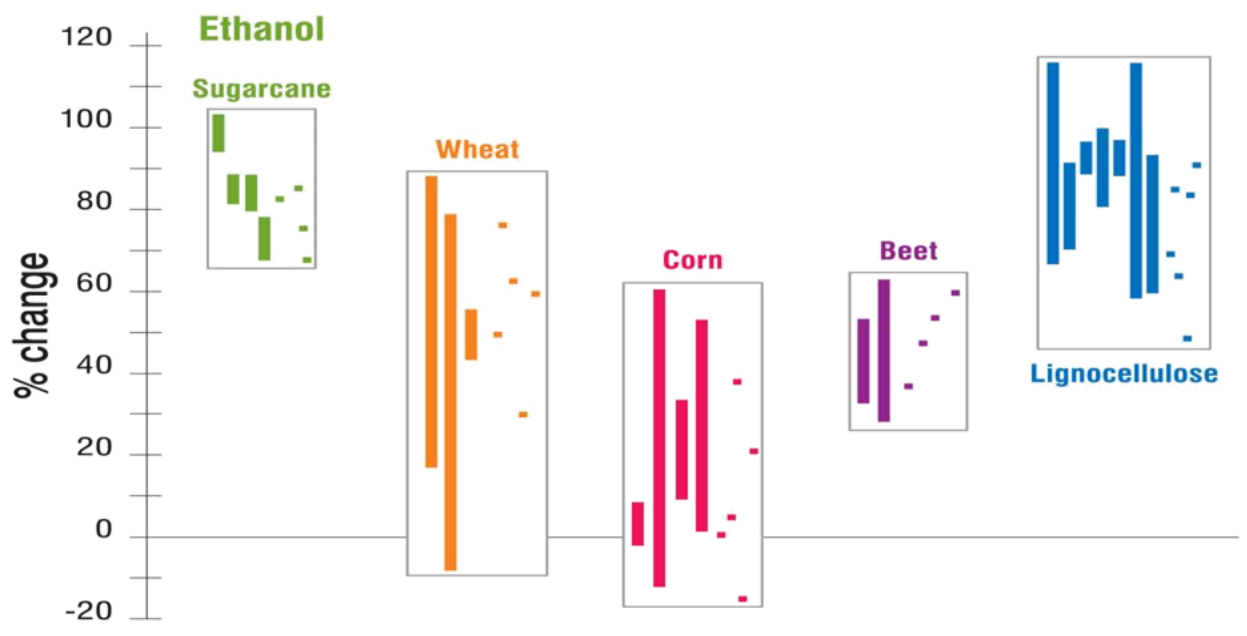

Ilustração 2.1 - Diferenças entre os benefícios na redução da emissão de GEE proporcionado pelo etanol como substituto da gasolina, observadas em diferentes ACV, sem LUC.

Fonte: Figura 2, pg. 17, de "From 1st- to 2nd-generation biofuels technologies - An overview of current industry and RD\&D activities", publicado em 2008 pela a IEA e o UNEP para a OECD.

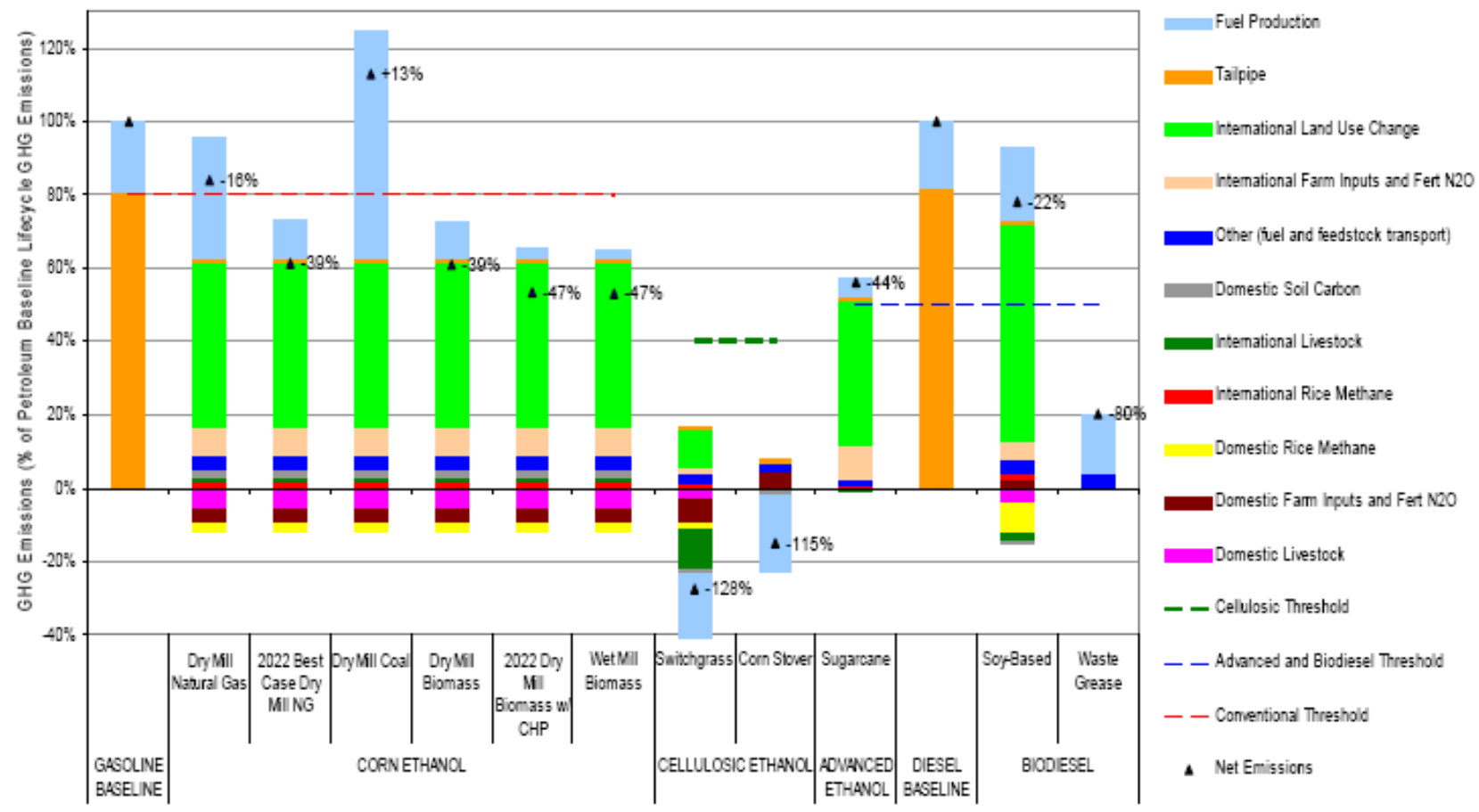

Ilustração 2.2 - Resultados da ACV de GEE de biocombustíveis tomando a gasolina como referência, segundo estudo da USEPA.

Fonte: Ilustração 2, p. 17, de "Discussion Draft of Environmental Protection Agency Regulatory Impact Analysis", publicado pela USEPA em 2009 para 100 anos a uma taxa de desconto de $2 \%$ aa.

Nesse gráfico é possível observar que, levando em consideração a ILUC levantada por essa agência, o balanço de GEE do etanol de milho chega a ser, no pior cenário, desfavorável e do biodiesel de soja teria uma emissão líquida relativa de cerca de $78 \%$. 
Um marco da evolução dessas análises é o fato de que, após a divulgação desse estudo, a argumentação técnica do governo e do setor sucroalcooleiro brasileiro levou a USEPA a reavaliar o caso do etanol de cana brasileiro e atribuir-lhe em 2010 a categoria de biocombustível avançado, em função do reconhecimento que mesmo com o ILUC, este apresenta uma emissão líquida relativa de somente $39 \%$.

Não é objetivo deste trabalho entrar nessa discussão, mas somente mostrar suas implicações. Isso será ilustrado por meio do recálculo da taxa de emissão de $\mathrm{CO}_{2}$ relativa para os três cenários hipotéticos da parcela WTT apresentados na Tabela 2.4, baseados nas emissões líquidas relativas dos biocombustíveis sugeridos pelo IPCC, por fontes brasileiras sem LUC e pelo estudo da USEPA sem LUC (biodiesel) e com ILUC.

Tabela 2.4 - Cenários hipotéticos sobre as emissões líquidas relativas de GEE da parcela WTT dos biocombustíveis brasileiros.

\begin{tabular}{cccc}
\hline \multirow{2}{*}{ Combustível } & \multicolumn{2}{c}{ Emissão líquida relativa de GEE das parcelas WTT } \\
\cline { 2 - 4 } & IPCC $^{(1)}$ & Sem LUC & Com ILUC \\
\hline etanol hidratado & $0 \%$ & $15 \%$ & $39 \%^{(2)}$ \\
biodiesel & $0 \%$ & $26 \%{ }^{(2)}$ & $78 \%^{(2)}$ \\
\hline
\end{tabular}

Notas: (1) Segundo o critério do IPCC, a emissão de GEE dos biocombustíveis é nula, exceto pelas pequenas contribuições das emissões de $\mathrm{CH}_{4}$ e $\mathrm{N}_{2} \mathrm{O}$. As emissões para suas produções são contabilizadas em outros setores que não o da energia em transportes.

(2) Segundo estudo da USEPA.

Fonte: Estimativas realizadas pelo autor com base no "2006 IPCC Guidelines for National Greenhouse Gas Inventories", no estudo divulgado em 2003 pela UNICAMP e Coopersucar e nos valores observados na Ilustração 2.2 anterior.

Utilizando esses valores, resulta nas taxas de emissão de $\mathrm{CO}_{2}$ relativas apresentadas na Tabela 2.5. Aplicando o critério do IPCC, exceto pela contribuição das emissões de $\mathrm{CH}_{4}$ e $\mathrm{N}_{2} \mathrm{O}$, etanol e biodiesel apresentariam taxas de emissão relativa de $\mathrm{CO}_{2}$ praticamente nulas. Nos demais cenários considerando o WTT, os ganhos dos biocombustíveis são bastantes significativos mesmo considerando a ILUC. Já quanto à gasolina C, no cenário sem LUC seu resultado é ligeiramente pior que o GNV e melhor que o óleo diesel, e no cenário com ILUC ligeiramente pior que o óleo diesel. 
Tabela 2.5 - Taxas de emissão de $\mathrm{CO}_{2}$ relativa em \% considerando ou não WTT da ACV.

\begin{tabular}{ccccc}
\hline \multirow{2}{*}{ Combustível } & \multicolumn{5}{c}{ Cenários } \\
\cline { 2 - 5 } & IPCC & Sem LUC & Com ILUC & TTW \\
\hline etanol hidratado & 0 & 14 & 35 & 91 \\
biodiesel & 0 & 22 & 67 & 86 \\
gasolina C & 81 & 83 & 87 & 96 \\
gás natural & 82 & 82 & 82 & 82 \\
óleo diesel & 86 & 86 & 86 & 86 \\
gasolina A & 100 & 100 & 100 & 100 \\
\hline
\end{tabular}

Fonte: Estimativas realizadas pelo autor com base nos dados das Tabelas 2.3 e 2.4.

Deste tópico podem-se extrair algumas conclusões em relação ao o que está sendo proposto para o mercado nacional. Isto é, para os valores considerados nesse cálculo, válidos para veículos leves, o uso de veículos leves a diesel no Brasil não traria ganhos significativos sob o ponto de vista da emissão de GEE, nem mesmo quando confrontado com a gasolina $\mathrm{C}$ brasileira. Ao contrário, possivelmente trará algum prejuízo. Quanto ao uso do GNV, dependendo da emissão líquida relativa do etanol de cana, ele poderia chegar a trazer uma pequena vantagem em relação à gasolina $\mathrm{C}$, mas ainda ocasionaria algo da ordem do dobro da emissão de GEE quando comparado ao etanol hidratado, mesmo no cenário mais desfavorável a este último combustível. Entretanto, não se deve deixar de levar em consideração também as correspondentes emissões tóxicas que podem ser pontos favoráveis ou desfavoráveis a esses combustíveis.

Segundo estudo da IEA (2010), visando à redução da emissão de GEE, ao comparar-se o custo incremental de diferentes combustíveis alternativos, o etanol de cana é, em princípio, também o mais custo efetivo, como pode ser observado na Ilustração 2.3.

\subsubsection{O desenvolvimento de combustíveis mais limpos}

As atuais perspectivas de produção e demanda dos combustíveis convencionais e os novos requisitos ambientais têm impulsionado a pesquisa e o desenvolvimento de novos combustíveis. Existem inúmeras iniciativas visando promover diferentes soluções, não somente de combustíveis renováveis, mas também dos derivados do petróleo convencional e de outras fontes fósseis não convencionais. 


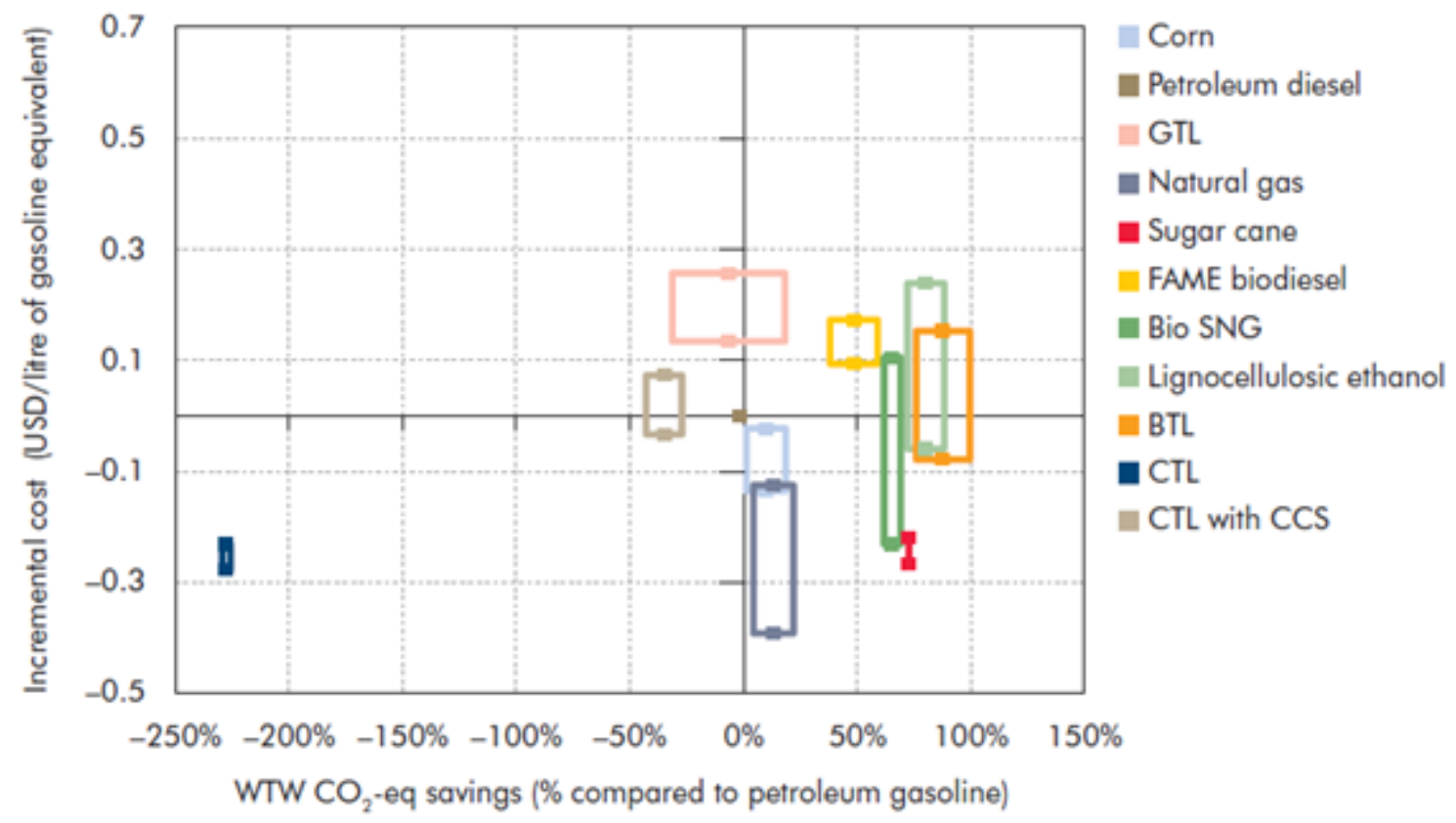

Nota: Redução negativa de $\mathrm{CO}_{2}$-eq significa que o uso do combustível considerado implica, na verdade, no aumento da emissão de GEE em relação à gasolina.

Ilustração 2.3 - Custo incremental de combustíveis alternativos em função de seus potenciais de redução de emissão de GEE em relação a gasolina, ao custo de petróleo de US\$ 120 por barril, segundo a IEA.

Fonte: Ilustração 7.18, pg. 280, de "Energy Technologies Perspectives - Scenarios \& strategies to 2050", publicado pela IEA em 2010.

\subsection{Combustíveis fósseis}

Com relação aos derivados de petróleo, além dos desenvolvimentos que vêm sendo feitos por força de lei, como por exemplo, a redução do teor de enxofre, convém citar que existem iniciativas como a do Laboratório Nacional de Energia Renovável estadunidense (NREL, sigla em inglês) que constituiu um grupo de trabalho denominado Combustíveis Avançados Baseados em Petróleo (APBF, sigla em inglês). A proposta do APFB é avaliar, em parceria com a indústria automobilística, como aprimorar as especificações dos combustíveis convencionais e de suas misturas para, em conjunto com a tecnologia veicular atual, melhor responder aos novos quesitos ambientais ${ }^{15}$.

Apesar de não se prever seu esgotamento nos próximos anos, o aumento do valor do petróleo convencional e as questões associadas à segurança energética vêm viabilizando a utilização de outras fontes de combustíveis fósseis não convencionais. Pertencem a esse grupo os combustíveis gasosos e líquidos derivados de gás natural (ex. metanol, dimetil éter (DME) e

\footnotetext{
${ }^{15}$ Maiores informações podem ser obtidas em http://www.nrel.gov/vehiclesandfuels/apbf/
} 
diesel Fischer-Tropsch); os combustíveis líquidos sintéticos derivados do carvão (CTL, sigla em inglês), e óleo extraído de rochas (folhelho ou xisto) e areias betuminosas.

Entretanto, o desenvolvimento dessas alternativas não está limitado somente por sua economicidade. Em geral, elas também causam grandes impactos ambientais, seja local (liberação de compostos tóxicos e metais pesados, e grande consumo de água) ou ainda, devido o maior consumo energético para sua extração ou processamento, aumentam significativamente a emissão de GEE, mesmo em relação ao petróleo. Apesar das críticas que vem recebendo ${ }^{16}$, o óleo de areias betuminosas das grandes reservas canadenses já é hoje uma importante fonte de óleo na América do Norte.

\section{Gás natural}

Em função das grandes reservas existentes na Bacia de Santos e no Pré-sal, a Petrobras está estimando que a produção de gás natural (GN) tenha um crescimento de $15 \%$ ao ano no período de 2010 a 2015 e de $10 \%$ nos anos subsequentes até 2020. Isso está ocorrendo em uma ocasião onde há uma grande oferta de GN no mercado internacional, o que reduz as vantagens para exportá-lo (SANTOS, 2010).

É natural, portanto, que existam iniciativas visando promover seu consumo interno, inclusive para retomar seu ora declinante uso veicular. Esse é o caso do recente Decreto ${ }^{\circ} 56.074$, de 9 de agosto de 2010, de São Paulo, que instituiu o Programa Paulista de Petróleo e Gás Natural que, entre outros, tem por objetivo promover o uso do GN em ônibus urbanos. Apesar da potencial vantagem econômica que o gás natural veicular (GNV) poderá apresentar em um futuro próximo em relação aos demais combustíveis veiculares, é necessário lembrar que o incentivo a seu uso já foi objeto de outras iniciativas governamentais mal sucedidas.

Por meio das leis municipais $n^{\circ} 10.950$ de 1991 e no 12.140 de 1996, o Governo do Município São Paulo, motivado por razões ambientais, já decretou a obrigatoriedade da substituição da frota de ônibus a diesel por ônibus a GNV. Entretanto, as diversas dificuldades, inclusive de caráter técnico-econômico, que ocorreram naquela ocasião, acabaram por gerar uma grande resistência dos frotistas ao GNV, o que levou ao insucesso dessa iniciativa. Em 2005, visando estabelecer um incentivo financeiro ao uso do GNV como substituto do óleo diesel, a Petrobras anunciou seu compromisso de manter o preço do GNV para frotistas a 55\% do valor do óleo

\footnotetext{
${ }^{16}$ Vide http://www.guardian.co.uk/environment/2012/feb/20/canada-eu-tar-sands.
} 
diesel por um prazo de 10 anos. No entanto, essa nova iniciativa foi interrompida pela restrição de fornecimento imposta pela Bolívia em 2006.

Para melhor entender as dificuldades do GNV para substituir o óleo diesel, convém rever alguns aspectos técnicos. Essa revisão também servirá para ilustrar adequadamente como o sucesso de um combustível está intimamente correlacionado com a tecnologia veicular empregada.

O GN é constituído predominantemente por metano. Ao contrário do propano e do butano, principais constituintes do gás liquefeito de petróleo (GLP), o gás natural não se liquefaz facilmente, motivo pelo qual seu transporte e distribuição são feitos, sobretudo, via gasodutos a pressões relativamente baixas. Em função da forma como é feita sua distribuição e como é muito difícil estocá-lo em grandes volumes, as primeiras questões a serem consideradas para o uso veicular do GN são: disponibilidade local e garantia de continuidade de seu fornecimento.

Outro aspecto importante para o uso veicular do GN é que, para se obter uma autonomia aceitável, é necessário que sua densidade energética de armazenamento seja significativamente aumentada. Motivo pelo qual ele é usualmente comprimido (GNC) a alta pressão, tipicamente de 20 a $25 \mathrm{MPa}$ (aproximadamente de 200 a 250 atmosferas), ou liquefeito (GNL), após resfriado e mantido à temperatura inferior a $-162{ }^{\circ} \mathrm{C}$ (criogenia). Para reduzir a evaporação do GNL é usual também comprimi-lo, porém a pressões mais baixas de 0,1 a 1,7 MPa (de 1 a 17 atmosferas). Como esse processo demanda equipamentos de custo elevado e consome muita energia, o GNL é normalmente empregado somente quando é necessário transportar o gás natural por via marítima. O uso veicular do GNL, caso ele esteja disponível, pode apresentar algumas vantagens em relação ao GNC. É ainda possível armazená-lo adsorvidos em materiais micro porosos, tecnologia esta ainda não competitiva.

De qualquer forma, é fácil concluir que qualquer uma dessas alternativas exige reservatórios especiais, de maior peso, de maior custo e, de maneira geral, com formatos nem sempre convenientes para seu uso veicular, sobretudo em automóveis. Outra consequência prática associada às condições de seu armazenamento é a maior dificuldade de seu abastecimento, que exige instalações especiais, como por exemplo, estações de compressão, além de ser as vezes mais lento, o que implica em custos operacionais mais elevados para os frotistas.

A outra característica físico-química do GNV, que no atual contexto tecnológico, determina um segundo conjunto de implicações práticas, é sua elevada resistência à autoignição. Tanto que para ele foi criada uma escala específica, denominada número metano, que conceitualmente é 
semelhante à octanagem. Essa propriedade faz do GNV um combustível adequado para motores ciclo Otto.

No entanto, além de metano, o gás natural coletado nos poços contém também pequenas parcelas de etano, butano, propano, nitrogênio $\left(\mathrm{N}_{2}\right)$ e $\mathrm{CO}_{2}$. Em condições normais, por apresentarem maiores conteúdos energéticos e, consequentemente, valores econômicos, o butano e o propano são usualmente segregados do gás natural. Comparados ao metano, esses gases têm menor resistência à autoignição. Em função disso, no início da implantação do GNV no Brasil, por falhas em Unidades de Processamento de Gás Natural (UPGNs), aconteceram alguns episódios do gás ter sido distribuído com maiores teores de butano ou propano. A consequência desse fato foi à ocorrência de pré-ignição e, consequentemente, danos nos motores de combustão de maiores dimensões, justamente os de maior custo.

$\mathrm{O} \mathrm{N}_{2}$ e $\mathrm{CO}_{2}$ são gases inertes que sob o ponto de vista operacional reduzem o conteúdo energético do GNV e, consequentemente, agravam às questões associadas ao armazenamento do combustível e ao ajuste dos motores. Obviamente a eventual liberação do $\mathrm{CO}_{2}$ contido no GN tem que ser contabilizada no balanço de emissão de GEE desse combustível.

A maior resistência à autoignição possibilita que um motor ajustado para GNV utilize taxas de compressão mais elevadas e, por conseguinte, obtenha ganhos de rendimento energético em relação à gasolina e ao etanol. Porém, na prática, essa potencial vantagem do GNV não vem sendo utilizada ou porque os veículos são convertidos utilizando "kits" com tecnologia ou ajustes piores do que aqueles originais do veículo, ou porque os veículos são configurados para serem bi ou tri-combustível (ex. GNV e gasolina e/ou etanol), que implica em uma solução de compromisso, em geral, sacrificando a condição de operação ideal com GNV. Isso ocorre mesmo nos "kits" de GNV oferecidos pela indústria automobilística brasileira para os veículos "flex"17.

Já quando comparado a um motor ciclo Diesel, o rendimento térmico de um motor a GNV ciclo Otto é em geral inferior, principalmente devido ao significativo menor rendimento dos motores ciclo Otto em cargas parciais. Esse fato, somado ao maior peso dos reservatórios de GNV, implicam em uma desvantagem expressiva de consumo dos veículos a GNV em relação a seus equivalentes a diesel.

\footnotetext{
${ }^{17}$ Essas soluções são identificadas por suas marcas registradas "Triflex" e "Tetrafuel”.
} 
Além disso, o preço relativo para consumidor que vem sendo praticado para o GNV, a gasolina e o óleo diesel, fazem com que o uso do GNV seja muito mais difundido entre veículos leves do que pesados. A menor escala de produção de equipamentos para veículos pesados tende a encarecer seu custo inicial e de operação, o que realimenta essa tendência desfavorável ao uso do GNV nesses veículos ${ }^{18}$.

Contrapondo-se às desvantagens do GNV, sobretudo em relação ao diesel, por ser o GN um combustível gasoso constituído de moléculas relativamente pequenas e uniformes, sua queima é potencialmente muito mais limpa no tocante às emissões tóxicas, sobretudo quando se compara às emissões de MP de um motor diesel. Entretanto, para que essa vantagem de fato ocorra é necessário que a tecnologia empregada seja adequadamente desenvolvida. Muitas vezes, o uso de "kits" de conversão, sobretudo de geração tecnológica anterior ao sistema original do veículo que foi convertido, leva a um aumento das emissões ao invés de sua redução (VILLANUEVA, 2002).

O bom desempenho do GNV também é corroborado por resultados práticos. Na Califórnia, estado norte-americano que pratica a mais restritiva legislação de emissão tóxica existente, boa parte dos veículos classificados como "Super Ultra Low Emission Vehicle" (SULEV) pelo “California Air Resources Board" (CARB) são veículos a GNV ${ }^{19}$. Na Europa, os primeiros veículos a obter a classificação "Enhanced Environmentally Friendly Vehicle" (EEV) foram ônibus a GNV.

Com visto no item 2.2.1.2, no que diz respeito à emissão de GEE, o uso do GNV pode reduzir a emissão de $\mathrm{CO}_{2}$ em cerca de $20 \%$ em relação à gasolina sem etanol e apresentar alguma vantagem mesmo em relação ao diesel. No entanto, dependendo de resultados da análise do ciclo de vida, nem mesmo a vantagem do GNV em relação à gasolina se sustenta para a nossa gasolina C, que contém cerca de $22 \%$ de etanol.

Em veículos leves, a tecnologia dos motores a gás é muito semelhante aos demais motores do ciclo Otto (gasolina, etanol, “flex”). Tipicamente são motores que trabalham com sistemas de controle retroalimentados, operando com mistura estequiométrica e catalisadores de três vias. As soluções para veículos pesados são mais complexas porque usualmente esses veículos

\footnotetext{
18 Para maiores informações sobre aplicações de GNV em veículos pesados vide, por exemplo, <http://www.ngvc.org/> e < http://www.iangv.org/>, acessados em 12/08/2013.

${ }^{19}$ A lista dos veículos californianos mais "limpos", que entre outros, gozam do incentivo de poderem usar faixas exclusivas, pode ser obtida em http://www.arb.ca.gov/msprog/carpool/carpool.htm, acessado em 17/7/13.
} 
utilizam motores ciclo Diesel, os quais tem diferenças expressivas em relação a um motor ciclo Otto. A solução mais simples para converter um motor Diesel para GNV é adicionar a ele um sistema de injeção de GNV na admissão, tornando o motor duplo-combustível. A injeção de óleo diesel é mantida para operar como chama piloto. Entretanto, essa solução é limitada por uma série de compromissos que reduzem a parcela de diesel substituído, as vantagens ambientais do uso do gás, e a justificativa econômica para sua conversão. Apesar disso, em função de ser a solução de mais fácil implantação e da vantagem de ser uma solução reversível, faz com que muitos fabricantes continuem investindo na busca de um ponto de equilíbrio adequado entre esses compromissos.

As demais alternativas para veículos pesados implicam na conversão do motor para o ciclo Otto. Uma alternativa é ajustar o motor para trabalhar com excesso de ar, o que permite maximizar o aproveitamento dos componentes dos motores diesel e a obtenção de ganhos de eficiência energética. Por outro lado, o excesso de ar inviabiliza o uso de catalisadores de três vias, o que impede que esta solução seja utilizada quando há limites de emissões tóxicos mais restritivos.

A última alternativa, e a que apresenta os maiores benefícios ambientais, é o reprojeto do motor ciclo Diesel para motor ciclo Otto a gás estequiométrico, operacionalmente semelhante aos motores dos veículos leves a gás, equipados com sistemas de controle retroalimentados e catalisadores de três vias, solução adotada pelos fabricantes de ônibus europeus.

\subsection{Combustíveis renováveis}

No que tange a combustíveis renováveis, as iniciativas são ainda mais diversas, porque fortemente influenciadas por condições regionais específicas. Isso pode ser exemplificado pela parceria constituída na Comunidade Europeia para o desenvolvimento do projeto "Refuel", financiado pela Comissão Europeia para promover o uso de biocombustíveis na Europa (REFUEL PROJECT, 2008). Os combustíveis selecionados por esse projeto são: biodiesel derivado de canola, girassol e resíduos orgânicos; etanol de diversas outras fontes além da cana; diesel Fischer-Tropsch, bio-dimetil éter (bio-DME) e biogás sintético (bio-SNG, sigla em inglês), derivados de madeira e resíduos florestais e agrícolas.

Pesquisam-se também os alcoóis superiores (ex. butanol) cuja utilização veicular traz algumas vantagens em relação ao metanol e o etanol, e há ainda as pesquisas visando viabilizar o uso do hidrogênio, seja em motores de combustão ou em células a combustíveis. 
Entre as muitas alternativas existentes, obviamente os combustíveis renováveis mais importantes para o contexto brasileiro são, nessa ordem, o etanol e o biodiesel. Em função do potencial impacto que eles podem causar, convém também rever as atuais perspectivas dos biocombustíveis de segunda geração (por ex. diesel de cana), muitos dos quais, caso venham a se consolidar no mercado, fortalecerão ainda mais a indústria da cana. É feita a seguir uma breve revisão desses combustíveis.

\section{Etanol}

As principais propriedades físico-químicas do etanol que o tornam um combustível particularmente adequado para o uso em motores ciclo Otto são: a alta resistência à auto inflamação, expressa por sua elevada octanagem, e o maior calor latente de vaporização, que possibilita o resfriamento do ar de admissão e, consequentemente, o aumento do volume de mistura admitido. Outra vantagem do etanol é o fato dele ser uma substância pura, enquanto a gasolina é uma mistura de centenas de hidrocarbonetos com cadeias de 5 a 12 carbonos, o que possibilita, em motores dedicados, um melhor controle de sua queima e, consequentemente, uma combustão mais limpa.

Outra importante propriedade que condiciona o uso veicular do etanol é seu teor de oxigênio de aproximadamente $35 \%$ em massa, o que reduz seu poder calorífico em relação aos combustíveis veiculares tradicionais dessa mesma ordem e implica, de maneira geral, em um maior consumo volumétrico e em uma menor autonomia do veículo. Em motores ciclo Otto essa desvantagem pode ser parcialmente compensada pela maior eficiência energética possibilitada pela maior octanagem e maior calor latente de vaporização ${ }^{20}$. O mesmo não ocorre com relação ao motor ciclo Diesel, que na prática apresenta um melhor rendimento energético do que o motor ciclo Otto operando com gasolina ou etanol.

A atual relevância do etanol brasileiro é decorrente da soma de uma série de fatores favoráveis. Alguns estruturais, como sua evolução histórica, na qual se destaca a implantação do Programa do Álcool (Proálcool); o conhecimento tecnológico, porte e competitividade de nosso setor sucroalcooleiro; e a disponibilidade no país de terras agricultáveis e de clima propícios. Outros são mais conjunturais, como a existência de tecnologia veicular a custo competitivo para a utilização de misturas gasolina-etanol (ex. E10) ou de veículos "flex". E apesar não ter sido

\footnotetext{
${ }^{20}$ Existe um compromisso entre o enchimento e a menor relação ar-combustível do etanol.
} 
levado em conta por ocasião do Proálcool, passa a ser cada vez mais importante também o excelente desempenho do etanol brasileiro no que diz respeito à emissão de GEE, como já revisto no item 2.2.1.3. Apesar das atuais incertezas relacionadas à questão do uso da terra, o etanol de cana brasileiro é hoje mundialmente reconhecido como uma das melhores opções, para redução da emissão de $\mathrm{CO}_{2}$ do setor de transportes, tanto no que diz respeito a seu balanço energético e de emissão de GEE, quanto por sua economicidade. Consequentemente, o Brasil é, em geral, considerado como um potencial fornecedor de parte da crescente demanda internacional por etanol.

Esses fatos são corroborados, primeiro, pelos diversos programas de países ou blocos de países para misturar combustíveis renováveis aos combustíveis convencionais, sendo muitas vezes, especificamente de etanol à gasolina. Citando alguns programas significativos, têm-se: Estados Unidos, União Europeia, China, Índia, Japão, Canada, Austrália, Argentina e Colômbia. Alguns estabeleceram metas voluntárias, outros, metas compulsórias. Um resumo dos programas desses países pode ser visto na Tabela 2.6. De maneira geral, a grande maioria espera atingir sua meta em parte por meio da produção interna, mas quase inevitavelmente reconhecendo também a necessidade de recorrer à importação.

No entanto, boas perspectivas não são suficientes para garantir o sucesso do etanol brasileiro. Por exemplo, em trabalho divulgado pela USEPA (2010), apesar de que significativa parcela da exportação brasileira de etanol ser naquela ocasião realizada por meio de países do Caribe ${ }^{21}$, o governo federal dos EUA naturalmente já identificava o Brasil como um importante potencial fornecedor de etanol para o mercado estadunidense. Em função disso, esse trabalho da USEPA também avalia a capacidade brasileira para atender a nova demanda que seria criada.

\footnotetext{
21 Devido aos benefícios concedidos aos países caribenhos, por meio de um programa de apoio unilateral estadunidense denominado "Caribbean Basin Initiative". Para tanto, o etanol hidratado brasileiro é nesses países desidratado e reexportado, sobretudo, para os EUA. Com a queda do imposto ao produto brasileiro ao etanol, esse quadro está mudando.
} 
Tabela 2.6 - Programas internacionais prevendo o uso de biocombustíveis ou etanol.

\begin{tabular}{|c|c|c|c|c|c|}
\hline País & Tipo de & Meta & Demanda & $\begin{array}{c}\text { Produção } \\
\text { interna }\end{array}$ & Importação \\
\hline & & & \multicolumn{3}{|c|}{ em milhões de litros por ano } \\
\hline Argentina & biocombustível & $\begin{array}{l}\text { compulsória } \\
\text { E5 em } 2010\end{array}$ & $\begin{array}{c}270 \\
\text { em } 2010\end{array}$ & & \\
\hline Austrália & biocombustível & $\begin{array}{l}\text { voluntária } \\
\text { de } 2 \text { a } 5 \%\end{array}$ & $\begin{array}{c}352 \\
\text { em } 2010\end{array}$ & & \\
\hline Canada & $\begin{array}{c}\text { renovável } \\
\text { (predominante/ } \\
\text { etanol) }\end{array}$ & $\begin{array}{l}\text { compulsória } \\
5 \% \text { em } 2010 \\
\text { de E5 a E8,5 }\end{array}$ & $\begin{array}{c}>984 \\
\text { em } 2010\end{array}$ & & \\
\hline China & etanol & $\begin{array}{c}\text { compulsória } \\
\text { E10 }\end{array}$ & $\begin{array}{c}28.800 \\
\text { em } 2020\end{array}$ & $\begin{array}{c}12.500 \\
\text { em } 2020\end{array}$ & $\begin{array}{c}16.300 \\
\text { em } 2020\end{array}$ \\
\hline Colômbia & etanol & $\begin{array}{c}\text { compulsória } \\
\text { E10 em } 2008 \text { para } \\
\text { cidades >500 mil hab. }\end{array}$ & --- & --- & --- \\
\hline EUA & biocombustível & compulsória & $\begin{array}{c}\text { até } 136.000 \\
\text { em } 2022\end{array}$ & & \\
\hline Índia & $\begin{array}{l}\text { etanol e } \\
\text { biodiesel }\end{array}$ & $\begin{array}{l}\text { voluntária } \\
\text { E5 ou E10 }\end{array}$ & $\begin{array}{c}850 \text { a } 1.700 \\
\text { em } 2010\end{array}$ & $\begin{array}{c}\sim 1.500 \\
\text { em } 2010\end{array}$ & $\begin{array}{c}0 \text { a } 200 \\
\text { em } 2020\end{array}$ \\
\hline Japão & $\begin{array}{l}\text { etanol ou } \\
\text { ETBE }\end{array}$ & $\begin{array}{l}\text { compulsória } \\
\text { E3 ou ETBE7 a } 25\end{array}$ & $\sim 340$ a 380 & $\sim 100$ & $\begin{array}{c}\sim 40 \text { a } 6.000 \\
(1.000 \text { do BR })\end{array}$ \\
\hline $\begin{array}{l}\text { União } \\
\text { Europeia }\end{array}$ & $\begin{array}{l}\text { biocombustível } \\
\text { (biodiesel } \\
\text { e etanol) }\end{array}$ & $\begin{array}{c}\text { compulsória } \\
5,75 \% * \text { em } 2010 \\
10 \% * \text { em } 2020 \\
\text { *com base em energia }\end{array}$ & $\begin{array}{l}\sim 20.000 \\
\text { em } 2022\end{array}$ & $\begin{array}{c}\sim 6.000 \\
\text { em } 2022\end{array}$ & $\begin{array}{l}\sim 14.000 \\
\text { em } 2022\end{array}$ \\
\hline
\end{tabular}

Fonte: Quadro elaborado pelo autor com base nas informações constantes no "Renewable Fuel Standard Programs (RFS2) Regulatory Impact Analysis”, publicado pela USEPA em 2010.

Apesar de diversas projeções favoráveis realizadas por diferentes entidades sobre a evolução da capacidade brasileira de produção e de exportação que foram compiladas, mostradas nas Ilustrações 2.4 e 2.5, a USEPA questiona se o Brasil tem, de fato, condições de ampliar sua produção. Isso levando em consideração não somente o volume de investimento necessário, estimado da ordem de US\$ 2 bilhões a US\$ 4 bilhões por ano, como também questões como a habilidade do setor público para alavancar o aprimoramento da infraestrutura de transporte ${ }^{22}$, a realização de pesquisa e desenvolvimento e a formação de mão-de-obra. Entre outras coisas, esse trabalho cita, por exemplo, a baixa aptidão do país para formar engenheiros ${ }^{23}$.

\footnotetext{
${ }^{22}$ Segundo esse trabalho, $22 \%$ do preço do etanol brasileiro exportado são devidos ao custo do transporte, valor considerado muito elevado, em princípio, porque fortemente baseado em transporte rodoviário.

23 Segundo publicado pelo USEPA, o Brasil é capaz de formar somente oito engenheiros por 100.000 mil habitantes, enquanto os EUA forma 20, a União Europeia 33 e a Coreia 80.
} 


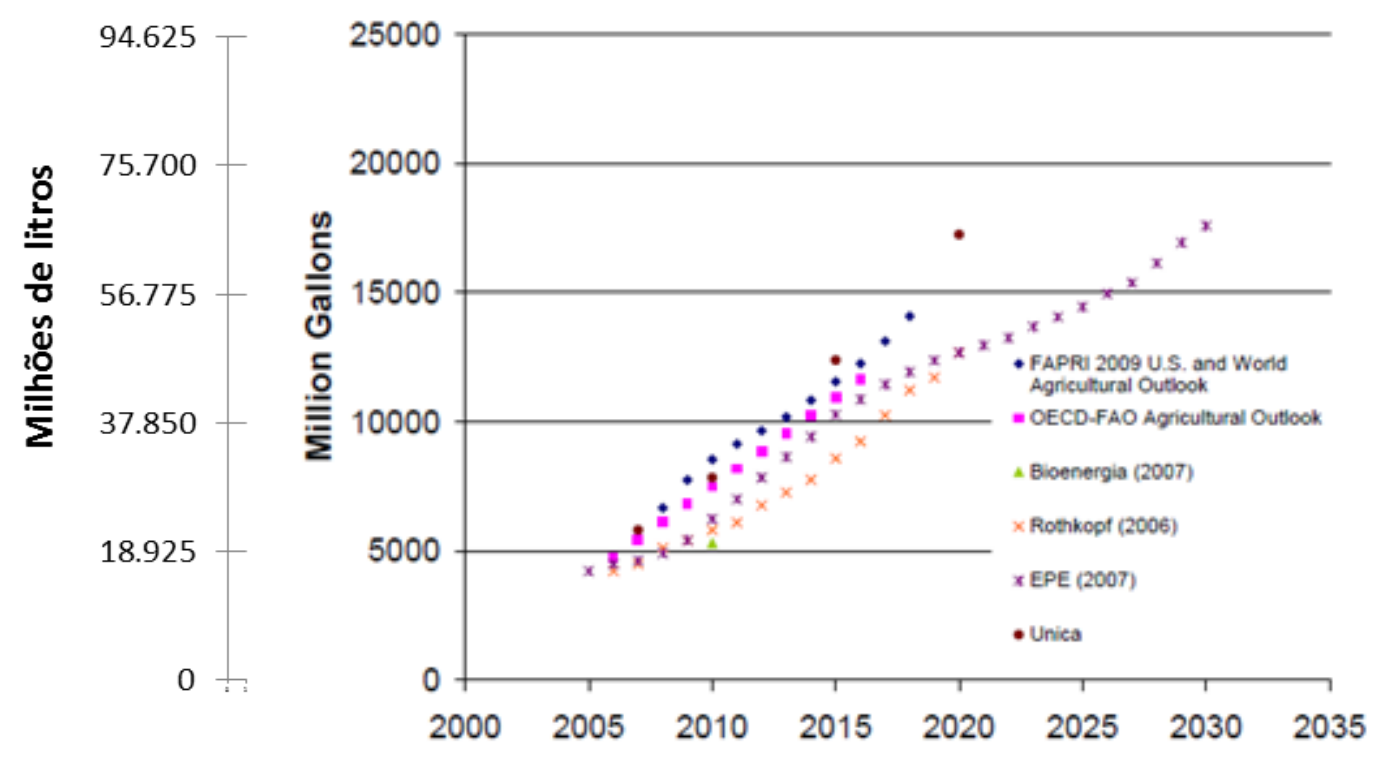

\section{Ilustração 2.4 - Projeções da capacidade de produção de etanol brasileiro.}

Fonte: Ilustração 1.5-8, p. 152, de "Renewable Fuel Standard Programs (RFS2) Regulatory Impact Analysis", publicado pela USEPA em 2010.

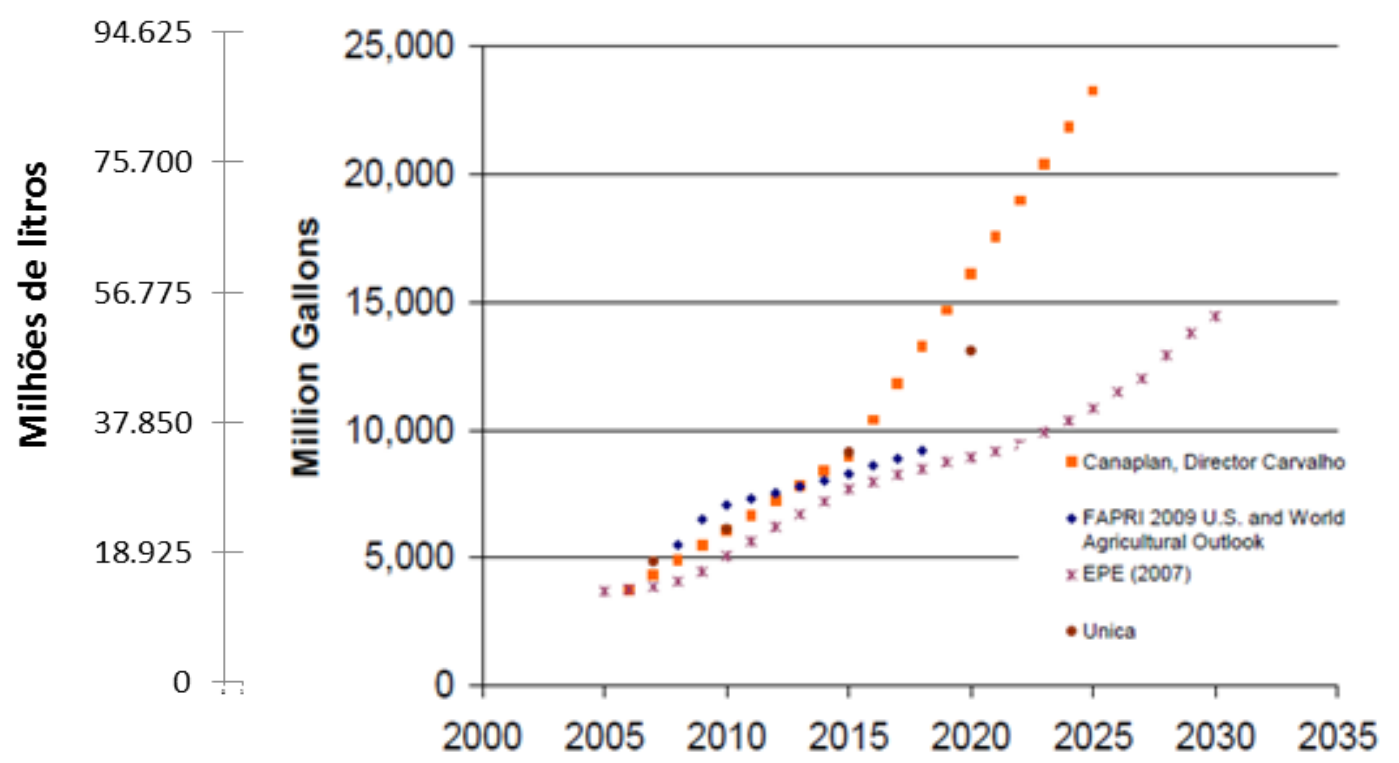

\section{Ilustração 2.5 - Projeções da capacidade de exportação de etanol brasileiro.}

Fonte: Ilustração 1.5-10, p. 155, de "Renewable Fuel Standard Programs (RFS2) Regulatory Impact Analysis", publicado pela USEPA em 2010.

Infelizmente, reforçando questionamentos dessa natureza, a partir de 2010 a produção de cana e os investimentos no setor retraíram-se no Brasil, a ponto do Brasil ter de importar etanol. Segundo a União da Indústria de Cana-de-açúcar (UNICA) (2012), isso se deveu a fatores conjunturais, como a crise financeira mundial de 2008 e a redução da produtividade agrícola e das usinas, devida a condições climáticas desfavoráveis de 2009 a 2011, mas, sobretudo, 
devido à redução da margem de lucratividade em função do aumento do custo de produção e à manutenção do preço da gasolina ${ }^{24}$, o qual, na prática, limita o preço do etanol na bomba. Ainda conforme a UNICA, isso ocasionou o agravamento da situação financeira do setor produtivo, o que provocou o fechamento de dezenas de unidade produtoras de 2008 a 2012 e, consequentemente, a perda da capacidade de processamento e do número de empregos. Outra consequência desse fato foi o deslocamento do investimento para a aquisição das empresas com dificuldades financeiras, em detrimento do investimento em novas unidades produtoras e do replantio dos canaviais. Nesse trabalho, a UNICA conclui que se não houver incentivos à produção de combustíveis, não haverá como atender o crescimento de demanda projetado para 2020.

Esse quadro tende a agravar ainda mais a preocupação dos países que consideram o Brasil como potencial fornecedor para suprir parte da demanda de etanol, quanto à sua capacidade de assegurar esse fornecimento.

Para fazer frente às atuais dificuldades, o Governo Federal vem tomando algumas medidas. Visando incentivar e disciplinar o mercado de biocombustíveis, o Governo Federal institui a Lei $\mathrm{n}^{\mathrm{o}}$ 12.490, de 16 de setembro de 2011, que busca dar maior segurança institucional aos produtores de biocombustível por meio da obrigatoriedade do estabelecimento de contratos de fornecimento com prazos dilatados. Em contrapartida, esse arcabouço legal obriga esses produtores a manterem estoques mínimos, sem, no entanto, segundo a UNICA, definir mecanismos para viabilizá-lo ${ }^{25}$. Além disso, foram anunciados o aumento dos preços dos combustíveis, apesar do impacto que causarão na inflação, e do teor de etanol a ser adicionado à gasolina C (25\% a partir de maio de 2013), a criação de crédito de PIS/COFINS para o produtor, a redução dos juros do ProRenova, linha de financiamento do BNDES para a renovação e implantação de novos canaviais, e a instituição de uma linha de financiamento a juros reduzidos para o financiamento da estocagem do etanol.

Em face desses fatos, é possível supor que o principal mercado do etanol brasileiro em curto prazo continuará sendo o mercado interno. E em função das considerações anteriores, é fácil concluir que a evolução desse mercado dependerá, primordialmente, da competitividade do etanol frente à gasolina e da evolução da frota de veículos leves.

\footnotetext{
${ }^{24}$ Ressalve-se que isso se deu em grande parte devido à redução da tributação, uma vez que o preço líquido recebido pela Petrobras cresceu em 26\% de 2006 a julho de 2012.

${ }^{25}$ Essa lei é regulamentada por meio de resoluções da ANP.
} 
Para melhor ilustrar essa questão, convém aqui antecipar o histórico de venda de veículos a álcool ou "flex", e da evolução do mercado dos combustíveis utilizados pela frota Otto, isto é, dos veículos com motores ciclo Otto.

A evolução do número de veículos leves novos vendidos por combustível no Brasil é mostrado na Ilustração 2.6. O destaque dessa ilustração é o acelerado crescimento do mercado de veículos novos. De motociclos a partir de 1993, e dos demais a partir de 2003, coincidentemente por ocasião da introdução do "flex" no mercado nacional.

Quanto ao combustível desses veículos, a evolução do mercado brasileiro fica mais evidente quando expressa em termos da participação nas vendas dos veículos leves novos por combustível, o que é mostrado na Ilustração 2.7. Nesta ilustração dois fatos chamam a atenção: a flexibilidade do mercado brasileiro à transição de combustível e o rápido avanço e o predomínio dos veículos “flex" em anos recentes.

Na Ilustração 2.8 são apresentados os gráficos da evolução do consumo anual e dos preços dos combustíveis automotivos no Brasil desde 1975. O consumo Otto é a soma dos consumos de gasolina, etanol e GNV. Esses gráficos foram construídos com dados do Balanço Energético Nacional (BEN) e da Agência Nacional de Petróleo, Gás Natural e Biocombustíveis (ANP), a partir de quando disponíveis. Ressalve-se, porém, a maior incerteza dos dados anteriores à ANP, sobretudo de preço, devido às pesquisas não utilizarem a mesma sistemática dessa agência e a grande inflação e os diversos planos econômicos ocorridos no passado. Como é possível observar nessa ilustração, apesar do preço desfavorável a partir de 1988, a existência da frota a álcool manteve o consumo do etanol relativamente estável por alguns anos enquanto a frota era progressivamente substituída por veículos a gasolina. Por outro lado, confrontando com a Ilustração 2.7, é possível observar que o preço do etanol em relação à gasolina teve um impacto direto na venda de veículos novos a álcool. No entanto, o fato do preço relativo voltar a ser favorável a partir de 1999 não foi suficiente para uma retomada mais expressiva da venda de veículos a álcool, mesmo porque a indústria automotiva praticamente os retirou do mercado. A venda do etanol hidratado só voltou a crescer significativamente após a introdução do veículo "flex", o que demonstra a importância do entendimento público sobre o combustível e a tecnologia veicular empregados. 


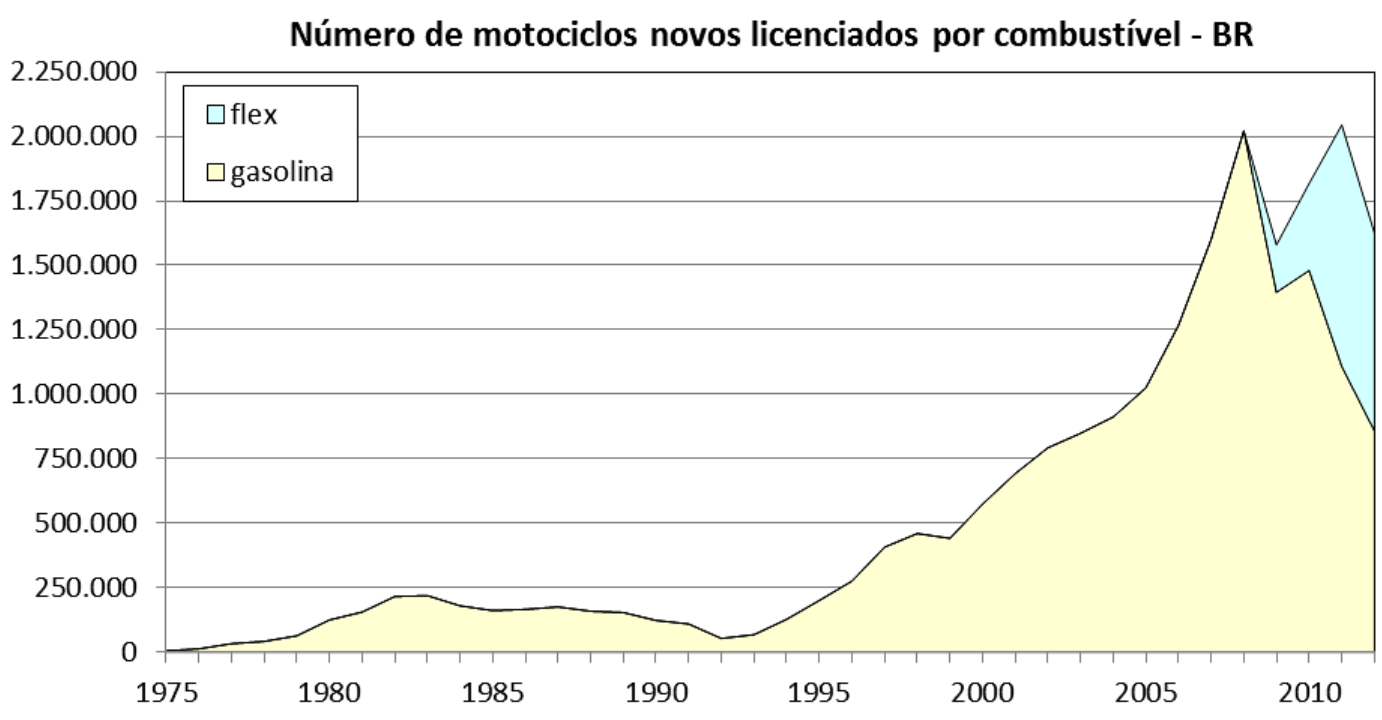

Número de automóveis novos licenciados por combustível - BR
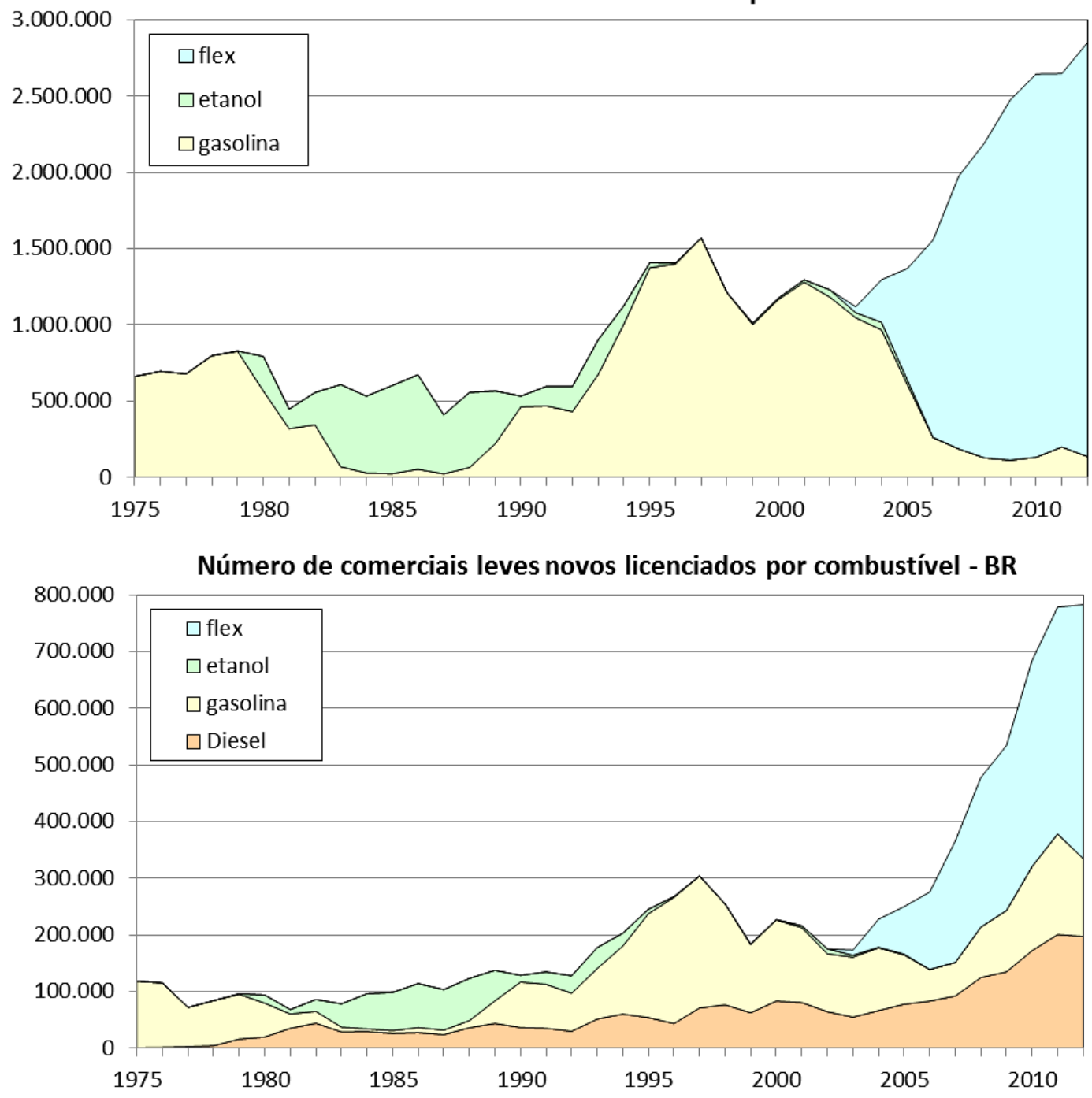

Ilustração 2.6 - Número de veículos leves novos vendidos por combustível no Brasil.

Fonte: Elaborado pelo autor com base em dados da ANFAVEA, ABEIVA e ABRACICLO, 2013. 


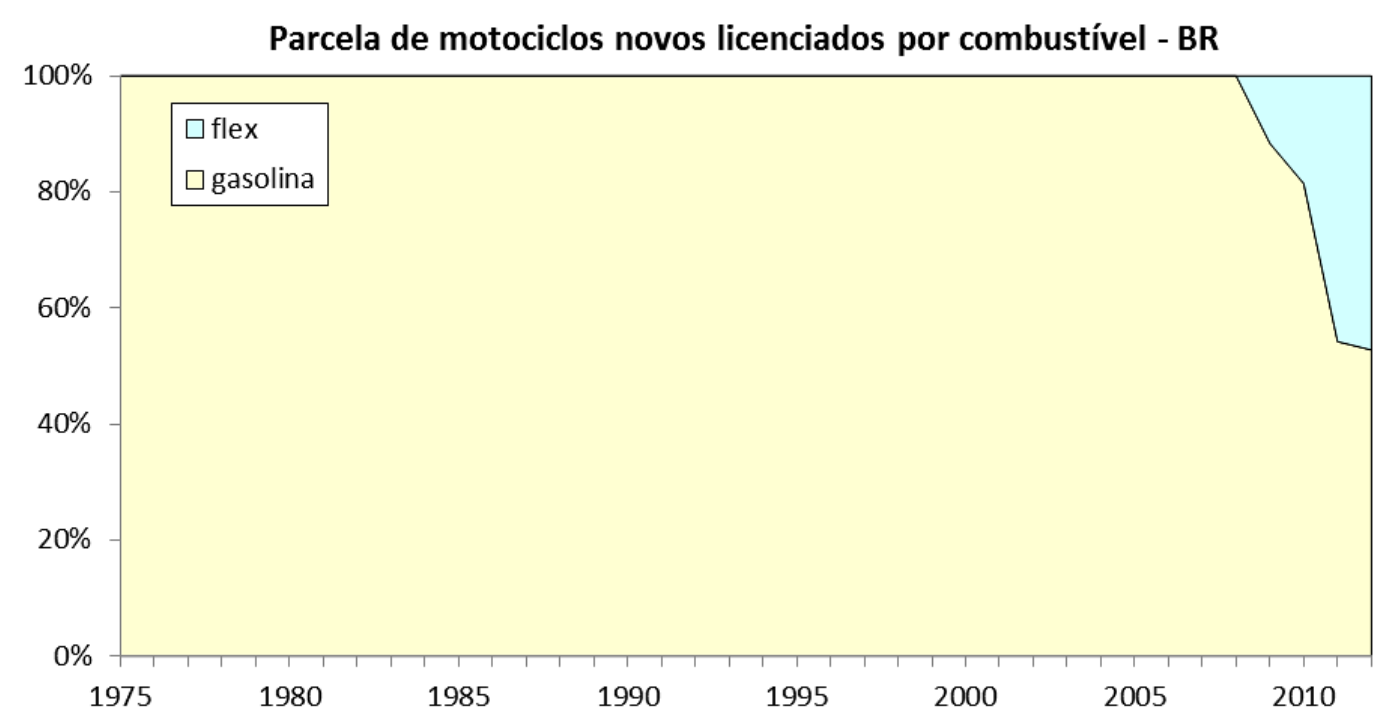

Parcela de automóveis novos licenciados por combustível - BR
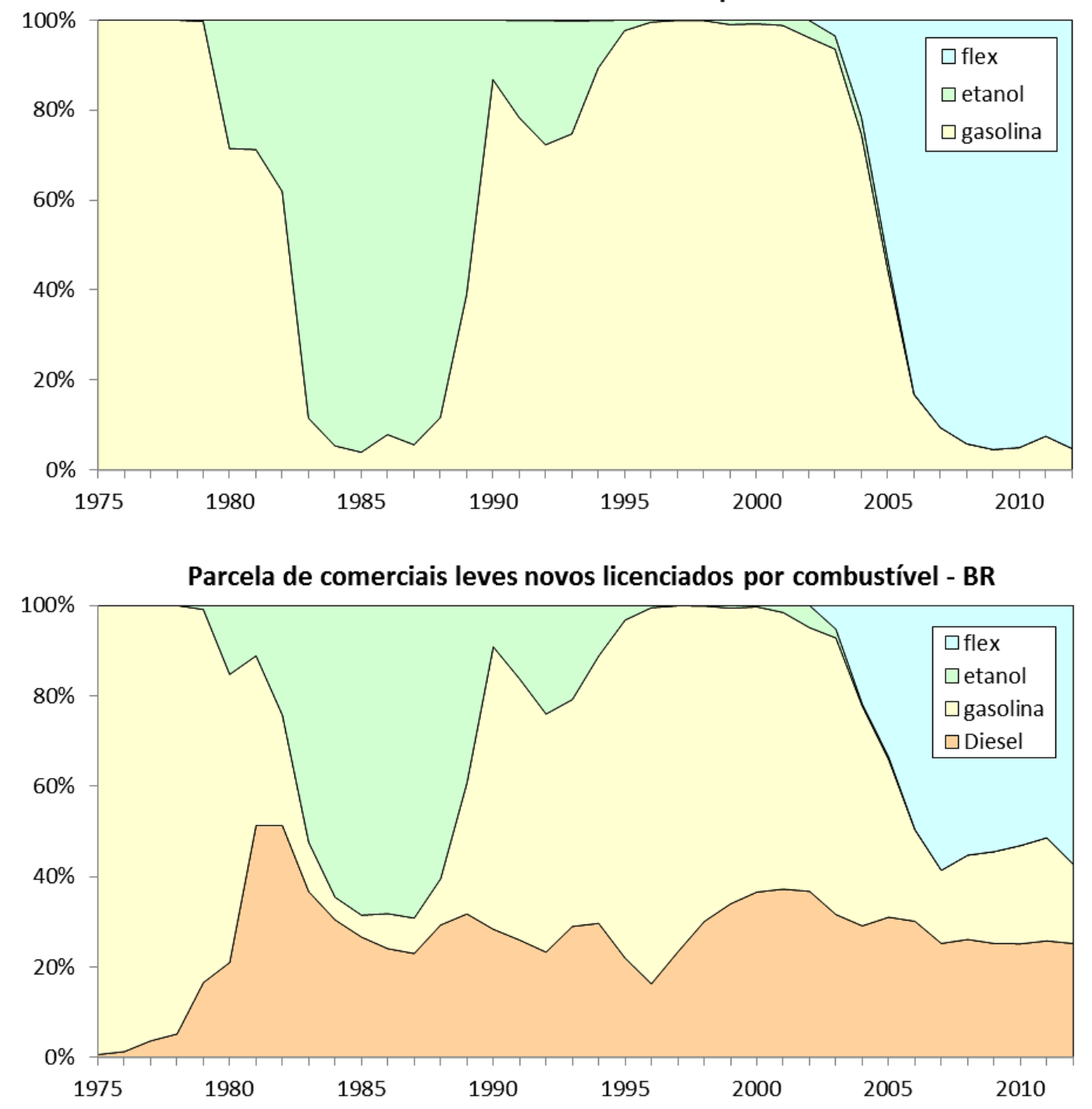

Ilustração 2.7 - Participação nas vendas de veículos leves novos por combustível.

Fonte: Elaborado pelo autor com base em dados da ANFAVEA, ABEIVA e ABRACICLO, 2013. 

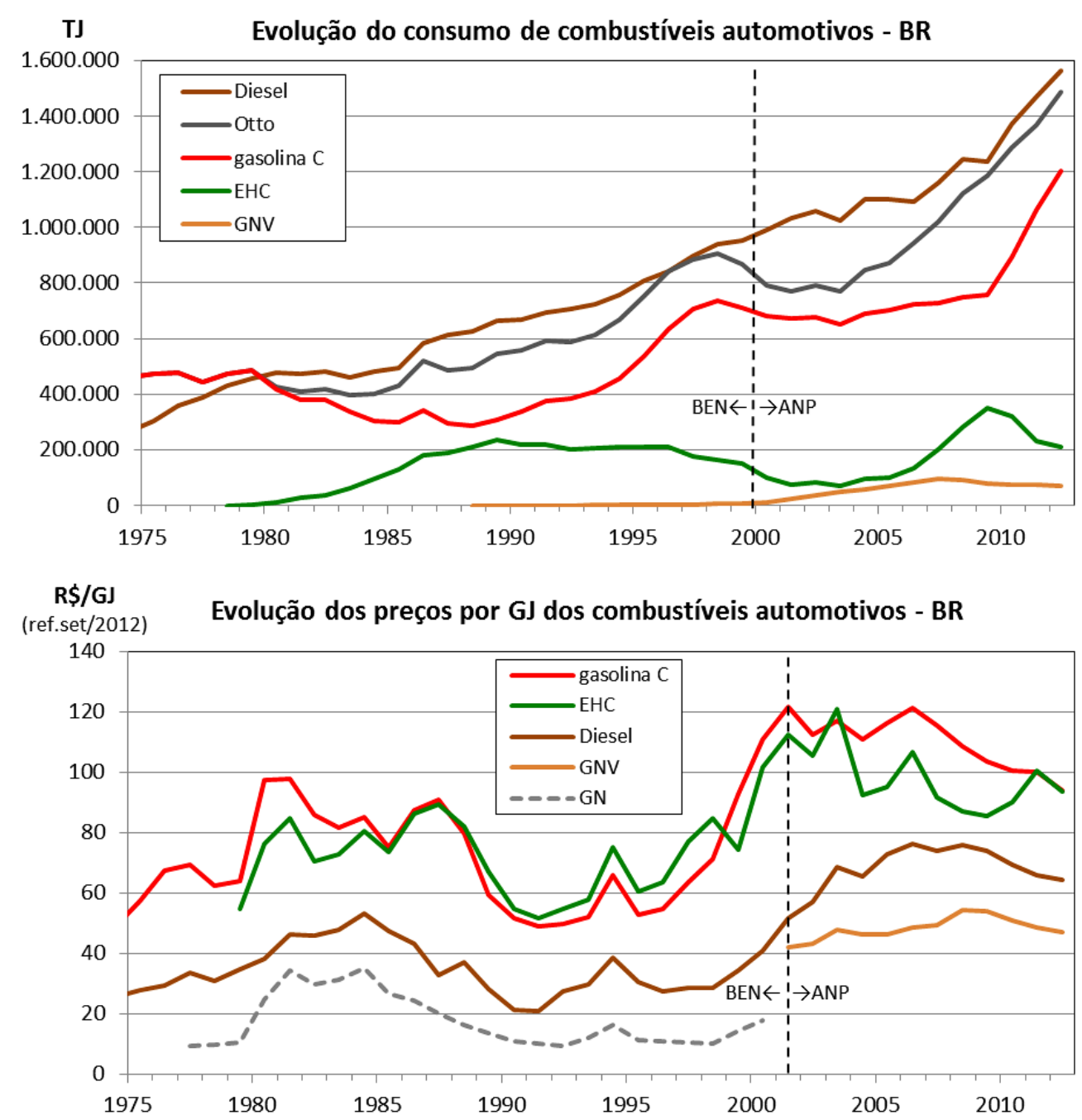

Ilustração 2.8 - Evolução do consumo e preço médio anual dos combustíveis rodoviários no Brasil. Fonte: Elaborado pelo autor com base em dados do BEN e ANP, 2013.

$\mathrm{Na}$ Ilustração 2.9 são apresentados gráficos da evolução dos preços dos combustíveis automotivos elaborados com base nos preços médios estaduais mensais do Sistema de Levantamento de Preços da ANP, corrigidos pelo INPC e, no caso do Otto, ponderado pelos correspondentes consumos. Destacam-se no primeiro gráfico da Ilustração 2.9, do preço médio por litro, além da grande variabilidade sazonal dos preços, sobretudo do etanol, a diminuição da diferença entre os preços do óleo diesel e da gasolina entre 2001 a 2003, e a progressiva redução dos preços da gasolina C e do óleo diesel que ocorreu de 2007 a 2012. No segundo gráfico, do preço por energia, nota-se adicionalmente que por diversas vezes o preço por energia do etanol se aproximou do preço do óleo diesel, mas que a partir de 2011 esse preço passou a ser semelhante ao da gasolina. Observa-se também que o preço por energia do GNV vem sendo o mais baixo entre esses combustíveis. Ressalve-se, porém que esse preço não leva em consideração, quando comparado à gasolina e o etanol, o custo adicional da conversão dos 
veículos, e quando comparado ao preço do óleo diesel, a vantagem que este último combustível tem em termos de eficiência energética devida sua queima no ciclo Diesel.
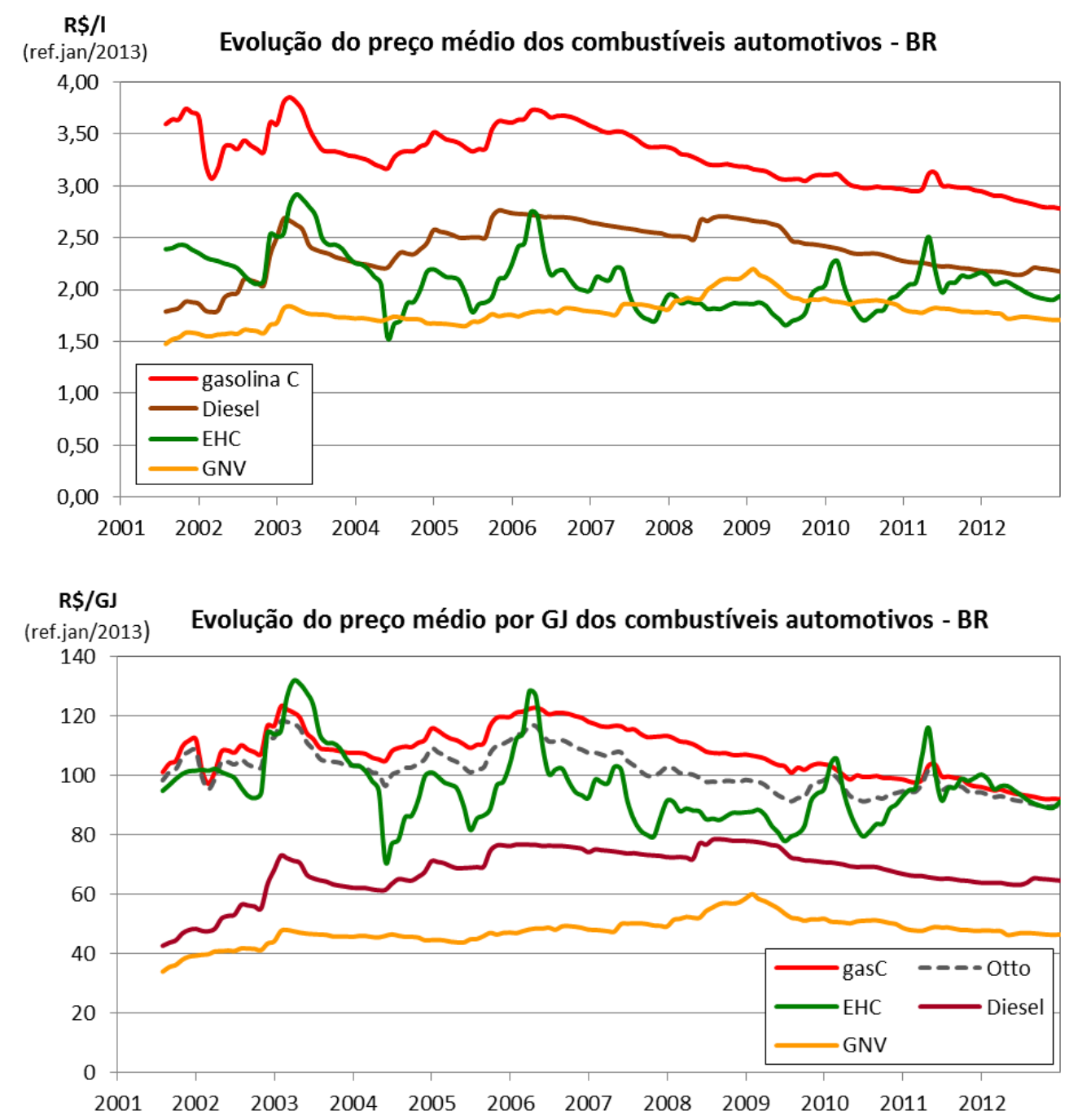

Ilustração 2.9 - Evolução do preço médio mensal dos combustíveis rodoviários no Brasil.

Fonte: Elaborado pelo autor com base em dados da ANP, 2013.

$\mathrm{Na}$ Ilustração 2.10 são apresentados gráficos da evolução dos consumos mensais de combustíveis automotivos no Brasil e no estado de São Paulo e da evolução dos preços nesse estado, corrigidos pelo INPC. Destacam-se nesses gráficos: o maior crescimento do consumo de combustíveis Otto, isto é, da soma dos consumos de gasolina C, etanol e GNV, em relação ao consumo de óleo Diesel a partir de 2004 a 2005, resultado do forte crescimento da frota de veículos leves; a expressiva maior participação relativa do etanol no estado de São Paulo, sobretudo considerando a significativa contribuição desse estado nos números do país; ao se confrontar com o gráfico correspondente da Ilustração 2.9, o menor preço do etanol em São Paulo em relação à média nacional; e principalmente que a frota "flex" torna o consumo de 
etanol bastante elástico em relação a seu preço relativo à gasolina $\mathrm{C}$, como pode ser observado nos aumentos de seus preços sazonais ocorridos em 2010 e 2011.
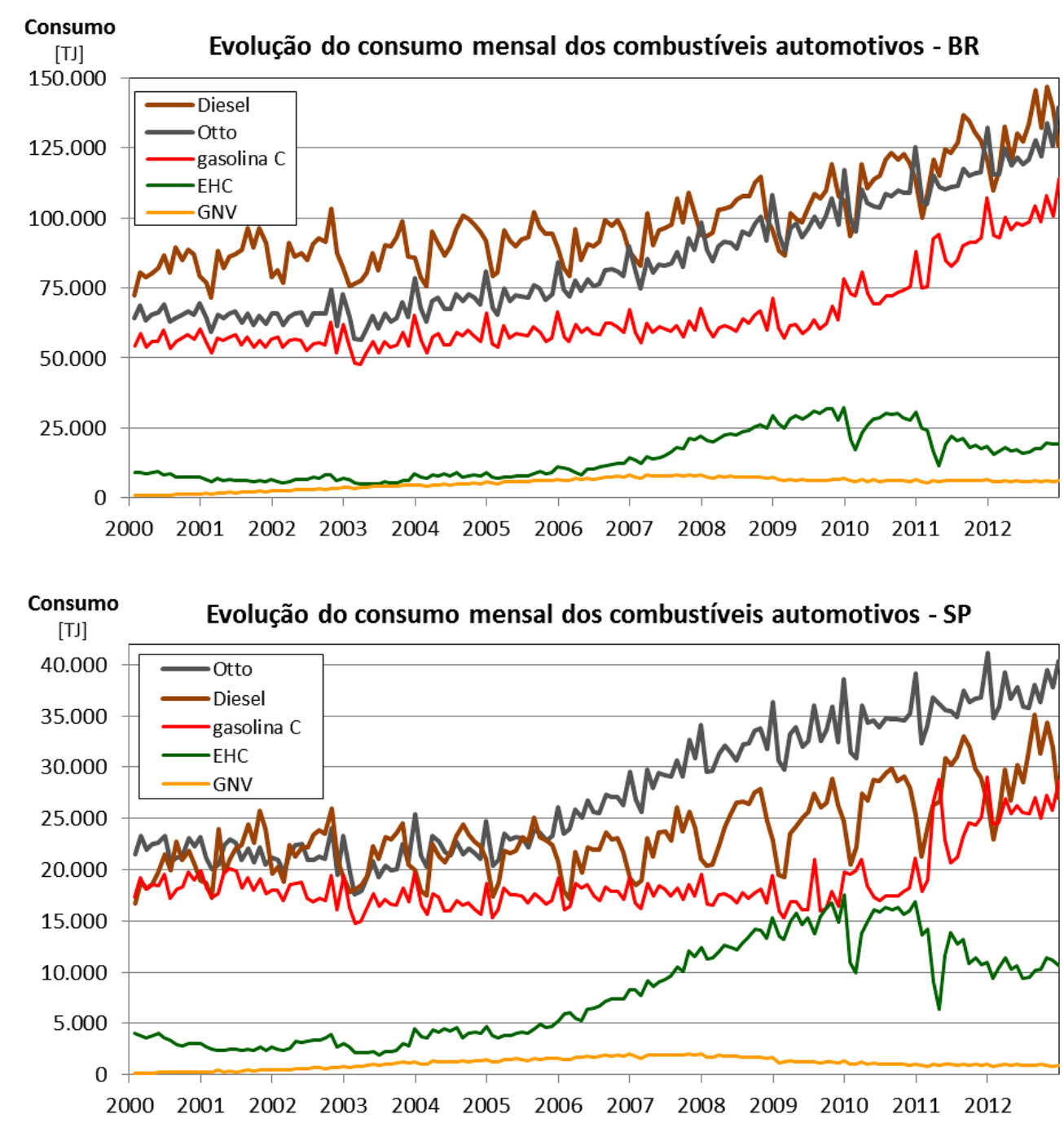

\section{$\mathbf{R} \mathbf{S} / \mathrm{GJ}$}

(ref.jan/2013) Evolução do preço por GJ dos combustíveis automotivos - SP

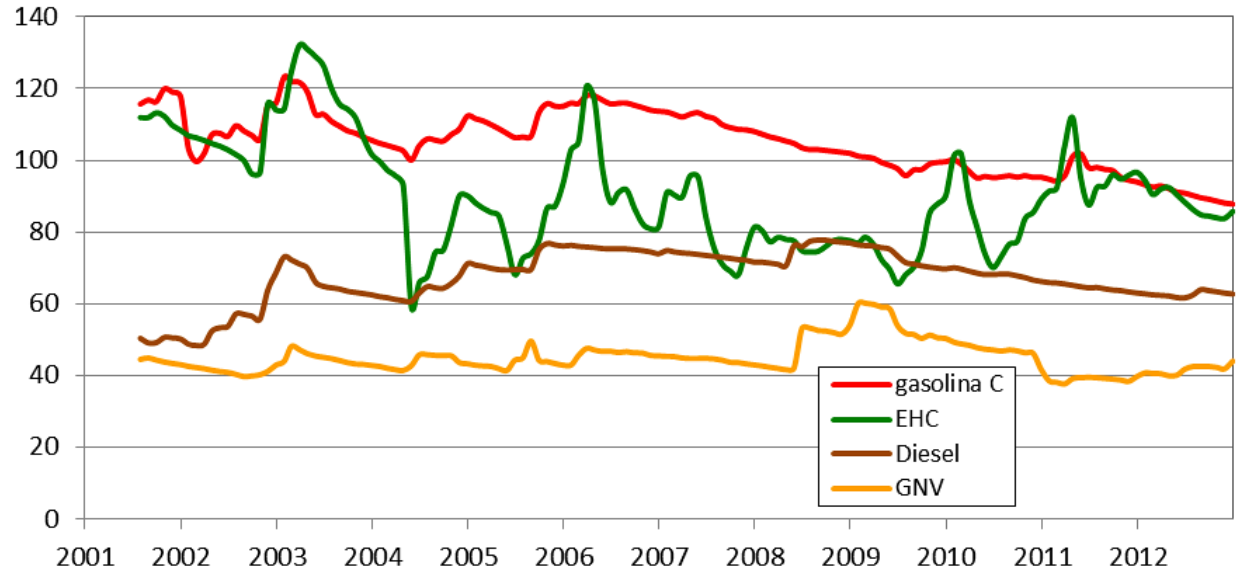

Ilustração 2.10 - Evolução dos consumos mensais e dos preços dos combustíveis Otto.

Fonte: Elaborado pelo autor com base em dados da ANP, 2013. 
Pode se inferir ainda da Ilustração 2.10, com base nos dados de 2012, a fração que caberá a cada um desses combustíveis no mercado se for mantida a atual política de manutenção do preço por energia do etanol equivalente ao da gasolina. Essa tendência será utilizada posteriormente para projetar o consumo em anos futuros.

\section{Biodiesel}

Biodiesel é combustível produzido a partir da reação de transesterificação de lipídios, tipicamente óleos vegetais e gordura animal, com monoálcoois. Usualmente é utilizado o metanol, resultando um éster metílico de ácido graxo (FAME, sigla em inglês). Alternativamente pode ser utilizado o etanol, resultando um éster etílico. Ao contrário dos óleos vegetais que apresentam cadeias carbônicas significativamente mais longas, o biodiesel é constituído por compostos orgânicos muito similares aos encontrados no óleo diesel e, consequentemente, desde que devidamente purificados dos resíduos da produção e em percentagens reduzidas, não é necessário adaptar-se os motores ciclo Diesel a este combustível, o que simplifica os aspectos tecnológicos e flexibiliza sua utilização.

Devido às diferenças na rota de produção, normalmente se distingue, inclusive sob o ponto de vista legal e fiscal, o biodiesel de outros biocombustíveis na faixa do óleo diesel, como por exemplo, o HBio e o "diesel de cana”. O HBio é a marca da Petrobras para o óleo diesel parafínico produzido por meio da hidrogenação do óleo vegetal nas unidades de hidro tratamento das refinarias. Por razões não declaradas, o HBio não vem sendo produzido ${ }^{26}$. $\mathrm{O}$ "diesel de cana" é gerado a partir da fermentação da cana, resultando, porém, em hidrocarbonetos na faixa do óleo diesel. Essa alternativa será mais bem descrita abaixo.

O estudo do uso de biodiesel no Brasil iniciou-se no final da década de 70, por ocasião da crise do petróleo, devida a premência de buscar-se uma alternativa ao óleo diesel. Visando avaliar e promover essa alternativa, o Governo Federal instituiu em 1981 o Programa de Óleos Vegetais (OVEG) (BRASIL 1983). Sem o mesmo enfoque ambiental hoje existente, a conclusão do OVEG foi que, apesar de tecnicamente viável, o biodiesel era inviável economicamente, sobretudo diante do declínio do preço do petróleo que ocorreu nessa época.

A questão do uso do biodiesel foi retomada no Brasil no início dos anos 2000. Sob as principais justificativas de ser um combustível renovável, da necessidade de reduzir-se a emissão de GEE

\footnotetext{
${ }^{26}$ Vide <http://www.biodieselbr.com/noticias/em-foco/h-bio-sumiu-30-07-09.htm>, acessado em 09/03/2012.
} 
e de poluentes tóxicos, e de gerar trabalho e renda nas regiões mais carentes do país, o Governo Federal instituiu em 2004 o Programa Nacional de Produção e Uso de Biodiesel (PNPB) ${ }^{27}$ e em 2006 o Plano Nacional de Agroenergia (PNA) (BRASIL 2006).

Para estimular a implantação dessa nova cadeia produtiva, o Governo Federal impôs, por força de lei, uma percentagem de biodiesel a ser adicionada ao óleo diesel. Para assegurar a livre concorrência e o equilíbrio entre a produção e a demanda, o volume de biodiesel necessário é adquirido por meio de leilões, ou seja, a valor de mercado. A uniformidade da produção e a qualidade do biodiesel passaram a ser reguladas pela ANP.

Atualmente se mistura ao óleo diesel 5\% de biodiesel, percentual que estava previsto para este ano, mas que foi antecipado para 2010 em função do pleito de seus produtores. Hoje, argumentando existir uma capacidade de produção instalada ociosa da ordem de $33 \%$, esses produtores estão pleiteando que o governo aumente o teor de biodiesel para $7 \%$ ou mais.

Entretanto, os resultados alcançados, os objetivos e as metas do PNPB e do PNA precisam ser reavaliados. Já em 2009, o Governo Federal identificou a necessidade de fazer ajustes. Os mecanismos de regulação adotados até então não estavam sendo capazes de assegurar o atendimento dos objetivos sócios regionais originais desses programas. E para melhor promover a agricultura familiar, a produção nas regiões Norte, Nordeste e Sul, e outras oleaginosas, em 2009 o Ministério do Desenvolvimento Agrário, por meio da Instrução Normativa $n^{\circ}$ 01/2009, criou o Selo Combustível Social ${ }^{28}$. Em linhas gerais, este Selo concede aos grandes produtores de biodiesel que prestarem assistência técnica e comprarem volumes mínimos de matérias primas de agricultores familiares ou de suas cooperativas, com anuência das correspondentes entidades de classe regionais, a redução das alíquotas de PIS/PASEP e COFINS, incentivos comerciais e crédito com taxas reduzidas. Esses incentivos dependem da matéria prima adquirida e da região onde isso ocorre.

Apesar do Selo Combustível Social, uma recente publicação do Instituto de Pesquisa Econômica Aplicada (IPEA) (BRASIL 2012) sugere que, apesar de algumas melhoras, os problemas associados aos objetivos sociais e regionais almejados pelo programa permanecem. Isso diante das seguintes constatações:

\footnotetext{
${ }^{27}$ Maiores informações sobre o PNPB pode ser obtidas em <http://www.mme.gov.br/programas/biodiesel/> .

${ }^{28}$ Para maiores informações vide <http://www.mda.gov.br/portal/saf/programas/biodiesel/2286313>, acessado em $13 / 03 / 2012$
} 
- Apesar de sua baixa produtividade de óleo (somente 19\% de sua massa), $80 \%$ do biodiesel produzido em 2011 provieram da soja. Do restante, 16\% vieram de gordura animal e somente $4 \%$ de outras fontes.

- Do biodiesel de soja produzido, 82,5\%, ou seja, cerca de dois terços do biodiesel total, provêm dos estados de RS, GO, MT e SP. Somente $15 \%$ da produção provêm das regiões Norte e Nordeste, mais carentes.

- Grande parte da produção do biodiesel de soja está concentrada nas mãos de algumas poucas empresas $(47,6 \%$ nas cinco maiores, $74,5 \%$ nas dez maiores e 96,5\% nas vinte maiores empresas) com grande participação de capital estrangeiro. Além disso, as empresas mais fortalecidas são aquelas que optaram pela produção verticalizada.

- O Selo Combustível Social tem servido muito mais aos propósitos dos grandes produtores do que aos dos agricultores familiares.

- Os mecanismos hoje existentes não são capazes de alavancar as pequenas e médias empresas, nem outras culturas.

- O alto custo não competitivo com o óleo diesel.

Em resumo, a soja tem a seu favor o porte de sua indústria e a proximidade de seus centros produtores dos centros consumidores, mas ela não favorece a distribuição regional e a inserção social, um dos principais propósitos do governo quando implantou o PNPB. A despeito da regulação hoje existente, somente as empresas com muitos recursos financeiros, competência técnica e escala de produção são competitivas.

Cerca de oito anos após sua implantação, outras de suas premissas básicas também vêm sendo questionadas. De acordo com Cavalett (2008), o balanço de energia das práticas correntes de produção de biodiesel de soja no Brasil resulta em um saldo positivo de somente cerca de $31 \%$, o que indicaria uma baixa renovabilidade. Ele afirma ainda que essas práticas estão causando um grande impacto negativo nos ecossistemas brasileiros. Ele destaca, porém, que esses resultados podem ser mais favoráveis caso sejam adotadas novas formas de produção, citando o bom exemplo de uma das empresas instaladas no Brasil.

Segundo a USEPA, a redução da emissão de GEE advinda do uso do biodiesel proveniente da soja em relação à gasolina é de somente 22\%, como mostrado na Ilustração 2.2 anterior. Ressalve-se, entretanto, que a análise do ciclo de vida de biocombustíveis é, em geral, bastante complexa, fortemente dependente de condições locais e consequentemente, controversas. Como referência, convém lembrar que a USEPA atribui ao etanol de cana nessa publicação uma redução de $56 \%$, número posteriormente revisto para $61 \%$. 
No que tange às emissões tóxicas, o biodiesel também não tem um impacto muito significativo, sobretudo nas percentagens de adição que vem sendo consideradas. Em linhas gerais, ele pode proporcionar um ligeiro decréscimo das emissões de $\mathrm{CO}, \mathrm{HC}$ e $\mathrm{MP}$, mas por outro lado ocasiona um pequeno acréscimo das emissões de $\mathrm{NO}_{\mathrm{X}}$ (NIGRO et al 2007). Outro aspecto desfavorável ao biodiesel nesse contexto é que o maior rigor que vem sendo imposto pela legislação no controle das emissões tóxicas requer cada vez mais ajustes do conjunto motorcombustível e especificações técnicas do combustível cada vez mais apertadas, fato que tende a reduzir a flexibilidade da adição do biodiesel.

\section{Biocombustíveis de segunda geração}

São classificados como biocombustíveis de segunda geração, muitas vezes também denominados biocombustíveis avançados, aqueles cuja sua extração da biomassa, vegetal ou animal, demandam o uso de novas tecnologias. Além de fontes consagradas, consideram-se também o uso de matérias-primas com maior dificuldade para a extração do combustível, como resíduos agrícolas e florestais, algas, lixo urbano e culturas não convencionais (por ex. gramíneas como a "switchgrass"). O "diesel de cana" pode ser enquadrado nessa categoria.

O etanol de cana, apesar de ter recebido do governo estadunidense, em função da redução da emissão de GEE por ele proporcionado, a classificação legal de biocombustível avançado, é considerado um biocombustível de primeira geração.

As pesquisas nesse campo vêm sendo induzidas pelas legislações dos países desenvolvidos, como o estadunidense "Energy Independence and Security Act" de 2007, que impõe, por meio do programa Padrão de Combustível Renovável (RFS, sigla em inglês), que os combustíveis veiculares sejam progressivamente substituídos por biocombustíveis, até atingir a meta de $25 \%$ do consumo total em 2022. Originalmente previa-se que volume requerido para este ano seria provido por cerca de 57 bilhões de litros de etanol de milho, 3,8 bilhões de litros de biodiesel e 76 bilhões de litros de combustíveis avançados. No entanto, em função de sua produção estar abaixo das metas anuais estabelecidas ${ }^{29}$, a parcela dos combustíveis de segunda geração vem sendo revista pela USEPA, agência responsável pela regulamentação do RFS.

\footnotetext{
29 Vide <http://www.energyboom.com/biofuels/e\%E2\%80\%A2boom-capital-gevo-and-amyris-take-similarroutes-advanced-biofuel>, acessado em 19/04/2012.
} 
Esses novos combustíveis, que visam promover à segurança energética e a redução das emissões de GEE, precisam ser custo-efetivos e não podem impactar negativamente na cadeia de produção de alimentos, em aspectos socioeconômicos, no meio ambiente, na biodiversidade e no uso da terra. Para tanto, as alternativas precisam ser cuidadosamente avaliadas por meio de pesquisas de campo e modelagem.

Naturalmente, além da tecnologia, as chances de sucesso desses novos combustíveis estão fortemente vinculadas a questões como a qualidade e disponibilidade da biomassa, assim como nos investimentos necessários para a indústria processá-la.

Grande parte dos desenvolvimentos realizados para esse propósito foca na questão da conversão da lignocelulose presente nas fontes vegetais. Muitas vezes esses processos primeiro geram produtos intermediários, os quais são posteriormente convertidos nos combustíveis. As rotas para a quebra das grandes cadeias carbônicas da lignocelulose são divididas preliminarmente em conversões termoquímicas e bioquímicas.

A conversão termoquímica ocorre por meio do aquecimento da matéria-prima a altas temperaturas, na presença controlada de oxigênio (gaseificação) ou ausência de oxigênio (pirólise ou torrefação). Esses processos resultam em um gás (ex. gás de síntese) ou um líquido (ex. bioóleo) intermediário. A conversão bioquímica é feita por meio da fermentação por microrganismos. Para acelerar esse processo, usualmente se submete a matéria-prima previamente à hidrólise química ou enzimática, para a separação dos componentes da lignocelulose: lignina, hemicelulose e celulose.

Dependendo dos produtos intermediários, tipicamente se classificam os processos em gás-paralíquido (GTL, sigla em inglês) e biomassa-para-líquido (BTL, sigla em inglês).

Os combustíveis passíveis de serem gerados por esses processos são, em geral: hidrogênio; metano, também denominado gás natural sintético (SNG, sigla em inglês); DME; álcoois e suas misturas $^{30}$. A vantagem de produzir-se álcoois superiores ao etanol é que estes têm maior densidade energética. Conforme anunciado pela Amyris, por meio da conversão bioquímica, é também possível produzir-se hidrocarbonetos superiores. Para identificar sua origem, muitas vezes esses combustíveis são precedidos do prefixo "bio". Além disso, por meio de processos de síntese, como o Fischer-Tropsch ${ }^{31}$, é também possível se obter hidrocarbonetos superiores.

\footnotetext{
${ }^{30}$ São exemplos dessas misturas os produtos Ecalene® (de C1 a C6) e o Envirolene ${ }^{\circledR}$ (de C1 a C10).

${ }^{31}$ Síntese de monóxido de carbono e hidrogênio.
} 
Entre os biocombustíveis avançados, possivelmente o que vem recebendo maior impulso é o etanol celulósico.

\section{Diesel de cana}

O que diferencia o processo de produção do "diesel de cana" do etanol é a etapa de fermentação. O tipo de levedura aplicado ao caldo da cana e o controle do processamento, ao invés de resultar no etanol, produz hidrocarbonetos superiores, alguns na faixa de peso molecular do óleo diesel. Em relação ao etanol, ele tem a seu favor sua maior densidade energética e o fato dele poder ser utilizado em motores ciclo Diesel, de maior rendimento energético. Além disso, ao contrário do óleo diesel, ele tem a vantagem de ser isento de enxofre.

$\mathrm{Na}$ verdade, o "diesel de cana" comercializado atualmente no Brasil é um farnesano $\left(\mathrm{C}_{15} \mathrm{H}_{32}\right)$, internacionalmente registrado sob a marca Biofene ${ }^{\circledR}$ pela empresa Amyris. Sua produção em escala industrial no Brasil está sendo feita exclusivamente por parceiros comerciais dessa empresa. Este produto não é o único produto dessa natureza disponível no mercado. Outras empresas que estão desenvolvendo produtos similares são, por exemplo, a Solazyme em parceria com a Bunge, a Royal DSM em parceria com a BP, e a LS9. Possivelmente o maior motivador para o desenvolvimento desses produtos seja sua aplicação como alternativa ao querosene de aviação. O Biofene® vem sendo utilizado em diversos testes pilotos em parceria com empresas do setor aéreo como General Electric, Boeing, Airbus e Embraer.

Ainda não é possível afirmar que esse combustível tenha atingido sua maturidade comercial. Divulga-se que o preço do "diesel de cana" praticado atualmente é similar ao do biodiesel. Entretanto, para que o "diesel de cana" se consolide no mercado é necessário que ele confirme a expectativa de seus produtores quanto a sua competitividade em relação ao óleo diesel, ou no mínimo ao biodiesel, caso a legislação de incentivo a este combustível prossiga. Se isso ocorrer e forem confirmadas as expectativas positivas quanto ao ciclo de vida desse combustível, o "diesel de cana" poderá se constituir em uma importante alternativa para mitigar a emissão de GEE de transportes nacionais, dado que, como veremos adiante, crescerá significativamente a contribuição do óleo diesel para esta emissão. 


\subsubsection{Desenvolvimento da tecnologia veicular}

Além do acirramento da concorrência entre fabricantes e entre países produtores, o principal motivador do desenvolvimento da tecnologia veicular vem sendo a legislação ambiental. Atualmente não se prevê a adoção de limites de emissões tóxicas mais rigorosos do que aqueles prescritos pelas legislações ora em implantação nos países desenvolvidos (US 2010 nos Estados Unidos e EURO 6 na Comunidade Europeia). Por outro lado, a mudança do clima tem levado os governos de muitos países a estabelecerem regulamentos, sobretudo para automóveis, limitando ou o consumo de combustível ou a emissão de GEE, ou ainda obrigando o uso de uma parcela de combustíveis renováveis. Na prática, o foco do desenvolvimento veicular está migrando do controle de emissões tóxicas para o aumento da eficiência energética e o uso de combustíveis alternativos.

São diversas as fontes de ineficiência dos veículos convencionais: os atritos e perdas térmicas de motores de combustão, periféricos e sistema de transmissão (câmbio e diferencial), a resistência ao rolamento e o arrasto aerodinâmico. Consequentemente, há uma vasta gama de alternativas para aprimorar sua eficiência. Em linhas gerais, no tráfego urbano o maior dispêndio de energia está relacionado à variação de energia cinética e, consequentemente, nessa condição as medidas mais efetivas possivelmente são a redução do peso e o freio regenerativo (híbridos). Na estrada, o consumo energético é dominado pelo arrasto aerodinâmico e o foco, em princípio, deve ser a redução do coeficiente de arrasto aerodinâmico e, quando possível, da área frontal do veículo. A redução da velocidade seria favorável em ambas às situações, mas essa opção penaliza o tempo de viagem.

$\mathrm{Na}$ realidade, existem diversas tecnologias competindo na busca de veículos mais eficientes e menos poluidores. Atualmente, não existe consenso, mesmo internamente nos setores indústria automobilística, institutos de pesquisas e entidades de governo, sobre qual tecnologia prevalecerá (SCHULTZE, 2009). O que se considera é que algumas dessas tecnologias possivelmente atingirão sua maturidade em curto prazo, enquanto outras demandarão mais tempo para atingi-la.

A seguir vamos rever as principais frentes do desenvolvimento veicular segregadas em dois grupos: tecnologias convencionais e novas tecnologias. 


\subsubsection{Aprimoramento de tecnologias convencionais}

Apesar das novas tecnologias que estão surgindo, os fabricantes continuam investindo intensamente no desenvolvimento das tecnologias convencionais. É apresentado a seguir um breve relato do que vem ocorrendo.

\section{Motores e Periféricos}

As fontes de ineficiência dos motores de combustão são, em linhas gerais, os atritos internos e as energias térmica e cinética transferidas para o gás de escapamento, fluído de arrefecimento, óleo lubrificante e sistemas periféricos, tais como bomba de água de arrefecimento, bomba de óleo, alternador, etc.

A máxima eficiência energética dos motores de combustão ciclo Otto é da ordem de $30 \%$ a $35 \%$ e dos motores ciclo Diesel de $40 \%$ a $45 \%$ (RAJAGOPALAN, 2003). No entanto, a eficiência dos motores varia significativamente em função da condição de carga e rotação. Em marcha lenta sem carga, o combustível queimado não gera qualquer trabalho útil e a eficiência energética é nula. Exemplos dos mapas de eficiência de motores ciclo Otto e Diesel são apresentados na Ilustração 2.11. Fatores como o tipo e porte do veículo e transmissão definirão em que região do mapa do motor o veículo usualmente operará. Isso explica porque a adequada seleção do veículo, como tipicamente ocorre com caminhões, pode assegurar uma operação mais eficiente. De qualquer forma, é possível concluir que somente uma pequena parcela da energia química do combustível é convertida em energia mecânica para movimentar o veículo.

Por outro lado, como indicado na Ilustração 2.11, veículos leves operam tipicamente no quarto inferior direito desses mapas. Confrontando os gráficos dessa ilustração é possível verificar que a vantagem do ciclo Diesel se mantém nessa região. Essa é principal razão da maior economia dos automóveis a diesel.

Por causa disso, já há algum tempo alguns países, sobretudo na Comunidade Europeia, visando à redução da emissão de GEE, vêm incentivando a "dieselização" de sua frota de veículos leves. Porém essa estratégia tem suas limitações. Por exemplo, caso esse processo de "dieselização" venha a ocorrer também nos Estados Unidos, isso alteraria o atual balanço de demanda de gasolina e óleo diesel e, consequentemente, o equilíbrio de preços relativos desses combustíveis. No passado, como as agências ambientais norte-americanas não privilegiavam tecnologias, a legislação ambiental restringia a penetração de veículos leves diesel nesse 
mercado. Entretanto, hoje esses veículos já são capazes de atender aos limites de emissões tóxicas mais rigorosos.

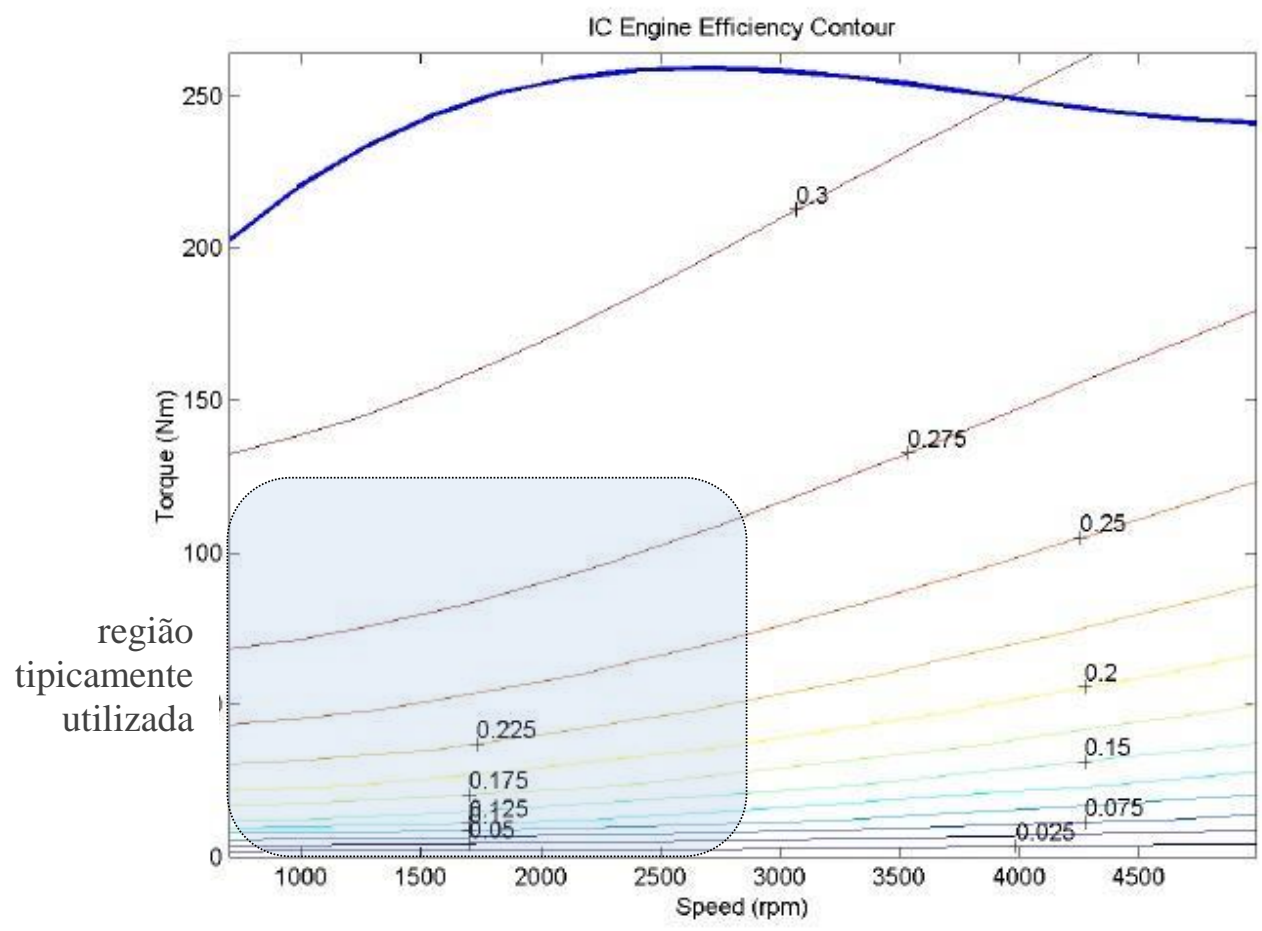

Mapa de eficiência de um motor ciclo OTTO de 3.0 L

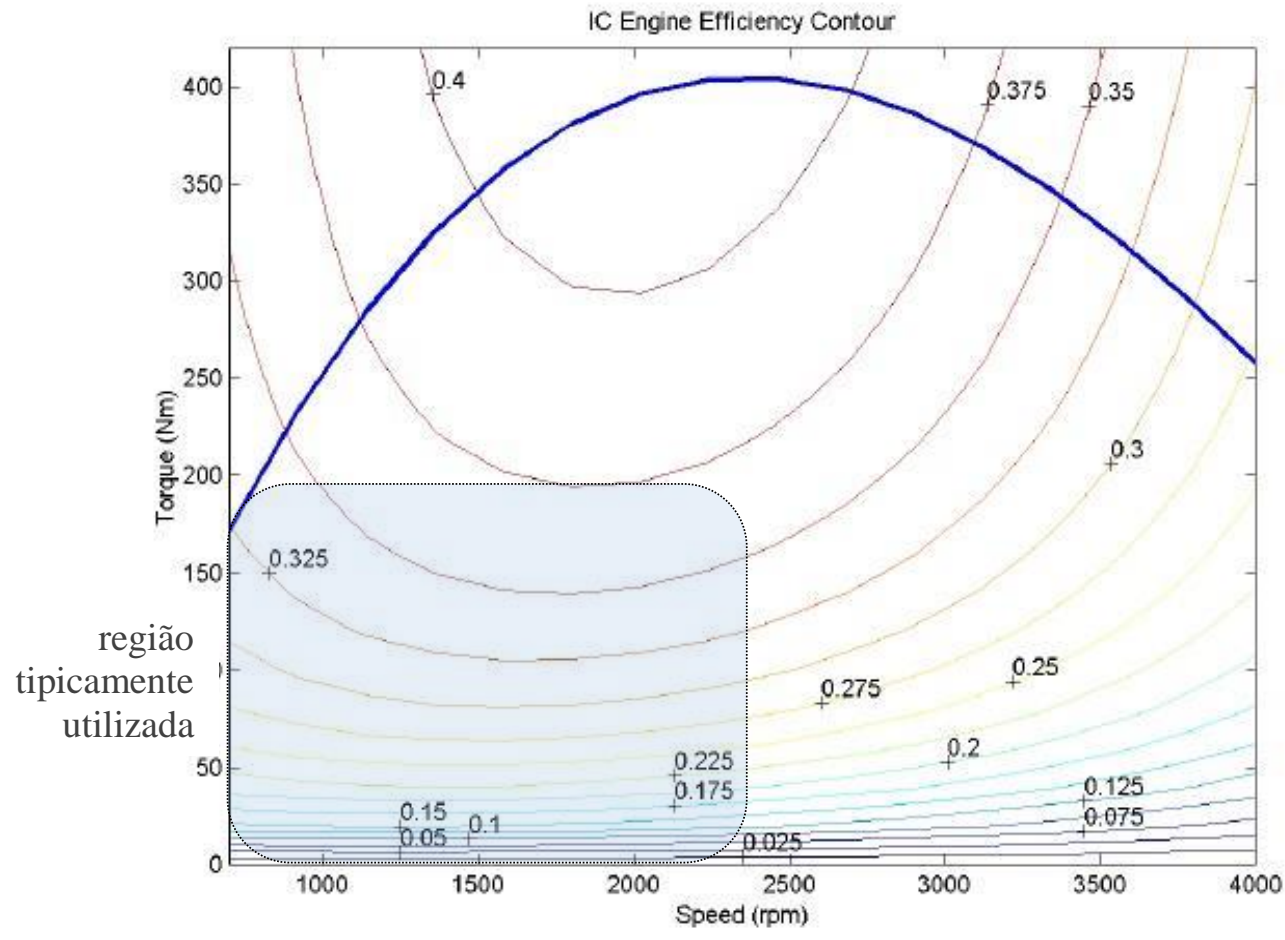

Mapa de eficiência de um motor ciclo DIESEL de 4.0 L

Ilustração 2.11 - Exemplos de mapas de eficiência de motores ciclo Otto e ciclo Diesel.

Fonte: Ilustrações 23 e 25 do artigo de Rajagopalan, A. et al. "Development of Fuzzy Logic and Neural Network Control and Advanced Emissions Modeling for Parallel Hybrid Vehicles", NREL, 2003. 
A liberação do uso de óleo diesel em automóveis vem sendo solicitada e estava inicialmente prevista para ser implantada no Brasil a partir de 2014 ${ }^{32}$. Destaque-se, entretanto, como já anteriormente avaliado, que não necessariamente essa alternativa reduzirá a emissão de $\mathrm{CO}_{2}$ quando comparada com a gasolina $\mathrm{C}$ nacional, em função de seu conteúdo de etanol.

Além da "dieselização" dos veículos leves, existem diversas outras frentes para aumentar-se a eficiência dos motores e de sua aplicação. Abaixo são listadas as principais estratégias que vêm sendo utilizadas, algumas de aplicação geral, algumas exclusivas de alguns segmentos.

- Redução da massa e da inércia rotativa, por meio do uso de materiais mais leves e o aperfeiçoamento do desenho das peças girantes dos motores.

- Visando à redução do atrito interno, aperfeiçoamento de anéis e mancais e o uso de óleos lubrificantes de menor viscosidade ${ }^{33}$. Ainda com esse mesmo propósito, alguns fabricantes estão reduzindo o porte dos motores ciclo Otto ("downsizing") ou sua rotação de trabalho ("downspeeding"), associado ao uso de turbo compressores ("turbocharging") ou de compressores mecânicos ("supercharger"), para a manutenção da potência.

- Para aumentar a eficiência do motor nas condições mais desfavoráveis de operação, estão sendo aplicados comandos de válvulas variáveis com diferentes graus de sofisticação, e esquemas de desativação de parte dos cilindros.

- Para reduzir o tempo de operação dos motores em marcha-lenta, utilização de sistemas de partida-parada automáticos ("start-stop").

- Visando à redução de perdas térmicas, aperfeiçoamento do sistema de arrefecimento.

- Objetivando aumentar a eficiência térmica, estão sendo empregados motores ciclo Otto com injeção direta de gasolina (GDI, sigla em inglês), tecnologia que pode ser ainda mais vantajosa se aplicada para combustíveis de composição mais uniforme, como o etanol.

- Visando reduzir seus consumos de energia de periféricos e acessórios, tais como ventiladores, compressores, direção assistida e ar condicionado, estes vem sendo aperfeiçoados, muitas vezes por meio de sua eletrificação.

Convém aqui fazer uma ressalva em relação aos veículos a combustível flexível (FFV, sigla em inglês) ou, popularmente, "flex". Eles foram introduzidos no mercado estadunidense na década de 90 em função de um quesito da "Energy Policy Act" de 1992 que obrigava os frotistas a

\footnotetext{
${ }^{32}$ Vide artigo em < http://jornale.com.br/mirian/?p=15746 >, acessado em 19/01/2012.

33 A Toyota estima que óleos lubrificantes de menor viscosidade possam proporcionar ganhos de consumo da ordem de 0,7\% em automóveis (SWEDBERG 2011).
} 
terem uma parcela de veículos a combustível alternativo em suas frotas. Os "flex" atendiam a esse quesito mesmo rodando com gasolina. Mas foi em nosso contexto favorável, apesar de alguma resistência inicial das montadoras e dos próprios produtores de etanol, que essa tecnologia se difundiu.

A contribuição nacional para a tecnologia "flex" foi utilizar o sinal do sensor de oxigênio já existente para detectar o teor de etanol no combustível. Esse sinal, associado a um mapa digital do motor ampliado ${ }^{34}$ adequado, é suficiente para ajustar os sistemas de injeção e de ignição ao combustível utilizado, dispensando o uso de um sensor específico para esse fim.

Para obter-se o melhor aproveitamento energético dos combustíveis, idealmente, conviria também ajustar-se a taxa de compressão, mas com a tecnologia atualmente aqui empregada isso não é possível e, consequentemente, se utiliza uma solução de compromisso. A taxa mais adequada ao etanol é superior a da gasolina. Com essa taxa, para não ocorrer detonação quando operando com gasolina em cargas altas, é necessário reduzir o avanço de ignição. Isso resulta em perda de rendimento térmico em relação ao motor equivalente exclusivamente à gasolina nas mesmas condições de operação, e em um acréscimo da temperatura no escape.

Como alta carga é uma condição incomum em veículos leves, em princípio, o uso de uma taxa de compressão mais adequada ao etanol parece ser a mais indicada. Porém muitas vezes não é isso que ocorre na prática. Muitos fabricantes preferem utilizar taxas mais conservadoras e próximas àquelas dos motores a gasolina, o que resulta em uma dirigibilidade com gasolina ou etanol similar e um menor estrese do motor, mas em um pior aproveitamento do potencial do etanol. O uso de comandos de válvulas variáveis e compressores irão contribuir para a mitigação ou solução dessa questão.

\section{Sistemas de pós-tratamento}

Denominam-se sistemas de pós-tratamento aqueles que são introduzidos nos veículos ou motores normalmente depois de esgotados os recursos para o controle das emissões poluentes tóxicas via o aperfeiçoamento do próprio motor de combustão. Isto é, quando o aprimoramento dos sistemas de controle e do processo de combustão do motor não for mais suficiente para atender a limites de emissões mais rigorosos, torna-se necessário introduzir um dispositivo

\footnotetext{
${ }^{34}$ Dados contidos no módulo eletrônico central (ECU, sigla em inglês) do motor que, em função dos sinais dos sensores existentes (rotação, sonda lambda, etc.) permitem o ajuste de injetores, avanço de ignição, etc.
} 
externo ao motor, usualmente um conversor catalítico, ou simplesmente, como é comumente denominado, um catalisador. Como será mostrado, há um forte vínculo entre a tecnologia dos motores, dos sistemas de pós-tratamento e combustíveis que, por força da legislação de restrição às emissões tóxicas, precisam evoluir concomitantemente.

Tipicamente, os conversores catalíticos automotivos são constituídos por núcleo cerâmico ou metálico, repleto de passagens muito finas que visam aumentar a superfície de contato, e que serve de base, ou substrato, para a deposição de uma solução ("wash coating") contendo metais nobres, como platina, paládio e ródio. Esses metais catalisam, isto é, aceleram as reações químicas de oxidação ou redução dos gases de escapamento. Para ser aplicado nos veículos, esse núcleo é encapsulado por uma carcaça metálica configurada para ser montada no duto de escapamento $^{35}$. Seu posicionamento ao longo do duto de escapamento é feito em função do compromisso entre um rápido aquecimento mínimo necessário para disparar a ação do catalisador (“light-off”) e a temperatura máxima de operação, acima da qual o substrato pode colapsar ("melt down").

Os primeiros veículos que utilizaram catalisadores foram os automóveis com motores ciclo Otto. As emissões mais críticas desses motores são o $\mathrm{CO}$, hidrocarbonetos (HC) e aldeídos (RCHO), resultantes da combustão incompleta do combustível. Para diminuir a emissão desses compostos, inicialmente foi utilizado o catalisador de oxidação. No entanto, esses motores também emitem $\mathrm{NO}_{\mathrm{X}}$ e uma pequena parcela de MP. Como os motores ciclo Otto convencionais operam com misturas ar-combustível em torno da mistura estequiométrica ou ligeiramente enriquecidas, ou seja, sem excesso de oxigênio, o catalisador veicular logo evoluiu para catalisador de três vias (TWC, sigla em inglês)) capaz de oxidar o $\mathrm{CO}$, o $\mathrm{HC}$ e a fração orgânica do material particulado, e, simultaneamente, reduzir quimicamente os $\mathrm{NO}_{\mathrm{X}}$. Essa tecnologia, que vem sendo utilizada desde a década de 80, apesar de continuar evoluindo, já está consolidada.

Já para os veículos com motores ciclo Diesel, cujas emissões mais críticas são $\mathrm{NO}_{\mathrm{X}} \mathrm{e} \mathrm{MP}$, existe uma gama maior de alternativas que podem ser utilizadas. $O$ desenvolvimento de sistemas de pós-tratamento para esses motores é uma realidade relativamente recente. Já existem algumas classes de equipamentos definidas e algumas soluções razoavelmente

\footnotetext{
${ }^{35}$ Uma boa animação sobre o aspecto físico e a operação de um catalisador pode ser visto em <http://www. umicore.com.br/nossosNegocios/produtosMetaisPreciososCatalisadores/Catalisadores/catalisador.htm>, acessado em 24/7/2013.
} 
consolidadas, mas ao contrário do que ocorre para veículos com motores ciclo Otto, ainda não há o predomínio de uma tecnologia específica. A avaliação da conveniência da aplicação de cada alternativa depende de um conjunto mais complexo de considerações. Na verdade, de uma forma mais contundente do que acontece com os motores ciclo Otto, as soluções em discussão envolvem não somente o sistema de pós-tratamento propriamente dito, mas a otimização do conjunto motor de combustão-sistema de pós-tratamento, de forma a obter-se a melhor solução entre os diversos compromissos existentes. Isso ficará mais claro adiante à medida que forem descritas as alternativas existentes.

Um agravante para a aplicação de sistemas de pós-tratamento em motores diesel é o volume de MP emitido. Ao contrário dos demais poluentes que são gases, o material particulado, ou aerossol, é composto por partículas finas, sólidas ou líquidas, de $10 \mathrm{~nm}$ a $100 \mu \mathrm{m}$, suspensas no gás. Em particular, o MP presente nos gases de escapamento dos motores é composto por metais, HC, inclusive policíclicos aromáticos (HPA), e sulfetos adsorvidos em carbono negro (BC, sigla em inglês), que, dependendo de suas características, podem rapidamente bloquear ou deteriorar os conversores catalíticos convencionais. Além de sua composição, o desenvolvimento dos sistemas de pós-tratamento de motores diesel deve também levar em consideração a distribuição do tamanho de partículas. Para diferenciar o tamanho do material particulado é comum utilizar-se a nomenclatura $\mathrm{MP}_{n}$, que denota o material particulado de tamanho inferior a $\boldsymbol{n} \mu \mathrm{m}$. Por exemplo, $\mathrm{MP}_{10}$ é o material particulado inferior a $10 \mu \mathrm{m}$. As emissões de MP dos motores estão cada vez menores, mas são tipicamente inferiores a $\mathrm{MP}_{2,5}$. São apresentadas, a seguir, as principais tecnologias de sistemas de pós-tratamento aplicáveis a motores ciclo Diesel.

O catalisador de oxidação diesel (DOC, sigla em inglês) é semelhante ao catalisador de oxidação dos motores ciclo Otto e, como ele, tem por objetivo a oxidação do CO, HC e das frações orgânicas do MP, reduzindo-lhe sua massa. No entanto, sua aplicação requer alguns cuidados. Os metais preciosos dos catalisadores podem converter o $\mathrm{SO}_{2} \mathrm{em} \mathrm{SO}_{3}$, o qual reage com a umidade contida no gás de escape, gerando ácido sulfúrico $\left(\mathrm{H}_{2} \mathrm{SO}_{4}\right)$ fumegante, que, por sua vez, além de corroer o sistema de escape e contribuir para a chuva ácida, aglomera-se ao material particulado, aumentado sua massa. Portanto, a formulação do DOC deve levar em consideração o teor de enxofre contido no óleo diesel. Caso o teor de enxofre seja alto, é necessário diminuir a concentração de metais nobres.

Os principais ganhos obtidos com o DOC são, conforme literatura, as reduções de $30 \%$ a $95 \%$ de $\mathrm{CO}$ e $\mathrm{HC}$ e de, tipicamente, menos de $30 \%$ do material particulado. Entretanto, sua eficácia 
tende a reduzir-se com o uso, em função do depósito de material particulado em seus poros e do envenenamento do metal precioso, problemas esses que podem ser minimizados com o uso de um óleo diesel de mais baixo teor de enxofre. Por suas características, possivelmente o DOC é a alternativa de pós-tratamento de menor custo.

Como será visto adiante, o DOC pode operar em conjunto com os demais catalisadores descritos a seguir.

O filtro de particulados diesel (DPF, sigla em inglês) se assemelha ao catalisador convencional, mas com sua configuração física otimizada para filtrar o material particulado contido nos gases de escapamento. O DPF tende a se saturar com o uso, o que compromete o desempenho do motor. Para que isso não aconteça, é necessário limpá-lo continuamente. Essa limpeza pode ser feita externamente, o que exige sua desmontagem, ou é necessário dispor de um mecanismo que o aqueça acima de $500^{\circ} \mathrm{C}$, o que ocasiona a queima de grande parte do material sobre ele depositado. Esse aquecimento pode ser feito por meio do uso ou de dispositivos externos ao motor, como uma resistência elétrica ou um queimador de combustível, ou durante a própria operação do veículo por meio de medidas que assegurem, sempre que necessário, a elevação da temperatura dos gases de escapamento ao nível requerido. DPFs nessa categoria são denominados filtro de particulados diesel continuamente regenerável (CRDPF, sigla em inglês).

Outra medida utilizada para promover esse aquecimento envolve o uso de um DOC a montante do DPF. Essa nova classe de DOC mais DPF é denominada filtro catalítico de particulados diesel (CDPF, sigla em inglês) $)^{36}$. A oxidação do $\mathrm{CO}, \mathrm{HC}$ e da fração orgânica do material particulado contribui para elevar a temperatura do gás de escapamento antes dele chegar ao DPF. Além do aquecimento, o DOC pode também contribuir para a regeneração do DPF por meio da geração do $\mathrm{NO}_{2}$, que é capaz de oxidar o material depositado no DPF a temperaturas mais baixas $\left(>200^{\circ} \mathrm{C}\right)$. No entanto, para gerar maior aquecimento e $\mathrm{NO}_{2}$, é necessário utilizar-se um DOC com maior teor de metais nobres e, consequentemente, pelos motivos anteriormente expostos, convém que o CDPF seja utilizado com um diesel de baixo teor de enxofre.

Os principais ganhos obtidos com DPFs são, conforme literatura, as reduções de cerca de $80 \%$ de $\mathrm{CO}$ e $\mathrm{HC}$ e de $70 \%$ a $90 \%$ de material particulado. Já os CDPFs alcançam reduções de até cerca de $90 \%$ de CO e HC e de $99 \%$ de material particulado. DPFs também estão sujeitos a

\footnotetext{
${ }^{36}$ Algumas boas animações sobre o aspecto físico e a operação do CDPF e do SCR podem ser vistas em <http://ect.jmcatalysts.com/animation-crtandscrt.htm>, acessado em 24/7/2013.
} 
deterioração, sendo que no caso dos CDPFs aplicam-se as mesmas restrições do DOC. Os custos usualmente divulgados dos DPF e CDPF são significativamente superiores aos do DOC. O princípio da redução catalítica seletiva (SCR, sigla em inglês) baseia-se na nebulização de uma solução de ureia $\left(\left(\mathrm{NH}_{2}\right)_{2} \mathrm{CO}\right)$ nos gases de escapamento, a qual gera amônia $\left(\mathrm{NH}_{3}\right)$ que opera como agente redutor químico dos $\mathrm{NO}_{\mathrm{X}}$, transformando-os em $\mathrm{N}_{2}$. Para acelerar as reações químicas, que são significativamente mais lentas que as de oxidação, utilizam-se catalisadores mais volumosos, compostos de zeólitos de ferro ou cobre, ou de vanádio. Apesar deste último ter algumas vantagens, seu uso vem sendo questionado em função do risco da emissão de óxidos de vanádio ${ }^{37}$.

Como o rendimento térmico dos motores e a geração de $\mathrm{NO}_{\mathrm{X}}$ são tanto maiores quanto maior for a temperatura de combustão, o uso do SCR, que abate $\mathrm{NO}_{\mathrm{X}}$ externamente ao motor, permite que, sem as restrições dessa emissão, a eficiência dos motores seja otimizada, o que resulta em motores mais econômicos e menor emissão de gases de efeito estufa. Outra vantagem do SCR é que ele, em sua versão mais básica, pode operar com óleo diesel com teor de enxofre mais elevado, como por exemplo, 500 ppm (S500).

As primeiras desvantagens do SCR são a necessidade de se implantar uma infraestrutura para a distribuição da ureia e os custos adicionais associados a esse fato. Além disso, como a ureia tem um custo não desprezível, é necessário dispor de mecanismos que assegurem que ela seja de fato utilizada, o que é feito, em geral, por meio do uso de sensores especiais incorporados ao controle do motor. Infelizmente, esses sensores encarecem ainda mais a aplicação do SCR e não eliminam completamente o risco de que esse sistema de controle possa ser burlado.

O SCR foi inicialmente concebido para uso industrial. Sua aplicação veicular é mais complexa em função da variabilidade de regimes de operação dos motores de combustão, o que dificulta a dosagem e a homogeneização da solução de ureia. Caso essas não sejam feitas adequadamente, pode ocorrer à emissão de amônia, composto tóxico. As medidas para se reduzir esse risco são:

- Sofisticar os sistemas de controle de injeção da solução de ureia e do motor, de forma a aprimorar a eficácia e a sua sincronização.

- A adição de um catalisador de oxidação após o catalisador SCR, capaz de oxidar a amônia (“ammonia slip catalyst”).

\footnotetext{
${ }^{37} \mathrm{O}$ uso do vanádio é proibido no Japão e está sendo discutido nos Estados Unidos.
} 
- A introdução de sensores capazes de detectar a eventual emissão de amônia.

Visando reduzir o volume do catalisador SCR, é usual também se adicionar um catalisador de oxidação a montante do $\mathrm{SCR}$. $\mathrm{O} \mathrm{NO}_{2}$ nele gerado auxilia o processo de redução química dos $\mathrm{NO}_{\mathrm{X}}$. Entretanto, o uso simultâneo de DOCs, pelos motivos já expostos anteriormente, demandam óleos diesel de baixo teor de enxofre. Consequentemente, essas soluções mais complexas de SCR são viáveis somente em países que dispõem desse óleo diesel.

No Brasil, em função da atual proposta de progressão para a introdução do óleo diesel de baixo teor de enxofre e do risco de envenenamento dos catalisadores sensíveis a teores de enxofre mais elevados, os fabricantes vêm utilizando as versões mais básicas do SCR.

O catalisador adsorvedor de $\mathrm{NO}_{\mathbf{X}}$ (LNT, sigla em inglês) é capaz de reter até $90 \%$ do $\mathrm{NO}_{\mathrm{X}}$ gerado durante a operação normal dos motores diesel (mistura pobre). No entanto, posteriormente o $\mathrm{NO}_{\mathrm{X}}$ retido precisa ser reduzido quimicamente para $\mathrm{N}_{2}$, o que pode ser feito, por exemplo, por meio do enriquecimento dos gases de escape por períodos de 30 a 90 segundos. O potencial desta solução ainda está sendo avaliado quanto a aspectos como os mecanismos de regeneração, dessulfurização e degradação. O desempenho do LNT pode ser também melhorado se precedido por um DOC.

\section{Transmissão}

Juntamente com os motores de combustão, a transmissão é o componente veicular que mais expressivamente evoluirá nos próximos anos. $\mathrm{O}$ aprimoramento das transmissões visando à redução do consumo veicular está sendo feito por meio do aumento do número de marchas. Dessa forma é possível manter os motores em regimes de operação mais favoráveis. Esse fato é mostrado na Ilustração 2.12. Nessa ilustração, os círculos indicam o ponto de operação e correspondente peso do consumo de um veículo rodando segundo o ciclo de teste mundial para veículos leves (WLTC, sigla em inglês), e as áreas representadas em azul indicam a correspondente região do mapa do motor onde ele é mais eficiente, isto é, consumo específico (BSFC, sigla em inglês) inferior a $240 \mathrm{~g} / \mathrm{kWh}$. Comparando os dois gráficos, é fácil concluir que um câmbio de noves marchas possibilita um maior número de pontos operando em regimes mais favoráveis do motor. 

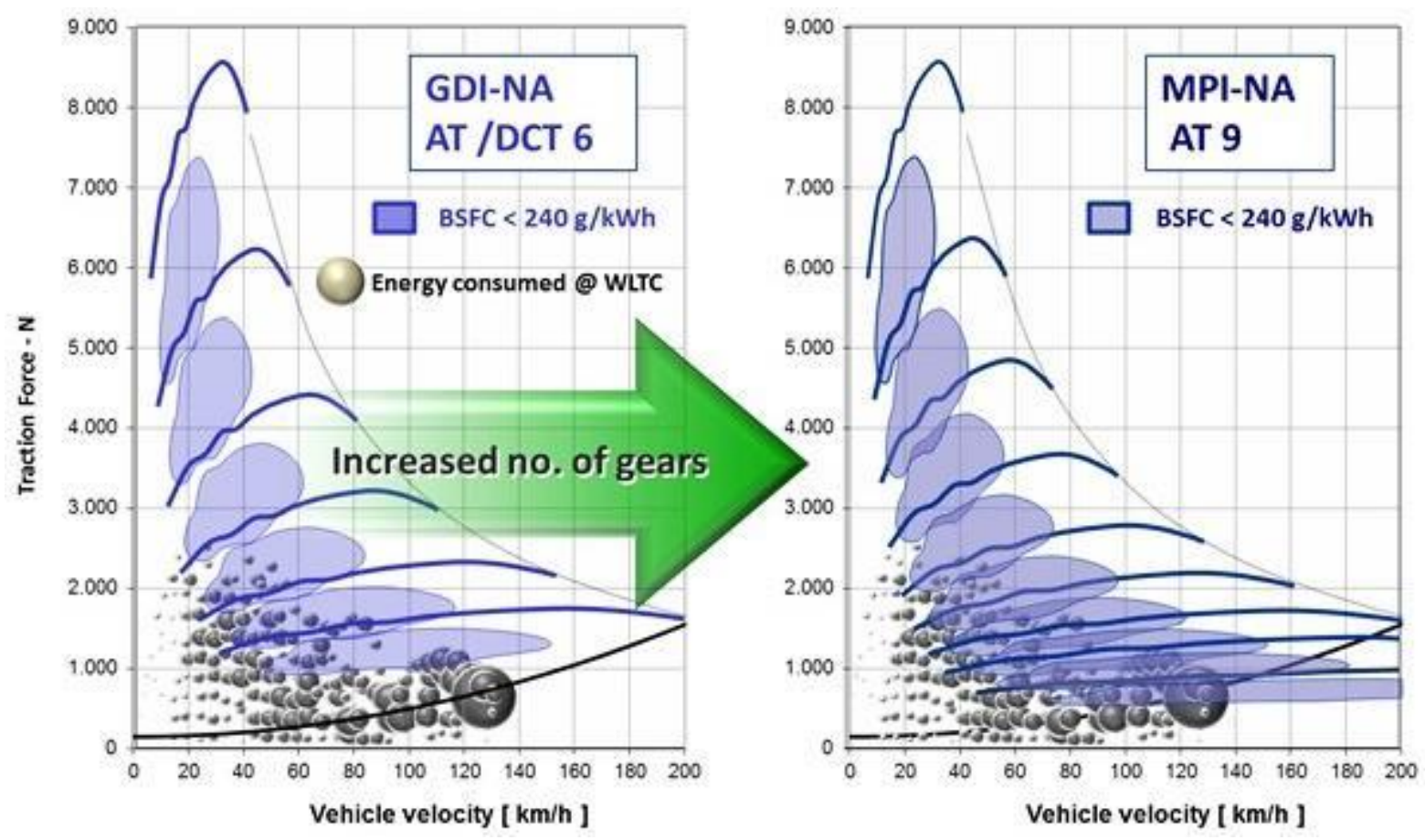

Ilustração 2.12 - Mapa de consumo de veículo no WLTC sobreposto aos regimes do motor operando com dois diferentes tipos de transmissão automática.

Fonte: Slide 26 da apresentação de FAIDL, G. "Market \& technology trends passenger car power train”, 2013.

Esse fato leva a empresa de consultoria "Information Handling Services" (IHS) a prever o volume de transmissões por número de marchas mostrada na Ilustração 2.13.

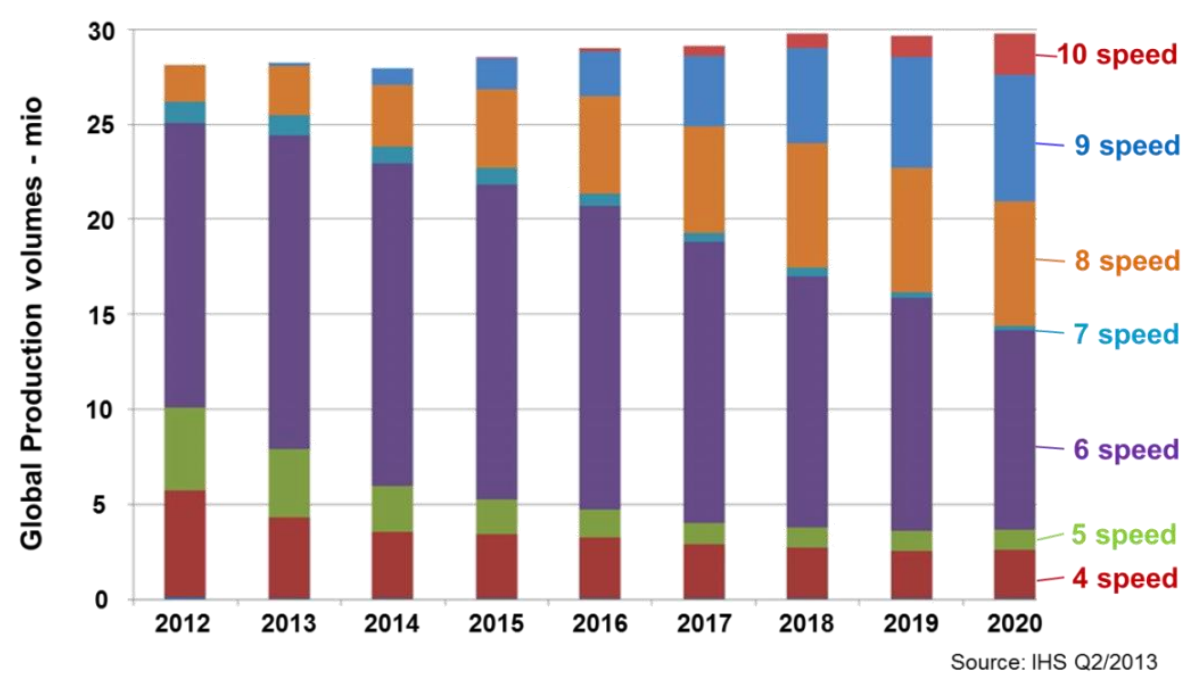

Ilustração 2.13 - Previsão do volume de vendas de transmissões por $n^{\circ}$ de marchas.

Fonte: Slide 27 da apresentação de FAIDL, G. “Market \& technology trends passenger car power train", 2013.

As transmissões automotivas existentes são classificadas como: manual (MT, sigla em inglês); semiautomática ou manual automatizada (AMT, sigla em inglês); semiautomática com dupla embreagem (DCT, sigla em inglês); automática (AT, sigla em inglês); continuamente variável 
(CVT, sigla em inglês); variável elétrica (EVT, sigla em inglês) ${ }^{38}$. Como pode ser visto na Ilustração 2.14, a participação no mercado de cada uma delas varia significativamente conforme a região. Observar também que, apesar de hoje algumas serem bastante incomuns, a IHS prevê um grande crescimento de sua participação em certas regiões. Entretanto, o mercado brasileiro pouco muda a exceção de uma ligeira maior penetração da CVT.
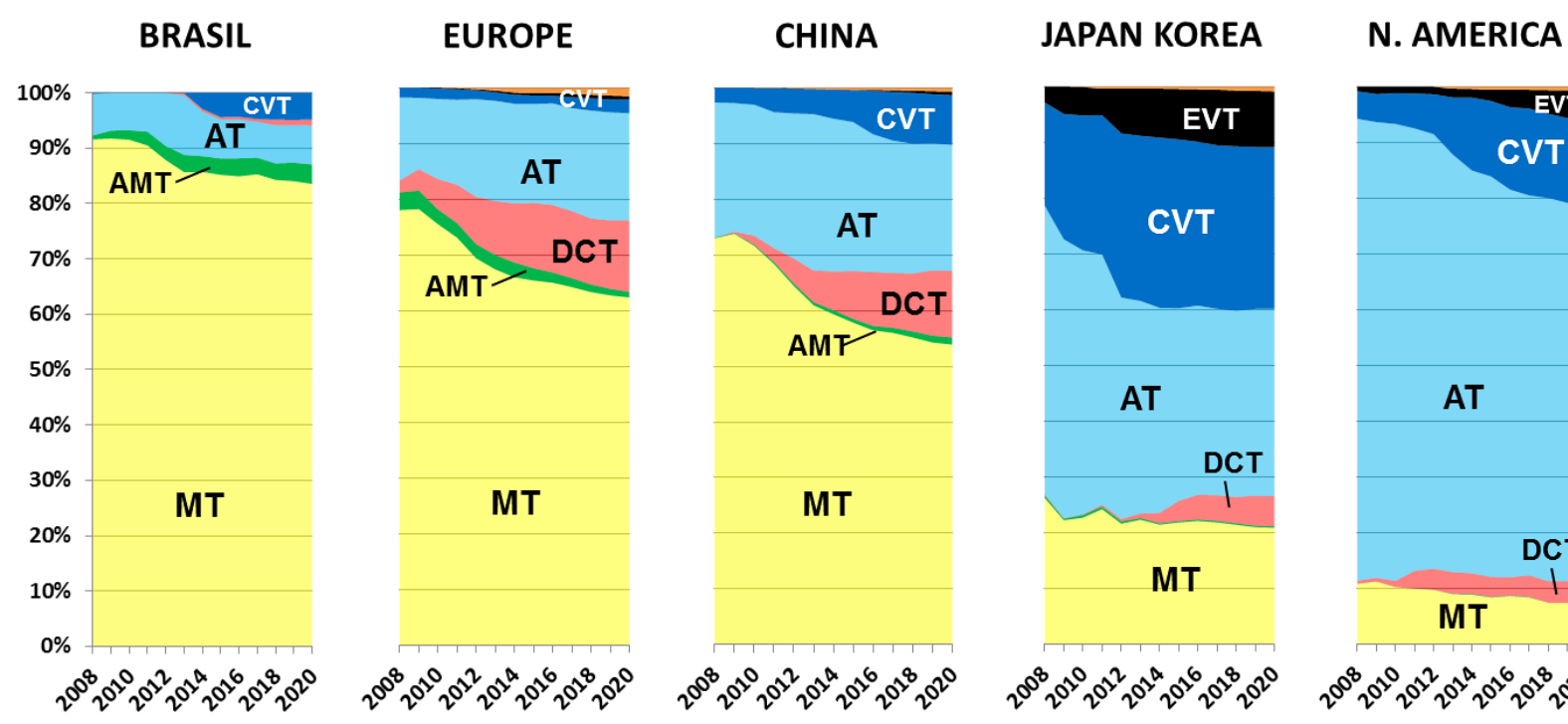

\section{Ilustração 2.14 - Participação nas vendas dos tipos de transmissões por região.}

Fonte: Slide 15 da apresentação de FAIDL, G. "Market \& technology trends passenger car power train”, 2013.

Um importante aspecto a realçar é que essas diferenças entre as regiões indicam não somente tendências mercadológicas vinculadas às transmissões, mas no curto prazo também apontam as tecnologias veiculares com maiores chances de sucesso na região. Como destaca Faidl (2013), as características da transmissão preferidas determina o tipo de motor de combustão que deve ser utilizado. Por exemplo, os mercados japonês e coreano preferem transmissões com transição suave, típica do CVT, com a aceleração do veículo sendo feita a custa de uma grande elevação da rotação do motor. Isso favorece o desenvolvimento de motores com requisito de torque moderado, típico dos motores a gasolina naturalmente aspirados com altas taxas de compressão e baixos picos de pressão e, consequentemente, menores atritos internos. Já o mercado europeu prefere transmissões com uma característica mais linear entre a rotação do motor e a velocidade do veículo, o que requer motores com torques elevados, típico dos motores GDI ou do ciclo Diesel com turbo compressores, com elevados picos de pressão e maiores atritos internos.

\footnotetext{
${ }^{38}$ Em linhas gerais, EVT é uma transmissão automática com um motor elétrico acoplado à engrenagem solar que, também acionado pelo motor elétrico, é capaz de operar como um CVT. É a transmissão do Toyota Prius.
} 


\section{Redução da massa dos veículos}

Segundo Heywood (2010), nos Estados Unidos, exceto nos anos de crise do petróleo de 1976 e 1982, constata-se que a massa média dos veículos leves, ponderada pelo número de veículos vendidos, vem crescendo a razão de $1 \%$ ao ano desde 1980, tendência que se espera seja revertida em função das novas legislações que restringem o consumo dos veículos. Não foi localizado um estudo brasileiro similar, mas não é difícil intuir que a massa média dos veículos leves nacionais também cresceu. Isso vem ocorrendo em parte devido ao crescente número de sistemas adicionados para incrementar o conforto e segurança dos veículos, e em parte pelo crescimento do porte médio dos veículos.

Heywood estimou o efeito da redução da massa de automóveis e comerciais leves no consumo por meio do programa de simulação do desempenho de veículos (AVL Advisor®). Mantendose tamanho e desempenho, para cada $1 \%$ de massa reduzida resulta em uma redução de consumo de cerca de $0,7 \%$. Esse número é coerente com o de outros estudos levantados por esse autor, que variam de $0,45 \%$ a $0,8 \%$. É preciso frisar que essa relação não é direta porque depende de outras características do veículo e da condição de uso típicas.

Para um determinado tipo de veículo, a redução de massa pode ser feita pela utilização de materiais mais leves ${ }^{39}$ ou por meio do aperfeiçoamento de seu projeto, ou ainda, quando possível, pela redução do porte do veículo e de seus componentes. Muitas vezes essas estratégias se processam concomitantemente. A redução da massa do veículo possibilita o uso de motores e periféricos menores, os quais por sua vez também possibilitam a redução da massa dos elementos estruturais.

Em função dessa análise, esse autor conclui que é possível reduzir a massa dos automóveis de $9 \%$ a $12 \%$, e dos comerciais leves e dos utilitários esportivos (SUV, sigla em inglês) em torno de $20 \%$, o que implicaria em uma redução de consumo da cerca de $7 \%$ e $15 \%$ respectivamente. Entretanto, convém lembrar que os automóveis e os comerciais leves brasileiros são significativamente menores que os correspondentes estadunidenses.

\section{Aerodinâmica}

Entre as alternativas de curto prazo, o aperfeiçoamento do desenho dos veículos, buscando a redução do coeficiente de forma ou coeficiente de arrasto aerodinâmico e, se possível, da área

\footnotetext{
${ }^{39}$ Segundo esse autor, atualmente uma das opções mais custo efetiva para esse fim é a utilização de aços de alta resistência (HSS, sigla em inglês).
} 
frontal do veículo ${ }^{40}$, é a mais custo efetiva. Mas isso depende do tipo de veículo e o estágio de desenvolvimento da sua classe. Veículos de pequeno porte (ex. motociclos e automóveis compactos) e caminhões especializados (ex. caminhão betoneira) têm, em geral, um potencial de ganho mais limitado. Por outro lado, caminhões "estradeiros", sobretudo, os articulados têm um grande potencial. Isso pode ser feito por meio da introdução de defletores de teto; carenamento lateral e inferior; aerofólios ("spoilers") frontais; e extensores de cabine que reduzam o espaço entre o cavalo mecânico e a carreta, mesmo para os caminhões em uso. É também possível aprimorar a aerodinâmica de caminhões abertos por meio da adequada distribuição das cargas e o fechamento da caçamba com lona. Exemplos desses aperfeiçoamentos aerodinâmicos podem ser vistos na Ilustração 2.15. Destaque-se que muitos desses aperfeiçoamentos podem ser realizados mesmo nos caminhões em uso.

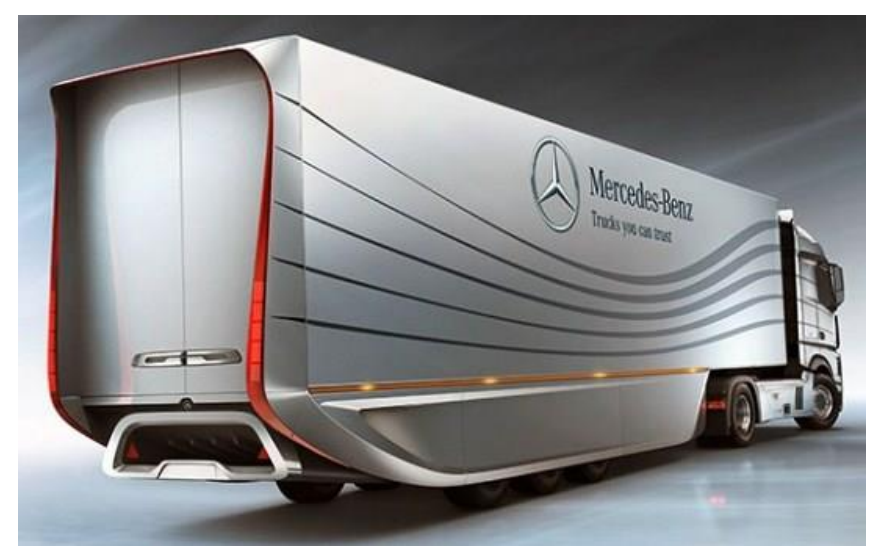

\section{Ilustração 2.15 - Exemplo do aperfeiçoamento aerodinâmico dos caminhões.}

Fonte: Daimler "World premiere: Mercedes-Benz Aerodynamics truck and trailer save fuel and relieve the burden on the environment", $2012^{41}$.

Não é comum divulgarem informações técnicas sobre a aerodinâmica dos veículos, mas com base em informações coletadas em fabricantes, a USEPA estima que a resistência aerodinâmica de automóveis possa ser reduzida em 20\% e de caminhões em 10\% (USEPA, 2008). Entretanto, como o efeito da resistência aerodinâmica no consumo depende significativamente da condição de uso, o impacto dessa redução na resistência aerodinâmica deve implicar em reduções de consumo de respectivamente $3 \%$ e $2 \%$ somente. No congestionado trânsito das cidades brasileiras, esse potencial de redução para os automóveis deve ser menor.

\footnotetext{
${ }^{40}$ Além destas grandezas, o arrasto aerodinâmico depende ainda, como já mencionado, da velocidade do veículo ao quadrado, a qual em princípio não se deseja alterar.

${ }^{41}$ Disponível em <http://media.daimler.com/dcmedia/0-921-657321-1-1533366-1-0-1-0-0-1-12639-0-0-3842-0-00-0-0.html?TS=1374412914934>. Acessado em 21/07/2013.
} 


\section{Pneus}

Segundo divulgado pelo Ministério de Energia estadunidense (USDOE) ${ }^{42}$, estima-se que a resistência ao rolamento seja responsável por de 5\% a $15 \%$ do consumo de combustível de veículos leves e de $15 \%$ a $30 \%$ de veículos pesados, números que dependem principalmente da condição de uso do veículo.

Em pistas lisas e rígidas, a resistência ao rolamento é causada, predominantemente, pela deformação dos pneus. Mas ela também é decorrente do escorregamento, dos esforços para execução de curvas, do atrito nos mancais das rodas e da deformação do piso ${ }^{43}$. Focando exclusivamente o pneu, os principais fatores que afetam a resistência ao rolamento são, além da pressão de calibragem, a estrutura, os compostos de borracha utilizados, a espessura e o desenho da banda de rodagem, e sua largura. Pneus mais leves e estreitos, com estrutura e compostos de borracha mais rígidos e com banda de rodagem menos espessa e desenho mais liso são mais econômicos.

Segundo a Green Seal (GREEN SEAL, 2003), os coeficientes de resistência ao rolamento de veículos leves variam de cerca de 0,01 a cerca de $0,006^{44}$, o que possibilita do pior ao melhor caso uma redução de consumo de até 3\%. Segundo estudo do NREL (CUDDY \& WIPKE, 1997), em veículos convencionais cada $1 \%$ de redução da resistência ao rolamento implica em $0,2 \%$ de redução de consumo, ou seja, um coeficiente de sensibilidade de 0,2. Ainda conforme divulgado pelo USDOE, esse valor é parcialmente corroborado por estudo da Comissão de Energia da Califórnia (CEC, sigla em inglês), que obteve coeficientes de sensibilidade de 0,08 a 0,19 dependendo do ciclo de condução normalizado empregado. Segundo estudo do Conselho Nacional de Pesquisas estadunidense (NRC, 2006), a reposição por pneus com resistências ao rolamento em média $10 \%$ menores possibilitaria de $1 \%$ a $2 \%$ de redução de consumo, redução que em termos nacionais teria um grande impacto.

No contexto estadunidense, essa redução média de $10 \%$, além de tecnicamente viável, é considerada custo efetiva, por considerarem que a troca por pneus mais eficientes se daria nos

\footnotetext{
${ }^{42}$ Conforme consta em <http://www.afdc.energy.gov/conserve/fuel_economy_tires_light.html>.

43 A deformação do piso é significativa no caso de solos macios. Pisos irregularidades aumentam a deformação dos pneus e causam vibrações na suspensão parcialmente dissipadas pelos amortecedores.

${ }^{44}$ A título de ilustração, a resistência ao rolamento das rodas de veículos pesados é da ordem de $70 \%$ da resistência daquela observada em veículos leves, e de veículos sobre trilho é da ordem de $10 \%$ da resistência daquela observada em veículos sobre pneus.
} 
períodos normais de reposição, não implicando em qualquer custo adicional para tanto. Os mesmos resultados dificilmente serão alcançados no Brasil, porque esses pneus são mais sensíveis às más condições das estradas brasileiras, o que restringe sua aplicação.

Visando o uso da pressão de calibragem correta dos veículos em uso, podem ser utilizados sistemas indicadores de pressão dos pneus ou ainda o calibrador automático de pneus, já comuns no mercado brasileiro. No entanto, exceto em frotas, é difícil estimar a eficácia que essas medidas teriam.

\section{Medidas específicas para caminhões}

Outras medidas verificadas eficazes pela USEPA ${ }^{45}$ especificamente para ônibus e caminhões são: treinamento dos motoristas; redução do tempo de operação em marcha lenta; eletrificação ou instalação de serviços dos pontos de parada, em substituição às unidades auxiliares de potência; e sistemas automáticos start-stop. Mais uma vez, exceto em frotas, é difícil estimar a eficácia que essas medidas teriam.

\subsubsection{Novas tecnologias veiculares}

A demanda por veículos cada vez mais econômicos e menos poluentes tem impelido à pesquisa e o desenvolvimento de novas tecnologias veiculares. A saber:

\section{Motores de combustão}

O primeiro passo a frente da tecnologia tradicional na busca por motores ciclo Otto para veículos leves mais eficientes foi o desenvolvimento da injeção direta de gasolina (GDI, sigla em inglês). Concebido em 1902, ele surgiu no mercado automobilístico a partir de 1996. E como demostram os gráficos a seguir, seu desenvolvimento em anos recentes tem sido expressivo. A Ilustração 2.16 exemplifica a evolução que ocorreu de 2005 a 2013 no desempenho a plena carga. Simultaneamente a um crescimento da pressão média efetiva (BMEP, sigla em inglês), medida da capacidade de realização de trabalho independente do porte do motor, de cerca de 30\%, obteve-se uma redução do consumo específico (BSFC, sigla em inglês) de aproximadamente $20 \%$, ou seja, um aumento de eficiência desta mesma ordem.

\footnotetext{
${ }^{45}$ Disponível em < http://www.epa.gov/smartway/>. Acessado em 21/07/2013.
} 


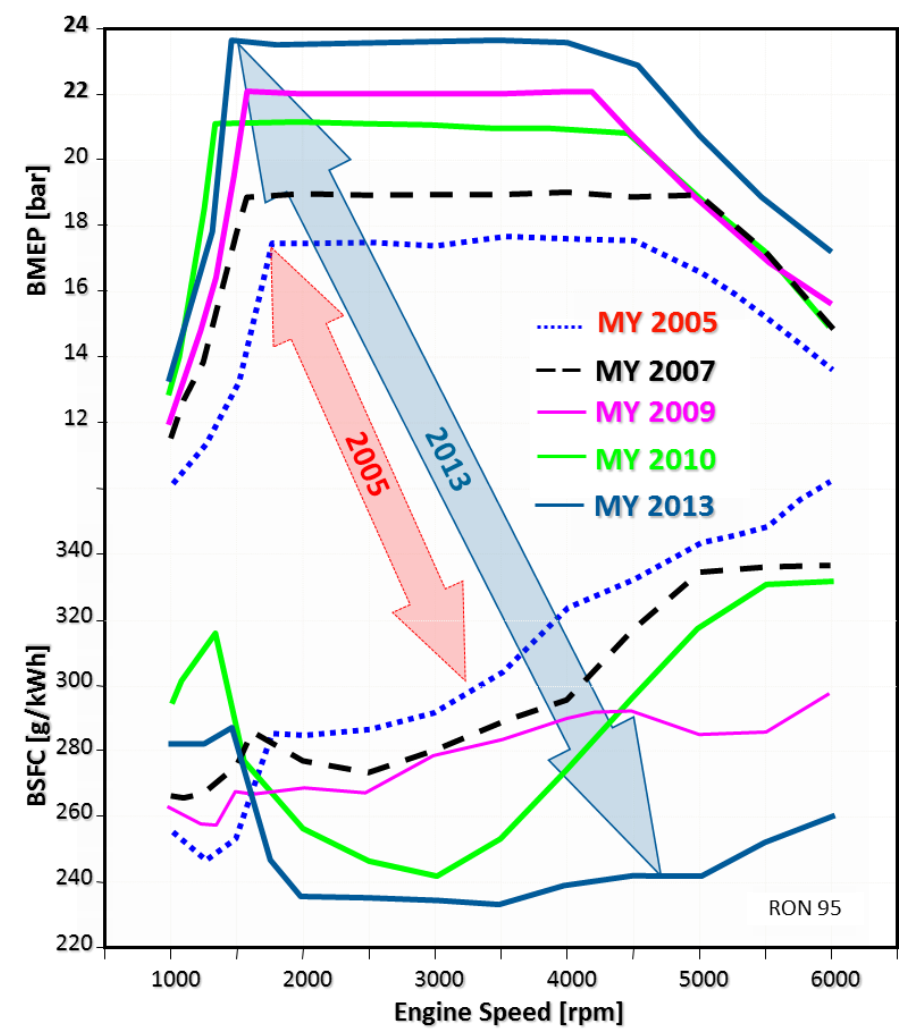

Ilustração 2.16 - Evolução recente dos motores GDI a plena carga.

Fonte: Slide 44 da apresentação de FAIDL, G. "Market \& technology trends passenger car power train", 2013.

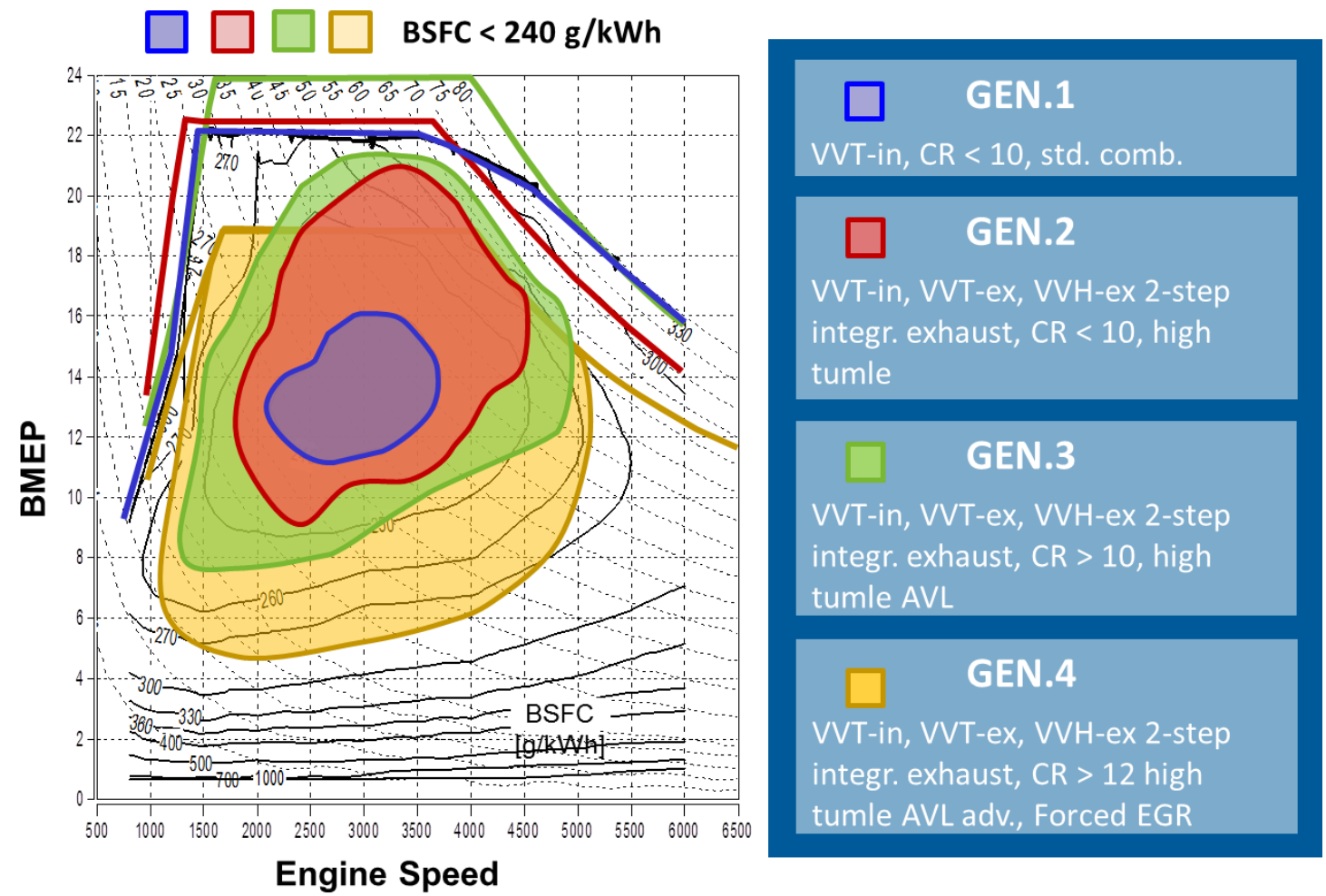

Ilustração 2.17 - Evolução da eficiência dos motores GDI em carga parcial

Fonte: Slide 53 da apresentação de FAIDL, G. "Market \& technology trends passenger car power train", 2013. 
Essa evolução também se reflete em cargas parciais. E como se pode observar na Ilustração 2.17, à medida que novas soluções tecnológicas são introduzidas no GDI, a área do mapa do motor com consumo específico inferior a $240 \mathrm{~g} / \mathrm{kWh}$ também é ampliada, o que propicia maior eficiência nas condições de operação típicas do motor no veículo.

Essa evolução tem decorrido do uso de comando de válvulas variáveis (VVT, sigla em inglês) mais sofisticadas, crescentes taxas de compressão, recirculação de gases de escapamento (EGR, sigla em inglês) e o uso de turbo compressor. Estas novas gerações que utilizam de turbo compressor são em geral identificadas pelas siglas TGDI ou GTDI (siglas em inglês). Exemplos dos ganhos dessas novas gerações são apresentados na Ilustração 2.18.

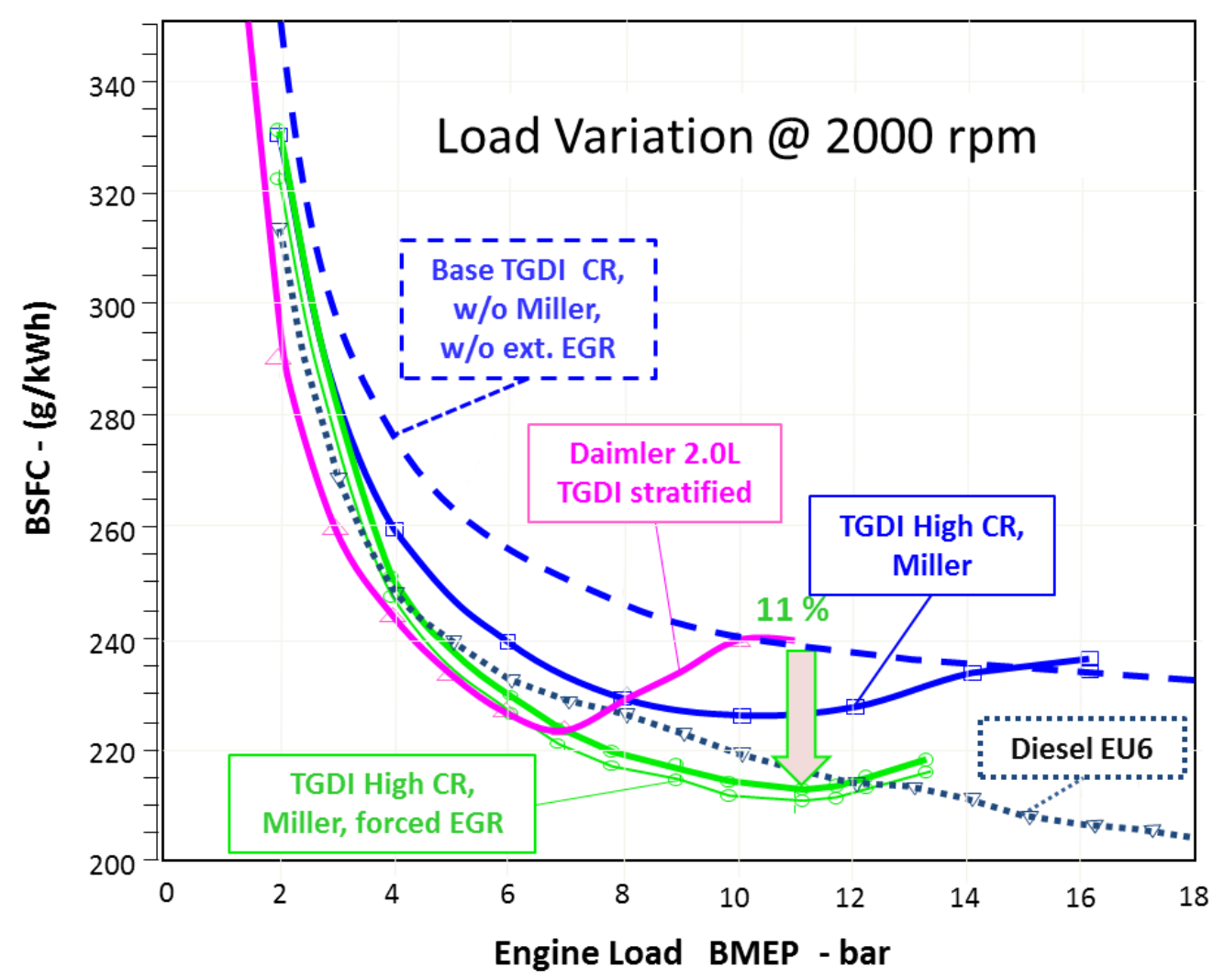

\section{Ilustração 2.18 - Curvas das novas gerações de motores.}

Fonte: Slide 51 da apresentação de FAIDL, G. "Market \& technology trends passenger car power train", 2013.

Consequentemente, como mostrado na Ilustração 2.19, a participação do GDI no mercado tem crescido e a IHS prevê que em breve ele dominará o mercado de motores Otto, principalmente na Europa e América do Norte. A empresa AVL estima que sua participação no mercado brasileiro poderá chegar a $10 \%$ em 2020. 


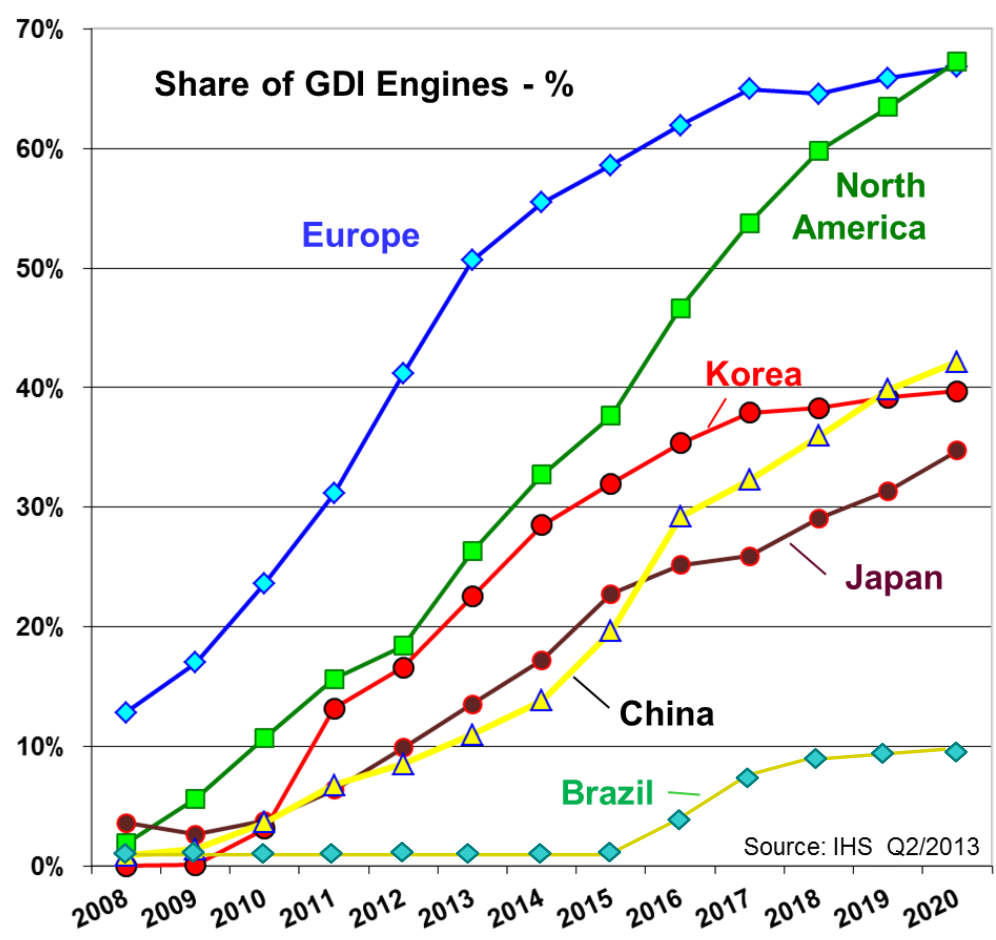

\section{Ilustração 2.19 - Previsão da participação nas vendas de motores GDI.}

Fonte: Slide 42 da apresentação de FAIDL, G. "Market \& technology trends passenger car power train", 2013.

Estão sendo aperfeiçoados também motores operando segundo os ciclos Atkinson e Miller. O que difere o ciclo Atkinson, concebido em 1882, do ciclo Otto, é que o primeiro possui uma fase de expansão estendida, o que pode ser obtido atrasando-se o fechamento da válvula de admissão, ou por meio de um sistema de virabrequins articulados, como mostrado na Ilustração 2.20, ou ainda em motores rotativos configurados para que isso aconteça. Em relação ao motor ciclo Otto equivalente, a expansão estendida resulta em um ganho de eficiência energética, mas a menor carga de ar causa perda de potência. Motores desse tipo vêm sendo convenientemente utilizados em veículos híbridos, onde sua desvantagem é contrabalançada pela presença do motor elétrico. O ciclo Miller, patenteado em 1957, é semelhante ao ciclo Atkinson, porém nele a perda de potência, decorrente da menor carga de ar, é compensada por meio de um compressor mecânico ("supercharger") e um resfriador de ar ("aftercooler"). Apesar de já terem sido utilizados no passado $^{46}$, não se identificou nenhum veículo atual com motor ciclo Miller. No entanto, como pode ser visto na Ilustração 2.18, devido seu grande potencial para reduzir o consumo de veículos operando com combustíveis do ciclo Otto, ele continua a despertar interesse.

46 Vide <http://www.motivemag.com/pub/feature/tech/Motive_Tech_Miller_Time_-_The_Miller_Cycle_Engine_ Explained.shtml > e < http://www.greencarcongress.com/2006/01/subaru_introduc.html >, acessados em 20/7/2013. 


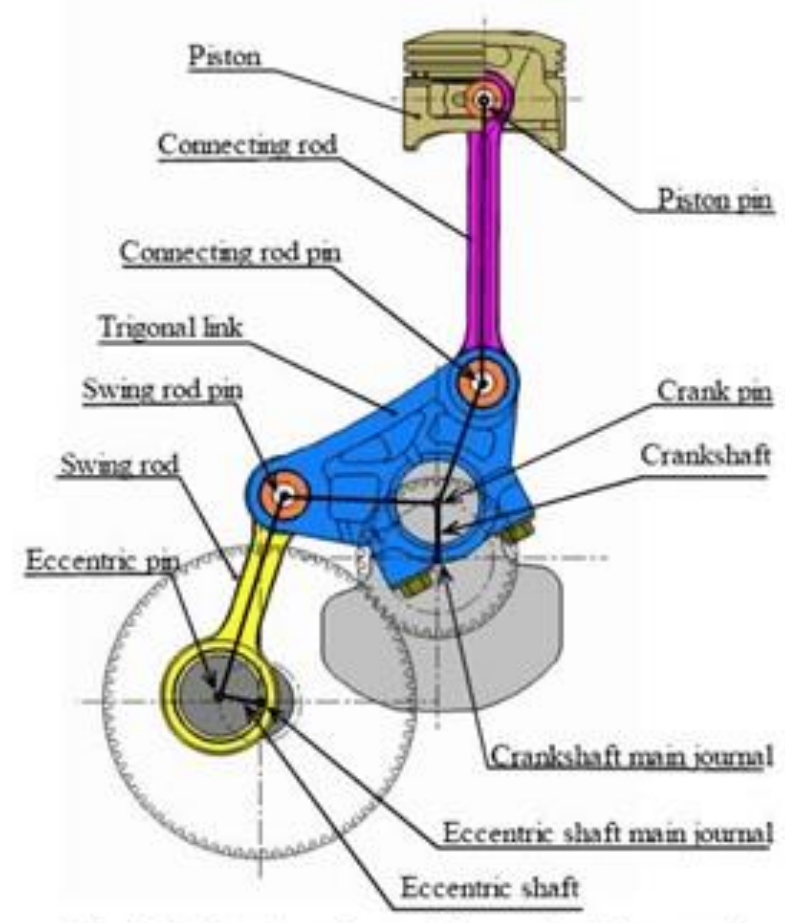

Fig. 3 Configuration of extended expansion linkage engine

\section{Ilustração 2.20 - Sistema de virabrequins articulados para Ciclo Atkinson.}

Fonte: Slide 50 da apresentação de FAIDL, G. "Market \& technology trends passenger car power train", 2013.

Outra alternativa é o motor de ignição por compressão de carga homogênea (HCCI, sigla em inglês). Esse motor opera com uma mistura ar-combustível homogênea, típica dos motores ciclo Otto, mas ao contrário deste, o início da ignição, ao invés de uma centelha, ocorre por compressão, como nos motores ciclo Diesel. O objetivo desse conceito é obter maior eficiência energética que a dos motores ciclo Otto e baixas emissões poluentes, sobretudo de $\mathrm{NO}_{\mathrm{X}}$ e $\mathrm{MP}$, por meio do uso de misturas pobres e taxas de compressão da ordem de 15:1. Espera-se com isso conseguir uma redução de consumo de cerca de 30\%. Além dos problemas tecnológicos associados aos elevados picos de pressão desse processo, o desafio do conceito é como controlar os diversos parâmetros que afetam a combustão, tais como a qualidade do combustível, temperatura e densidade da mistura após a compressão, em condições de carga e rotação transientes, de forma a assegurar a autoignição do combustível no momento desejado. Devido sua maior homogeneidade, o uso de etanol em motores HCCI seria vantajoso.

\section{Veículos elétricos}

No final da década de 80 e início da de 90, o foco do desenvolvimento da engenharia automobilística voltou-se para a questão da poluição ambiental. $\mathrm{Na}$ fronteira do desenvolvimento automotivo, a alternativa que parecia mais natural para enfrentar essa questão 
era o veículo elétrico, que apresenta emissões de gases poluentes e de ruídos praticamente nulas quando comparadas àquelas produzidas pelos motores de combustão dos veículos convencionais. Porém, ao contrário dos trólebus, desejava-se um veículo elétrico autônomo, capaz de operar independente da existência de uma rede elétrica dedicada, e os veículos elétricos à bateria (BEV, sigla em inglês, ou simplesmente $\mathrm{EV})$ passaram a ser a meta almejada. $\mathrm{Na}$ verdade, o impacto ambiental do BEV não é nulo. Depende de aspectos como o local de origem da energia elétrica e de sua forma de produção (ex. hidroelétricas, termo geração, etc.) e da tecnologia empregada, isto é, das técnicas de produção, dos materiais empregados e de sua reciclagem. O que reforça que uma comparação justa entre as opções de transporte só é possível por meio da análise do ciclo de vida.

As vantagens do BEV decorrem, em parte, do melhor rendimento energético e operação silenciosa dos motores elétricos. O maior torque a baixa rotação desses motores também pode possibilitar melhores acelerações e permite simplificar o projeto do sistema de transmissão. E a maior simplicidade do conjunto mecânico do trem de potência pode refletir positivamente no custo de sua manutenção. Esses motores também podem atuar como geradores durante a frenagem, facilitando a recuperação da energia de desaceleração. Porém, na prática, essa recuperação será somente parcial. Isso dependerá não somente do rendimento do esquema empregado, mas também do estado de carga das baterias. Em algumas situações, essa energia precisará ser dissipada em uma resistência. De qualquer forma, seja regenerativa ou não, a frenagem assistida diminui os esforços sobre o sistema de freio convencional do veículo, o que permite estender a vida útil deste.

Em função desse conjunto de características positivas, os BEVs são, em princípio, muito bem aceitos pelas comunidades, e atraentes a governos, sobretudo para sua aplicação em áreas ambientalmente mais críticas. Infelizmente, esses veículos também apresentam inúmeras desvantagens. Além se seu elevado peso, a densidade de energia das baterias é baixa quando comparada a dos combustíveis líquidos, o que na prática restringe significativamente a autonomia e o desempenho desses veículos. Seu uso também requer uma nova infraestrutura, sobretudo para seu "reabastecimento" (recarga das baterias), o que encarece seu custo operacional. Os tempos de recarga são relativamente longos, de 2 a 6 horas, dependendo do tipo de bateria utilizada. Soluções do tipo recargas distribuídas ao longo do $\operatorname{trajeto~}^{47}$ ou a

\footnotetext{
${ }^{47}$ Esse tipo de veículo é denominado veículo elétrico em linha (OLEV, sigla em inglês).
} 
substituição do conjunto de baterias do veículo são opções que encarecem ainda mais sua operação. Há também a necessidade de que o pessoal envolvido na operação e na manutenção dos veículos seja treinado para lidar com componentes elétricos de potência, o que não faz parte da cultura dos atuais operadores de frotas.

Resumidamente, a maior dificuldade para a disseminação desses veículos está em grande parte relacionada à tecnologia e o custo das baterias e, em um segundo plano, na falta de escala de produção. Apesar de toda pesquisa até hoje realizada, ainda não se obteve uma tecnologia de bateria que tornem esses veículos plenamente competitivos. Segundo a IEA (2009), sem um forte impulso dos governos para aumentar significativamente a competitividade dos veículos elétricos e para implantar infraestrutura adequada para sua recarga, dificilmente esses veículos se tornarão viáveis nos próximos dez anos. Será necessário incentivar o desenvolvimento de baterias de forma a reduzir seu custo para os fabricantes de equipamentos originais (OEM, sigla em inglês) dos atuais US\$ 500 a US\$ 800 por quilowatt-hora útil para US\$ 300 a US\$ 400 . Além disso, é fundamental aprimorar sua durabilidade, hoje muito aquém da durabilidade dos veículos, e constituir cadeia de suprimento de materiais compatível com a demanda que será criada.

Ainda segundo a IEA, também é necessário que a indústria automobilística compreenda melhor as necessidades e expectativas dos usuários, para que ela possa delinear seu potencial e desenvolver produtos apropriados para este mercado (modelos e preços). Além disso, em conjunto com os governos, eles terão que identificar e buscar soluções para as dificuldades que surgirão. Por exemplo, eles terão que instituir novos procedimentos de avaliação e padrões para esses veículos (ex. quesitos de desempenho e segurança) e componentes (ex. durabilidade das baterias). Para que BEVs e híbridos "plug-in", revistos a seguir, atinjam os 50\% de participação nas vendas em 2050, conforme previsto no "Blue map", é necessário que governos e indústria estabeleçam e realizem a meta de vender cinco milhões desses veículos mundialmente por ano.

Segundo levantamento do "Boston Consulting Group" (2011), se considerado somente o custo total de propriedade, mesmo considerando que o custo da bateria caia para US\$ 400 por quilowatt útil em $2020^{48}$, dificilmente o BEV será capaz de competir com o veículo convencional.

\footnotetext{
${ }^{48}$ Nessas condições, o custo da bateria de um BEV típico, com 20 kWh, será de U\$ 9600.
} 


\section{Veículos híbridos}

A dificuldade de se conseguir um BEV competitivo levou a indústria automobilística ao desenvolvimento do veículo híbrido (HV, sigla em inglês). Inicialmente, seu objetivo principal era atender a rigorosa legislação californiana de emissões tóxicas. Mas mais recentemente, o HV também se tornou uma alternativa para atender às metas de redução de consumo ou da emissão de GEE.

Existe uma diversidade de tecnologias híbridas de maior ou menor complexidade cuja eficácia depende, entre outras coisas, da própria condição de uso do veículo. Tipicamente, os HVs são veículos híbridos elétricos (HEV, sigla em inglês), que utilizam como fontes de energia para sua propulsão o combustível de um motor a combustão e um acumulador de energia elétrica ${ }^{49}$, usualmente uma bateria eletroquímica. Alternativamente, pode-se ter no lugar do motor uma célula combustível, e, como acumuladores, capacitores elétricos ou volantes de inércia eletromecânicos ${ }^{50}$. Outra solução que começa a ser também ofertada no mercado é o veículo hidráulico híbrido (HHV, sigla em inglês), que utiliza no lugar dos componentes elétricos do HEV, seus correspondentes hidráulicos, como por exemplo, um acumulador hidráulicopneumático no lugar da bateria.

Um ponto a favor do desenvolvimento da tecnologia híbrida é seu interesse militar, não somente pela redução do consumo de combustíveis e correspondentes custos e demandas logísticas a estes associados, como também pelo fato deles poderem operar por algum tempo com seus motores de combustão desligados, tornando-os menos detectáveis a alguns sensores utilizados em sistemas de guiagem de mísseis e bombas "inteligentes" ". Parece razoável supor que pelo menos parte dessa tecnologia militar que está sendo desenvolvida será de alguma forma transferida para a área civil.

Resumidamente, os principais ganhos potenciais dos HEVs decorrem dos seguintes elementos:

- A presença do acumulador de energia e do fornecimento de pelos menos parte da potência de tração por um ou mais motores elétricos, permite a utilização de motores de combustão

\footnotetext{
${ }^{49}$ Nos Estados Unidos usualmente identificados por "Rechargeable Energy Storage System" (RESS).

${ }^{50}$ Exemplos dessa alternativa são alguns "Kinetic Energy Recovery System" (KERS), utilizados em carros de Formula 1, no Porsche 911 GT3 R Hybrid e em veículos da marca Jaguar. Mas algumas marcas, como a Volvo, também estão anunciando seu uso em veículos comuns, inclusive ônibus.

${ }^{51}$ Alguns desenvolvimentos dessa natureza vêm sendo divulgados pelo "US Army National Automotive Center NAC", a Força Aérea e outras agências estadunidenses.
} 
de menor porte, trabalhando em regimes mais uniformes e com cargas mais elevadas. Como já visto, nessa condição eles apresentam melhor rendimento térmico e, consequentemente, menor consumo de combustível, e de maneira geral, menores emissões de poluentes tóxicos. O uso de um motor de menor porte também resulta em menor perda por atrito, o que também favorece o consumo. Destaque-se que esses ganhos associados à condição de uso e ao porte do motor sempre existirão independentemente do tipo do motor empregado.

- A frenagem regenerativa que possibilita o reaproveitamento de parte da energia de frenagem e, consequentemente, a redução do consumo de combustível.

Somente parte da energia de frenagem pode ser reutilizada, primeiro, porque os híbridos também utilizam o sistema de freios convencional, sobretudo nas frenagens mais acentuadas. Segundo, porque há perdas de rendimento nos sistemas de freio regenerativo. Além disso, se o acumulador já estiver totalmente carregado, essa energia de frenagem proveniente do motorgerador elétrico precisará ser dissipada em uma resistência.

Não é difícil concluir que os HEVs são invariavelmente mais complexos e, consequentemente, caros que seus equivalentes convencionais. E, em função de sua maior complexidade e, sobretudo, da massa das baterias, são em geral também mais pesados, o que lhes reduz parte de suas vantagens.

HEVs podem ser projetados de forma a, em seu uso normal, utilizarem como única fonte de energia o combustível que será consumido pelo motor de combustão do veículo ("chargesustaining") ou, ainda, demandarem recargas dos acumuladores por outras fontes de energia externas ("charge-depleting"). Apesar do sucesso desses últimos dependerem mais da tecnologia de baterias, devido ao menor custo da energia elétrica em relação aos derivados de petróleo, sua oferta no mercado norte-americano, onde são chamados de veículos híbridos "plug-in" (P2 (PHEV, sigla em inglês), vêm crescendo.

Os sistemas híbridos podem ainda ser em série ou em paralelo. Há ainda uma versão que incorpora as funções de ambos e que é identificada de diferentes maneiras: híbrido combinado, híbrido misto ou, mais usualmente, "full hybrid".

No híbrido em série, a tração é realizada exclusivamente por um ou mais motores elétricos acoplados à transmissão. $\mathrm{O}$ motor de combustão tem com única função acionar o gerador

\footnotetext{
${ }^{52}$ PHEVs são HEVs com baterias de maior capacidade, que podem ser abastecidas na rede elétrica, e menores motores de combustão, projetados para rodar principalmente no modo elétrico.
} 
elétrico, cuja energia, quando necessária, é utilizada ou para mover os motores elétricos de tração ou para recarregar o acumulador de energia elétrica ou, se a condição de uso do veículo permitir, uma combinação dos dois. Para tracionar o veículo, via motor elétrico, a energia demandada pode provir ou do gerador ou do acumulador ou, nas condições de maior demanda (veículo carregado, acelerações severas e subidas de rampa) dos dois simultaneamente. Na frenagem, o motor elétrico pode operar como gerador e contribuir para carregar o acumulador, condição que caracteriza a frenagem regenerativa.

Esses veículos necessitam de um acumulador, tipicamente um conjunto de baterias, de maior capacidade, que devido a seu peso acaba penalizando o consumo de combustível e a dirigibilidade do veículo. Outra característica do híbrido em série é a perda de eficiência energética devido ao maior número de conversões de energia, o que também penaliza o consumo. Por outro lado, nesse veículo é mais fácil manter o motor de combustão em uma condição de operação mais favorável, de melhor rendimento térmico e, portanto, de menor consumo e de menores emissões poluentes.

No híbrido em paralelo, o veículo pode ser tracionado tanto pelo motor elétrico como pelo motor de combustão, ou pelos dois simultaneamente. Para tanto, ele precisa ter um sistema de transmissão que possibilite essa operação simultânea dos motores elétrico e de combustão. Ao contrário do que ocorre no híbrido em série, nesse caso é mais difícil manter o motor de combustão na condição ideal de operação, o que em geral acarreta em maiores consumo e emissões poluentes ${ }^{53}$.

Os sistemas híbridos em paralelo são também subdivididos em "mild hybrid" e "full hybrid", mencionado anteriormente. O veículo "mild hybrid" tem somente um motor/gerador elétrico. Ele opera como motor somente para auxiliar o motor de combustão na tração quando há uma maior demanda de potência. Como há somente um, quando operando como gerador para recarregar as baterias, ele não pode auxiliar a tração. Comparados aos veículos "full hybrid", são veículos potencialmente mais simples e de menor custo. Os "mild hybrids" são também subdivididos de acordo com as menores ou maiores capacidades do sistema híbrido, refletidas em sua voltagem de operação, em híbridos de baixa tensão ou de alta tensão. São exemplos de veículos “mild hybrids" os modelos Insight e Civic da marca Honda.

\footnotetext{
${ }^{53}$ Um bom diagrama animado sobre o esquema de funcionamento de um veículo híbrido paralelo pode ser visto em http://www.fueleconomy.gov/feg/hybridAnimation/swfs/hybridframe.html>, acessado em 15/7/2013.
} 
O veículo "full hybrid", mais bem caracterizado como híbrido combinado, possui um motor elétrico e um gerador, o que lhe permite operar como série ou paralelo. Isto é, ele é capaz de simultaneamente gerar, via gerador e motor de combustão, e consumir energia elétrica, via motor elétrico. O motor elétrico tem capacidade de, independentemente do motor de combustão, mover o veículo, o que ocorre em geral nas baixas demandas de potência, por exemplo, em acelerações suaves ou a velocidades constantes. Este é o caso, por exemplo, do HEV mais bem sucedido no mercado, o Toyota Prius, atualmente em sua terceira geração.

O objetivo dessa configuração é obter o melhor que cada um dos sistemas série e paralelo oferece, como baixo nível de emissões, pela operação do motor de combustão mais próximo das condições ideais, e um acumulador de menor capacidade, consequentemente menor peso.

Essas diferenças são muitas vezes subjetivamente referenciadas como "grau de hibridização". Quanto maior o número de funções disponíveis, que em ordem crescente de dificuldade de implantação, são: desligamento do motor durante a condição de marcha lenta; freio regenerativo; tração assistida por motor elétrico e tração elétrica; e maior relação da potência elétrica sobre a potência mecânica do motor de combustão, maior será o "grau de hibridização". A Tabela 2.7 abaixo apresenta as principais características das diferentes configurações de HEVs.

Tabela 2.7 - Quadro comparativo das principais características dos diferentes híbridos.

\begin{tabular}{cccccc}
\hline Item & Micro hybrid & $\begin{array}{c}\text { Micro/mild LC } \\
\text { Super Hybrid }\end{array}$ & Mild hybrid & Full hybrid & $\begin{array}{c}\text { Plug-in } \\
\text { hybrid }\end{array}$ \\
\hline Voltagem & $12 \mathrm{~V}$ & $12-48 \mathrm{~V}$ & $24-130 \mathrm{~V}$ & $200-270 \mathrm{~V}$ & $300-400 \mathrm{~V}$ \\
$\begin{array}{c}\text { Potência regen. } \\
\text { Autonomia na }\end{array}$ & $0,5 \mathrm{a} 3,0 \mathrm{~kW}$ & $3 \mathrm{a} 8 \mathrm{~kW}$ & $\sim 10 \mathrm{~kW}$ & $\sim 20 \mathrm{~kW}$ & $>20 \mathrm{~kW}$ \\
$\begin{array}{c}\text { eletricidade } \\
\begin{array}{c}\text { Custo OEM } \\
\text { (estimado em US\$) }\end{array}\end{array}$ & 200 a 900 & 1000 a 2000 & 2100 a 4000 & 4000 a 6600 & 8000 a 13000 \\
$\begin{array}{c}\text { Benefício CO } 2 \\
\text { Custo OEM por }\end{array}$ & 4 a $7 \%$ & 15 a $25 \%$ & 8 a $15 \%$ & 15 a $30 \%$ & $>30 \%$ \\
$\begin{array}{c}1 \% \text { de benefício } \\
\text { (estimado em US\$) }\end{array}$ & 45 a 130 & 65 a 80 & 265 a 330 & 265 a 330 & 400 a 660 \\
\hline
\end{tabular}

Fonte: Quadro do prospecto da ALABC "Has the obvious been overlooked?", 2012. Disponível em <http://www.alabc.org/publications/lc-technology-has-the-obvious-been-overlooked/view>, acessado em $11 / 05 / 2013$.

Veículos que utilizam um gerador integrado ao motor de partida, o que lhes possibilita o desligamento do motor durante a marcha lenta e certo grau de frenagem regenerativa, apesar de disporem desses recursos dos híbridos, não são classificados como tais. 
Mais significativamente do que entre os veículos tradicionais, o melhor ou pior desempenho das alternativas existentes é fortemente influenciado pela condição de uso do veículo, a qual deve ser a base para seu desenvolvimento. De maneira geral, pode-se intuir que quanto mais intermitente a condição de operação do veículo e o tempo que ele opera em marcha lenta, como ocorre no trânsito urbano, maiores serão os benefícios do uso da tecnologia híbrida e a justificativa para utilizar um maior "grau de hibridização". Por outro lado, se a condição de uso do veículo for mais uniforme, como a que ocorre tipicamente nas estradas, menores serão seus ganhos e a justificativa para seu uso. Um veículo convencional, otimizado para operar em uma determinada velocidade uniforme, devido ao grande rendimento de uma transmissão mecânica, pode apresentar um rendimento energético superior a dos híbridos. Além disso, o sucesso de um veículo híbrido está fortemente vinculado ao desempenho de seu sistema de controle para administrar os diversos fatores antagônicos envolvidos. Foram identificados casos nos quais, ao contrário do esperado, ocorreu o aumento do consumo e das emissões (IPT, 2007).

A atual participação dos HEVs tendo sido possível graças aos incentivos fiscais fornecidos pelos governos a esses veículos, sobretudo na América do Norte ${ }^{54}$. Isso associado ao fato do diesel custar mais do que a gasolina nessa região, torna os veículos híbridos leves mais populares ali do que na Europa. Mas já estão surgindo no mercado alguns modelos a diesel ${ }^{55}$.

A IEA estima que os HEVs possam atingir uma redução de consumo de combustível de 50\% em 2030. Caso essa redução se confirme, os HEVs se tornariam custo-efetivos para um preço de petróleo superior a US\$120 por barril (base 2010).

\section{Veículos a hidrogênio}

A grande vantagem do hidrogênio é sua contribuição praticamente nula ao efeito estufa em sua parcela do "tanque à roda" de seu uso veicular. Mas sob este ponto de vista, para confrontá-lo com outros combustíveis, é também necessário considerar os demais aspectos de seu ciclo de vida, envolvendo não somente sua produção, mas também sua distribuição e armazenamento, muito mais complexos do que a dos combustíveis líquidos. Além disso, todas as desvantagens

\footnotetext{
54 Maiores informações sobre os veículos leves ofertados nos Estados Unidos podem ser obtidas em <http://www.fueleconomy.gov/feg/hybrids.jsp> e em <http://www.hybridcars.com/>, acessados em 16/7/2013. Informações iniciais sobre ônibus e caminhões híbridos podem ser obtidas em <http://www.nrel.gov/ vehiclesandfuels/fleettest/research_hybrid.html > e em <http://www.calstart.org/Projects.aspx>, acessados em $16 / 7 / 2013$.

${ }^{55}$ Vide <http://blog.caranddriver.com/land-rover-to-bring-diesel-hybrid-range-rover-to-u-s-report-says/> e <http:// www.peugeot.com/en/products-services/cars/peugeot-3008-hybrid4>, acessados em 16/7/2013.
} 
do gás natural são ainda mais críticas no caso do hidrogênio: densidade energética, autonomia, volume e peso do reservatório, segurança, infraestrutura de produção e distribuição. O uso de reformadores veiculares para a obtenção de hidrogênio a partir de outros combustíveis, mesmo eliminando os problemas de distribuição e armazenamento desse combustível, praticamente não altera seu custo e torna sua utilização ainda mais complexa (THIJSSEN \& LASHER 2002). Seu uso em veículos pode se dar tanto por meio de motores de combustão como por meio de células a combustível, onde ele é convertido diretamente em energia elétrica. Neste último caso, visando aproveitar os melhores rendimentos das conversões elétricas, o produto mais típico é o veículo elétrico à célula a combustível (FCEV, sigla em inglês). A adição de um acumulador a esse veículo possibilita o freio regenerativo característico dos HEVs, resultando em um FCEV híbrido, configuração que parece ser a mais promissora.

Entre as diversas tecnologias de célula a combustível, a que se mostrou mais propícia para uso veicular foi a membrana de troca de próton (PEM, sigla em inglês). A eficiência dessa célula combustível em cargas parciais pode superar os 50\%, mas a plena carga é semelhante à dos motores de combustão (IEA, 2010). A despeito de todo o esforço que vem sendo empenhado para seu desenvolvimento, e apesar de em anos recentes se ter conseguido alguma redução de custo, os FCEVs são veículos de valores muito superiores aos convencionais, mesmo para o padrão de mercado dos países desenvolvidos. Consequentemente, sua penetração no mercado nacional é ainda mais improvável.

\section{Interface homem-máquina}

O desenvolvimento de tecnologia veicular que possibilita a redução do consumo e as emissões vai além dos aperfeiçoamentos já mencionados. É possível ainda implantarem-se sistemas que atuam na interface homem-máquina, orientando, automatizando ou mesmo restringindo o comportamento do motorista. Os exemplos mais comuns dessas tecnologias são aceleradores eletrônicos e os aparelhos de auxílio à navegação tipo GPS ${ }^{56}$, os identificadores ("tags") utilizados em pedágios eletrônicos, e, da união dessas duas tecnologias, os rastreadores (“transponders"), utilizados aqui no Brasil principalmente para coibir o roubo de veículos.

Aparelhos GPS, em função das características do trajeto e do terreno, podem indicar aos motoristas a forma de condução mais econômica em cada trecho da viagem (DAIMLER, 2009; SCANIA, 2011). E se conectados a um sistema de informação externo que disponha das

\footnotetext{
${ }^{56}$ Sigla em inglês de sistema de posicionamento global.
} 
condições de tráfego em tempo real, podem indicar as rotas mais rápidas e mais econômicas para alcançar um determinado destino ${ }^{57}$. Esse serviço já existe mesmo gratuitamente para "smartphones",58.

Além de sistemas de informação, há uma extensa lista de sistemas de auxílio aos motoristas disponíveis no mercado, ainda restritos a poucos modelos aqui no Brasil, alguns com pouca influência sobre o consumo ${ }^{59}$, mas outros que contribuirão definitivamente para a automação da direção ("self-driving vehicles"), matéria que já está sendo regulamentada pelos governos ${ }^{60}$. São eles: controle de distância do veículo à frente ("autonomous cruise control") ${ }^{61}$; sistema para mitigar colisões frontais ("precrash system")" ${ }^{62}$; alarme da manutenção da faixa de rolamento ("lane departure warning system") ${ }^{63}$; e controle da faixa de rolamento ("lane keeping assist") ${ }^{64}$, que somados possibilitam a automação da direção ("adaptive cruise control"), em breve disponível para congestionamentos ("automatic driving in traffic jams") ${ }^{65}$.

A popularização dos sistemas de automação da direção integrados a centrais de informação sobre o trânsito possibilitará a condução dos veículos e a seleção de rotas da forma mais otimizada possível, visando à redução do consumo e das emissões.

\subsubsection{Potencial da evolução da tecnologia veicular}

O Fórum Econômico Mundial (WEF, sigla em inglês) divulgou um trabalho onde, com base em estudos de diferentes entidades, é apresentado o potencial de ganho em curto prazo das diferentes tecnologias comercialmente disponíveis (WEF, 2011), conforme mostrado nas Ilustrações 2.21 e 2.22 .

\footnotetext{
${ }^{57}$ Por exemplo, <http://www8.garmin.com/traffic/> ou <http://www.tomtom.com/en_gb/services/live/hd-traffic/>, acessados em 13/7/2013.

${ }^{58}$ Vide <http://www.waze.com/>, acessado em 13/7/2013.

59 São exemplos dessas tecnologias: controle de estacionamento ("self-parking"), alarme lateral ("side assist"), controle dos faróis ("light assist"), alerta de sinais de tráfego ("sign assist"), ampliação do campo de visão ("area view"), sistema de detecção de fadiga do motorista ("fatigue detection system"), etc.

60 Vide, por exemplo, <http://www.nsf.gov/news/special_reports/science_nation/carswithoutdrivers.jsp> e <http://www.pcmag.com/article2/0,2817,2400400,00.asp>, acessados em 23/02/2012.

${ }^{61}$ Vide <http://en.wikipedia.org/wiki/Autonomous_cruise_control_system>, acessado em 23/02/2012.

${ }^{62}$ Vide <http://en.wikipedia.org/wiki/Precrash_system>, acessado em 23/02/2012.

${ }^{63}$ Vide <http://en.wikipedia.org/wiki/Lane_departure_warning_system>, acessado em 23/02/2012.

64 Vide <http://rb-kwin.bosch.com/en/safety_comfort/drivingsafety/capscombinedactivepassivesafety/thecaps functions/lanekeepingsupport.html > e <http://www.globaldensoproducts.com/dcs/lka/index.html >..

65 Vide <http://blog.caranddriver.com/we-go-for-a-ride-in-audis-piloted-driving-autonomous-a6-avant-prototype2013-ces/>, acessado em 23/02/2012.
} 


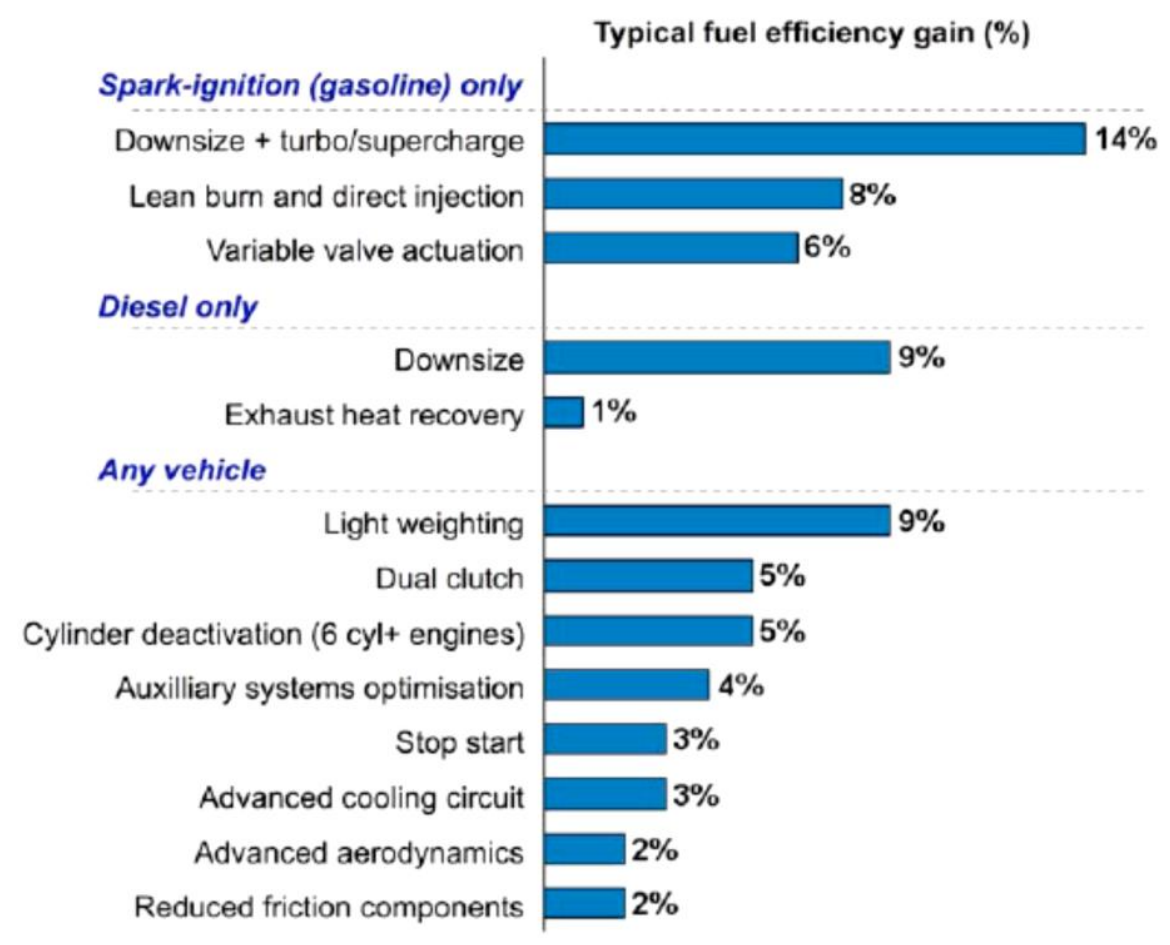
Ilustração 2.21 - Potencial de ganhos de eficiência energética para diferentes tecnologias aplicáveis a veículos leves.

Fonte: Ilustração 9 do artigo “Repowering Transport” do WEF, 2011.

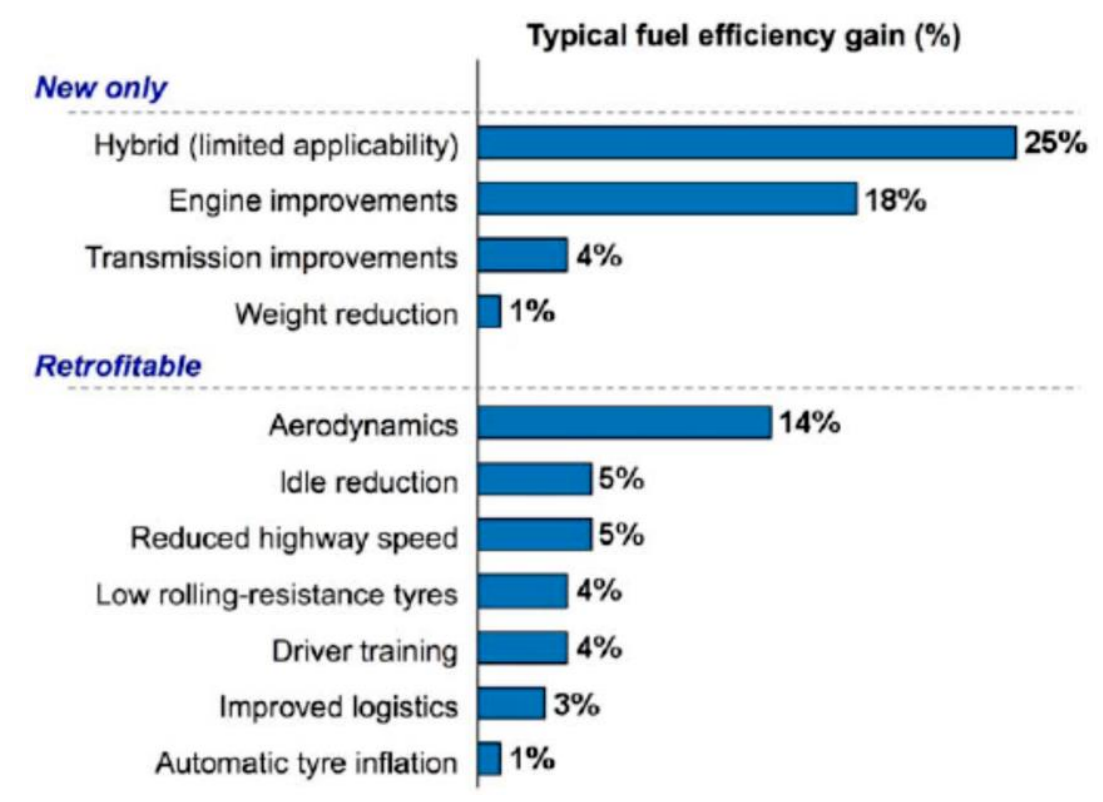

Ilustração 2.22 - Potencial de ganhos de eficiência energética para diferentes tecnologias e medidas aplicáveis a veículos pesados.

Fonte: Ilustração 12 do artigo "Repowering Transport" do WEF, 2011. 
Ressalve-se que nessas ilustrações os ganhos estão expressos em termos de ganho de eficiência que, como o próprio WEF destaca, é diferente de redução de consumo ${ }^{66}$. Naturalmente, em função de suas características típicas e diferentes condições de uso, verifica-se nessas ilustrações que há diferenças significativas entre os segmentos dos veículos leves e pesados, tanto no que se refere às tecnologias aplicáveis como de seus correspondentes ganhos potenciais. Observar que nem todas as tecnologias previamente revistas foram consideradas nesse trabalho. Essas diferenças também se manifestam nos diferentes segmentos dos veículos pesados, como pode ser visto na Ilustração 2.23.

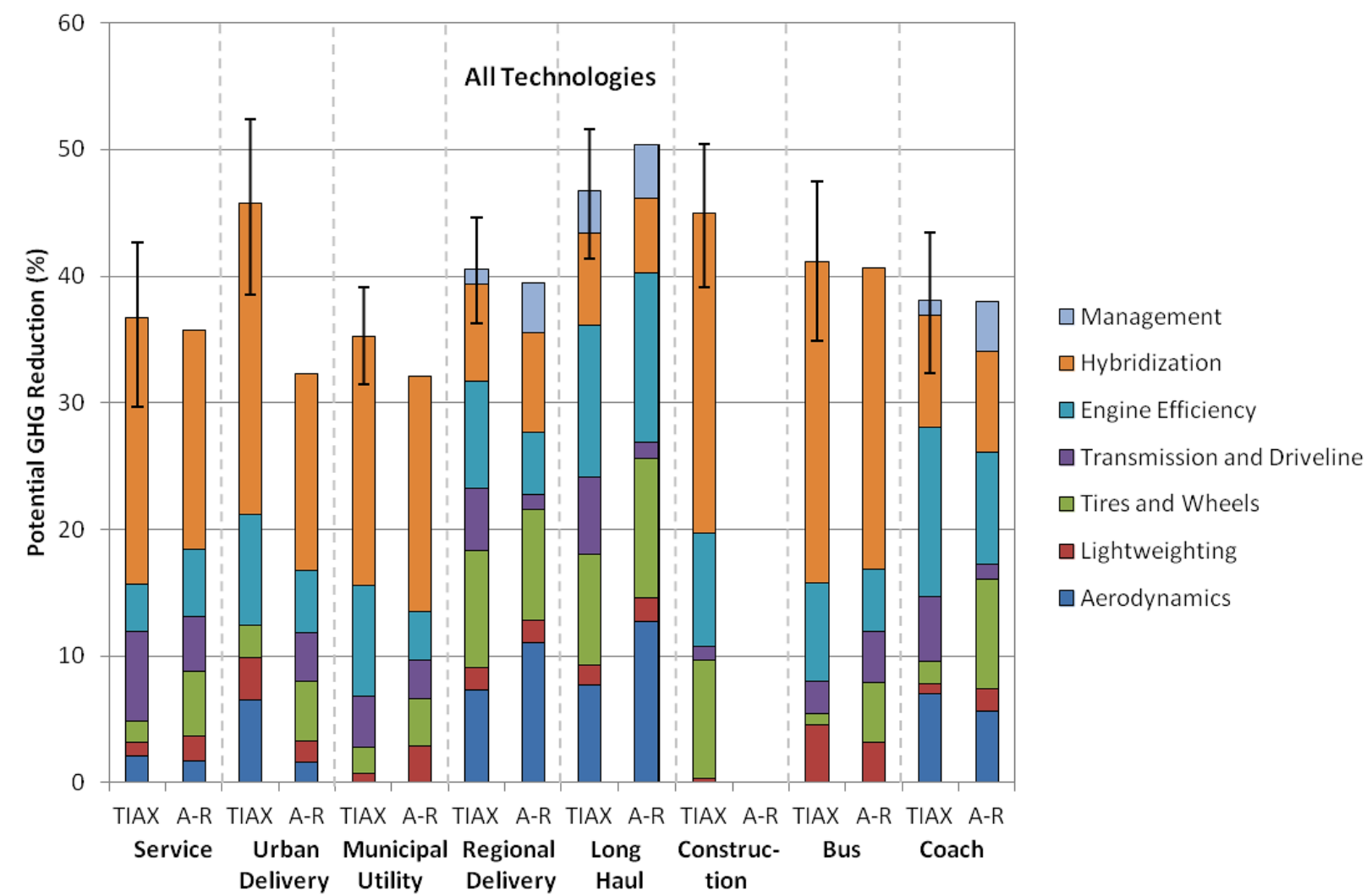

Nota: TIAX e A-R, na verdade Ricardo-AEA, referem-se às duas instituições que realizaram estudos dessa natureza, a primeira para o ICCT e a segunda para a Comissão Europeia.

Ilustração 2.23 - Potencial de redução de consumo das diferentes tecnologias aplicadas aos diferentes segmentos dos veículos pesados.

Fonte: Ilustração ES-1 do relatório "European Union Greenhouse Gas Reduction Potential for Heavy-Duty Vehicles", elaborado pelo TIAX para o ICCT, 2011.

Segundo a IEA (2010), a extensão da participação de novas tecnologias no mercado dependerá do custo e economia de combustível proporcionada em relação a seus concorrentes. Nesse estudo, a IEA prognosticou a penetração das tecnologias no mercado de veículos leves de

\footnotetext{
${ }^{66}$ Um aumento de eficiência de $100 \%$ implica em uma redução de consumo de $50 \%$.
} 
passageiros até 2050 para diferentes cenários. A evolução desse mercado e as participações assumidas para dois dos cenários considerados podem ser vistas na Ilustração 2.24. Chama a atenção nesse gráfico: o significativo crescimento do mercado projetado e da participação dos veículos híbridos e a gás, sejam GNV ou GLP, para qualquer dos dois cenários apresentados; e confrontando esses cenários, a grande incerteza quanto à participação dos BEVs e FCEVs.

Como também conclui o WEF, o cenário "business as usual" nos conduzirá a uma trajetória “claramente nem desejável nem social, econômica e ambientalmente sustentável”, e será necessário que todos os segmentos da sociedade se empenhem para a rápida adoção não somente de todas as tecnologias energeticamente mais eficientes, mas também da eletrificação dos transportes e combustíveis alternativos, mesmo que ainda não plenamente comerciais. $\mathrm{O}$ WEF estima que seja necessário de US\$ 200 a 400 bilhões por ano para alcançar esse objetivo, um expressivo volume de recursos, porém, segundo essa entidade, pequeno face aos US\$4,5 trilhões que circulam pela indústria dos transportes e os US\$ 700 bilhões de subsídios anuais dados ao setor de petróleo.
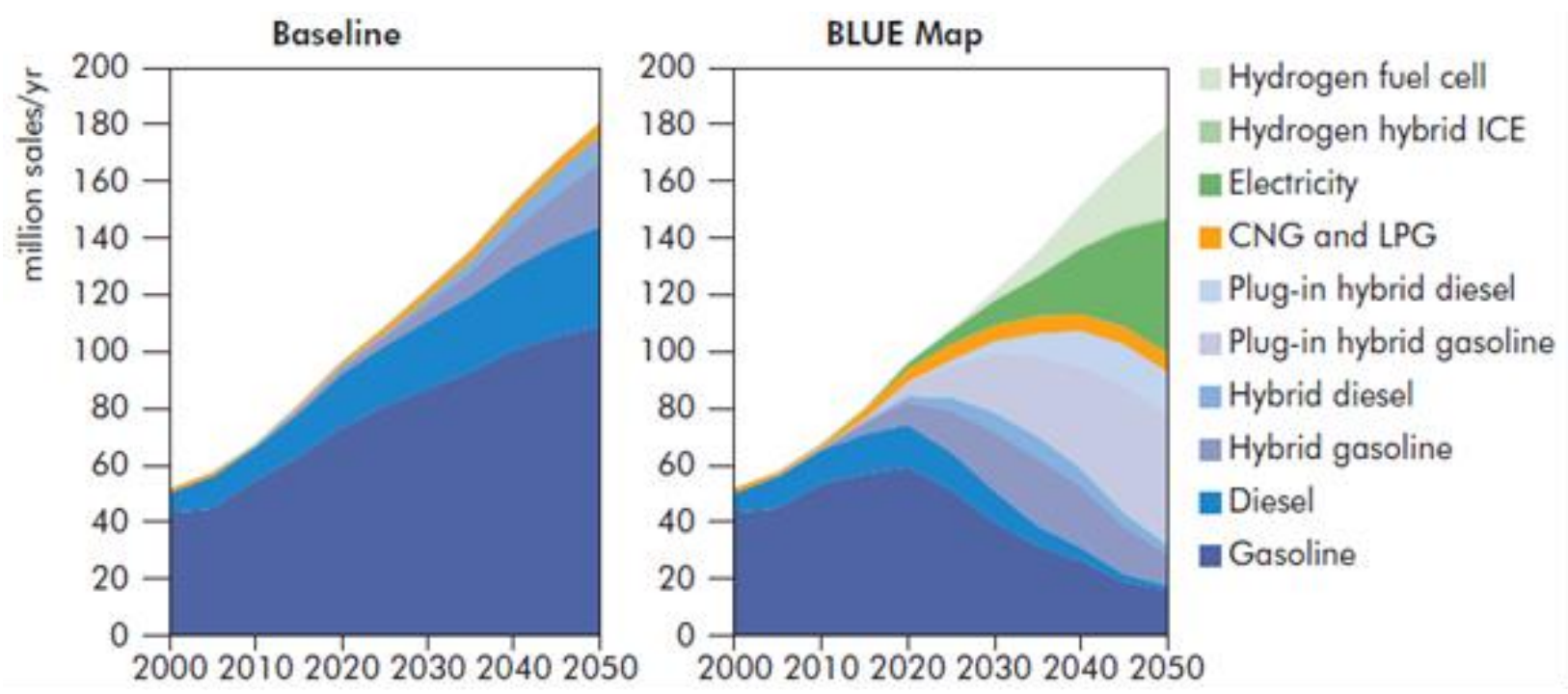

Ilustração 2.24 - Previsão da evolução das vendas de veículos leves de passageiros por tecnologia para dois diferentes cenários, segundo a IEA.

Fonte: Gráfico 7.16, pg. 276, de “Energy Technologies Perspectives - Scenarios \& Strategies to 2050", publicado pela IEA em 2010.

Em curto prazo, a evolução das regulamentações que restringem o consumo ou a emissão de GEE indica as expectativas que os governos dos países ou blocos têm sobre os avanços que o aperfeiçoamento da tecnologia veicular pode proporcionar. A Ilustração 2.25 mostra graficamente a evolução recente da emissão média de $\mathrm{CO}_{2}$ por quilômetro das frotas de veículos leves, os objetivos impostos pela legislação vigente e as metas propostas ou em estudo 
dos mais representativos países e blocos econômicos. As principais metas estão resumidas na Tabela 2.8, onde também são apresentadas as variações médias anuais implícitas nessas metas.

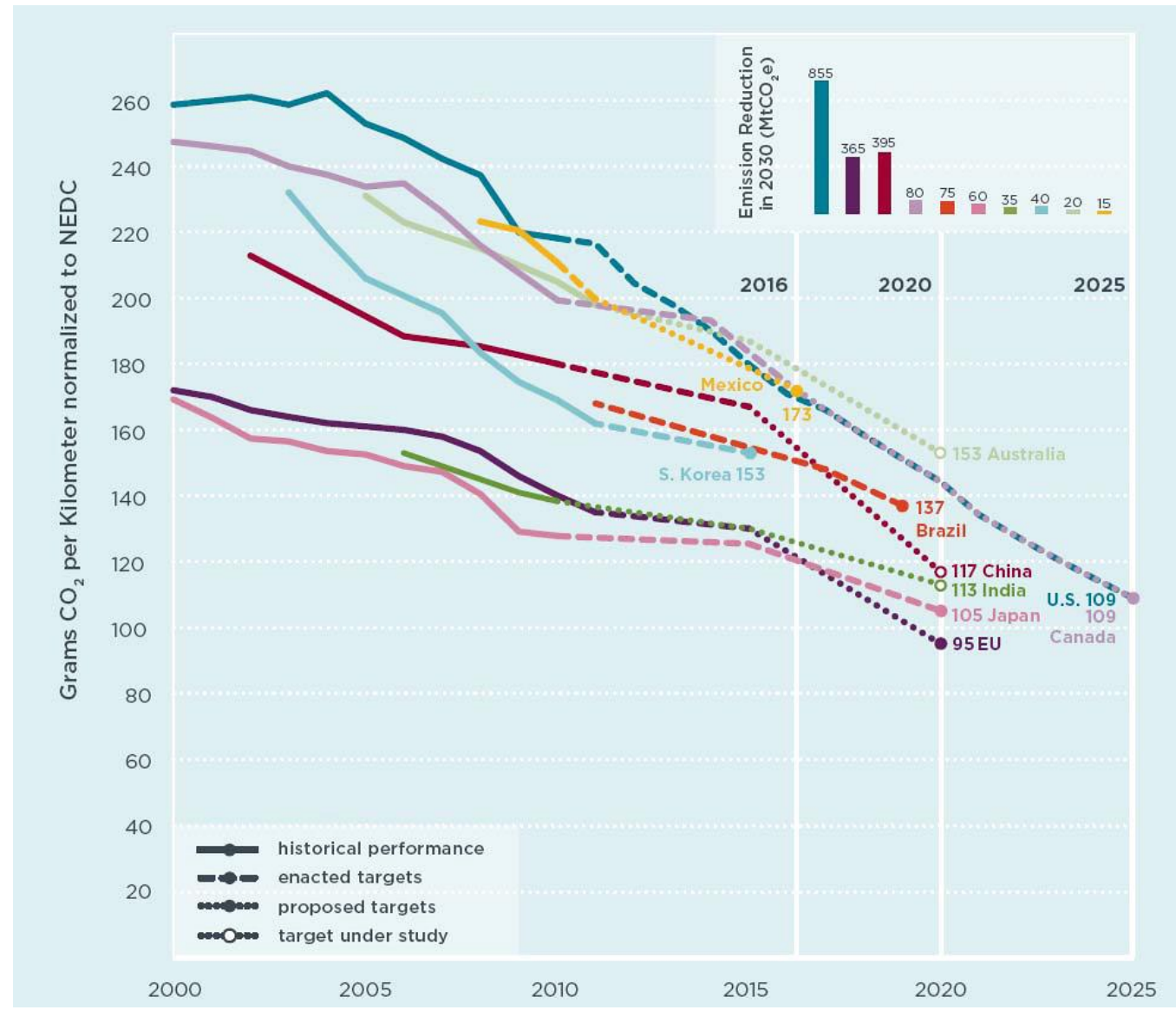

Ilustração 2.25 - Consumo de veículos leves - Histórico da evolução recente, metas impostas pela legislação vigente e metas em discussão.

Fonte: “Global Transportation Energy and Climate Roadmap”, publicado pelo ICCT em 2012.

Tabela 2.8 - Veículos leves - Evolução das metas de emissão de GEE.

\begin{tabular}{ccc|ccc|ccc}
\hline & \multicolumn{2}{c|}{ Linha de base } & \multicolumn{3}{c|}{ Meta em vigor } & \multicolumn{2}{c}{ Meta proposta ou em estudo } \\
\cline { 2 - 9 } Região & ano & $\mathbf{g}_{\mathbf{C O} 2 / \mathbf{k m}}$ & ano & $\mathbf{g}_{\mathbf{C O} 2 / \mathbf{k m}} \begin{array}{c}\text { variação } \\
\text { média } \\
\text { anual }\end{array}$ & ano & $\mathbf{g}_{\mathbf{C O} 2 / \mathbf{k m}}$ & $\begin{array}{c}\text { variação } \\
\text { média } \\
\text { anual }\end{array}$ \\
\hline China & 2008 & 185 & - & - & - & 2015 & 167 & $1,5 \%$ \\
Japão & 2009 & 131 & 2015 & 125 & $3,7 \%$ & 2020 & 105 & $4,2 \%$ \\
$\begin{array}{c}\text { Comunidade } \\
\text { Europeia }\end{array}$ & 2010 & 142 & 2015 & 130 & $2,3 \%$ & 2020 & 95 & $6,1 \%$ \\
$\begin{array}{c}\text { Estados } \\
\text { Unidos }\end{array}$ & 2010 & 219 & 2016 & 172 & $4,6 \%$ & 2025 & 107 & $4,6 \%$ \\
\hline
\end{tabular}

Fonte: "Global Comparison of Light-Duty Vehicle Fuel Economy GHG Emission Standards - Update: August 2011 ”, publicado pelo ICCT em 2011. 
Com relação a esses dados convém fazer-se a seguinte observação. Em alguns casos, os valores prescritos pelas legislações diferem dos aqui apresentados. Isso ocorre porque, como existem diferentes procedimentos de ensaio para avaliação do consumo dos veículos, para ser possível essa comparação, o ICCT desenvolveu e aplicou uma metodologia para estimar a correspondência dos valores obtidos segundo os diferentes protocolos de ensaio. Os valores apresentados nesse gráfico e nessa tabela utilizam como referência o padrão da Comunidade Europeia.

A meta de redução de consumo estabelecida pelo programa brasileiro Inovar-Auto em 2012 é de 12,08\% até 2017 ( 2,31\% aa), sendo concedidos incentivos fiscais adicionais para as empresas que atingirem e manterem até 2020 resultados superiores a 15,46\% ( 2,92\% aa) ou $18,8 \%(\sim 3,51 \%$ aa).

As metas também se diferem quanto ao atributo do veículo utilizado para classificá-los, em geral, a massa ou o porte do veículo. Este último melhor representaria o critério tipicamente utilizado pelos usuários ao selecionar o veículo. Classes baseadas em massa são utilizadas pela Comunidade Europeia, Japão, Coreia do Sul e China. Porém, essa abordagem tende a desestimular a redução da massa do veículo, uma das alternativas utilizadas para aumentar sua eficiência energética. Os EUA, o Canada e o Brasil utilizam classes baseadas na área da projeção horizontal do veículo, uma medida indireta de seu porte, como mostrado na Ilustração 2.26. No entanto, a área projetada não permite distinguir um veículo baixo (ex. veículo esportivo) de um alto (ex. camioneta ${ }^{67}$ ), e caso não seja aplicada alguma segregação adicional, esse critério isoladamente também pode causar distorções.

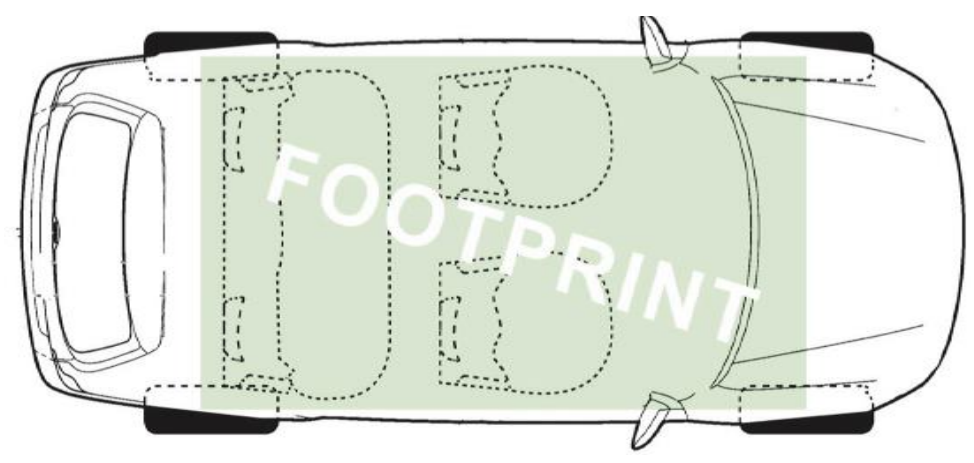

Ilustração 2.26 - Projeção horizontal do veículo utilizada para caracterizar o porte do veículo utilizado nos EUA e Canada.

Fonte: “How Clean Are Europe's Cars?”, publicado pela EFTE em 2011.

\footnotetext{
${ }^{67}$ Popularmente conhecida por perua ou "van".
} 
Além da avaliação da evolução do consumo dos veículos leves em direção às metas, convém também detalhar alguns aspectos de como ela vem se processando. Um estudo recentemente publicado pela Federação Europeia para Transporte e Meio Ambiente (EFTE, sigla em inglês) (2011) relata o que vem ocorrendo na Comunidade Europeia. O primeiro destaque importante são as diferenças entre a primeira meta estabelecida, voluntária, e a atual meta legal. A meta voluntária firmada em 1998 era de 140 g $\mathrm{CO}_{2} / \mathrm{km}$ em 2008, enquanto que a atual meta compulsória é de $130 \mathrm{~g}_{\mathrm{CO} 2} / \mathrm{km}$ em 2015. Antes da regulamentação, de 2000 a 2007, as reduções da emissão média de $\mathrm{CO}_{2}$ por km eram da ordem de 1,2\% ao ano. Após a regulamentação, de 2008 a 2010, as reduções da emissão média de $\mathrm{CO}_{2}$ por $\mathrm{km}$ foram da ordem de 4,0\% ao ano, um significativo avanço em relação aos anos anteriores.

O segundo é que existem diferenças significativas entre os fabricantes. Na Tabela 2.9 são apresentados os resultados das quinze maiores montadoras do mercado europeu em 2010. Observe que nesse ano em particular as variações da emissão média ponderada de $\mathrm{CO}_{2}$ por km entre os fabricantes variaram de $-9,3 \%$ a $0,6 \%$. É preciso reconhecer que esses resultados são afetados pelo posicionamento desses fabricantes no mercado.

Tabela 2.9 - Veículos leves - Emissões médias de $\mathrm{CO}_{2} / \mathrm{km}$ por fabricante observadas na Comunidade Europeia em 2010.

\begin{tabular}{|c|c|c|c|c|c|c|}
\hline \multirow{2}{*}{$\begin{array}{c}\text { Classificação } \\
\text { em } 2010\end{array}$} & \multirow[t]{2}{*}{ Fabricante } & \multirow{2}{*}{$\begin{array}{c}\text { Classificação } \\
\text { em } 2009\end{array}$} & \multirow[t]{2}{*}{$\begin{array}{l}\text { Vendas } \\
\text { em } 2010\end{array}$} & \multicolumn{2}{|c|}{$\begin{array}{l}\mathrm{CO}_{2} / \mathrm{km} \text { médio dos } \\
\text { veículos vendidos }\end{array}$} & \multirow[t]{2}{*}{ Variação } \\
\hline & & & & 2009 & 2010 & \\
\hline 1 & Fiat & 1 & 982.002 & 130 & 126 & $-3,5 \%$ \\
\hline 2 & Toyota & 2 & 584.857 & 131 & 130 & $-1,3 \%$ \\
\hline 3 & PSA & 3 & 1.791.176 & 135 & 131 & $-2,9 \%$ \\
\hline 4 & Renault & 4 & 1.378 .234 & 139 & 136 & $-2,1 \%$ \\
\hline 5 & Ford & 7 & 1.079 .078 & 144 & 137 & $-4,9 \%$ \\
\hline 6 & Suzuki & 6 & 192.121 & 140 & 137 & $-2,6 \%$ \\
\hline 7 & Hyundai & 5 & 580.802 & 141 & 138 & $-1,7 \%$ \\
\hline 8 & $\mathrm{GM}$ & 9 & 1.148 .845 & 148 & 139 & $-6,0 \%$ \\
\hline 9 & Volkswagen & 12 & 2.813 .854 & 152 & 143 & $-6,2 \%$ \\
\hline 10 & Honda & 8 & 174.559 & 146 & 147 & $0,6 \%$ \\
\hline 11 & Nissan & 13 & 390.376 & 153 & 147 & $-4,1 \%$ \\
\hline 12 & BMW & 11 & 718.422 & 151 & 148 & $-2,2 \%$ \\
\hline 13 & Mazda & 10 & 171.114 & 149 & 149 & $0,3 \%$ \\
\hline 14 & Volvo & - & 206.787 & 173 & 157 & $-9,3 \%$ \\
\hline \multirow[t]{2}{*}{15} & Daimler & 14 & 648.912 & 166 & 161 & $-3,0 \%$ \\
\hline & & \multicolumn{2}{|c|}{ Valores médios } & 145,7 & 140,3 & $-3,7 \%$ \\
\hline
\end{tabular}

Fonte: Tabela elaborada pelo autor com base em dados do artigo "How Clean Are Europe's Cars?", publicado pela EFTE em 2011. 
A Ilustração 2.27 mostra não somente o posicionamento e o peso desses fabricantes nesse contexto, mas também o quão distante eles estão da meta estabelecida. De qualquer forma, considerando que as metas da Comunidade Europeia estão entre as mais ambiciosas e que se trata de fabricantes globais, esses dados são bastante representativos dos avanços possíveis de serem alcançados nessa área.

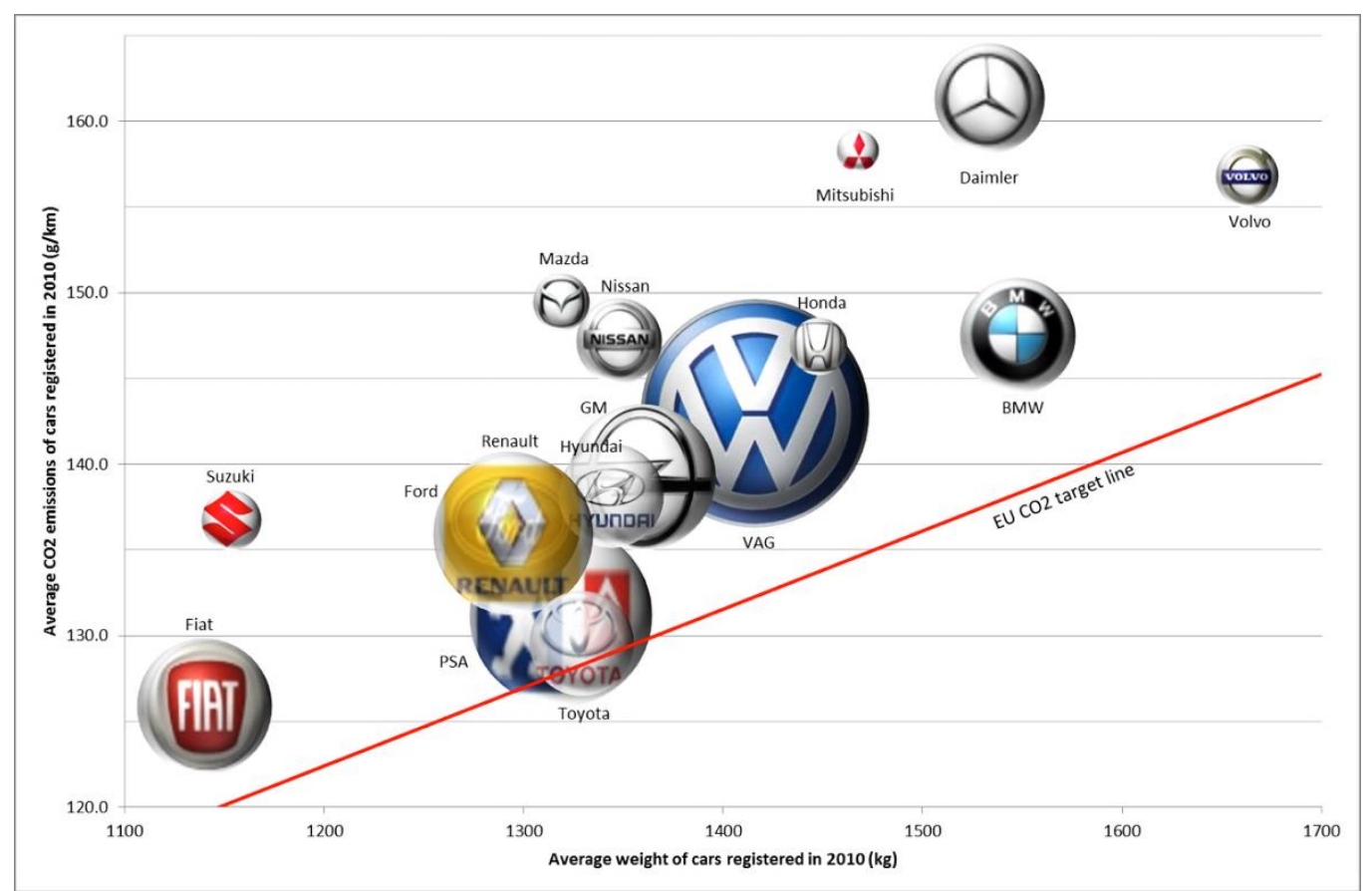

Ilustração 2.27 - Veículos leves - Posicionamento no mercado e emissões médias de $\mathrm{CO}_{2} / \mathrm{km}$ por fabricante observadas na Comunidade Europeia em 2010.

Fonte: “How Clean Are Europe's Cars?”, publicado pela EFTE em 2011.

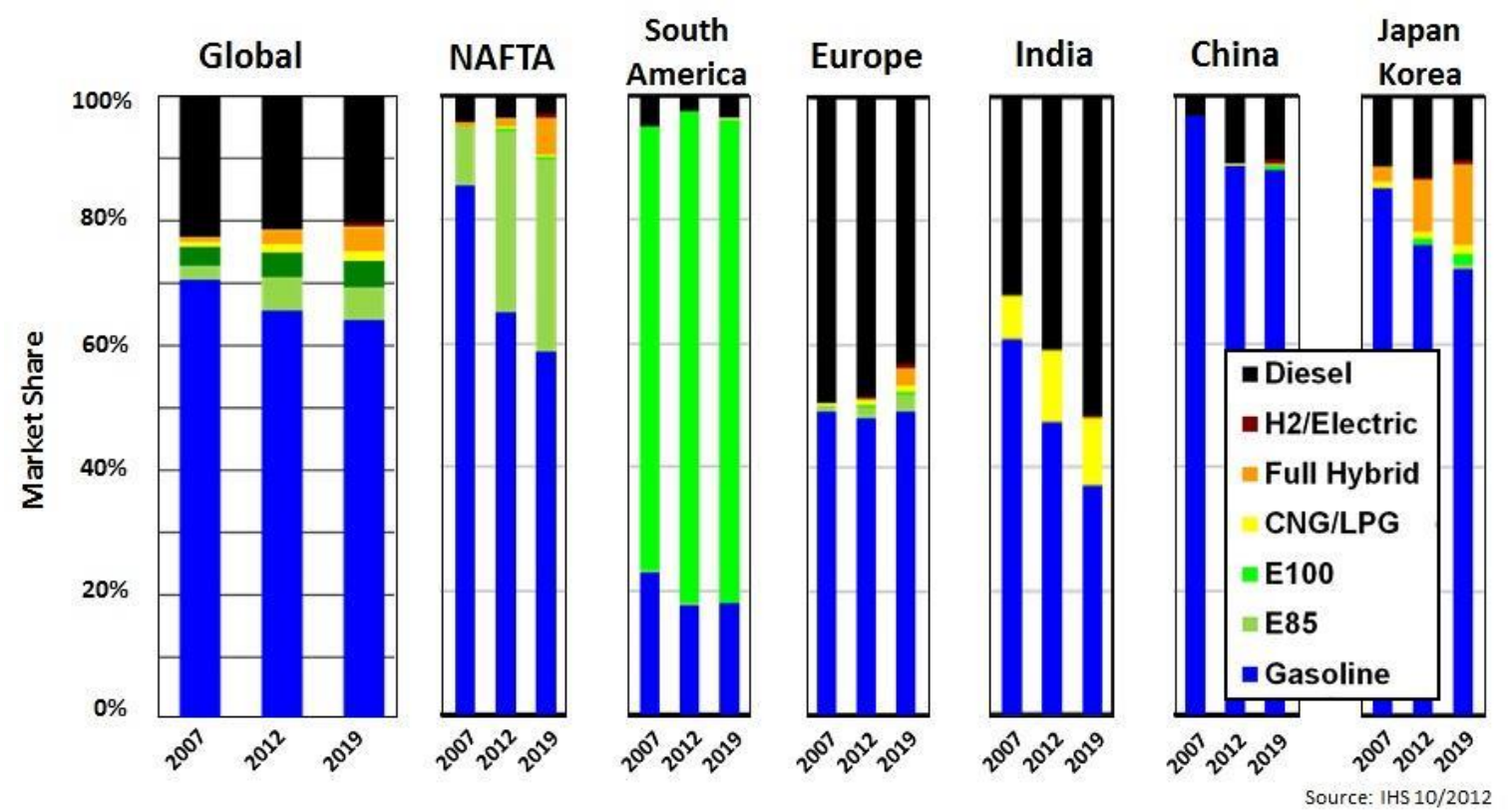

Ilustração 2.28 - Histórico e projeção da participação das tecnologias nas regiões.

Fonte: Slide 9 da apresentação de FAIDL, G. “Market \& technology trends passenger car power train”, 2013. 
Outra importante constatação desse trabalho é que a previsão de aumento de preço dos veículos realizada em 2005, baseada em questionários enviados aos fabricantes que tendem a responder de forma conservadora, de $€ 1.200$ (base 2002) para atingir-se a meta de $140 \mathrm{~g}_{\mathrm{CO} 2} / \mathrm{km}$ não se confirmou. Ao contrário, os preços dos veículos nesse período caíram em média cerca de 13\%, possivelmente devido a fatores tais como amadurecimento tecnológico, escala de produção, concorrência e situação econômica.

Quanto às tecnologias empregadas em veículos leves, em curto prazo, a IHS prevê a evolução mostrada na Ilustração 2.28 anterior. De 2012 a 2019, as mudanças mais expressivas são: o aumento da participação de veículos a diesel na Índia e dos híbridos nos países desenvolvidos. Ao contrário destes, o prognóstico para o mercado sul-americano que, como a participação do E100 (veículos a álcool) indica, é predominantemente o mercado brasileiro, apesar da meta de redução de consumo aqui existente, é que novas tecnologias terão uma participação somente marginal.

Fazer estimativas para veículos pesados é uma situação bem mais complexa, em função da dificuldade de se estabelecer procedimentos de avaliação objetivos para toda a diversidade de soluções tecnológicas, tipos de veículos ${ }^{68}$ e condições de uso, mostrada na Ilustração 2.23 anterior, e de se fixar metas que considerem, além de todos esses aspectos, também o peso dos diversos segmentos desses veículos no consumo e emissões de cada nação.

Consequentemente, o desenvolvimento de regulamentações pertinentes à matéria é recente e os critérios nelas aplicados não são uniformes. O cronograma dos programas de redução de consumo de veículos pesados em implantação, e provável dos programas em discussão, é apresentado na Tabela 2.10 .

Como mostrado na Tabela 2.11, as características técnicas básicas dos principais programas divergem significativamente, o que dificulta uma concentração de recursos e esforços dos fabricantes visando esse desenvolvimento.

Apesar de ainda não se conhecer a eficácia desses programas, as características e as metas dos programas vigentes estão resumidas a seguir. As Tabelas 2.12 e 2.13 apresentam os programas do Japão e dos Estados Unidos, respectivamente.

\footnotetext{
${ }^{68}$ Muitas vezes configurados especificamente para as condições dos clientes.
} 
Tabela 2.10 - Cronograma dos programas de redução de consumo para veículos pesados.

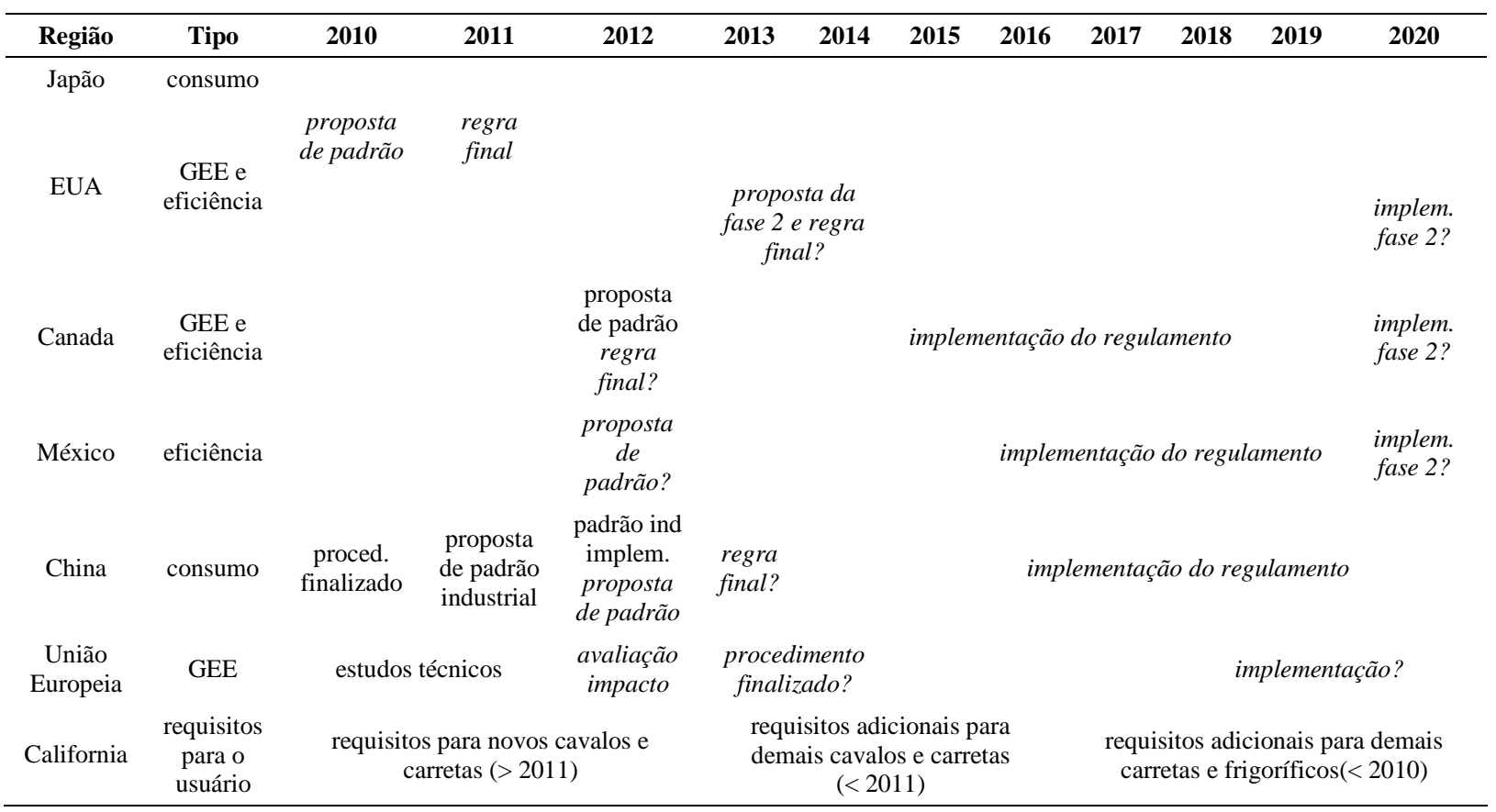

Nota: os itens destacados em itálico são estimativas do ICCT sobre o que deve ocorrer.

Fonte: Slide 4 da apresentação do ICCT "Heavy-Duty Vehicle Fuel Efficiency Regulatory Developments around the World", $2012^{69}$

Tabela 2.11 - Principais características dos programas para veículos pesados.

\begin{tabular}{|c|c|c|c|c|c|}
\hline Região & Categorias & Proced. certificação & & Unidade & \\
\hline Japão & $\begin{array}{c}\text { outros caminhões } \\
\text { cavalos mecânicos } \\
\text { ônibus rodoviários } \\
\text { outros ônibus }\end{array}$ & $\begin{array}{c}\text { modelo de simulação } \\
+ \\
\text { ensaio motor em bancada }\end{array}$ & & $\begin{array}{c}\text { eficiência } \\
(\mathrm{km} / \mathrm{l})\end{array}$ & \\
\hline $\begin{array}{l}\text { América } \\
\text { do Norte }\end{array}$ & $\begin{array}{l}\text { cavalos mecânicos } \\
\text { veículos pesados de serviços } \\
\text { caminhonetes e camionetas } \\
\text { motores (cavalos e serviços) }\end{array}$ & $\begin{array}{c}\text { de veículos } \rightarrow \\
\text { modelo de simulação } \\
\text { de motores } \rightarrow \\
\text { ensaio motor em bancada }\end{array}$ & $\begin{array}{c}\text { cavalos, } \\
\text { serviços } \\
\text { gal/1000 } \\
\text { ton.mi } \\
\text { g/ton.mi }\end{array}$ & $\begin{array}{l}\text { "pickups" } \\
\text { pesadas } \\
\text { gal/100mi }\end{array}$ & $\begin{array}{c}\text { motores } \\
\text { gal/100 } \\
\text { bhp.h } \\
\text { g/kW.h }\end{array}$ \\
\hline China & $\begin{array}{l}\text { cavalos, caminhões de lixo, } \\
\text { outros caminhões, ônibus } \\
\text { urbanos, outros ônibus }\end{array}$ & $\begin{array}{l}\text { ensaio do veículo base em } \\
\text { dinamômetro de chassi } \\
\text { dos veículos derivados por } \\
\text { modelo de simulação }\end{array}$ & & $\begin{array}{l}\text { consumo } \\
(\mathrm{l} / 100 \mathrm{~km})\end{array}$ & \\
\hline $\begin{array}{c}\text { União } \\
\text { Europeia }\end{array}$ & $\begin{array}{l}\text { classes de caminhões e ônibus } \\
\text { baseados no PBT e } \\
\text { configurações de chassi e eixos }\end{array}$ & modelo de simulação & & $\begin{array}{c}G E E \\
(\mathrm{~g} / \text { ton. } \mathrm{km})\end{array}$ & \\
\hline
\end{tabular}

Nota: os itens destacados em itálico são estimativas do ICCT sobre o que deve ocorrer

Fonte: Slide 10 da apresentação do ICCT “Heavy-Duty Vehicle Fuel Efficiency Regulatory Developments Around the World", 2012.

${ }^{69}$ Disponível em <http://www.theicct.org/sites/default/files/Bandivadekar_Bangalore_july2012.pdf>, acessado em 26/07/2013. 
Tabela 2.12 - Metas do programa para veículos pesados vigente no Japão.

\begin{tabular}{|c|c|c|c|c|c|}
\hline \multirow{2}{*}{\multicolumn{2}{|c|}{ Tipo de veículo }} & \multicolumn{2}{|c|}{ Eficiência [km/l] } & \multirow{3}{*}{$\begin{array}{c}\begin{array}{c}\text { Aumento da } \\
\text { eficiência }\end{array} \\
9,7 \%\end{array}$} & \multirow{3}{*}{$\begin{array}{c}\begin{array}{c}\text { Redução } \\
\text { média anual } \\
\text { do consumo }\end{array} \\
0,63 \%\end{array}$} \\
\hline & & \multirow{2}{*}{$\begin{array}{c}\text { Ref. (2002) } \\
2,67\end{array}$} & \multirow{2}{*}{$\begin{array}{c}\text { Meta para } \\
\mathbf{2 0 1 5} \\
2,93\end{array}$} & & \\
\hline \multirow{2}{*}{ caminhões } & cavalo mec. & & & & \\
\hline & outros & 6,56 & 7,36 & $12,2 \%$ & $0,84 \%$ \\
\hline \multirow{2}{*}{ ônibus } & urbanos & 4,51 & 5,01 & $11,1 \%$ & $0,77 \%$ \\
\hline & outros & 6,19 & 6,98 & $12,8 \%$ & $0,87 \%$ \\
\hline
\end{tabular}

Notas: (1) Eficiência é calculada com base nos resultados do ensaio do motor em bancada e simulação que considera adicionalmente as características do câmbio e cargas resistivas.

(2) O cálculo para cumprimento da meta de 2015 assumirá a mesma composição relativa da frota.

Fonte: Tabela elaborada pelo autor com base em dados do artigo de Drew Kodjak "Global evolution of heavy-duty vehicle fuel economy and GHG regulations”, publicado na Future Science em 2011.

Tabela 2.13 - Metas do programa para veículos pesados vigente nos Estados Unidos.

\begin{tabular}{|c|c|c|c|c|c|c|}
\hline & \multirow{2}{*}{\multicolumn{2}{|c|}{ Tipo de veículo }} & \multicolumn{3}{|c|}{ Redução em relação a 2010} & \multirow{2}{*}{$\begin{array}{c}\text { Redução } \\
\text { média } \\
\text { anual }\end{array}$} \\
\hline & & & Motor & Veículo & $\begin{array}{l}\text { Veículo } \\
\text { e motor }\end{array}$ & \\
\hline \multirow{7}{*}{ cavalo mecânico $^{(1)}$} & \multirow{4}{*}{$\begin{array}{l}\text { cabine curta } \\
\text { ("day cab") }\end{array}$} & classe 7 teto baixo/médio & $6 \%$ & $2 \%$ & $8 \%$ & $1,1 \%$ \\
\hline & & classe 7 teto alto & $6 \%$ & $5 \%$ & $11 \%$ & $1,6 \%$ \\
\hline & & classe 8 teto baixo/médio & $6 \%$ & $1 \%$ & $7 \%$ & $1,0 \%$ \\
\hline & & classe 8 teto alto & $6 \%$ & $4 \%$ & $10 \%$ & $1,4 \%$ \\
\hline & \multirow{3}{*}{$\begin{array}{l}\text { cabine longa } \\
\text { ("sleepers") }\end{array}$} & classe 8 teto baixo & $6 \%$ & $9 \%$ & $15 \%$ & $2,1 \%$ \\
\hline & & classe 8 teto médio & $6 \%$ & $9 \%$ & $15 \%$ & $2,1 \%$ \\
\hline & & classe 8 teto alto & $6 \%$ & $14 \%$ & $20 \%$ & $2,6 \%$ \\
\hline \multirow{3}{*}{$\begin{array}{l}\text { "vocacionais" (1) } \\
\text { (ex. ônibus urbanos, } \\
\text { caminhões de lixo, de } \\
\text { entrega, de serviço e } \\
\text { basculantes) }\end{array}$} & leve & classe $2 b-5$ & $9 \%$ & $1 \%$ & $10 \%$ & $1,4 \%$ \\
\hline & médio & classe $6-7$ & $9 \%$ & $2 \%$ & $10 \%$ & $1,4 \%$ \\
\hline & pesado & classe 8 & $5 \%$ & $2 \%$ & $7 \%$ & $1,0 \%$ \\
\hline \multirow{2}{*}{$\begin{array}{l}\text { caminhonetes e } \\
\text { camionetas }^{\left({ }^{3}\right)}\end{array}$} & gasolina & & & & $12 \%$ & $1,5 \%$ \\
\hline & diesel & & & & $17 \%$ & $2,1 \%$ \\
\hline
\end{tabular}

Notas: (1) Metas de redução válidas para 2017.

(2) Metas de redução válidas para 2018.

(3) A emissão em $\mathrm{g}_{\mathrm{CO} 2} /$ ton.milha é calculada pelo modelo de simulação GEM que considera configuração aerodinâmica, redução do peso, resistência ao rolamento, e a presença de limitador de velocidade, de dispositivos de redução do tempo do motor em marcha-lenta e da tecnologia híbrida. O regulamento não se aplica a classe 6 onde, segundo a NAS, essa tecnologia tem grande potencial.

(4) O ônus de comprovar o atendimento das metas é do fabricante do chassi ou veículo básico.

Fonte: Tabela elaborada pelo autor com base em dados do artigo de Drew Kodjak "Global evolution of heavy-duty vehicle fuel economy and GHG regulations”, publicado na Future Science em 2011.

O programa da Califórnia, ao invés de estabelecer metas numéricas, obriga que exclusivamente uma parcela dos caminhões “estradeiros”, aquela responsável pela maior parcela do consumo 
de combustível, tenham a certificação "SmartWay"70, tornando este programa voluntário do governo federal estadunidense em obrigatório. Essa certificação se baseia na comprovação do uso de dispositivos aerodinâmicos e pneus de baixa resistência ao rolamento no cavalo e na carreta, válida tanto para veículos novos com para os veículos em uso. Observar que essa medida relativamente simples, cuja redução de consumo esperada é da ordem de 5\% ou mais, na prática, extrapola as fronteiras desse estado.

As expectativas de redução média anual de consumo neste item revistas serão utilizadas para prognosticar o impacto da evolução da tecnologia no consumo veicular no Brasil. Convém lembrar que este segmento é tradicionalmente muito sensível ao consumo de combustível.

\subsubsection{O setor de transportes rodoviário}

A evolução do setor de transporte rodoviário depende de vários outros tópicos além da tecnologia veicular e dos combustíveis anteriormente revistos. Ela envolve aspectos tão diversos como o contexto geográfico, a infraestrutura física e o arcabouço legal existentes e a competitividade de modais concorrentes. Ela é também condicionada por questões fiscais (ex. arrecadação de tributos), sociais (ex. emprego e geração de renda), políticas (ex. incentivo a setores econômicos e mitigação de diferenças regionais), ambientais (ex. bacias aéreas saturadas, preservação ambiental e mudança climática) e mesmo culturais (ex. status manifestado por meio de um veículo). Mas essa evolução está principalmente correlacionada a fatores econômicos, fato que será verificado adiante. Antes de apontar outras frentes possíveis para intervir nessa evolução, convém primeiro contextualizar resumidamente sua dimensão, suas características básicas e suas perspectivas globais.

\subsubsection{Caracterização do setor}

Como se pode derivar da Ilustração 2.29, em 2010 o setor de transportes foi responsável por cerca de $27 \%$ da demanda total de energia, dos quais $96,5 \%$ provenientes de combustíveis fósseis, $2,5 \%$ de combustíveis renováveis e $1 \%$ de eletricidade, gerada a partir de diversas fontes. O consumo global do setor de transportes segregado por fonte e modo em 2010 é apresentado na Ilustração 2.30, onde se verifica que o transporte rodoviário foi responsável por cerca de $77 \%$ do consumo total, em grande parte proveniente de derivados de petróleo.

\footnotetext{
${ }^{70}$ Para maiores informações ver < http://epa.gov/smartway/>, acessado em 27 jul. 2013.
} 


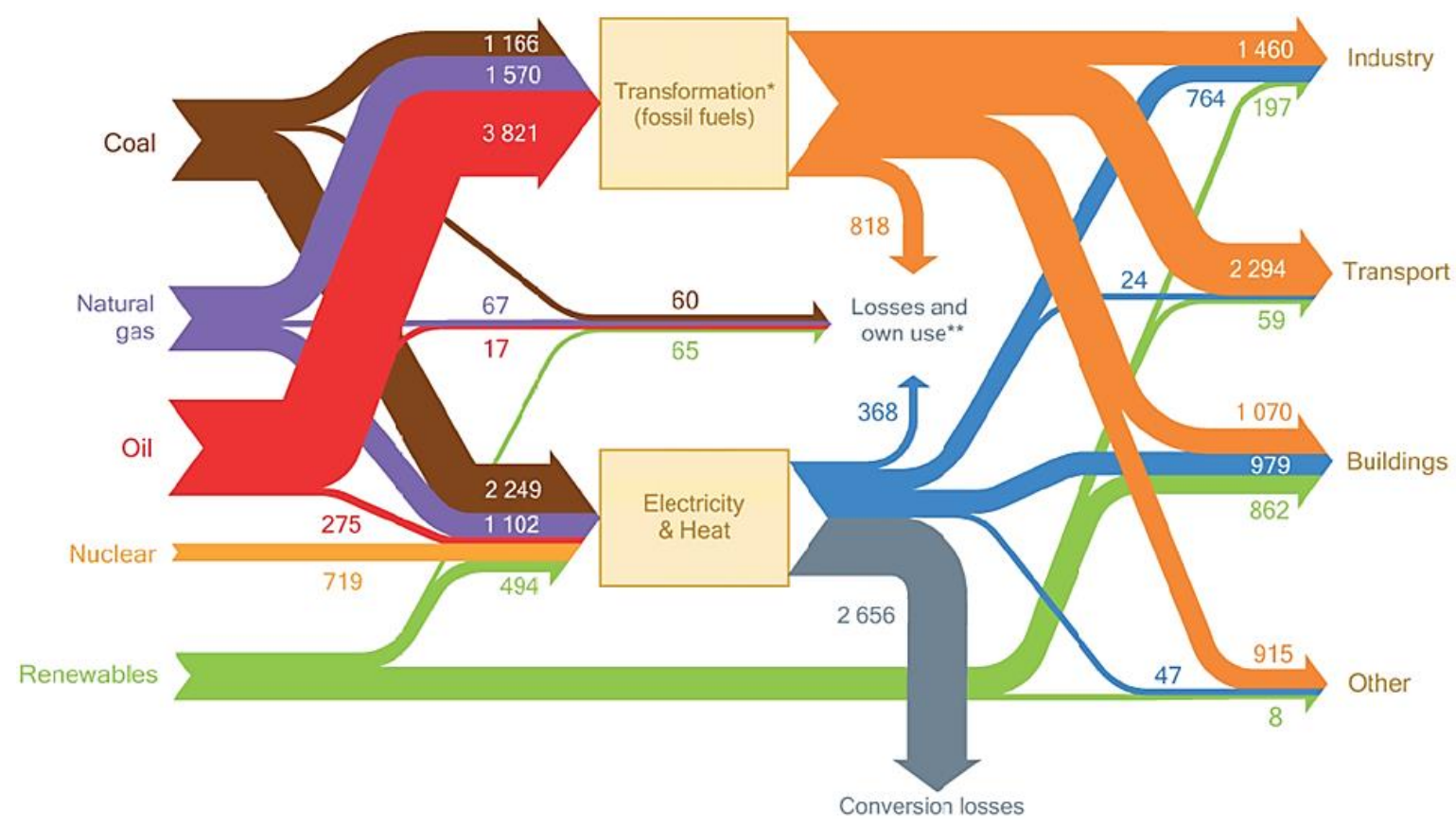

Ilustração 2.29 - Matriz energética mundial em 2010 (valores em Mtep).

Fonte: Ilustração 2.8, pg. 62, do “World Energy Outlook 2012”, publicado pela IEA em 2012.

2010 Transport energy consumption by source

2010 Transport energy consumption by mode
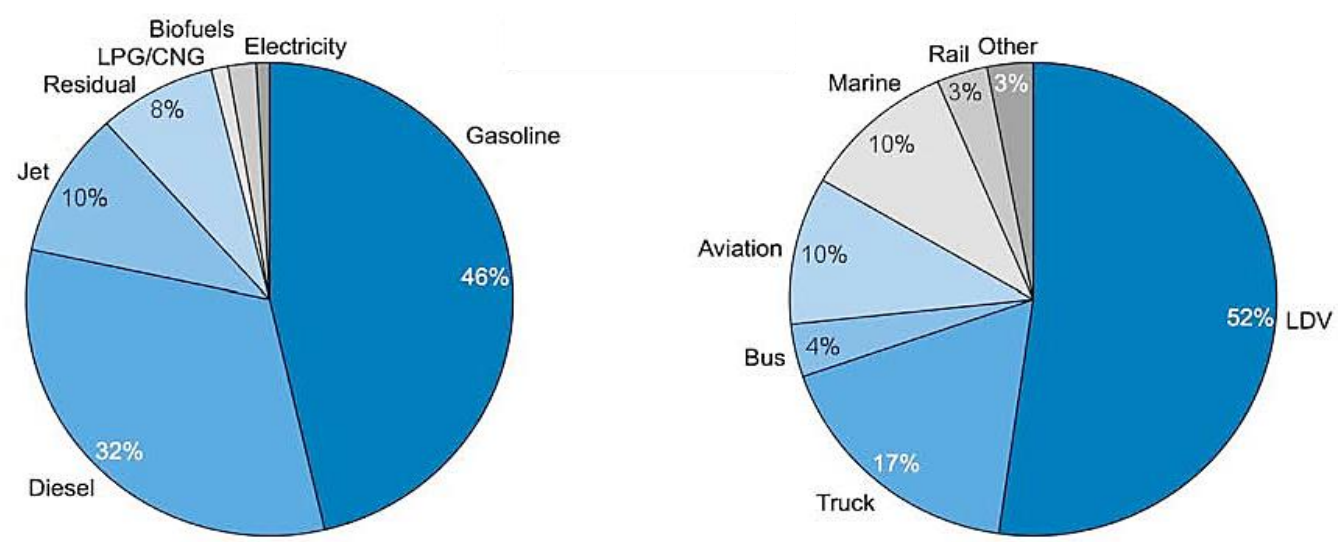

Source: IEA/SMP, IMO, IATA, Carbon Neutral Skies team analysis, Repowering Transport team analysis

Nota: "Outro" refere-se a motociclos.

Ilustração 2.30 - Consumo energético global em transportes por fonte e modo em 2010.

Fonte: Ilustração 4, pg. 11, do “Repowering Transport”, publicado pela WEF em 2011.

Mantidas as políticas atuais, a taxa de crescimento projetada do consumo global do setor, conforme apresentado na Ilustração 2.31, é de 1,7\% ao ano, o que implica em um consumo em 2030 cerca de $40 \%$ superior ao de 2010 e, consequentemente, em um crescimento da emissão de $\mathrm{CO}_{2}$ do setor da mesma ordem. 


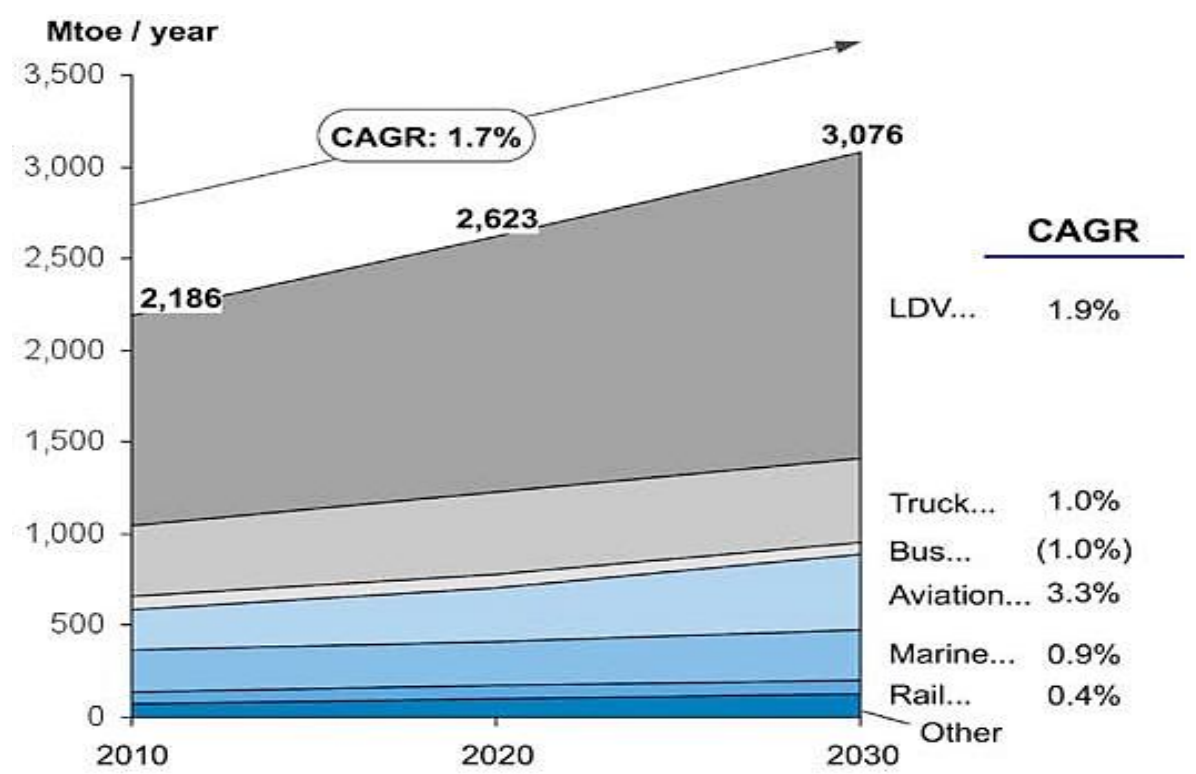

Nota: "CAGR" é a sigla em inglês para taxa de crescimento anual composta, "Outro" refere-se a motociclos.

\section{Ilustração 2.31 - Crescimento do consumo dos transportes por modo projetado até 2030 no cenário "políticas atuais".}

Fonte: Ilustração 5, pg. 12, do "Repowering Transport", publicado pela WEF em 2011.

Contrapondo-se a esse cenário, a IEA indica como mais provável o cenário "novas políticas"71, que prognostica um crescimento mais moderado, porém ainda de cerca de $1 \%$ ao ano, como indicado na Ilustração 2.32. Esse gráfico mostra também o consumo de petróleo recente e estimado para 2035 e a participação dos transportes, inclusive rodoviário, nesse consumo.

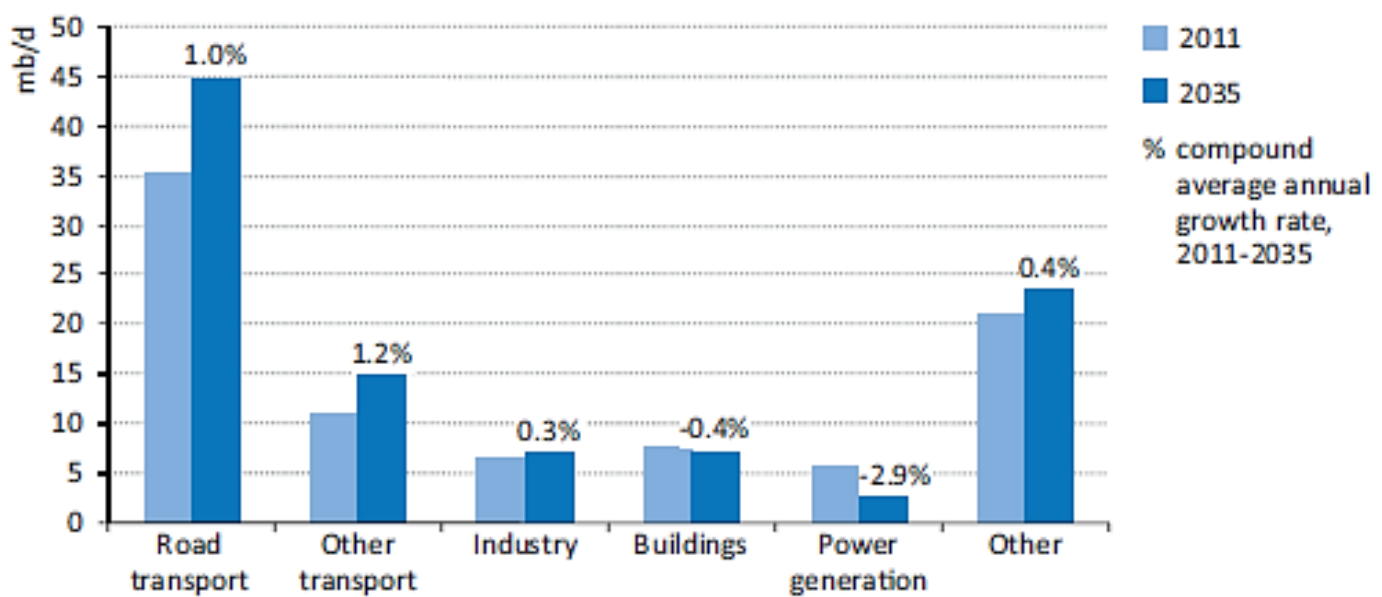

Nota: "Outro" refere-se a usos não energéticos do petróleo, inclusive matéria prima para a indústria.

\section{Ilustração 2.32 - Demanda global de petróleo por setor no cenário "novas políticas".}

Fonte: Ilustração 3.3, pg. 88, do “World Energy Outlook 2012”, publicado pela IEA em 2012.

\footnotetext{
${ }^{71}$ Os cenários utilizados pela IEA foram descritos no item 3.2.1.1.
} 
Esse fato decorre da projeção de crescimento das frotas mostradas nas Ilustrações 2.33 e 2.34, onde se destacam o forte crescimento das frotas da China e da Índia, tanto de automóveis como de caminhões. O crescimento da frota brasileira de automóveis projetada pela IEA é menos expressiva, mas ainda assim significativa.

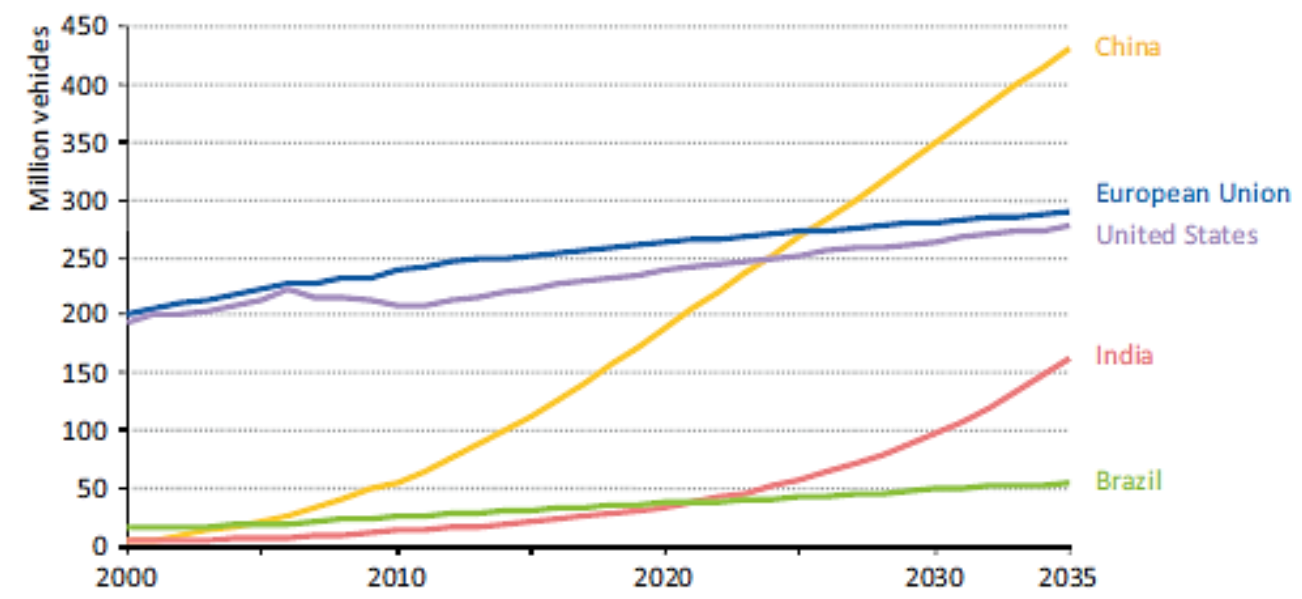

Ilustração 2.33 - Histórico e projeção da evolução das frotas de automóveis por região no cenário "novas políticas".

Fonte: Ilustração 3.6, pg. 91, do “World Energy Outlook 2012”, publicado pela IEA em 2012.

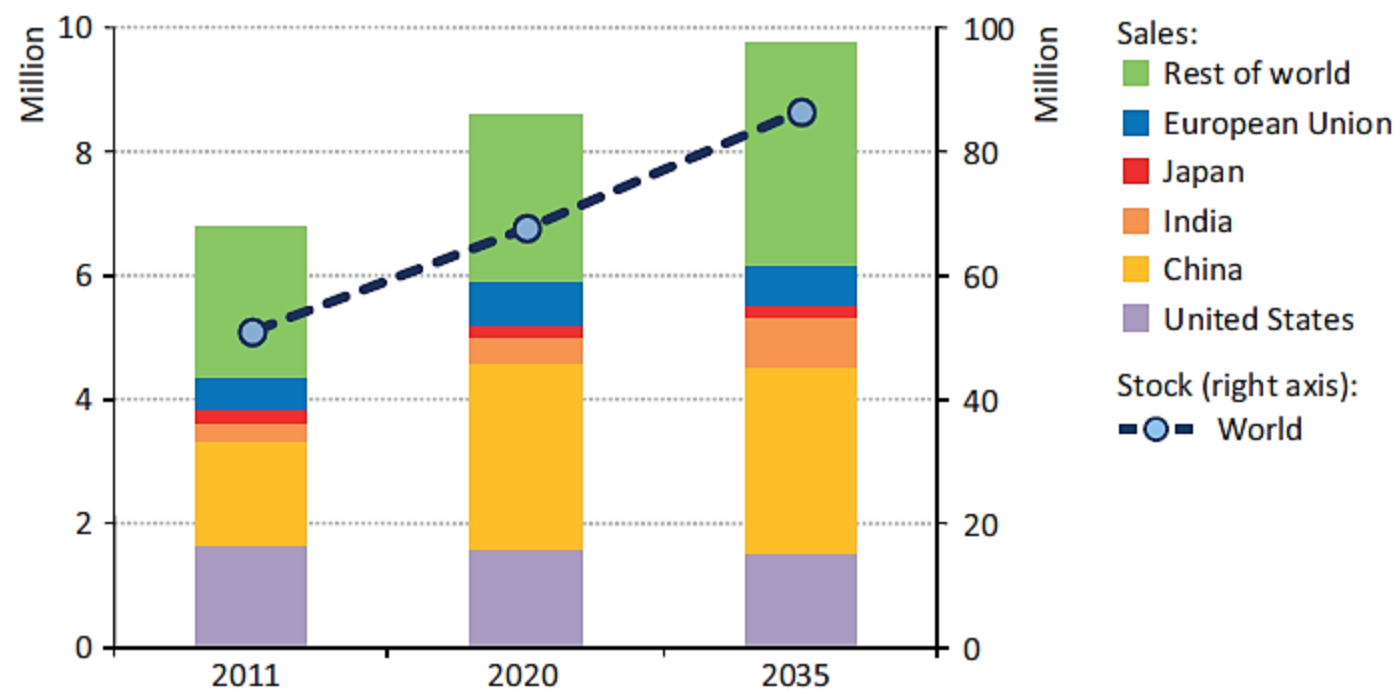

Ilustração 2.34 - Histórico e projeção da evolução das vendas e das frotas de caminhões por região no cenário "novas políticas".

Fonte: Ilustração 3.8, pg. 93, do “World Energy Outlook 2012”, publicado pela IEA em 2012.

O impacto no consumo e preço do petróleo para três cenários utilizados pela IEA, inclusive o "novas políticas", pode ser visto na Ilustração 2.35. Verifica-se pelo gráfico abaixo, que no cenário "novas políticas", supostamente o mais provável, esta agência prevê um crescimento do consumo energético até 2035 de aproximadamente 15\%, que em conjunto com outras fontes de 
GEE ainda aponta para um aumento de temperatura média global em longo prazo de $3,6{ }^{\circ} \mathrm{C}$. Neste cenário, prediz-se que o preço do petróleo se manterá razoavelmente estável.

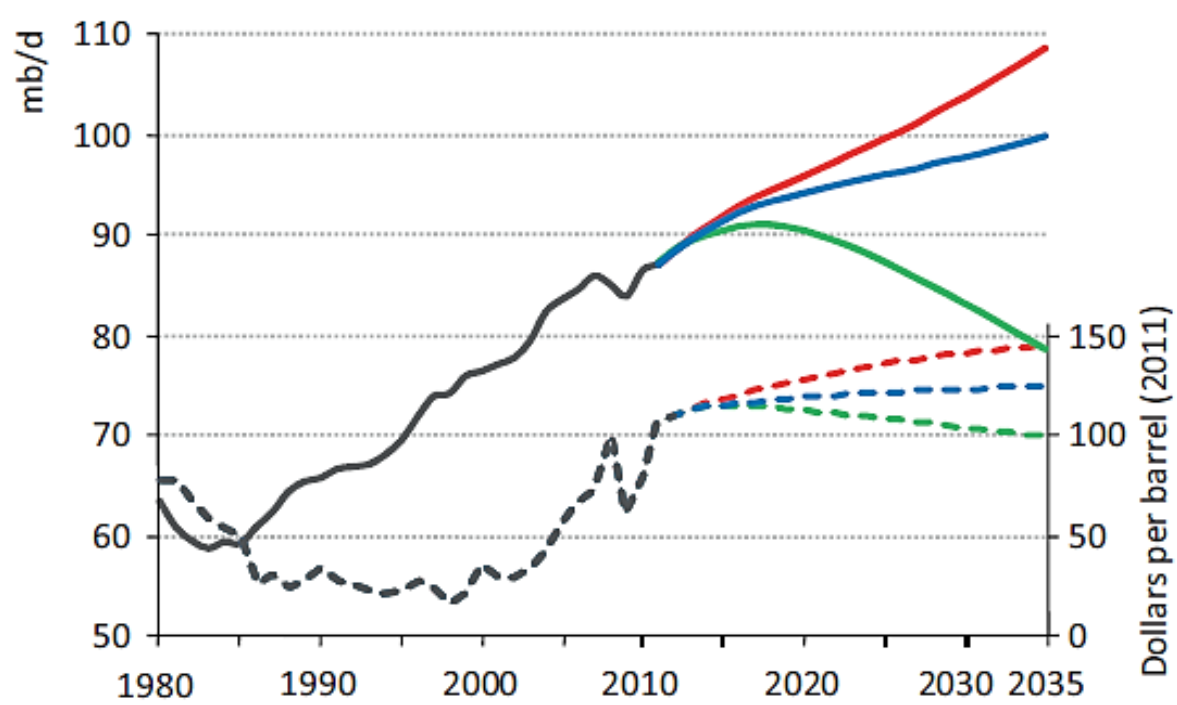

Oil demand:

Current Policies Scenario

- New Policies Scenario

- 450 Scenario

Oil price (right axis):

- $=$ Current Policies Scenario

= $=$ New Policies Scenario

=ே= 450 Scenario

\section{Ilustração 2.35 - Consumo global e preço do petróleo projetados para diferentes cenários.}

Fonte: Ilustração 3.1, pg. 82, do “World Energy Outlook 2012”, publicado pela IEA em 2012.

No Brasil, em 2011, o setor de transportes foi responsável por cerca de $30 \%$ do consumo energético total, acima da média mundial, e por $61,4 \%$ do consumo nacional de petróleo e gás natural (EPE 2012). Além disso, como se vê nas Ilustrações 2.36 e 2.37, essa participação vem crescendo. No entanto, confrontando com gráficos anteriores, verifica-se que o consumo brasileiro em transportes representa somente $2,4 \%$ do consumo mundial correspondente.

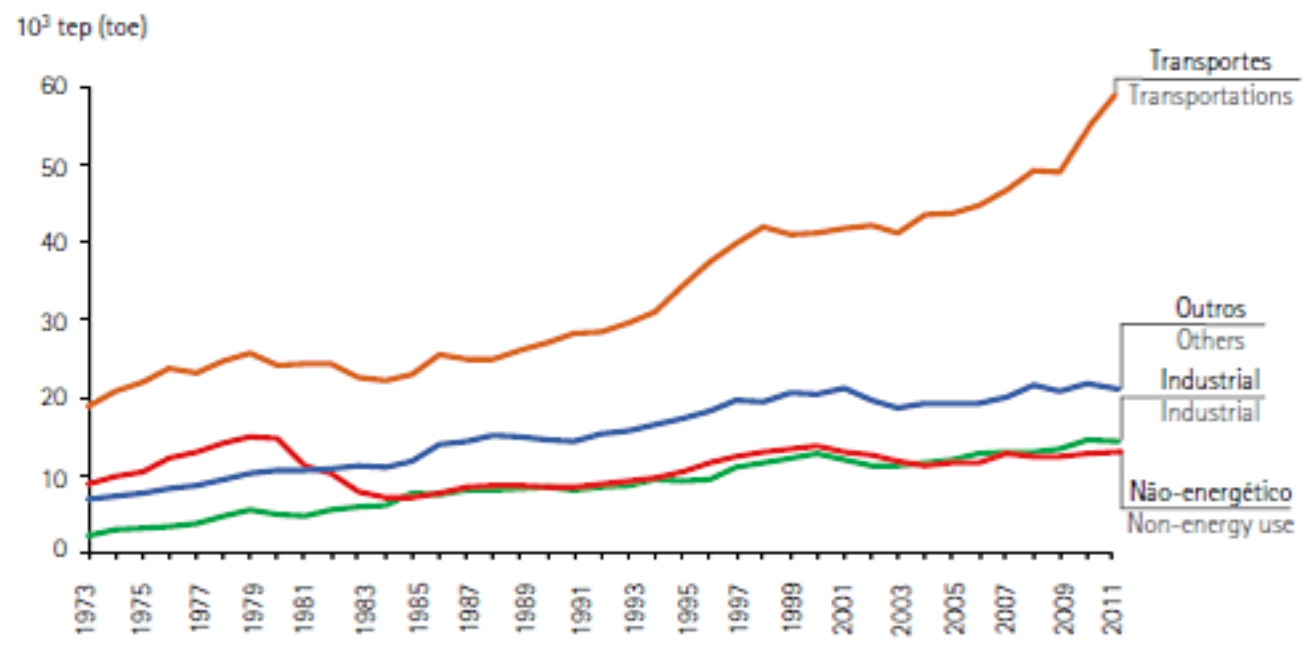

Ilustração 2.36 - Consumo anual de derivados de petróleo e de gás natural por uso.

Fonte: Gráfico 2.6, pg. 53, do "Balanço Energético Nacional 2012", publicado pela EPE nesse ano. 


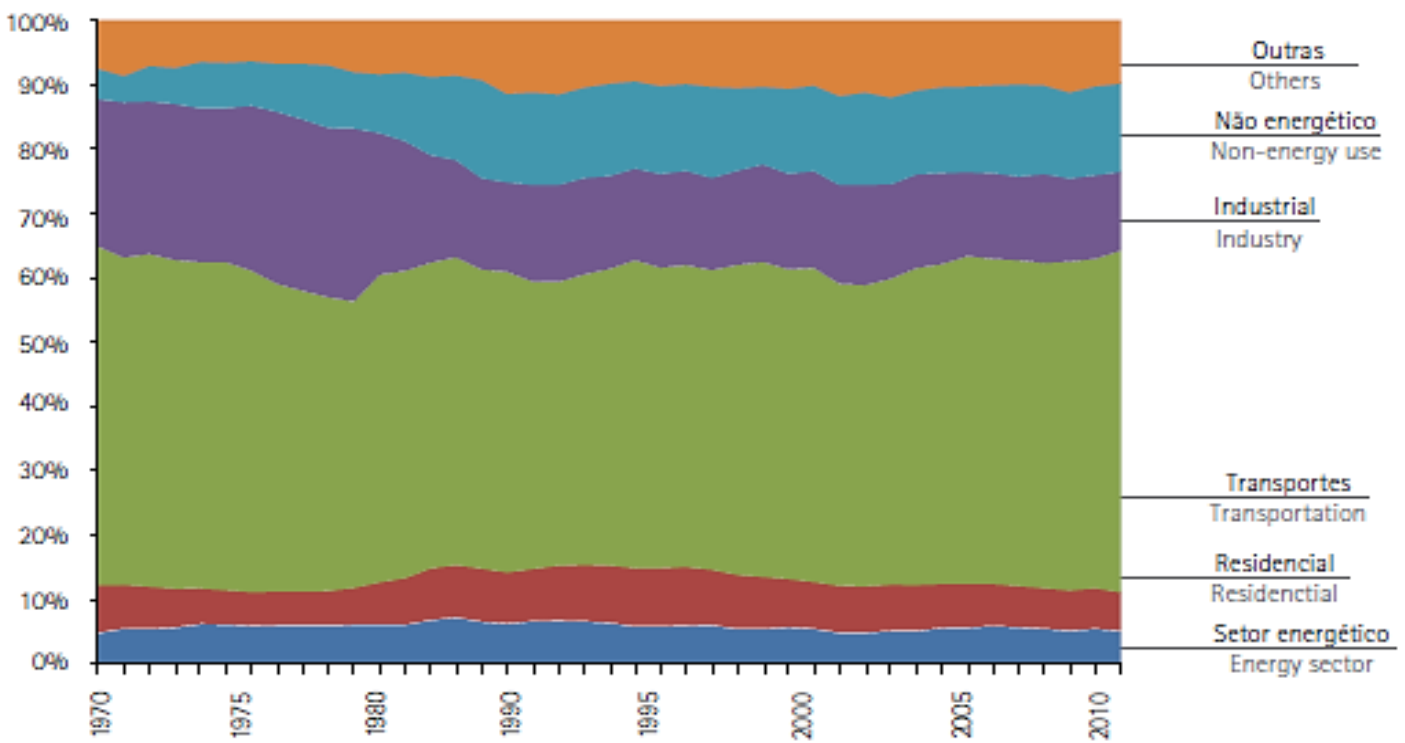

Ilustração 2.37 - Composição setorial do consumo de derivados de petróleo.

Fonte: Gráfico 1.9, pg. 32, do "Balanço Energético Nacional 2012", publicado pela EPE nesse ano.

As participações segregadas por fonte e modo no consumo energético do setor de transportes nacional em 2010 são apresentadas na Ilustração 2.38. Comparando com a média mundial, mostrada na Ilustração 2.30, destacam-se: no gráfico da distribuição por fonte, além da já reconhecida participação do etanol substituindo a gasolina, o fato que no Brasil as participações dos combustíveis rodoviários e, em particular, do óleo diesel são significativamente maiores; e no gráfico da distribuição por modo, fica também evidente uma maior participação do transporte rodoviário de carga em detrimento dos outros modais.
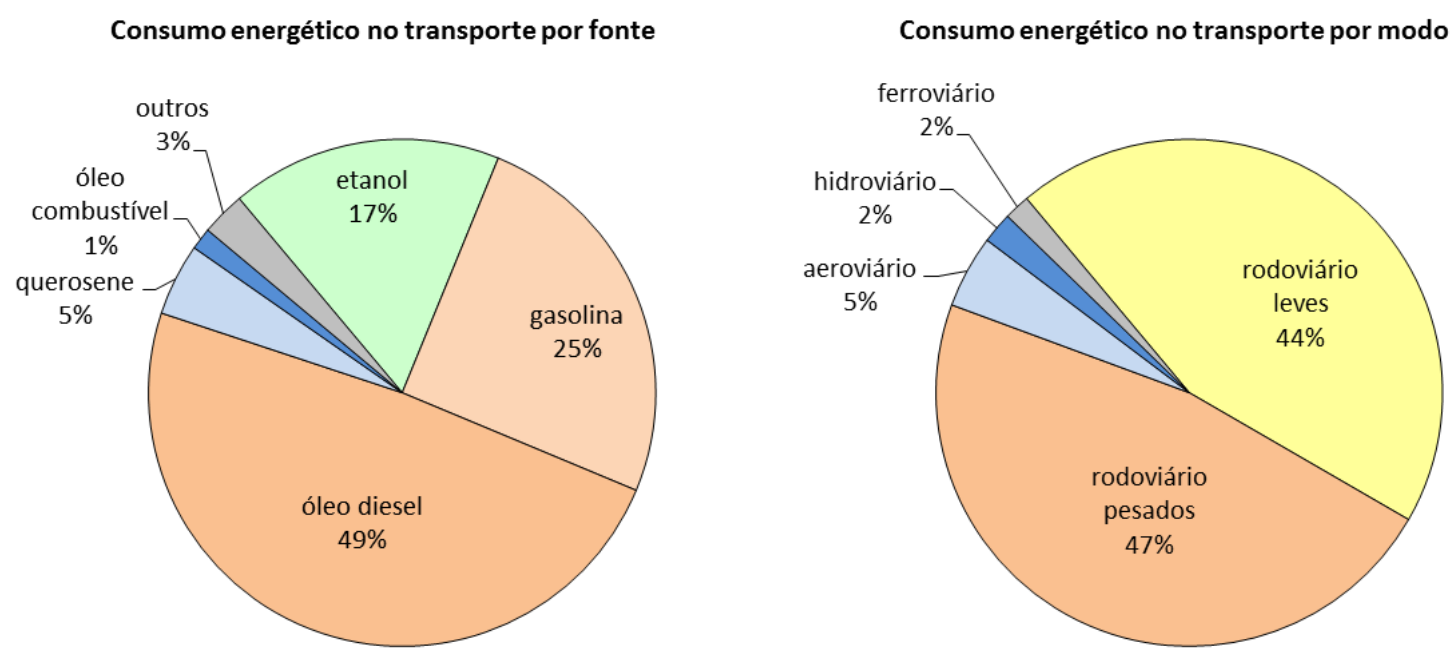

Nota: "Outros" refere-se a GNV e eletricidade.

Ilustração 2.38 - Consumo energético nacional em transportes por fonte e modo em 2010.

Fonte: Elaborado pelo autor com base em dados do "Balanço Energético Nacional 2012". 
No item 2.2.1.3 anterior, no subitem sobre o etanol foi apresentada a evolução do consumo e do preço dos combustíveis rodoviários no Brasil, onde, com base nas Ilustrações de 2.8 a 2.10, foram apontados alguns aspectos desse histórico. Sobressaem-se as variações sazonais, a influência do preço relativo etanol-gasolina vinculada à tecnologia empregada, e o posicionamento do óleo diesel em relação aos combustíveis Otto (gasolina, etanol e GNV).

$\mathrm{Na}$ Tabela 2.14 são apresentados alguns prognósticos que constam do Plano Nacional de Energia 2030 (PNE 2030) (BRASIL 2007) sobre a evolução do consumo nacional de combustíveis e de alguns importantes aspectos a eles relacionados.

Tabela 2.14 - Prognósticos do Plano Nacional de Energia 2030.

\begin{tabular}{|c|c|c|c|c|c|c|}
\hline \multicolumn{2}{|c|}{ Item } & \multirow{2}{*}{$\begin{array}{c}\mathbf{2 0 1 0} \\
20.445\end{array}$} & \multirow{2}{*}{$\frac{\mathbf{2 0 1 5}}{25.379}$} & \multirow{2}{*}{$\begin{array}{c}\mathbf{2 0 2 0} \\
26.246\end{array}$} & \multirow{2}{*}{$\begin{array}{c}\mathbf{2 0 2 5} \\
33.861\end{array}$} & \multirow{2}{*}{$\frac{\mathbf{2 0 3 0}}{42.657}$} \\
\hline & gasolina & & & & & \\
\hline evolução da demanda de & etanol & 17.400 & 25.500 & 32.400 & 40.700 & 52.500 \\
\hline$\left(10^{3} \mathrm{~m}^{3}\right)$ & óleo diesel rodoviário & 41.878 & 49.698 & 56.837 & 67.405 & 80.146 \\
\hline & biodiesel & 2.095 & 2.988 & 3.987 & 6.714 & 9.644 \\
\hline \multicolumn{2}{|c|}{ proporção de B100 no biodiesel } & $5 \%$ & $6 \%$ & $7 \%$ & $10 \%$ & $12 \%$ \\
\hline \multicolumn{2}{|c|}{ volume de gasolina importada $\left(10^{3} \mathrm{~m}^{3}\right)$} & 190 & -3.221 & -5.668 & -1.024 & 4.103 \\
\hline \multicolumn{2}{|c|}{ volume de etanol exportado $\left(10^{3} \mathrm{~m}^{3}\right)$} & 6.730 & 11.180 & 18.630 & 16.640 & 9.630 \\
\hline \multicolumn{2}{|c|}{$\%$ de etanol celulósico do total de etanol produzido } & $0,5 \%$ & $4,6 \%$ & $8,9 \%$ & $10,2 \%$ & $11,5 \%$ \\
\hline
\end{tabular}

Fonte: Tabela elaborada pelo autor com base em dados do PNE 2030.

Quanto à composição da frota brasileira, infelizmente os critérios empregados para segregá-la e os números divulgados pelas diferentes fontes oficiais muitas vezes divergem significativamente, a ponto mesmo de órgãos de governo, como o Ministério de Meio Ambiente (MMA) e a CETESB, preferirem realizar seus inventários a partir de estimativas realizadas em função do número de veículos novos licenciados. Como muitas vezes não é dada baixa dos veículos sucateados e muitos veículos circulam sem estarem devidamente licenciados, a frota real situa-se entre o número de veículos cadastrados no RENAVAM, divulgado pelo DENATRAN, e o número de veículos licenciados, divulgados pelos DETRANs. Esses modelos de simulação mencionados acima serão detalhados adiante.

Antecipando alguns resultados derivados do estudo realizado baseado em modelo próprio, é apresentado nas Ilustrações 2.39 e 2.40, o histórico da evolução da frota brasileira segmentada pelas classes e, no caso dos veículos leves, pelos combustíveis. Nesses gráficos evidenciam-se: 
o acelerado crescimento da frota de motociclos, principalmente após 1997, e das demais frotas de veículos leves e caminhões a partir de 2002; a quase extinção da frota a álcool e o rápido desenvolvimento da frota "flex"; o crescimento da participação de caminhões semipesados e pesados em detrimento da participação dos caminhões médios.
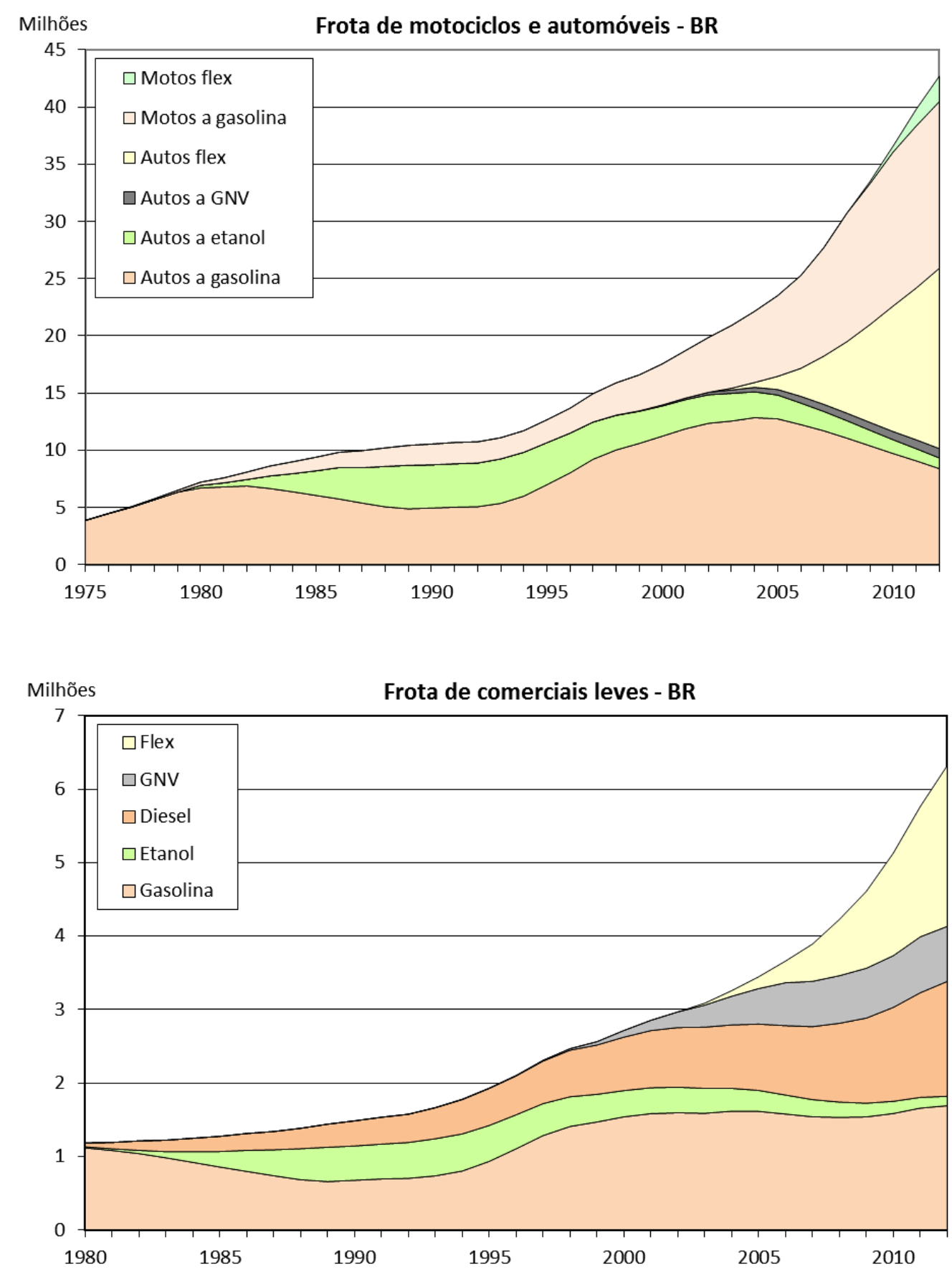

Ilustração 2.39 - Evolução da frota de veículos leves.

Fonte: Elaborado pelo autor com base no modelo de simulação por ele desenvolvido. 

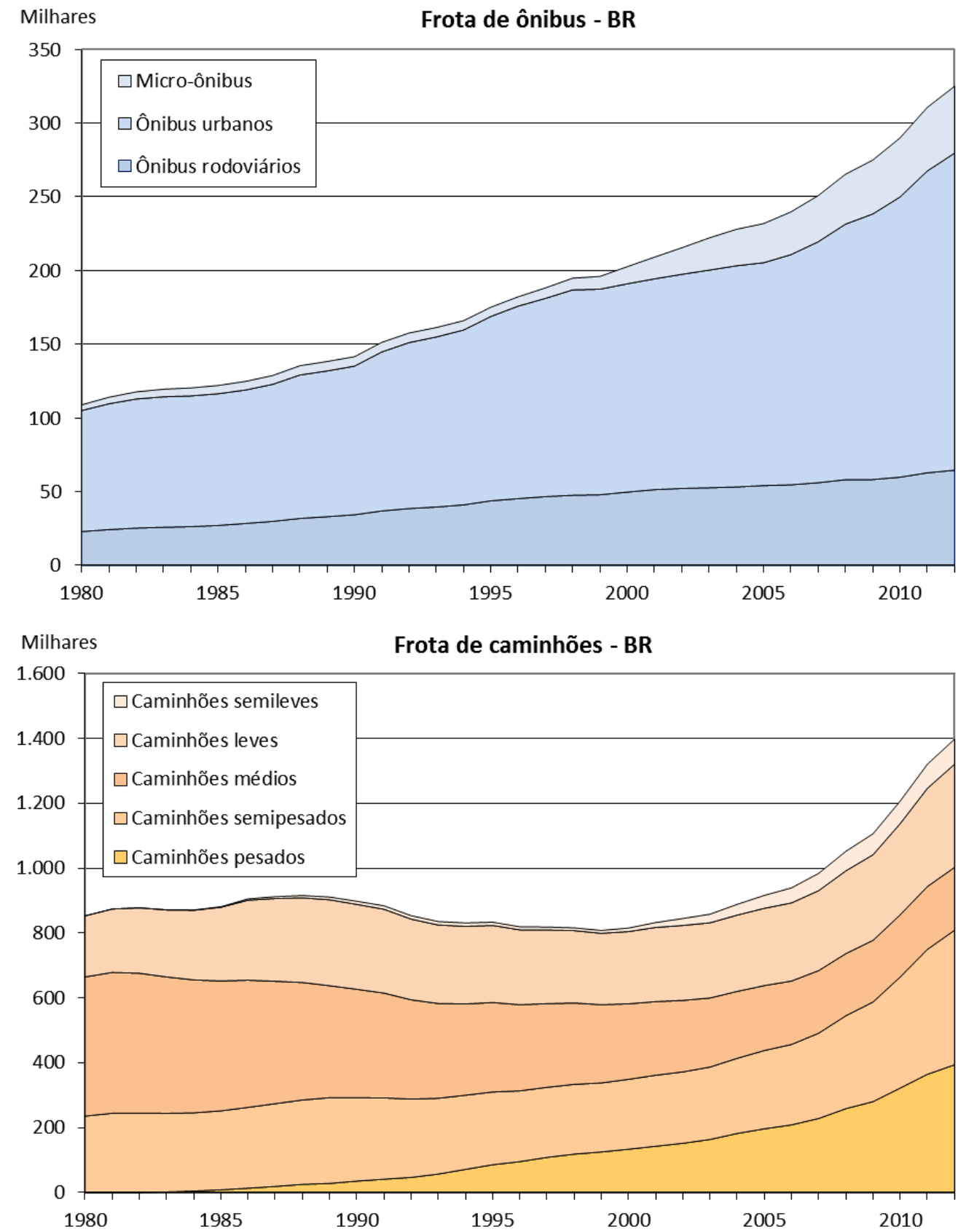

Ilustração 2.40 - Evolução da frota de veículos pesados.

Fonte: Elaborado pelo autor com base no modelo de simulação por ele desenvolvido.

O consumo de combustíveis associado a essas frotas será discutido adiante.

\subsubsection{Outras formas de evoluir o sistema de transporte rodoviário}

Além do aprimoramento da tecnologia veicular, a redução do consumo e das emissões do transporte rodoviário pode advir de uma série de outras medidas, que vão desde mudar a atitude dos motoristas até grandes investimentos em infraestrutura. Ressalve-se que questões de natureza tão diversas como essas muitas vezes são, na prática, correlacionadas. 
Entre as mudanças comportamentais desejáveis têm-se: adoção pelos motoristas de condutas mais adequadas; redução da expectativa por veículos maiores ou de maior desempenho; aumento da ocupação dos veículos; redução da quilometragem rodada por meio de deslocamentos não motorizados (a pé ou bicicleta) ou pelo uso de transporte público. Além de campanhas públicas, essas mudanças podem ser induzidas por alterações na regulamentação e implantação de, por exemplo, ciclovias, faixas exclusivas para veículos com maior ocupação ("HOV", sigla em inglês) ${ }^{72}$ e faixas ou corredores exclusivos para ônibus.

No que tange aos frotistas, operar mais eficientemente implica não somente em utilizar melhores equipamentos, mas também em aprimorar seus sistemas de monitoramento, informação e gestão. Isso envolve, por exemplo: o treinamento dos motoristas; a seleção de rotas e horários menos congestionados e de veículos mais adequados; renovação da frota; e visando obter maiores fatores de carregamento ${ }^{73} \mathrm{e}$, no caso de cargas, melhores fretes, o aperfeiçoamento dos sistemas de informação e implantação de centros de distribuição ("hubs"). Como visto no item 2.2.2.2, isso pode ser suprido em parte por sistemas de orientação ao motorista em tempo real. Uma indicação do potencial dessas ações foi dada nas Ilustrações 2.22 e 2.23, sob os títulos de aperfeiçoamento da logística e gerenciamento, respectivamente. Ressalve-se, no entanto, que esses números estimados para países desenvolvidos, podem ser muito diferentes em países menos organizados e com menor capacidade de investimento.

Entretanto, a máxima eficácia e menor impacto ambiental dos sistemas de transporte só podem ser alcançados por meio da abordagem sistêmica da questão, o que em muitas situações extrapola os limites de ação das empresas do setor. Sob o ponto de vista macro, cabe aos governos desenvolver a infraestrutura, e organizar, regulamentar e controlar os fluxos de passageiros e de cargas, inclusive entre modais que competem entre si, de forma a assegurar tanto a mobilidade e a preservação do meio ambiente, como a competitividade e, consequentemente, o desenvolvimento de suas regiões. Esse fato é reconhecido pelo Governo Federal em seu Plano Nacional de Logística e Transportes (PNLT) ${ }^{74}$, e em planos equivalentes dos governos estaduais. Tanto por sua abrangência, com interfaces em diversos segmentos da sociedade, como por sua extensão em termos de prazo e recursos financeiros requeridos, esses

\footnotetext{
72 Visando esse objetivo, são relativamente comuns na América do Norte faixas exclusivas para veículos com maior ocupação. Vide <http://en.wikipedia.org/wiki/High-occupancy_vehicle_lane>, acessado em 05/08/2013.

${ }^{73}$ Seja ela em passageiro-quilômetro ou tonelada-quilômetro.

${ }^{74}$ Vide <http://www.transportes.gov.br/conteudo/36391>, acessado em 05/08/2013.
} 
planos são, em geral, bastante complexos, não somente para a definição de seus objetivos, mas principalmente para viabilizar sua execução. Este trabalho não se propõe a avaliar esses planos, mas pode utilizar destes suas expectativas quanto à migração do transporte de carga do modal rodoviário para outros modais, sem, no entanto, se propor a avaliar o impacto que isso causará nesses outros modais. As Ilustrações 2.41 e 2.42 mostram as metas de migração entre modais, respectivamente, do PNLT e o Plano Diretor de Desenvolvimento de Transportes (PDDT) do Estado de São Paulo (BRAGA \& CASTILLO 2006).
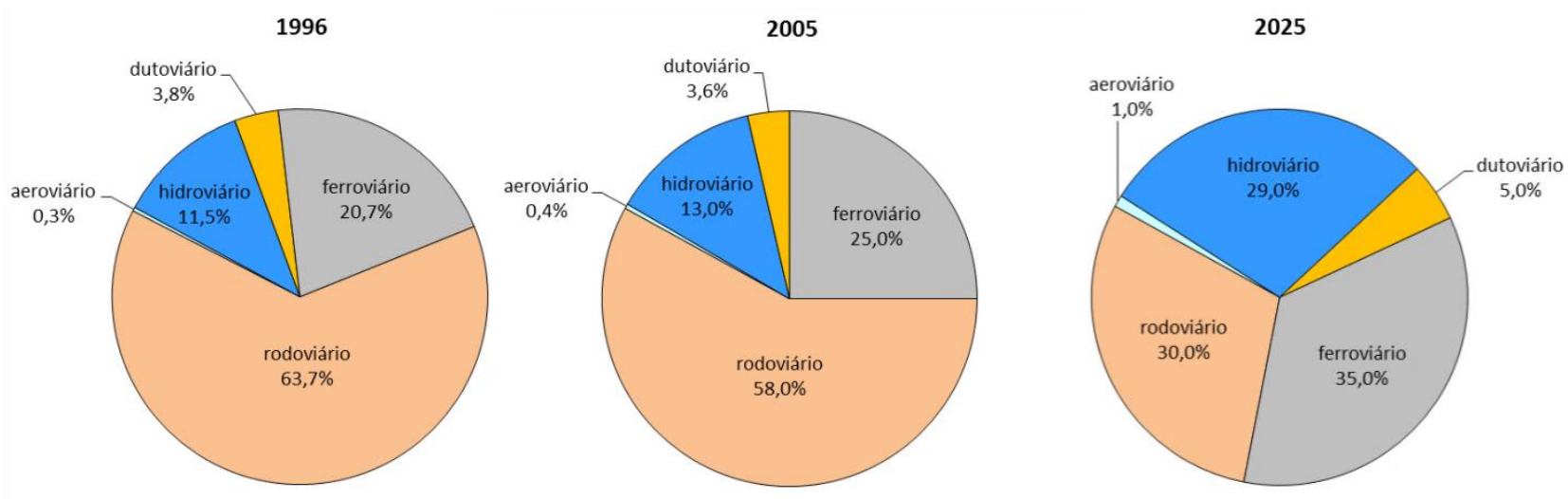

Ilustração 2.41 - Metas de migração modal do Plano Nacional de Logística e Transportes.

Fonte: Elaborado pelo autor com base em dados do PNLT.

2000

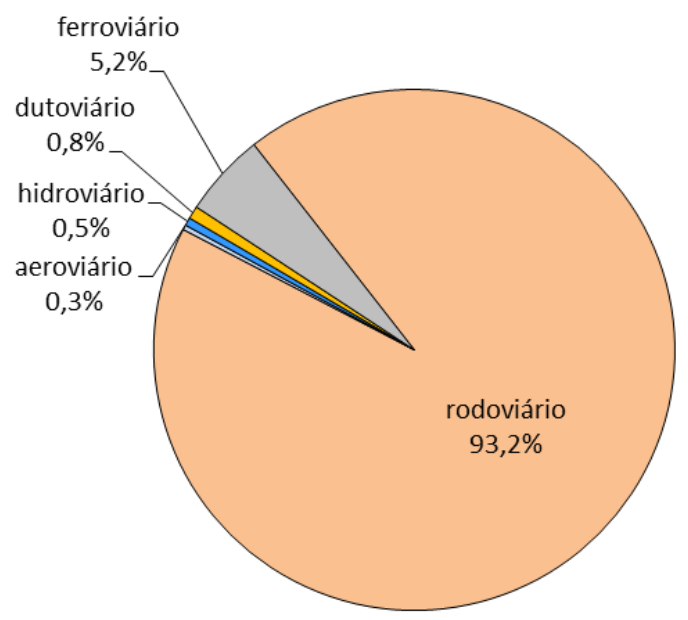

2020

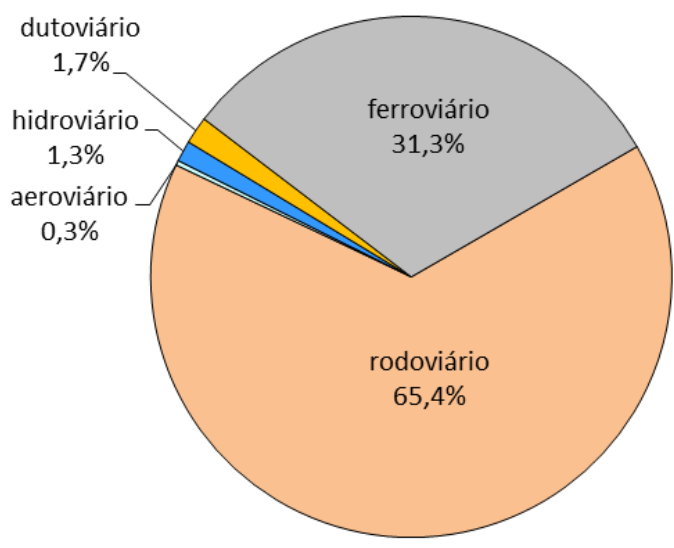

Ilustração 2.42 - Metas de migração modal do Plano Diretor de Desenvolvimento de Transportes do Estado de São Paulo

Fonte: Elaborado pelo autor com base em dados do PDDT. 
Com base nessas ilustrações observam-se contextos e metas muito diferentes entre os dois casos. Infelizmente, não foram encontras informações como essa desejada migração está de fato ocorrendo. Assumindo que os dados de 2005 reflitam a realidade, de 1996 a este ano, a migração de cargas do modal rodoviário para os demais no Brasil se deu a razão de 0,63\% ao ano. A partir de 2005, a meta é que essa migração ocorra à razão de 1,4\% ao ano, praticamente o mesmo número do plano paulista.

O aperfeiçoamento ou a instituição de novas infraestruturas viárias requerem em geral, como indicam esses planos, elevados investimentos, mas muitas vezes ações relativamente simples, como a regulação do horário de carregamento e descarregamento ou o financiamento de veículos novos, se bem planejados, podem causar grandes impactos positivos. 


\section{REVISÃO DOS PRINCIPAIS MODELOS DE INVENTÁRIOS}

Existem diversas ferramentas para inventariar e projetar o consumo e as emissões veiculares, algumas de órgãos oficiais, outras de entidades privadas. Os modelos e programas de inventários são desenvolvidos, sobretudo, para a realização de prognósticos que suportem a elaboração de políticas públicas e de planos estratégicos a eles associados. Algumas vezes, sua aplicação tem caráter compulsório para o cumprimento de compromissos formais, como, por exemplo, o modelo do IPCC destinado a inventariar as emissões de GEE nacionais, ou requisitos legais, como, por exemplo, o programa "MOVES" da USEPA, descritos adiante.

Obviamente, dependendo do objetivo perseguido, os modelos têm diferentes níveis de detalhamento e de dados disponíveis. O tipo de informação necessária para realizar, por exemplo, o inventário nacional de gases de efeito estufa (MCT, 2006) é significativamente diferente daquele necessário para avaliar o impacto na poluição atmosférica da implantação de um corredor de ônibus (CASTRO, STRAMBI, 2010).

Convém aqui mais uma vez lembrar que há uma relação direta entre o consumo de combustível e a emissão de $\mathrm{CO}_{2}$ e, apesar de causarem diferentes impactos, que há um forte vínculo entre as outras emissões veiculares de GEE e de poluentes tóxicos. No caso do $\mathrm{CH}_{4}$ e do $\mathrm{N}_{2} \mathrm{O}$, que apesar de serem, no contexto de fontes móveis rodoviárias, por sua natureza e relativamente baixos volumes emitidos, gases de baixa toxicidade, a forma de mitigar suas emissões está intimamente correlacionada com os sistemas de controle de emissões tóxicas. Além disso, muitas emissões tóxicas são também precursoras de GEE e, por isso, identificadas como GEE indiretos.

O objetivo deste capítulo é fazer uma revisão comparativa das principais características dos mais representativos modelos e programas de inventário de consumo e emissões veiculares oficiais, de domínio público, para identificar-se a ferramenta mais adequada para o propósito deste trabalho.

Como será visto adiante, existem muitos pontos em comum entre eles, mas também diferenças decorrentes, em geral, da disponibilidade ou não de dados, o que constitui a principal restrição para a aplicação das ferramentas mais sofisticadas.

Dispostos em uma sequência para facilitar sua compreensão, por sua importância, atualidade, abrangência, e por serem o resultado do trabalho coletivo de diversas expressivas instituições 
vinculadas à área, foram selecionados os seguintes modelos e programas brasileiros e internacionais:

- Modelo do "2006 IPCC Guidelines for National Greenhouse Gas Inventories”.

- Modelo do "Segundo Inventário Brasileiro de Emissões Antrópicas de Gases de Efeito Estufa no Transporte Rodoviário".

- Modelo do “EMEP/EEA Emission Inventory Guidebook 2009”.

- Modelo do "1º Inventário Nacional de Emissões Atmosféricas por Veículos Automotores Rodoviários".

- Programa MOVES2010 da USEPA.

\subsection{IPCC Guidelines for National Greenhouse Gas Inventories}

Esse guia de procedimentos é o produto do desenvolvimento cooperativo do IPCC. Sua versão mais recente é o "2006 IPCC Guidelines for National Greenhouse Gas Inventories" (IPCC, 2006). As versões anteriores foram divulgadas em 1996 e 2000. O Capítulo 3 desse guia do IPCC, intitulado "Mobile Combustion", trata das emissões de GEE geradas por fontes móveis associadas ao consumo de energia, particularmente de $\mathrm{CO}_{2}, \mathrm{CH}_{4}$ e $\mathrm{N}_{2} \mathrm{O}$.

Outras emissões de fontes móveis com impacto no clima, como emissões de GEE indiretos, isto é, emissões de substâncias precursoras de GEE, por ex. CO, COVNM, $\mathrm{SO}_{2}, \mathrm{MP}$ e $\mathrm{NO}_{\mathrm{X}}$, em geral regulamentadas por sua toxidade, e de GEE utilizados nos aparelhos de ar condicionado dos veículos, são tratados separadamente.

Apesar da emissão de GEE veicular ser predominantemente decorrente de combustão, há ainda alguma contribuição de emissões evaporativas dos combustíveis e da decomposição da ureia em amônia, quando esta é utilizada em sistemas SCR.

O subcapítulo 3.2 "Road Transportation" desse guia trata especificamente das emissões de GEE dos veículos rodoviários. Dado que nos motores de combustão, os combustíveis são oxidados em quase sua totalidade e que as emissões de $\mathrm{CH}_{4}$ e $\mathrm{N}_{2} \mathrm{O}$, em volumes significativamente menores que de $\mathrm{CO}_{2}$, estão fortemente vinculadas ao tipo de tecnologia de controle de emissões tóxicas empregada, é aplicado um critério para o $\mathrm{CO}_{2}$ e outro para $\mathrm{CH}_{4} \mathrm{e}$ $\mathrm{N}_{2} \mathrm{O}$. Além disso, dependendo do tipo de dado disponível, recomenda-se a aplicação de um ou 
outro procedimento e modelo ("tiers"). Em ambos os casos são apresentadas árvores de decisão para, em função do tipo de dado disponível, escolher-se o procedimento a ser seguido.

\section{Emissão de $\mathrm{CO}_{2}$ "Tiers" 1 e 2}

Para estimar-se a emissão de $\mathrm{CO}_{2}$ assume-se que a combustão é completa e aplica-se o modelo expresso pela seguinte equação:

$$
\text { Emissão }_{\mathrm{CO} 2}=\sum_{f}\left[\text { Consumo }_{f} \times \mathrm{FE}_{\mathrm{CO} 2, f}\right]
$$

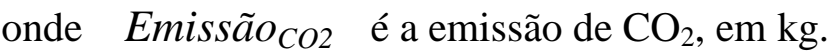

Consumo $_{f}$ é o consumo do combustível $f$ (ex. gasolina, etc.), em TJ.

$F E_{C O 2, f} \quad$ é o fator de emissão de $\mathrm{CO}_{2}$, em kg/TJ, do combustível $f$.

Caso não se disponha dos conteúdos regionais de carbono específicos dos combustíveis, serão utilizados fatores de emissão pré-estabelecidos (“default”), e nesse caso o método é classificado como "Tier 1". Caso se disponha e se utilize os conteúdos de carbono regionais, e seja levada em conta a emissão de carbono emitido não $\mathrm{CO}_{2}$, o método será classificado como “Tier 2". No que tange à emissão de $\mathrm{CO}_{2}$, não existe "Tier 3".

Em princípio, a aplicação dessa equação para biocombustíveis serve somente para relatar o resultado sem que este deva ser considerado no cômputo das emissões totais. Isso porque as emissões líquidas de GEE dos biocombustíveis, segundo as recomendações do IPCC, são computadas no "Volume 4 - Agricultura, Floresta e Outros Usos da Terra" (AFOLU, sigla em inglês) do referido guia do IPCC.

Caso sejam utilizados sistemas de pós-tratamento com injeção de ureia, deve ser somada à emissão de $\mathrm{CO}_{2}$ anterior a emissão calculada pela expressão:

$$
\text { Emissão }_{\mathrm{CO} 2}=\text { Consumo }_{\text {solução }} \times \frac{12}{60} \times \text { Concentração } \times \frac{44}{12}
$$

onde Emissão $\mathrm{CO}_{2}$ é a emissão de $\mathrm{CO}_{2}$, em $\mathrm{Gg}$.

Consumo $_{\text {solução }}$ é o consumo de solução de ureia, em Gg.

Concentração é a porcentagem em massa de ureia na solução. 


\section{Emissão de $\mathrm{CH}_{4}$ e $\mathrm{N}_{2} \mathrm{O}$ "Tier 1"}

Ao contrário da emissão de $\mathrm{CO}_{2}$, como as emissões de $\mathrm{CH}_{4}$ e $\mathrm{N}_{2} \mathrm{O}$ dependem da tecnologia veicular, combustíveis e condições de operação, o uso de dados de consumo total leva a resultados com grande incerteza. Nesse caso, dados específicos de consumo por classes de tecnologia veicular, combustíveis e condições de operação ou baseados em quilometragem acumulada proporcionam resultados mais robustos. As emissões de $\mathrm{CH}_{4}$ e $\mathrm{N}_{2} \mathrm{O}$ dos biocombustíveis também devem ser computadas nas emissões totais.

Caso não se disponha de melhores dados, as emissões de $\mathrm{CH}_{4}$ e $\mathrm{N}_{2} \mathrm{O}$ podem ser calculadas por meio da Equação 3.3, método classificado como "Tier 1".

$$
\text { Emissão }_{p}=\sum_{f}\left[\text { Consumo }_{f} \times F E_{p, f}\right]
$$

onde Emissão $o_{p}$ é a emissão de $\mathrm{CH}_{4}$ ou $\mathrm{N}_{2} \mathrm{O}$, em kg.

Consumo $_{f}$ é o consumo de combustível $f$, em TJ.

$F E_{p, f} \quad$ é o fator de emissão pré-estabelecido de $\mathrm{CH}_{4}$ ou $\mathrm{N}_{2} \mathrm{O}$, em kg/TJ, relativo ao combustível $f$, obtidos na Tabela 3.2.2 desse guia.

A título de ilustração, parte dos fatores de emissão pré-definidos da Tabela 3.2.2 desse guia é reproduzida na Tabela 3.1 a seguir.

Convém ressaltar que esse guia destaca que os fatores de emissão pré-definidos podem ser muito diferentes daqueles que podem ser observados nos países em desenvolvimento, em função de diferenças, por exemplo, na composição e condição de manutenção da frota. Em função disso, ele sugere que sejam feitos levantamentos específicos na região de interesse.

O guia do IPCC também recomenda considerar-se o teor de enxofre do combustível, uma vez que os sistemas de controle de emissões podem ter seu desempenho e durabilidade significativamente afetados por esta grandeza. Porém, lembrando que nesta década o Brasil conviverá por alguns anos com três ou quatro diferentes teores de enxofre no óleo diesel (S1800, S500, S50 e S15), contexto muito diferente dos países desenvolvidos, é possível inferir que não será fácil obter-se dados que reproduzam adequadamente essa realidade. 
Tabela 3.1 - Fatores de emissão pré-definidos dos principais combustíveis veiculares no "2006 IPCC Guidelines for National GHG Inventories"

\begin{tabular}{ccccc}
\hline Combustível $^{(1)}$ & $\begin{array}{c}\text { Tecnologia } \\
\text { ou aplicação }\end{array}$ & $\begin{array}{c}\mathbf{C O}^{(2)} \\
{[\mathrm{kg} / \mathrm{TJ}]}\end{array}$ & $\begin{array}{c}\mathbf{C H}_{\mathbf{4}}{ }^{(3)} \\
{[\mathrm{kg} / \mathrm{TJ}]}\end{array}$ & $\begin{array}{c}\mathbf{N}_{\mathbf{2}} \mathbf{O}^{(3)} \\
{[\mathrm{kg} / \mathrm{TJ}]}\end{array}$ \\
\hline gasolina & $\begin{array}{c}\text { sem controle } \\
\text { catalisador de oxidação }\end{array}$ & 69.300 & 33 & 3,2 \\
& Tier I $^{(4)}$ novos & & 25 & 8,0 \\
óleo diesel & - & 74.100 & 3,8 & 5,7 \\
gás natural & - & 56.100 & 92 & 3,9 \\
GLP & - & 63.100 & 62 & 3 \\
etanol & caminhões (EUA) & 0 & 260 & 0,2 \\
& automóveis (BR) & & 18 & 41 \\
\hline
\end{tabular}

Fonte: IPCC, 2006, pg. 3.16, et seq.

Notas:

(1) No caso de misturas de combustíveis fósseis com biocombustíveis, como a gasolina C brasileira, deve-se segregar a parcela do combustível fóssil da parcela do combustível renovável.

(2) Baseados no poder calorífico inferior. Sugere-se que antes de sua aplicação, verifique-se se eles são compatíveis com os combustíveis locais.

(3) Assumindo-se as seguintes eficiências para veículos a: gasolina $10 \mathrm{~km} / \mathrm{l}$; diesel $5 \mathrm{~km} / \mathrm{l}$; gás natural $9 \mathrm{~km} / \mathrm{l}$; etanol $9 \mathrm{~km} / \mathrm{l}$.

(4) Nesse caso "Tier I" refere-se à classe de limite de emissões veiculares estadunidense, que corresponde a classe hoje em implementação no Brasil.

(5) O balanço da emissão de $\mathrm{CO}_{2}$ de biocombustíveis é tratada pelo setor AFOLU do estudo do IPCC.

\section{Emissão de $\mathrm{CH}_{4}$ e $\mathrm{N}_{2} \mathrm{O}$ “Tier 2"}

Caso se disponha de fatores de emissão baseados no consumo de combustíveis, específicos para cada classe de veículos (ex. motociclos, automóveis, caminhões, etc.) e tecnologia de controle de emissões, utiliza-se a Equação 3.4, método classificado como “Tier 2".

$$
\text { Emissão }_{p}=\sum_{f, v, t}\left[\text { Consumo }_{f, v, t} \times F E_{p, f, v, t}\right]
$$

onde Emissão é a emissão de $\mathrm{CH}_{4}$ ou $\mathrm{N}_{2} \mathrm{O}$, em kg.

Consumo $_{f, v, t}$ é o consumo do combustível $f$, em TJ, da classe de veículo $v$ (ex. motociclo, automóvel, etc.), com tecnologia de controle de emissões $t$ (ex. sem catalisador, com catalisador de oxidação ou de três vias).

$F E_{p, f, v, t}$ é o fator de emissão de $\mathrm{CH}_{4}$ ou $\mathrm{N}_{2} \mathrm{O}$, em kg/TJ, relativo ao combustível $f$, da classe de veículo $v$, com tecnologia de controle de emissões $t$. 


\section{Emissão de $\mathrm{CH}_{4}$ e $\mathrm{N}_{2} \mathrm{O}$ "Tier 3"}

Finalmente, caso se disponha de fatores de emissão baseados na distância percorrida, específicos para cada combustível, classe de veículos, tecnologia de controle de emissões e condição de operação, utiliza-se a Equação 3.5, método classificado como “Tier 3”. Esse é o único método que não usa como dado de entrada o consumo de combustível.

$$
\text { Emissão }_{p}=\sum_{f, v, t, o}\left[V K T_{f, v, t, o} \times F E_{p, f, v, t, o}\right]+\sum_{f, v, t, o} C_{p, f, v, t, o}
$$

onde Emissão $o_{p}$ é a emissão de $\mathrm{CH}_{4}$ ou $\mathrm{N}_{2} \mathrm{O}$, em kg.

$V K T_{f, v, t, o}{ }^{75}$ é a quilometragem anual acumulada ${ }^{76}$, com o combustível $f$, da classe de veículo $v$, com tecnologia de controle de emissões $t$, na condição de operação 0 . (ex. urbano ou estrada, clima, etc.).

$F E_{p, f, v, t, o}$ é o fator de emissão de $\mathrm{CH}_{4}$ ou $\mathrm{N}_{2} \mathrm{O}$, em $\mathrm{kg} / \mathrm{km}$, relativo ao combustível $f$, da classe de veículo $v$, com tecnologia de controle de emissões $t$, na condição de operação $o$.

$C_{p, f, v, t, o} \quad$ emissões de $\mathrm{CH}_{4}$ ou $\mathrm{N}_{2} \mathrm{O}$, em $\mathrm{kg}$, durante a fase de aquecimento após partida a frio, com o combustível $f$, da classe de veículo $v$, com tecnologia de controle de emissões $t$, na condição de operação $o$.

Se não houver dados segmentados por tipo de via (ex. urbano, estrada, etc.), pode-se dispensar seu uso. O guia do IPCC apresenta os fatores de emissão em $\mathrm{kg} / \mathrm{km}$ levantados pela USEPA (Tabelas 3.2.3 e 3.2.4) e pela Comunidade Europeia (Tabela 3.2.5).

Observar que essa expressão possui um termo adicional $\left(C_{p, f, v, t, o}\right)$ para reproduzir as emissões extras que ocorrem após a partida dos veículos, durante a fase de aquecimento, condição na qual as emissões são significativamente superiores àquelas observadas com o veículo em condições de temperatura de operação estabilizada. Pesquisas demonstram que até que os

\footnotetext{
75 Adotou-se VKT, o acrônimo de "vehicle kilometers traveled", porque dados dessa natureza são assim referenciados na bibliografia internacional. É comum também encontrar-se VMT, acrônimo de "vehicle miles traveled".

${ }^{76}$ Essa distância é usualmente decrescente em função da idade do veículo.
} 
motores e os conversores catalíticos ${ }^{77}$ atinjam temperaturas de operação adequada, transcorrem cerca de três a quatro minutos ou cerca de três quilômetros. Essa emissão adicional é estimada pela USEPA por meio do número de partidas por veículo por ano. Já o modelo de inventário europeu do Guia EMEP/EEA, derivado do COPERT 4, utiliza expressão em função da temperatura.

Como recomenda a boa prática, esse guia reforça que todas as premissas e valores utilizados sejam claramente identificados e relatados.

\subsection{Segundo Inventário Brasileiro de Emissões Antrópicas de Gases de Efeito Estufa no Transporte Rodoviário}

O Segundo Inventário Brasileiro de Emissões de Gases de Efeito Estufa no Transporte Rodoviário (BRASIL 2010) é o resultado de um trabalho coordenado pelo MCT, em parceria com a OSCIP Economia e Energia (E\&E) e do Ministério de Minas e Energia (MME).

Ele apresenta as estimativas das emissões dos GEE diretos $\left(\mathrm{CO}_{2}, \mathrm{CH}_{4}\right.$ e $\left.\mathrm{N}_{2} \mathrm{O}\right)$ e indiretos $(\mathrm{CO}$, $\mathrm{NO}_{\mathrm{X}}$ e COVNM), devidas ao consumo de energia do modal rodoviário, no período de 1990 a 2005. Essas estimativas foram feitas com base na abordagem mais detalhada das Diretrizes Revisadas de 1996 do IPCC. Convém lembrar que a versão mais recente desse guia, descrito acima, é de 2006.

No Primeiro Inventário (BRASIL 2006), o modelo utilizado para veículos leves era representado pela equação abaixo.

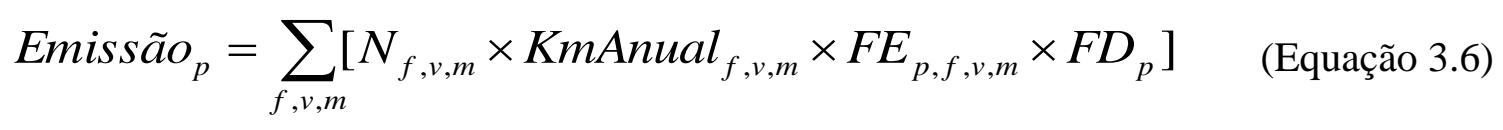

onde Emissão $_{p} \quad$ é a emissão anual do poluente $p$, em g.

$N_{f, v, m} \quad$ é o número de veículos que rodam com o combustível $f$, da classe de veículo $v$, do ano modelo $m^{78}$.

\footnotetext{
${ }^{77}$ Os conversores catalíticos operam em regime somente após atingirem cerca de $300{ }^{\circ} \mathrm{C}$ ("light-off threshold").

${ }^{78}$ No documento original, $N_{f, v, m}$ e KmAnual ${ }_{f, v, m}$ estão representados respectivamente por $F N C$ (frota nacional circulante) ou $F_{g, t}$ (frota de veículos movido a combustível $g$ produzidos no ano $t$ em circulação no referido ano) e $D M_{g, t}$ (distância média anual percorrida pelos veículos movidos a combustível $g$ produzidos no ano $t$, em km). Estas distâncias foram estimadas pela PETROBRAS em função da idade do veículo, do preço do combustível e do nível de renda da população. O produto deles é igual à $V K T_{f, v, m}$.
} 
$\operatorname{KmAnual}_{f, v, m}$ é quilometragem média anual por veículo, daqueles que rodam com o combustível $f$, da classe de veículo $v$, do ano modelo $m$.

$F E_{p, f, v, m} \quad$ é o fator de emissão do poluente $p$, relativo ao combustível $f$, da classe de veículo $v$, do ano modelo $m^{79}$, em $\mathrm{g} / \mathrm{km}$.

$F D_{p} \quad$ é o fator de deterioração, função da VKT, do poluente $p$, publicados pelo EPA em $1981^{80}$.

Como a multiplicação do número de veículos $\left(N_{f, v, m}\right)$ pela quilometragem média anual $\left(K_{m A n u a l}, v, m\right)$ corresponde a quilometragem anual acumulada $\left(V K T_{f, v, t}\right)$, essa equação é semelhante à Equação 3.5 acima do "Tier 3" do "2006 IPCC Guidelines". No entanto, além do modelo aqui adotado até o momento não considerar a influência da condição de operação (índice $o$ ), cuja consideração é nesse guia, de qualquer forma, uma opção, nem das emissões adicionais durante a fase de aquecimento $\left(C_{p, f, v, t, o}\right)$, existem também diferenças na qualidade da base de dados dos demais aspectos considerados.

Por falta de dados mais robustos, para inferir-se a composição da frota, utilizou-se o número de veículos vendidos ou licenciados e curvas de sucateamento utilizadas pelo Serviço de Planejamento da PETROBRAS, calibradas pelos dados da PNAD de 1988. As quilometragens anuais utilizadas foram estimativas da PETROBRAS feitas em função da idade do veículo, do preço do combustível e do nível de renda da população.

Os fatores de emissão utilizados, em geral, foram aqueles divulgados pela CETESB, baseados nas médias ponderadas dos valores observados nos processos de homologação de cada modelo de veículo pelo volume da produção desse modelo no ano considerado. Os fatores de COVNM foram calculados com base nas emissões de $\mathrm{HC}$ menos $\mathrm{CH}_{4}$ no escape, somado as emissões evaporativas. Na realidade, em função da deterioração dos sistemas de controle de emissões dos veículos em uso, os fatores de emissão reais da frota devem ser significativamente superiores àqueles observados nos processos de homologação. Já os fatores de $\mathrm{CO}_{2}$ e $\mathrm{N}_{2} \mathrm{O}$ utilizados são os valores sugeridos pelo IPCC.

Já para os veículos pesados, o modelo utilizado era representado pela seguinte equação.

\footnotetext{
${ }^{79}$ No documento original, $F E_{p}$ está representado por $F E_{g, t}$ (fator de emissão do gás $g$ característico dos veículos produzidos no ano $t$, em $\mathrm{g} / \mathrm{km})$.

${ }^{80}$ No documento original, $F D_{p}$ está representado por $F D_{g, t}$ (fator de deterioração do gás $g$ pelos veículos produzidos no ano $t$, no referido ano).
} 
Emissão $_{p}=\sum_{v}\left[\right.$ Consumo $\left._{v} \times F E_{p}\right]$

onde Emissão $o_{p}$ é a emissão do GEE $p$, em gramas.

Consumo $_{v}$ é o consumo de óleo diesel, da classe de veículo $v$, em litros.

$F E_{p} \quad$ é o fator de emissão pré-estabelecido do GEE $p$, em g/litro de óleo diesel.

Essa equação é semelhante à Equação 3.4 acima do "Tier 2" do "2006 IPCC Guidelines", ressalvando que a equação acima está se referindo somente a um combustível (índice f), o óleo diesel, e, pelo fato do período considerado ser de 1990 a 1994, somente à uma classe de tecnologia de controle de emissões (índice $t$ ), a pré-Euro I, fase anterior a implantação de limites legais. Ou seja, as emissões dos veículos pesados eram estimadas com base no consumo do diesel e não nos tamanhos das frotas e suas correspondentes quilometragens média anual, procedimento aplicado para os veículos leves.

Os fatores de emissão dos compostos regulados $\left(\mathrm{CO}, \mathrm{HC}\right.$ e $\left.\mathrm{NO}_{\mathrm{X}}\right)$, em g/litro, foram estimados a partir dos limites de emissões em $\mathrm{g} / \mathrm{kW}$.h vigentes no período, da média dos consumos específicos mínimos anteriores e de um valor médio da densidade do óleo diesel. Para $\mathrm{CH}_{4}$, $\mathrm{N}_{2} \mathrm{O}$ e COVNM foram utilizados os valores sugeridos pelo IPCC. Para o $\mathrm{CO}_{2}$ utilizou-se a relação estequiométrica supondo-se a combustão completa de um óleo diesel médio estimado a partir do número cetano típico observado nas refinarias.

No final, o consumo e, consequentemente, as emissões totais da frota diesel foram segregadas pelas classes comerciais leves, ônibus e caminhões por meio de um "fator de rateio" calculado com base em uma estimativa das correspondentes participações dessas classes nessa frota, potências médias e consumos específicos mínimos, fornecidos pela Mercedes Benz do Brasil.

No Segundo Inventário, foi utilizado um modelo similar ao da equação anterior, porém aplicado para os consumos energéticos de gasolina $\mathrm{C}$, etanol hidratado e óleo diesel, e um fator de emissão por energia derivado dos fatores anteriores, como mostrado na equação abaixo.

$$
\operatorname{Emissão}_{p}=\sum_{f, v, m}\left[\text { Consumo }_{f, v, m} \times F E_{p, f, v, m}\right]
$$

onde Emissão $_{p} \quad$ é a emissão do GEE $p$, em gramas.

Consumo $_{f, v, m}$ é o consumo do combustível $f$, da classe de veículo $v$, do ano modelo $m$, em TJ. 
$F E_{p, f, m} \quad$ é o fator de emissão do poluente $p$, relativo ao combustível $f$, da classe de veículo $v$, do ano modelo $m$, em $\mathrm{kg} / \mathrm{TJ}$.

O cálculo da composição da frota também foi alterado. No lugar das curvas de sucateamento da PETROBRAS, utilizaram-se curvas de sucateamento obtidas por funções logísticas ajustadas para uma estimativa da composição da frota realizada pelo DENATRAN em 1997. A distribuição do consumo por categoria de veículo foi feita com base nas frotas estimadas e uma tabela de consumos relativos estimados.

\subsection{EMEP/EEA Air Pollutant Emission Inventory Guidebook 2009}

Este guia tem por objetivo principal inventariar as emissões tóxicas, porém de forma compatível e coordenada com o guia do IPCC, que foca as emissões de GEE. Ele reúne os mais significativos métodos de estimativas de emissões utilizados na Europa e região da Comissão Econômica para a Europa das Nações Unidas (UNECE, sigla em inglês). Para melhor entender a relevância dos inventários de emissões, sobretudo no contexto europeu, e a importância dessa ferramenta, é fundamental conhecer as entidades envolvidas em seu desenvolvimento e o histórico de sua evolução.

Sob o patrocínio da UNECE, foi adotada em 1979 pela Comunidade Econômica Europeia (EEC, sigla em inglês) a Convenção sobre a Poluição Atmosférica Transfronteiriça a Longa Distância (CLRTAP, sigla em inglês). Visando atender as metas da CLRTAP, foi criado um projeto cooperativo denominado o Programa Europeu de Avaliação e Monitoramento (EMEP, sigla em inglês).

Em 1985, o Conselho Europeu de Ministros estabeleceu a Coordenação de Informações Ambientais (CORINE, sigla em francês), o qual por sua vez constituiu um projeto para compilar informações sobre emissões atmosféricas, denominado Corinair. De 1986 a 2000, o Corinair 1985, como foi denominado essa fase do projeto, inventariou os poluentes $\mathrm{SO}_{2}, \mathrm{NO}_{\mathrm{X}} \mathrm{e}$ COV de oito setores econômicos, principais causadores desse tipo de poluição. Esse projeto, entre outras coisas, também desenvolveu a Nomenclatura Selecionada para Poluição do Ar (SNAP, sigla em inglês).

Em 1990, a União Europeia (EU, sigla em inglês) criou a Agência Europeia do Ambiente (EEA, sigla em inglês), a qual foi instituída, de fato, no final de 1993, em Copenhague. Para suportar tecnicamente a EEA, parte dos países membros da EU se consorciou para criar cinco 
centros técnicos de excelência sobre tópicos específicos, cuja coordenação é feita pela própria EEA. Para tratar de questões relacionadas às emissões atmosféricas foi instituído o Centro Tópico Europeu sobre Emissões Atmosféricas (ETC/AE, sigla em inglês) ${ }^{81}$.

Além dos ETCs, a EEA recebe o suporte de cerca de novecentos especialistas de diversas entidades ambientais dos 38 países membros. A esse conjunto que foi constituído denominouse Rede Europeia de Informação e de Observação do Ambiente (EIONET, sigla em inglês).

Em 1991, visando uniformizar e harmonizar procedimentos e dados, o Corpo Executivo do EMEP estabeleceu a Força Tarefa para Inventários de Emissões e Projeções (TFEIP, sigla em inglês). Nesse mesmo ano, a CORINE em cooperação com o EMEP, o IPCC e a OECD, decidiram desenvolver uma atualização do Corinair

A essa nova fase do projeto denominou-se Corinair 1990. Essa atualização, além de compatibilizar seus produtos às regras do CLRTAP e da UNFCCC, levou em consideração a necessidade de tornar os inventários mais abrangentes, consistentes e transparentes.

O Corinair 1990 ampliou, sobretudo, o número de fontes de emissão; o número de poluentes, agora $\mathrm{SO}_{2}, \mathrm{NO}_{\mathrm{X}}, \mathrm{COVNM}, \mathrm{CO}, \mathrm{CH}_{4}, \mathrm{~N}_{2} \mathrm{O}, \mathrm{CO}_{2}$ e amônia $\left(\mathrm{NH}_{3}\right)$; a nomenclatura, agora denominada SNAP90; e ampliou sua cobertura de 12 para 30 países da UNECE. Seus resultados foram divulgados pela EEA de 1996 a 1997.

Mesmo antes do início da divulgação do Corinair 1990, em 1994, a EEA, por meio do ETC/AE, começou o desenvolvimento de uma nova metodologia e programa de inventário que foram denominados Corinair 1994. Esse inventário abrangia 31 países e foi divulgado pela EEA ainda em 1997.

Em 1998, visando assegurar a compatibilidade entre o guia e os padrões de relatórios do Inventário de Emissões Atmosféricas do EMEP/Corinair e seus correspondentes do IPCC, a Unidade Técnica do Corinair, acompanhado do ETC/AE, trabalhando em parceria com o IPCC, a OECD e a Agência Internacional de Energia (IEA, sigla em inglês), divulgou o SNAP97.

Resumidamente, o "EMEP/EEA air pollutant emission inventory guidebook 2009 - Technical guidance to prepare national emission inventories" (EEA, 2009) é o resultado do trabalho realizado pelo EMEP em parceria com a UNECE, por meio da TFEIP, para reestruturar e atualizar o guia de inventário de emissões EMEP/Corinair, atendendo tanto aos “Guidelines for

\footnotetext{
${ }^{81}$ Atualmente denominado "European Topic Centre on Air and Climate Change" (ETC/ACC).
} 
Reporting Emission Data" da CLRTAP como a "EU National Emission Ceiling Directive" (Diretiva 2001/81/EC).

Ao contrário da versão anterior, que era estruturada de acordo com a SNAP da EEA, a versão atual utiliza a Nomenclatura para Relatar (NFR, sigla em inglês), integrante da CLRTAP da UNECE. Visando permitir uma perspectiva de continuidade, o guia atual apresenta a correlação entre a SNAP e a NFR. Além da NFR ser semelhante à nomenclatura utilizada pelo IPCC, o "EMEP/EEA guidebook 2009” é compatível e complementar ao "2006 IPCC Guidelines".

Sob do Capítulo "1. Energy", subcapítulo "1.A. Combustion”, os itens de 1.A.3.b.i a 1.A.3.b.iv tratam das emissões de escapamento derivados do transporte rodoviário; o item 1.A.3.b.v trata das emissões evaporativas; e os itens 1.A.3.b.vi e 1.A.3.b.vii tratam das emissões derivadas do desgaste dos pneus, freios e pavimentos.

As emissões cobertas pelo subcapítulo "1.A Combustion" são: $\mathrm{CO}, \mathrm{NO}_{\mathrm{X}}, \mathrm{COVNM}, \mathrm{CH}_{4}, \mathrm{CO}_{2}$, $\mathrm{N}_{2} \mathrm{O}, \mathrm{NH}_{3}$, óxidos de enxofre $\left(\mathrm{SO}_{\mathrm{X}}\right), \mathrm{MP}, \mathrm{HPA}$, poluentes orgânicos persistentes (POP), dioxinas, furanos e metais pesados contidos no combustível, tais como chumbo $(\mathrm{Pb})$, cádmio, cobre, cromo, níquel, selênio e zinco. O material particulado é também subdividido em carbono elementar e carbono orgânico; e os COVNM em famílias de compostos como alcanos, alcenos, alcinos, aldeídos, cetonas e aromáticos. Como o material particulado de veículos é predominantemente de tamanho inferior a 2,5 $\mu \mathrm{m}$, os fatores de emissão de MP desse guia referem-se somente a $\mathrm{MP}_{2,5}$, havendo também fatores de emissão para número e área superficial do MP.

O cálculo desses poluentes, no entanto, é segmentado em função do tipo de dado disponível. Por exemplo, para os poluentes tóxicos usualmente regulamentados e controlados, para os quais existem fatores de emissão para diferentes condições de uso, aplica-se metodologia detalhada que permite considerar esses aspectos (Grupo 1). Poluentes diretamente associados ao combustível, como $\mathrm{CO}_{2}, \mathrm{SO}_{2}$ e metais pesados, são estimados com base em seu consumo (Grupo 2). Para HPA, POP, dioxinas e furanos, para os quais não existem dados detalhados, utiliza-se metodologia simplificada (Grupo 3). Alcanos, alcenos, alcinos, aldeídos, cetonas, cicloalcanos e aromáticos são frações derivadas da emissão total de COVNM (Grupo 4).

A semelhança do que ocorre no guia do IPCC, a opção da metodologia a ser aplicada é auxiliada por uma árvore de decisão. E assim como o guia do IPCC, as metodologias estão divididas em "tiers". 


\section{“Tier 1"}

Para a aplicação método "Tier 1" é necessário terem-se os dados de consumo segregados pelas classes de veículos. Na falta de dados primários, o guia sugere que os consumos de cada classe de veículo sejam estimados com base na quilometragem acumulada anual, ou seja, em função da condição de uso local, e o correspondente consumo de combustível típico da classe, em kg/km, apresentados na Tabela 3-13 desse guia (EMEP/EEA, 2009, cap. 1.A.3.b.i-iv, p.23).

Para estimarem-se as emissões segundo esse método, aplica-se o modelo expresso pela seguinte equação:

$$
{\text { Emiss } \tilde{a} o_{p}}_{=} \sum_{f, v}\left[\text { Consumo }_{f, v} \times F E_{p, f, v}\right]
$$

onde Emissão $o_{p}$ é a emissão do poluente $p$, em g.

Consumo $_{f, v}$ é o consumo de combustível $f$, em kg, da classe de veículo $v$.

$F E_{p, f, v} \quad$ é o fator de emissão do poluente $p$, em $\mathrm{g} / \mathrm{kg}$ de combustível, relativo ao combustível $f$, da classe de veículo $v$.

Os fatores de emissão pré-definidos desse guia para o método "Tier l" foram calculados utilizando a metodologia "Tier 3", assumindo-se frota e condição de uso típicos de cada país constituinte do EU-15 $5^{82}$ em 1995. Como por força das legislações, os veículos da EU a partir dessa data ficaram mais limpos, o uso desses fatores pré-definidos tende a superestimar as emissões reais.

Nas Tabelas de 3-5 a 3-10 (Ibid, p.20-21) são apresentados os fatores de emissão em g/kg de combustível para CO, COVNM, $\mathrm{NO}_{\mathrm{X}}, \mathrm{MP}, \mathrm{N}_{2} \mathrm{O}, \mathrm{NH}_{3}, \mathrm{ID}(1,2,3-\mathrm{cd}), \mathrm{B}(\mathrm{k}) \mathrm{F}, \mathrm{B}(\mathrm{b}) \mathrm{F}, \mathrm{B}(\mathrm{a}) \mathrm{P}^{83} \mathrm{e}$ $\mathrm{Pb}$, e também de GEE. Por exemplo, na Tabela 3-11 (Ibid, p.21) são apresentados os fatores de emissão de $\mathrm{CO}_{2}$, expressos em $\mathrm{kg}_{\mathrm{CO} 2}$ por $\mathrm{kg}$ de combustível. Além de fatores de emissão médios, são ainda apresentados valores máximos, correspondentes a veículos pré-controle de emissões, e valores mínimos, correspondentes a veículos pré-EURO 4.

Com relação ao enxofre (S), assume-se que todo $\mathrm{S}$ contido no combustível é oxidado e convertido em $\mathrm{SO}_{2}$. Consequentemente, para seu cálculo utiliza-se a equação a seguir.

\footnotetext{
${ }^{82}$ EU-15: Alemanha, Áustria, Bélgica, Dinamarca, Espanha, Finlândia, França, Grécia, Holanda, Irlanda, Itália, Luxemburgo, Portugal, Reino Unido e Suécia.

${ }^{83}$ Representações, respectivamente, dos seguintes hidrocarbonetos policíclicos aromáticos (PAH): indeno(1,2,3cd)pireno; benzo[k]fluoranteno; benzo[b]fluoranteno; benzo[a]pireno.
} 
${\text { Emiss } \tilde{a} o_{S O 2}}=2 \times k_{S, f} \times$ Consumo $_{f}$

(Equação 3.10)

onde Emissãos ${ }_{\mathrm{SO} 2}$ é a emissão de $\mathrm{SO}_{2}$, em g.

$k_{S, f} \quad$ é teor de enxofre no combustível, em $\mathrm{g}_{\mathrm{S}} / \mathrm{g}$ de combustível.

Consumo $_{f}$ é o consumo de combustível $f$, em g.

Para tanto, na Tabela 3-12 (Ibid, p.22) são apresentados os teores de enxofre da gasolina e óleo diesel médios do mercado europeu ao longo dos anos.

\section{“Tier 2"}

Caso haja dados consistentes sobre a condição de uso, ou mais especificamente sobre a quilometragem acumulada anual de cada classe de veículo segmentada por tecnologia de controle de emissões ${ }^{84}$, utiliza-se o método classificado como "Tier 2", expresso pelas seguintes equações:

$$
\begin{aligned}
& \text { Emissão }_{p}=\sum_{f, v, t}\left[V K T_{f, v, t} \times F E_{p, f, v, t}\right] \\
& \text { Emissão }_{p}=\sum_{f, v, t}\left[N_{f, v, t} \times \text { KmAnual }_{f, v, t} \times F E_{p, f, v, t}\right]
\end{aligned}
$$

onde Emissão $o_{p}$ é a emissão do poluente $p$, em g.

$V K T_{f, v, t} \quad$ é a quilometragem anual acumulada, com o combustível $f$, da classe de veículo $v$, com tecnologia de controle de emissões $t$.

$F E_{p, f, v, t} \quad$ é o fator de emissão do poluente $p$, em g/veículo.km, relativo ao combustível $f$, da classe de veículo $v$, com tecnologia de controle de emissões $t$.

$N_{f, v, t} \quad$ é o número de veículos que rodam com o combustível $f$, da classe de veículo $v$, com tecnologia de controle de emissões $t$.

$\operatorname{KmAnual}_{f, v, t}$ é quilometragem média anual por veículo, daqueles que rodam com o combustível $f$, da classe de veículo $v$, com tecnologia de controle de emissões $t$.

\footnotetext{
${ }^{84}$ Tipicamente associada aos limites de emissões, definidos pela correspondente legislação. Ou seja, no contexto europeu essas tecnologias serão classificadas como, por exemplo, EURO 1, etc.
} 
As classes de tecnologias de controle de emissões, vinculadas à legislação europeia, são apresentadas na Tabela 3-14 (Ibid, p.24). Nas Tabelas de 3-15 a 3-24 (Ibid, p.26-31) são apresentados os fatores de emissão, expressos em g/km, para CO, COVNM, $\mathrm{NO}_{\mathrm{X}}, \mathrm{MP}_{2,5}, \mathrm{~N}_{2} \mathrm{O}$, $\mathrm{NH}_{3}$, ID(1,2,3-cd), B(k)F, B(b)F, B(a)P e Pb, para cada combinação possível de classes de veículos, tipo de combustível, porte do veículo, expresso pelo tamanho de motor ou peso do veículo, e tecnologias de controle de emissões. Para as emissões diretamente vinculadas à qualidade do combustível, como $\mathrm{SO}_{2}$ e metais pesados, é apresentado na Tabela 3-25 (Ibid, p.32) o consumo de combustível típico para cada combinação de classe de veículo, combustível e porte do veículo.

\section{"Tier 3"}

É a metodologia mais complexa desse guia ${ }^{85}$, derivada da ferramenta COPERT $4^{86}$, que pode ser aplicada caso se disponha de dados que reproduzam as emissões sob as diferentes condições de operação dos veículos. O guia sugere que essa metodologia pode ser substituída por outros modelos e ferramentas como, por exemplo, o Artemis ${ }^{87}$, o "DACH-NL Handbook of Emission Factors", o EMV (Suécia), o Liipasto (Finlândia) e o Versit (Holanda).

As emissões totais, para cada poluente e caso considerado (ex. CO, tipo de veículo e diferentes escalas espaciais e temporais), são calculadas a partir da soma das emissões segmentadas segundo os diferentes aspectos considerados, a começar pelo estado de aquecimento do veículo (motor e sistema de pós-tratamento), isto é, as emissões da fase aquecida ("hot emissions") devem ser somadas as emissões da fase fria ("cold-start emissions").

As emissões da fase aquecida devem ser calculadas de forma semelhante à metodologia "Tier 2", porém segmentadas de acordo com a condição de uso (urbano, rural e estrada) e considerando fatores como as extensões dos trajetos e velocidades típicas, a composição da frota local (número, porte e idade dos veículos) e as condições climáticas observadas ao longo do tempo. As tabelas a seguir resumem os aspectos que se sugere sejam considerados.

\footnotetext{
${ }^{85} \mathrm{Na}$ versão anterior desse guia essa metodologia era denominada "Metodologia Detalhada".

${ }^{86}$ Maiores informações sobre o COPERT 4 pode ser obtidas em http://lat.eng.auth.gr/copert/.

87 Sigla do projeto "Assessment and Reliability of Transport Emission Models and Inventory Systems", do Directorado de Transportes da Comissão Europeia, desenvolvido entre 2000 e 2007.
} 
Tabela 3.2 - "EMEP/EEA guidebook 2009 - Tier 3" - Dados de entrada

\begin{tabular}{|c|c|}
\hline Aspecto & Dados de entrada \\
\hline Combustível & Consumo por tipo de combustível \\
\hline \multirow[t]{4}{*}{ Atividade } & $\mathrm{N}^{\mathrm{o}}$ de veículos por categoria \\
\hline & $\begin{array}{l}\text { Distribuição dos veículos segundo } \\
\text { classes da legislação ambiental }\end{array}$ \\
\hline & Quilometragem por classe de veículo \\
\hline & Quilometragem por classe de via \\
\hline Condição de condução & Velocidade média por tipo de veículo e via \\
\hline \multirow[t]{3}{*}{ Outros } & Condições climáticas \\
\hline & Distância média por viagem \\
\hline & Distribuição das emissões evaporativas \\
\hline
\end{tabular}

Fonte: EMEP/EEA emission inventory guidebook 2009, 1.A.3.b.i,.., pg. 35.

Tabela 3.3 - "EMEP/EEA guidebook 2009 - Tier 3" - Variáveis intermediárias

\begin{tabular}{|c|c|}
\hline Aspecto & Variáveis intermediárias \\
\hline \multirow[t]{3}{*}{ Fatores de emissão } & $\begin{array}{l}\text { Por tipo de emissão } \\
\text { (fase fria, quente, evaporativas) }\end{array}$ \\
\hline & Por classe de veículo \\
\hline & $\begin{array}{l}\text { Por classe de via } \\
\text { (urbana, rural ou estrada) }\end{array}$ \\
\hline \multirow[t]{2}{*}{$\% \mathrm{~km}$ na fase fria } & Por mês \\
\hline & Por classe de veículo \\
\hline
\end{tabular}

Fonte: EMEP/EEA emission inventory guidebook 2009, 1.A.3.b.i,.., pg. 35.

Essa metodologia ainda sugere o uso de fatores de correção para considerar-se a influência de: diferença entre o consumo calculado e o real observado, o conteúdo de carbono, oxigênio, enxofre, chumbo e outros metais pesados dos combustíveis efetivamente utilizados, quilometragem acumulada, rampas e carregamento típico dos veículos, sobretudo os de carga.

Para o cálculo das emissões extras da fase fria, que ocorrem tipicamente durante o uso urbano e rural, utiliza-se modelo semelhante ao anterior, porém acrescido de dois fatores para reproduzir a fração da quilometragem rodada durante a fase fria e a razão das emissões fase fria-fase aquecida, para cada poluente e tecnologia de controle de emissões empregada. A fração, por sua vez, depende da temperatura ambiente e condição de uso dos veículos, em particular, da 
extensão dos trajetos típicos ${ }^{88}$. Entretanto, esse guia reforça que existem dados disponíveis para esse fim somente para veículos leves (automóveis e comerciais leves) rodando com gasolina, diesel e GLP, de uso proibido no Brasil, e ainda desconsiderando a idade dos veículos. Essa limitação é minimizada pelo fato dos veículos pesados rodarem, em grande parte, aquecidos.

O equacionamento das diversas possíveis combinações, que implicam em vários cálculos intermediários, está detalhado no referido guia. Dada sua complexidade, não conviria reproduzi-lo neste texto. De qualquer forma, a aplicação consistente dessa metodologia depende da disponibilidade e qualidade dos dados que a consubstanciem. A aplicação dessa ferramenta para a realidade brasileira depende de uma revisão crítica, e possivelmente de levantamentos estatísticos e experimentais, dos dados utilizados.

\subsection{Primeiro Inventário Nacional de Emissões Atmosféricas por Veículos Automotores Rodoviários}

O “1 Inventário Nacional de Emissões Atmosféricas por Veículos Automotores Rodoviários" (BRASIL 2011) é o resultado da parceria do MMA com o Instituto Brasileiro do Meio Ambiente e dos Recursos Naturais Renováveis (IBAMA); a ANP; a Agência Nacional de Transportes Terrestres (ANTT); a CETESB; a PETROBRAS; a ANFAVEA e o Instituto de Energia e Meio Ambiente (IEMA), para implantar o Programa Nacional de Inventários de Fontes Poluidoras do Ar, conforme estabelece o Programa Nacional de Controle da Qualidade do Ar (PRONAR), instituído pela Resolução CONAMA nº 5 de 1989.

Esse inventário apresenta estimativas das emissões dos poluentes regulamentados pelo PROCONVE, ou seja, $\mathrm{CO}, \mathrm{NO}_{\mathrm{X}}$, hidrocarbonetos não metano (HCNM), aldeídos (RCHO), MP

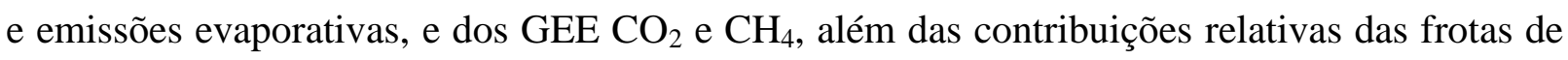
automóveis, veículos comerciais leves, ônibus, caminhões e motociclos, para as diferentes fases do PROCONVE, para o período de 1980 a 2009. Ele também apresenta projeções desses dados até 2020, baseado em algumas premissas de crescimento e dos novos limites de emissões que entrarão em vigor.

O modelo adotado para elaboração desse inventário é representado pela equação a seguir.

\footnotetext{
${ }^{88}$ Caso não se disponha de levantamento local, sugere-se, para países europeus, o uso do valor médio de $12,4 \mathrm{~km}$. No entanto, levantamentos estatísticos realizados em 1998 nessa região constataram valores médios variando de 8 a $15 \mathrm{~km}$.
} 


$$
\text { Emissão }_{p}=\sum_{f, v, t}\left[N_{f, v, t} \times \text { KmAnual }_{f, v, t} \times F E_{p, f, v, t}\right]
$$

onde Emissão $_{p}$ é a emissão anual do poluente $p$, em $\mathrm{kg}$.

$N_{f, v, t} \quad$ é o número de veículos que rodam com o combustível $f$, da classe de veículo $v$, com tecnologia de controle de emissões $t$.

$\mathrm{KmAnual}_{f, v, t}$ é quilometragem média anual por veículo, que rodam com o combustível $f$, da classe de veículo $v$, com tecnologia de controle de emissões $t .^{89}$

$F E_{p, f, v, t} \quad$ é o fator de emissão médio do poluente $p$, relativo ao combustível $f$, da classe de veículo $v$, com tecnologia de controle de emissões $t$, observado nos processos de homologação.

Observar que essa equação é semelhante à equação 3.12 do "Tier 2" do "EMEP/EEA Emission Inventory Guidebook". No entanto, como o próprio documento reconhece, a semelhança do que ocorre no caso do "Primeiro Inventário Brasileiro de Emissões Antrópicas de Gases de Efeito Estufa”, os resultados são comprometidos pela falta de dados mais robustos no que tange à composição da frota, sua condição de uso e fatores de emissões da frota em uso.

Para inferir a composição da frota, foi adotado o mesmo procedimento do Primeiro Inventário Brasileiro de Emissões Antrópicas de Gases de Efeito Estufa, sendo que a curva de sucateamento das motocicletas é a mesma utilizada pelo Sindipeças. As quilometragens anuais utilizadas, função da idade do veículo, foram estimadas a partir de estudos realizados pelo "International Sustainable Systems Research Center" (ISSRC) em parceria com a CETESB; pelo IPEA; pelo IPT e levantamento realizado pela ANFAVEA.

Como no modelo anterior, os fatores de emissão de veículos leves utilizados são aqueles divulgados pela CETESB, baseados nas médias ponderadas dos valores observados nos processos de homologação e nos ensaios de controle de produção de cada modelo de veículo pelo volume da produção desse modelo no ano considerado. Já os fatores de emissão de veículos pesados utilizados foram derivados dos resultados de ensaios de homologação, consumos específicos e estimativas de eficiências (em km/l) fornecidos pela ANFAVEA.

\footnotetext{
${ }^{89}$ No documento original, $N_{f, v, t}$ e $\mathrm{KmAnual}_{f, v, t}$ estão representados respectivamente por $\mathrm{Fr}$ (frota circulante por ano modelo) por $I u$ (intensidade de uso por ano modelo). O produto deles é igual a $V K T_{f, v, t}$.
} 


\subsection{USEPA MOVES}

A exceção da Califórnia ${ }^{90}$, nos Estados Unidos a avaliação das políticas regionais de controle de qualidade do $\operatorname{ar}^{91}$ é feita oficialmente por meio de uma ferramenta de inventário da USEPA. Até recentemente, a ferramenta empregada era um programa denominado MOBILE $^{92}$.

O MOBILE baseia-se nas médias dos resultados observados em ensaios dinamométricos segundo ciclos predefinidos, para cada classe de veículo, à semelhança do que está sendo praticado no Brasil, sobre os quais são aplicados fatores de correção que visam levar em conta os efeitos do desgaste do veículo, temperatura, umidade e programas de inspeção veicular. Para considerar a significativa influência da condição de uso é utilizada a velocidade média do veículo.

No entanto, um comitê do NRC avaliou e julgou o MOBILE muito impreciso para reproduzir as emissões dos veículos em condições reais de uso, o que, consequentemente, poderia levar a implantação de políticas ineficazes com possíveis impactos negativos no meio ambiente, na saúde e na aplicação dos recursos públicos (NRC, 2000).

Em função disso, a partir de 2001, a USEPA iniciou o desenvolvimento de um novo programa para modelagem de emissões veiculares, denominado "Motor Vehicle Emission Simulator" ou MOVES $^{93}$. A partir de 2010, a versão MOVES2010 ${ }^{94}$ começou a substituir oficialmente o MOBILE. Segundo a USEPA, o MOVES consolida todo seu conhecimento relativo à emissão de fontes móveis e sua extensa base de dados com milhões de resultados experimentais. Tratase de um programa de domínio público, desenvolvido com linguagens de programação também de domínio público (MySQL e Java). Sua interface é amigável, no entanto, por ser escalável segundo diferentes critérios que serão explicitados adiante, seu uso exige algum treinamento. A favor da disseminação de uso tem-se sua ampla documentação, a possibilidade da introdução de dados regionais e do suporte dessa agência.

\footnotetext{
90 Na California, o "Air Resources Board" (CARB) utiliza o programa de modelagem "Emission Factors" (EMFAC), atualmente em sua versão EMFAC2007. Sua concepção é semelhante a do MOBILE.

${ }^{91}$ Regulamentados por meio dos "State Implementation Plans" (SIPs) e "Transportation Conformity".

92 A última versão desse programa é o MOBILE 6.2.

93 Também se encontram referências utilizando a denominação "Multi-scale Motor Vehicle and Equipment Emission System".

${ }^{94}$ Preliminarmente foram lançadas as versões: 2004; HVI (2007); 2009.
} 
O MOVES permite o cômputo das massas emitidas de GEE $\left(\mathrm{CO}_{2}, \mathrm{CH}_{4}\right.$ e $\left.\mathrm{N}_{2} \mathrm{O}\right)$ e de emissões tóxicas regulamentadas ( $\mathrm{CO}, \mathrm{HC}, \mathrm{HCNM}, \mathrm{COV}, \mathrm{NO}_{\mathrm{X}}, \mathrm{NH}_{3}, \mathrm{SO}_{2}, \mathrm{MP}_{10}$ e $\mathrm{MP}_{2,5}$ ) e não regulamentadas (benzeno, etanol, MTBE, naftaleno, butadieno, formaldeído, acetaldeído e acroleína), e ainda do que eles denominam "emissão de energia", na verdade, os consumos de combustíveis total, fóssil e de petróleo em função do uso dos veículos (“do tanque à roda”).

As fontes e processos considerados incluem: gases de escapamento; gases do cárter; emissões evaporativas que ocorrem no veículo e na distribuição dos combustíveis via permeação, ventilação de vapores e vazamentos; e material particulado gerado pelos pneus e freios. Eles pretendem ainda implantar nessa ferramenta o cômputo dos GEE que ocorrem na produção dos combustíveis ("do poço ao tanque") e na manufatura e sucateamento dos veículos, por meio da utilização do modelo GREET ${ }^{95}$ do "Argonne National Laboratory" (ANL) do USDOE.

Inicialmente, para melhor representá-las, as emissões dos gases de escapamento foram divididas em três processos: partida, rodando e marcha lenta prolongada ("extended idle"). Está última para refletir a condição que tipicamente ocorre em veículos que, mesmo parados, necessitam manter o motor operando (ex. ônibus e caminhões frigoríficos).

As maiores emissões que ocorrem na partida variam em função do tempo parado. E para permitir uma melhor reprodução das diferentes condições de uso dos veículos rodando, no lugar de fatores de emissão médios dos ciclos de condução, tipicamente obtidos nos procedimentos de homologação, os resultados de emissões foram segmentados em doze classes ("bins") de potência específica do veículo (VSP, sigla em inglês) e de três classes de velocidade, contidas pelos limites de 40 e $80 \mathrm{~km} / \mathrm{h}(25$ e $50 \mathrm{~m} / \mathrm{h})$. VSP é a razão entre a potência instantânea gerada pelo motor do veículo e sua massa, usualmente expressa em $\mathrm{kW} /$ ton, que junto com a velocidade, mostrou uma boa correlação com os níveis de emissões. Segundo estudo do ANL (KWON; ROUSSEAU; SHARER, 2007), esse critério é capaz de predizer o consumo dos veículos, exceto híbridos ${ }^{96}$, com incerteza inferior a $5 \%$, apesar de sugerirem a inclusão de duas novas classes ("bins") para melhor representar a condução mais agressiva.

Sua interface permite a seleção de diferentes níveis de agregação dos resultados, segundo critérios:

\footnotetext{
${ }^{95}$ Disponível em http://greet.es.anl.gov/

${ }^{96}$ Para "plug-in hybrids" (PHEV) a incerteza chegou a ser superior a $20 \%$.
} 
a) Geográficos

É possível calcular as emissões nacionais; estaduais; municipais ("county"); regionais ("zone") e para até cinco tipos de via: com ou sem acesso restrito, urbana, rural e fora de estrada ("offhighway"), existentes nos Estados Unidos. Estão ainda sendo implantados os níveis: vias arteriais (“link”) e conjuntos (“grid”), agregando itens dos níveis geográficos mais detalhados. A cada um desses níveis estão previamente associados, por exemplo, o clima, tipo de via (ex. porcentagem com rampas), histórico do combustível distribuído, condição de uso (ex. tempo parado), etc., que ocorrem no local.

b) Temporais

É possível calcular as emissões horárias ao longo de um dia, de um dia da semana ou do final de semana, semanais, mensais e ao longo dos anos. Este último é o único realmente vinculado ao calendário.

c) Tipos de fontes móveis

Inicialmente válida para o modal rodoviário, as emissões dos veículos são segmentadas por classes (ex. auto, ônibus, caminhão de lixo...), ano-modelo, idade, combustíveis e tecnologias, tanto no que diz respeito aos sistemas de controle de emissões ("regulatory class"), quanto às novas tecnologias de tração (ex. híbridos). À estas estão associadas suas características típicas, como peso, tamanho e tecnologia do motor, uso e condição de manutenção de sistemas de ar condicionado, etc. É intenção da USEPA ainda implantar no MOVES o cômputo das emissões de outros modais.

d) Características dos combustíveis

São ainda considerados: o tipo e subtipo do combustível (ex. gasolina, gasolina reformulada, diesel, etc.); suas formulações quanto a propriedades específicas (ex. teor de aromáticos e de enxofre), e sua distribuição ao longo do tempo e do espaço.

e) Frota, isto é, sua composição, inclusive em função do tempo, região e clima.

f) Condição de uso

Como já antecipado, o programa busca considerar os diversos aspectos associados à condição de uso que influenciam fortemente o consumo e as emissões, tais como: clima; presença de rampas; condição das vias; velocidades médias (tráfego); quilometragem acumulada; tempo parado ("soaking"); e distribuição de viagens em função do tempo (ao longo de um dia e tipo de dia da semana) e do tipo de via. 
g) Programas de inspeção veicular

Ao contrário do que ocorre no Brasil, onde o governo federal estabeleceu um modelo único para o programa de inspeção veicular $(\mathrm{I} / \mathrm{M})$, nos Estados Unidos, devido à liberdade dos estados e ao longo histórico evolutivo, esses programas utilizam diferentes técnicas de inspeção, limites e periodicidades.

Entretanto, esses programas, configurados localmente, constituem uma das importantes ferramentas dos governos locais para o cumprimento dos requerimentos do governo federal estadunidense para o combate da poluição atmosférica.

Consequentemente, o potencial e o alcance efetivo do modelo de programa I/M empregado para a redução das emissões são cuidadosamente avaliados por meio de parâmetros como "emission reduction fraction", "I/M coverage fraction" e "compliance factor". A eficácia de um programa é sintetizada por meio de um parâmetro definido como "IMfactor", que mede o desempenho do programa adotado localmente em relação a um programa arbitrariamente escolhido.

A operação do modelo do MOVES para os veículos rodando pode ser representada pelo esquema apresentado na Ilustração 3.1.

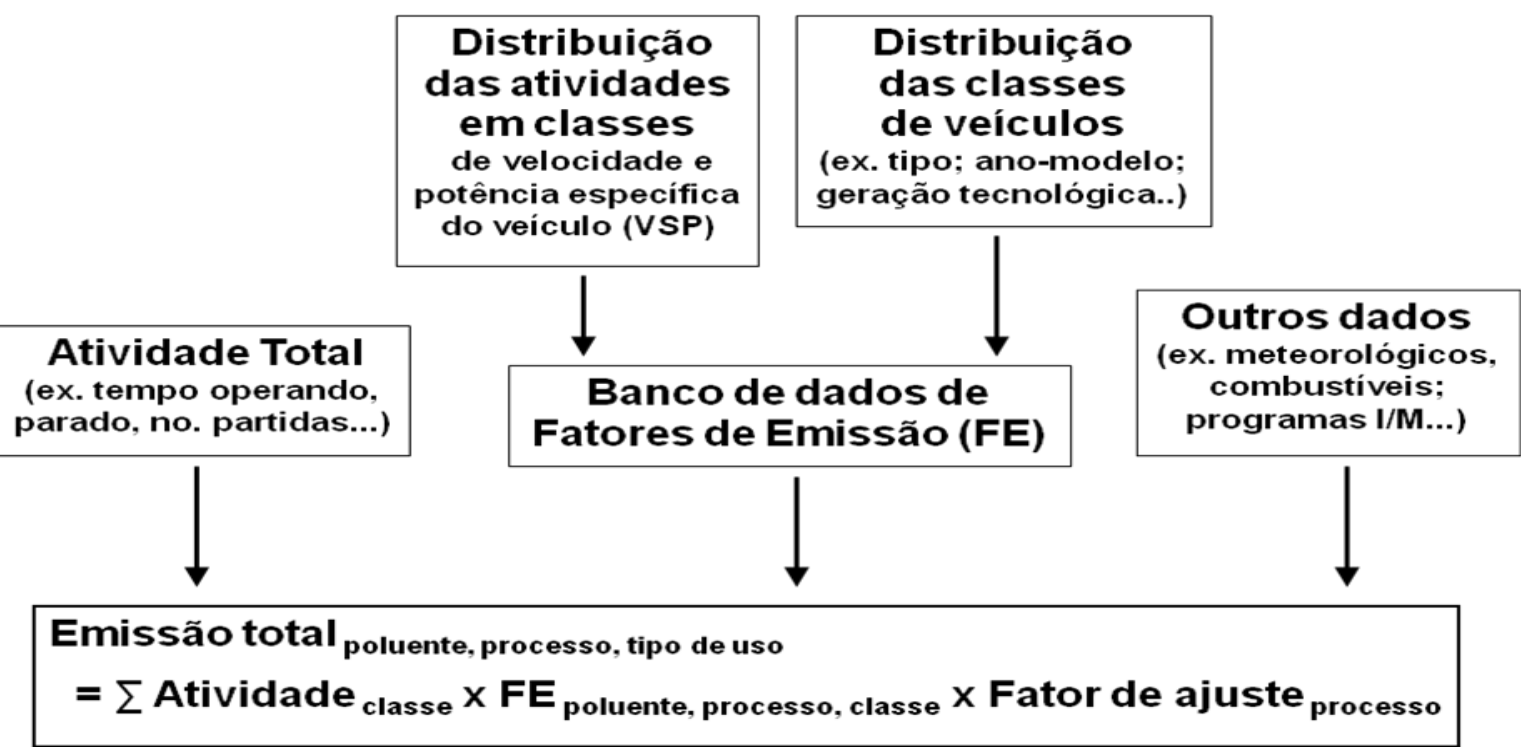

\section{Ilustração 3.1 -.Esquema de operação do MOVES.}

Fonte: Elaborado pelo autor com base em dados do MOVES. 
Resumidamente, o MOVES é um "software" de domínio público, modular, com interface amigável, com diferentes opções de entrada e saídas, que permite inventariar e avaliar sistemas de transportes quanto ao consumo e às emissões veiculares de GEE e de gases tóxicos em diferentes escalas geográficas ${ }^{97}$ e temporais (hora, dia e ano), incorporando aspectos como composição da frota, condições de trânsito, propriedades do combustível e dados meteorológicos. Para melhor simular as emissões dos veículos em condições de uso, os fatores de emissões, na escala desejada, são estimados com base nas emissões observadas nos veículos, agrupados em subcategorias, para diferentes aspectos como peso do veículo, faixa de potência, tecnologia, categoria legal de emissões, etc. Para tanto, o MOVES contém uma extensa base de dados, levantados da realidade norte-americana.

\subsection{Uma sinopse sobre os modelos de inventários}

Um resumo das principais características desses modelos é apresentado na Tabela 3.4.

Tabela 3.4 - "EMEP/EEA guidebook 2009 - Tier 3" - Variáveis intermediárias

\begin{tabular}{|c|c|c|c|}
\hline Modelo & $\begin{array}{c}\text { Básico } \\
\text { ("top-down") }\end{array}$ & $\begin{array}{l}\text { Intermediário } \\
\text { (“'botton-up”) }\end{array}$ & $\begin{array}{l}\text { Avançado } \\
\text { (escalável) }\end{array}$ \\
\hline $\begin{array}{c}\text { Guia IPCC } 2006 \\
\text { GEE }\end{array}$ & $\begin{array}{c}\mathrm{CO}_{2} \text { Tier } 1 \text { e } 2 \text { : } \\
\text { f(consumo, (ureia)) } \\
\quad \mathrm{CH}_{4} \text { e } \mathrm{N}_{2} 0 \\
\text { Tier 1: f(consumo) } \\
\text { Tier 2: f(consumo, } \\
\text { classe, tecnologia) }\end{array}$ & $\begin{array}{l}\text { Tier } 3\left(\mathrm{CH}_{4} \text { e } \mathrm{N}_{2} 0\right) \text { : } \\
\text { f(consumo, classe, } \\
\text { tecn., (operação)) } \\
\text { + emissões a frio } \\
\text { discretizadas }\end{array}$ & \\
\hline $\begin{array}{c}2^{\circ} \text { Inventário Brasileiro } \\
\text { de GEE (1990 a 2005) }\end{array}$ & $\begin{array}{c}\mathrm{CO}_{2}, \mathrm{CH}_{4} \text { e } \mathrm{N}_{2} 0: \\
\mathrm{f}(\text { consumo, classe })\end{array}$ & & \\
\hline $\begin{array}{c}\text { Guia EMEP/EEA } 2009 \\
\text { (GEE e tóxicos) }\end{array}$ & $\begin{array}{c}\text { Tier 1: } \\
\mathrm{f}(\text { consumo, classe })\end{array}$ & $\begin{array}{c}\text { Tier 2: } \\
\text { f(consumo, classe, } \\
\text { tecnologia })\end{array}$ & $\begin{array}{c}\text { Tier 3: } \\
\text { f(consumo, classe, } \\
\text { tecnologia, condição de } \\
\text { uso, clima, etc. })\end{array}$ \\
\hline $\begin{array}{l}1^{\circ} \text { Inventário Nacional } \\
\text { de Emissões Atmosf. }\end{array}$ & & $\begin{array}{l}\text { tóxicos regulados, } \\
\qquad \mathrm{CO}_{2}, \mathrm{CH}_{4}\end{array}$ & \\
\hline $\begin{array}{l}\text { MOVES } 2010 \text { da USEPA } \\
\text { (GEE e tóxicos) }\end{array}$ & & & $\begin{array}{l}\text { programa baseado em } \\
\text { extenso banco de dados, } \\
\text { com emissões calculadas } \\
\text { com base em VSP }\end{array}$ \\
\hline
\end{tabular}

Fonte: Elaborado pelo autor, com base nas informações deste capítulo.

${ }^{97}$ Denominadas pela EPA de macro, meso ou micro escalas. 
Ferramentas como o "EMEP/EEA Guidebook 2009" e o MOVES da USEPA reúnem grande conhecimento da engenharia automotiva e experiência no desenvolvimento de inventários. Essas ferramentas possibilitam avaliar e prognosticar mais detalhada e precisamente as tendências evolutivas de novos combustíveis e tecnologias e de políticas públicas associadas à frota e ao transporte rodoviários. Entretanto, a abrangência e flexibilidade dessas ferramentas derivam da grande complexidade de suas bases de dados, fato que dificulta sua aplicação em outros contextos que não aqueles para o qual foram desenvolvidos.

É preciso lembrar que a conjuntura brasileira apresenta diferenças significativas em relação à realidade europeia e norte-americana, no que tange à frota, aos combustíveis e à condição de uso dos veículos. Nossos veículos são tecnologicamente alguns anos atrasados em relação aos dessas regiões, em função, sobretudo, da defasagem para implantar basicamente as mesmas legislações delas. A frota brasileira é predominantemente constituída por modelos mais simples e possui parcela significativa de automóveis com motor de 1 litro e de veículos leves "flex". Também utilizamos combustíveis diferenciados: gasolina $\mathrm{C}$, etanol hidratado e biodiesel $(B 5)^{98}$. Os congestionamentos em nossos grandes centros são mais agudos. E em função desses congestionamentos e de nossa realidade econômica, a frota de motociclos vem crescendo aceleradamente e apresenta uso mais intensivo, como ocorre com a frota dos "motoboys". As estradas brasileiras são, em geral, pior mantidas. Além disso, há poucos estudos ou mecanismos que permitam inferir qual é o real estado de manutenção da frota em circulação ${ }^{99}$.

O risco de se adotar modelos não representativos da realidade brasileira é oficialmente reconhecido no "Primeiro Inventário Brasileiro de Emissões Antrópicas de Gases de Efeito Estufa", onde está declarado...

Por sua própria origem, a metodologia do IPCC adotada pela Convenção tem, como referência, pesquisas realizadas e metodologias elaboradas por especialistas de países desenvolvidos... Portanto, os fatores de emissão ou até mesmo a própria metodologia devem ser analisados com a devida cautela, uma vez que não refletem, necessariamente, as realidades nacionais. Em muitos casos, não há pesquisa no Brasil que permita avaliar os valores apresentados ou a própria metodologia proposta. Onde existem pesquisas, foram encontrados, em alguns casos, valores significativamente discrepantes.

\footnotetext{
${ }^{98}$ Essa diferença pode diminuir com a ampliação da participação dos combustíveis renováveis nessas regiões.

${ }^{99}$ Representada nos modelos pelos fatores de deterioração que a ela se aplicam.
} 
As maiores restrições para o adequado desenvolvimento dos modelos nacionais são a dificuldade para se ter acesso a dados oficiais, mesmo os mais básicos, como aqueles que permitiriam melhor caracterizar a constituição de nossas frotas, e a falta de levantamentos estatísticos e experimentais que melhor revelem as condições de uso dos veículos no Brasil. Essa fragilidade é tanto apontada no "Primeiro Inventário Brasileiro" do MCT...

No Brasil, a busca e coleta de informação não são adequadas por causa do custo de obtenção e armazenamento de dados e há pouca preocupação institucional com a organização ou fornecimento de informação, principalmente em nível local. Há, ainda, carência de legislação que obrigue as empresas a fornecer informações, em especial no que diz respeito às emissões de gases de efeito estufa. Por outro lado, muitas vezes, medições não se justificam para o inventário de emissões de gases de efeito estufa por si só, devido ao custo relativamente alto da medição, quando comparado a qualquer melhoria da precisão da estimativa.

Como no "1 Inventário Nacional de Emissões Atmosféricas por Veículos Automotores Rodoviários" do MMA, onde consta em suas recomendações finais...

\begin{abstract}
...Devido à grande diversidade de tipos, idades e condições operacionais dos veículos, os dados básicos utilizados neste Inventário Nacional de Emissões fatores de emissão, a intensidade de uso, a composição e o tamanho da frota, podem apresentar um elevado grau de incerteza. Essas incertezas refletem-se nos cálculos das emissões do Inventário.

...Para outras aplicações, em especial às relacionadas a ações locais ou à modelagem da qualidade do ar e, indiretamente, à avaliação de efeitos à saúde, será necessária, além da melhoria da qualidade da informação disponivel, a elaboração de inventários com resoluções espaciais, e mesmo temporais, mais elevadas. A elaboração de inventários regionais e locais exigirá, portanto, esforços adicionais na coleta e sistematização de dados em um detalhamento maior.
\end{abstract}

Naturalmente, na falta de informação melhor, é plausível utilizar alguns dos dados contidos nas ferramentas estrangeiras, tais como fatores de emissão de veículos similares aos nacionais. Porém antes de utilizá-los é primeiro necessário avaliar criteriosamente a coerência desses dados, tarefa que é tanto mais difícil quanto mais sofisticado for o modelo.

As diversas entidades que trabalham nesse campo no Brasil vêm buscando soluções para atuais limitações e estão conseguindo incorporar novas informações em seus modelos. As novas versões dos inventários oficiais que vêm sendo divulgadas, em geral, contêm avanços em relação às anteriores. Infelizmente para o país nem sempre esses dados são compartilhados, possivelmente porque são encarados como uma vantagem competitiva da entidade que os conseguiu. 
Entretanto, não podemos esquecer-nos da importância dessas ferramentas para subsidiar a elaboração das políticas públicas e dos alertas dados pela Agência Ambiental Europeia e pelo Conselho Nacional de Pesquisas estadunidense, descritos na introdução deste trabalho, quanto ao risco de que modelos imprecisos podem "levar à implantação de políticas ineficazes com possíveis impactos negativos no meio ambiente, na saúde e na aplicação dos recursos públicos".

Lembrando que a razoabilidade do modelo depende do objetivo ao qual ele se destina e considerando que o propósito deste trabalho é o de projetar o impacto que as principais metas e tendências evolutivas da frota rodoviária nacional causarão no consumo de combustíveis e nas emissões veiculares, o próximo passo consistiu em avaliar e adequar os modelos disponíveis focando esse objetivo. Face às restrições existentes para a obtenção de dados adicionais, esta tarefa começou pela avaliação dos atuais modelos oficiais nacionais. 


\section{DESENVOLVIMENTO DO TRABALHO}

O desenvolvimento da ferramenta de inventário e prognóstico do consumo e das emissões veiculares foi realizado por meio das seguintes etapas que serão a seguir detalhadas:

- Avaliação dos modelos de inventário existentes.

- Aperfeiçoamento do modelo "bottom-up".

- Desenvolvimento dos modelos econométricos.

- Desenvolvimento do modelo híbrido.

- Premissas adotadas para a realização das projeções.

- Análise de sensibilidade.

- Aplicação dos modelos desenvolvidos para a projeção de alguns cenários.

\subsection{Avaliação dos modelos de inventário existentes}

Restritos pelos dados disponíveis, os inventários nacionais oficiais, a exceção do "Segundo Inventário de GEE" do MCT, utilizam modelos expressos por equacionamento semelhante ao “Tier 2" do "EMEP/EEA air pollutant emission inventory guidebook 2009”. Isto é:

$$
\text { Emiss ão }_{p}=\sum_{f, v, t}\left[N_{f, v, t} \times \text { KmAnual }_{f, v, t} \times F E_{p, f, v, t}\right]
$$

onde Emissão $o_{p}$ é a emissão do poluente $p$, em g.

$N_{f, v, t} \quad$ é o número de veículos que rodam com o combustível $f$, da classe de veículo $v$, com tecnologia de controle de emissões $t$.

$\mathrm{KmAnual}_{f, v, t}$ é quilometragem média anual por veículo, daqueles que rodam com o combustível $f$, da classe de veículo $v$, com tecnologia de controle de emissões $t$.

$F E_{p, f, v, t} \quad$ é o fator de emissão do poluente $p$, em g/veículo.km, relativo ao combustível $f$, da classe de veículo $v$, com tecnologia de controle de emissões $t$.

Convém lembrar que: 


$$
\sum_{f, v, t}\left[N_{f, v, t} \times \text { KmAnual }_{f, v, t}\right]=V K T_{f, v, t}
$$

onde $V K T_{f, v, t}$

é a quilometragem anual acumulada, com o combustível $f$, da classe de veículo $v$, com tecnologia de controle de emissões $t$.

Dado que as fontes oficiais brasileiras não fornecem dados robustos sobre a composição da frota ${ }^{100}$, para obter um quadro mais realista, ela, ou seja $N_{f, v, t}$, é estimada a partir do número de veículos, nacionais e importados, comercializados ou licenciados no Brasil anualmente, sobre o qual se aplica uma taxa de sobrevivência. Esta taxa expressa, em relação ao total de veículos novos licenciados em um determinado ano, que parcela continua circulando nos anos subsequentes. Tanto a taxa de sobrevivência do "1 Inventário Nacional" do MMA, como do recém-divulgado relatório da CETESB "Emissões veiculares no estado de São Paulo 2012" (CETESB 2013) se baseiam nas curvas de sucateamento utilizadas pelo Serviço de Planejamento da PETROBRAS, calibradas pelos dados da PNAD de 1988. Além deste, a CETESB também utiliza um fator de segregação para veículos pesados e um fator de correção para compatibilizar o resultado do modelo com a frota divulgada pelo DETRAN de São Paulo.

Alternativamente se utilizam funções logísticas que podem ser ajustadas de forma que o modelo forneça uma frota em um determinado ano semelhante a alguma estimativa oficial existente, que foi o procedimento empregado no "Segundo Inventário de GEE" para a composição da frota realizada pelo DENATRAN em 1997.

Porém, como mostrado na Ilustração 4.1, a exceção da curva dos motociclos, essas curvas diferem muito das correspondentes utilizadas pelo MOVES (USEPA 2010), desenvolvidas com base em levantamento estatístico dos registros dos veículos, o que sugere que as curvas nacionais precisam ser no mínimo reavaliadas.

Outro aspecto importante a ser considerado é a intensidade de uso dos veículos, isto é, a quilometragem média percorrida anualmente por cada tipo de veículo. Essa intensidade decresce em função da idade do veículo, devido à maior necessidade de manutenção e à desvalorização do veículo e, por conseguinte, o menor poder aquisitivo de seus proprietários ou

\footnotetext{
100 Por não ser uma prática comum dar-se baixa dos veículos sucateados no RENAVAM, os dados do DENATRAN tendem a serem superiores aos reais, enquanto que, devido uma parcela não desprezível da frota circular sem estar devidamente licenciada, os dados do DETRAN tendem a ser inferiores aos reais. Destaque-se que veículos são sucateados não somente em função de acidentes, mas também por roubos e furtos, e quando o custo de manutenção se aproxima do valor do veículo.
} 
a menor atratividade comercial. Para expressar essa realidade, utiliza-se uma taxa de acumulação de quilometragem (TAQ) ${ }^{101}$. O "1 Inventário" do MMA e o último inventário da CETESB assumiram que isso ocorra segundo as curvas apresentadas na Ilustração 4.2.
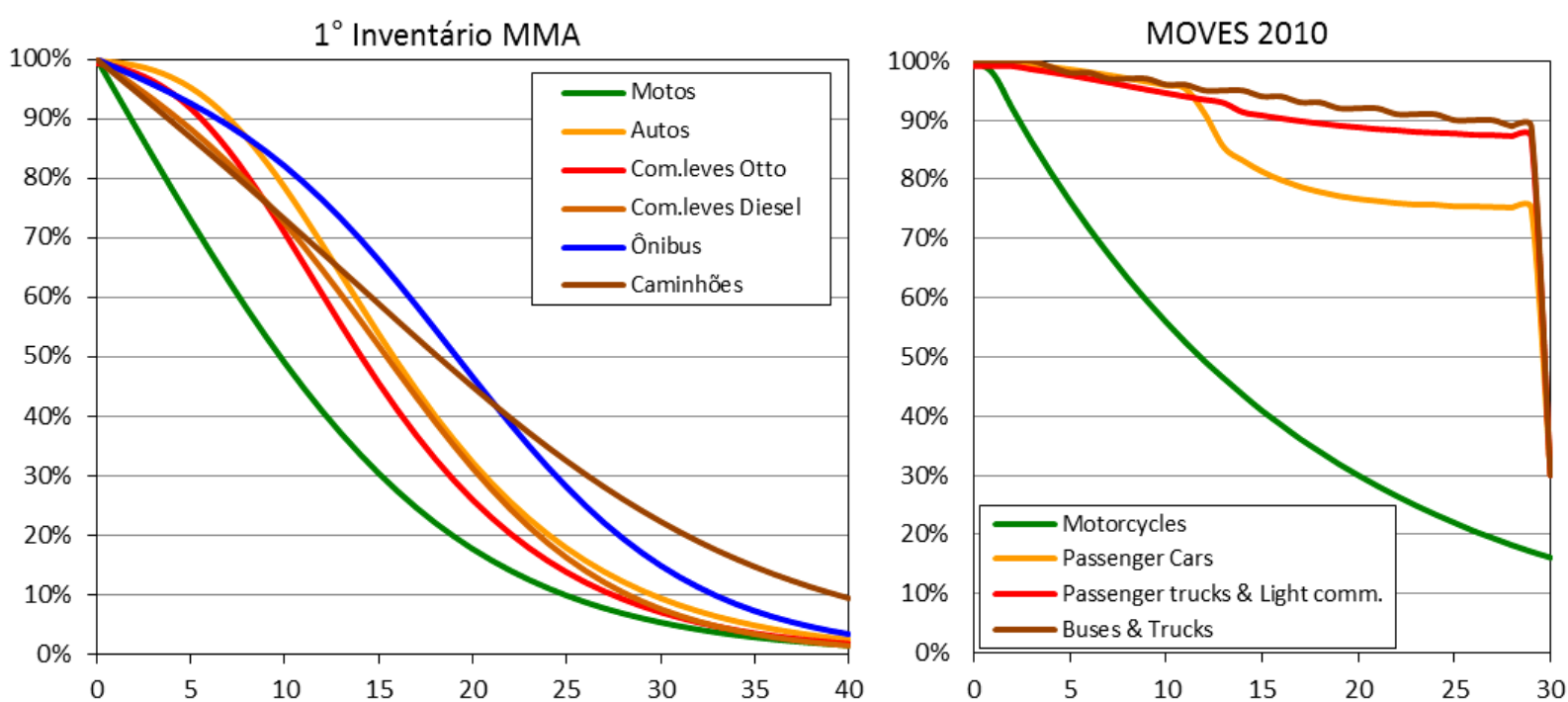

Ilustração 4.1- Taxas de sobrevivências do "1 Inventário" do MMA e do "MOVES 2010".

Fonte: Elaborado pelo autor com base em dados do "1º Inventário Nacional de Emissões Atmosféricas por Veículos Automotores Rodoviários" e do "MOVES2010 Highway Vehicle Population and Activity Data".
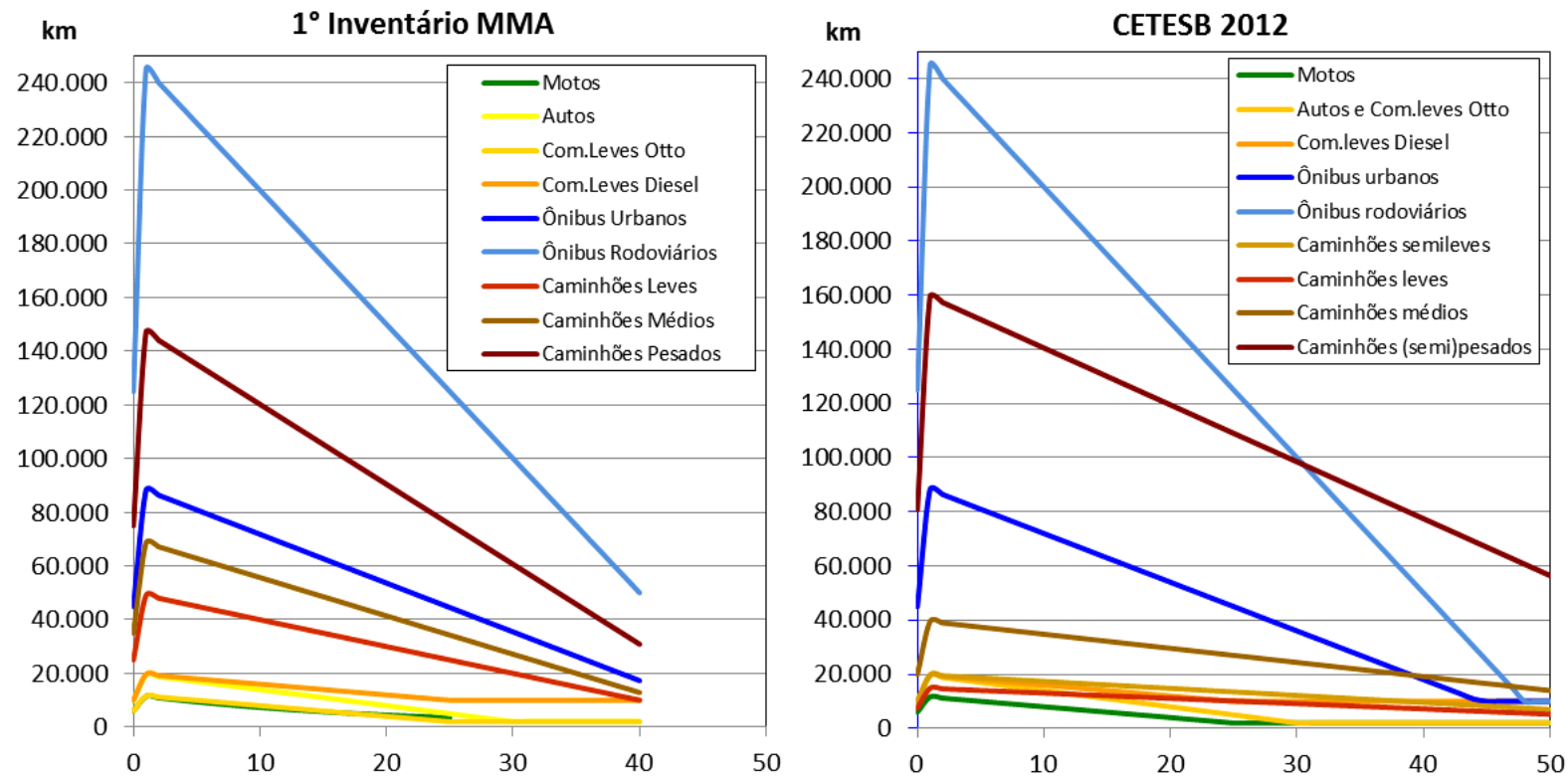

Nota: O aspecto "quebrado" dessas curvas é para levar em consideração que na média somente metade da frota percorrerá a quilometragem que ocorre no primeiro ano de vida dos veículos.

\section{Ilustração 4.2 - Taxa de acumulação de quilometragem ("intensidade de uso") do "10 Inventário" do MMA e do "Relatório 2012" da CETESB.}

Fonte: Elaborado pelo autor com base em dados do "10 Inventário" do MMA e do "Relatório 2012" da CETESB.

${ }^{101}$ Os inventários nacionais vêm denominando a essa taxa de "intensidade de uso", mas este autor julga que a denominação taxa de acumulação de quilometragem (TAQ) é mais precisa para expressar o conceito nela contido. 
Apesar das pequenas diferenças, sobretudo, na divisão e valores aplicados aos caminhões, a CETESB vinha usando as mesmas curvas do MMA, o que sugere que essas são as novas curvas que serão também utilizadas pelo MMA.

Alternativamente, o MOVES utiliza uma taxa de acumulação de quilometragem relativa (TAQR), mostrada na Ilustração 4.3, que multiplicada pela quilometragem acumulada no primeiro ano resulta na TAQ anterior. Apesar das diferenças dos critérios, confrontado o aspecto dessas curvas com a intensidade de uso dos inventários nacionais mais uma vez observa-se diferença significativa. Ao contrário das taxas de sobrevivência, que podem ser ajustadas por meio de levantamentos que indiquem a composição da frota em um determinado momento, não há uma referência direta que permita ajustar as curvas da TAQ ou da TAQR.

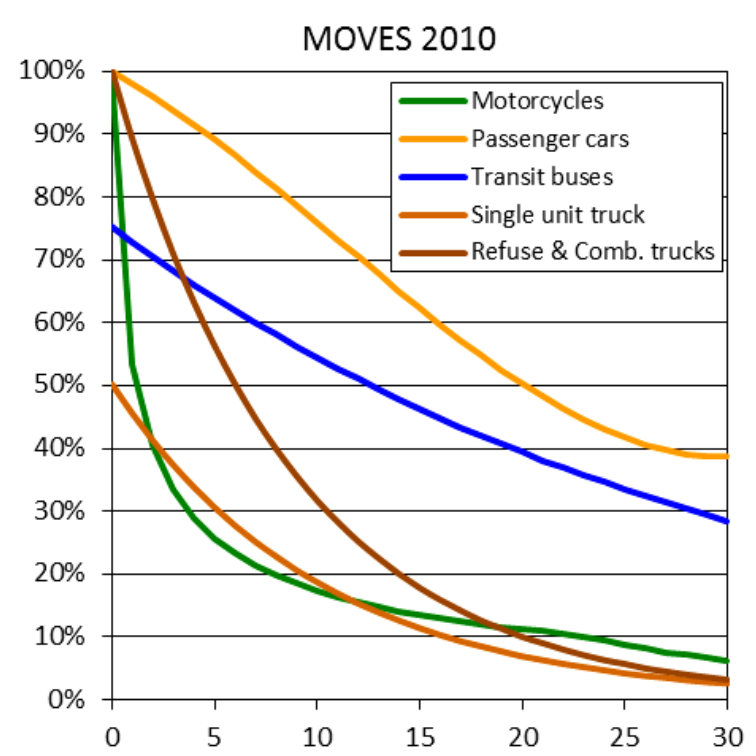

Ilustração 4.3 - Taxa de acumulação de quilometragem relativa do "MOVES 2010".

Fonte: Elaborado pelo autor com base no "MOVES2010 Highway Vehicle Population and Activity Data".

Outra expressiva fonte de incerteza, sobretudo no caso dos veículos pesados, é o consumo médio dos veículos em uso. Para motociclos, automóveis e comerciais leves ciclo Otto, os inventários oficiais utilizam valores levantados em laboratório, segundo procedimento padronizado que simula condição de uso urbano. Para os motociclos há dados divulgados somente de 2011 e 2012. Os consumos reais são, em geral, um pouco superiores aos valores observados em laboratório.

Já os procedimentos de ensaio regulamentados para veículos pesados são realizados somente em seus motores e a grandeza associada resultante usualmente divulgada é o consumo específico mínimo, expresso em g/kWh. Este consumo foi empregado, pelo menos em parte, 
para a obtenção das estimativas realizadas pela ANFAVEA e pela Petrobras, utilizadas nos inventários oficiais, apresentadas na Tabela 4.1.

Tabela 4.1 - Valores médios de consumo de veículos com motores ciclo Diesel.

\begin{tabular}{cc}
\hline Categoria & Eficiência $[\mathbf{k m} / \mathbf{l}]$ \\
\hline Comerciais leves & 9,09 \\
Caminhões leves & 7,61 \\
Caminhões médios & 5,56 \\
Caminhões pesados & 3,17 \\
Ônibus urbanos & 2,30 \\
Ônibus rodoviários & 3,03 \\
\hline
\end{tabular}

Fonte: Tabela 14, p. 39 do Relatório final do "1º Inventário Nacional" do MMA e Anexo J, p. 54 do Relatório "Emissões Veiculares no Estado de São Paulo 2011" da CETESB.

Porém, na prática, intensidade de uso e consumos, principalmente dos caminhões, podem ser significativamente diferentes dos valores adotados. A título de exemplo, durante a discussão dos modelos oficiais, o Serviço de Pós-Venda da Mercedes-Benz informou que o consumo de caminhões pesados varia de 1,5 a 2,5 km/l, cujo valor médio implicaria em uma diferença de consumo de cerca de $37 \%$ em relação aos valores da Tabela 4.1.

Além disso, é fácil intuir que rigorosamente a taxa de sobrevivência, a intensidade de uso e o consumo dos veículos variam tanto localmente como ao longo do tempo em função, por exemplo, da condição do trânsito e das vias; do índice de acidentes e de roubos; dos veículos ficarem cada vez mais confiáveis; da composição da frota; e da intensidade de uso depender do momento econômico. Rigorosamente, é necessário realizar levantamentos experimentais e estatísticos na frota em uso para obter valores estatisticamente robustos desses parâmetros.

Como a multiplicação desses fatores resulta no consumo de combustíveis da frota, inclusive para compensar a fragilidade dos dados, os inventários de emissões veiculares oficiais invariavelmente utilizam consumo total de combustíveis na região e período considerado para aferir seus modelos "bottom-up". No caso dos modelos "top-down”, usados para calcular a emissão de $\mathrm{CO}_{2}$, este é o princípio do modelo e a única dificuldade está em prognosticar adequadamente o consumo futuro. Nos modelos "bottom-up", necessários para inventariar as demais emissões, a razão do consumo observado sobre o estimado é utilizado como um fator de ajuste da intensidade de uso. Este ajuste é pertinente, mas a aderência do modelo à realidade também pode afetar seus resultados. Este procedimento foi utilizado tanto no " $1^{\circ}$ Inventário Nacional de Emissões Atmosféricas por Veículos Automotores Rodoviários", como no recente 
relatório da CETESB, conforme descrito em seu item 2.9. As diferenças entre os consumos de gasolina, etanol e óleo diesel observados e estimados por meio da adoção das premissas anteriores do " $1{ }^{\circ}$ Inventário Nacional” do MMA são apresentadas na Ilustração 4.4.
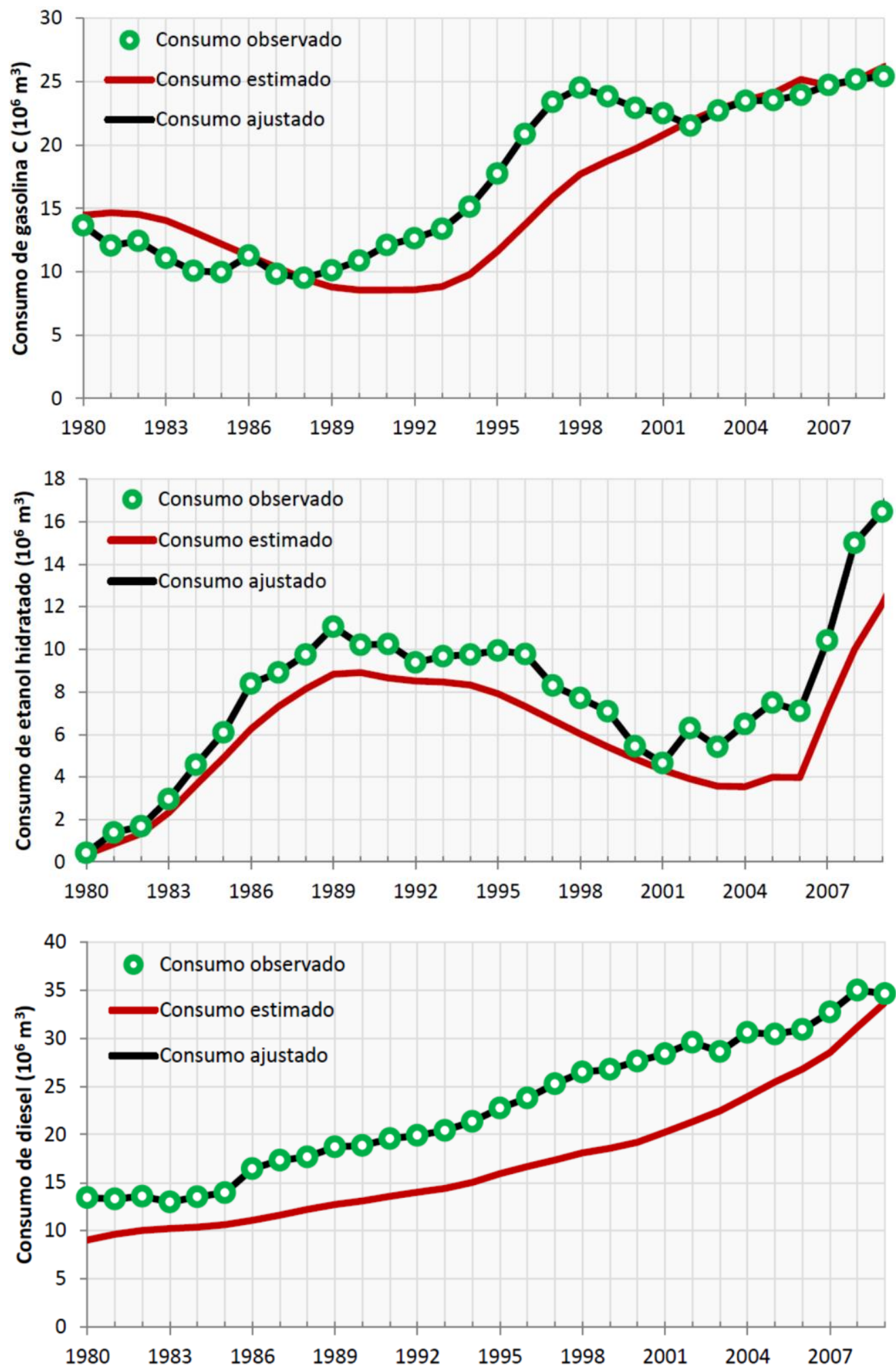

Ilustração 4.4 - Evolução dos consumos observados e estimados no "1" Inventário Nacional".

Fonte: Gráfico 16, p. 49 do Relatório final do “1 Inventário Nacional” do MMA. 
Expressas em consumo energético, essas diferenças em 1998 chegam a ser da ordem de $40 \%$ no caso dos combustíveis Otto e 50\% no caso do Diesel. Porém, mais significativo para o propósito deste trabalho, é verificar que dificilmente seria possível utilizar a projeção desse modelo para predizer o consumo em anos futuros. Infelizmente, as curvas equivalentes do recente inventário da CETESB não foram divulgadas.

Em função dessa realidade, concluiu-se que seria necessário adotar uma abordagem diferenciada para realizar as projeções. Em função das informações disponíveis, decidiu-se trabalhar com dois contextos: o brasileiro e o paulista.

\subsection{Aperfeiçoamento do modelo "bottom-up"}

Devido a trabalhos similares, o autor já havia desenvolvido ferramenta computacional baseada nos mesmos princípios e fontes de dados dos inventários oficiais, a qual foi revista e atualizada. Nessa revisão mais uma vez buscaram-se dados de fontes confiáveis que melhor reproduzissem a realidade. Dos inventários oficiais foram mantidas todas as informações baseadas em levantamentos experimentais e estatísticos, tais como, o consumo médio de automóveis e fatores de emissão médios (CETESB 2013). Mas em muitos casos foi necessário utilizar estimativas com base em fragmentos de informações.

Para diferenciar características e condições de uso e, consequentemente, emissões e possibilidades de atuação, os veículos foram inicialmente segregados em cinco classes: motociclos, automóveis, comerciais leves, ônibus e caminhões. As três primeiras foram ainda segmentadas segundo a opção de combustível utilizado. Isto é, motociclos a gasolina e "flex"; e automóveis e comerciais leves a gasolina, etanol, "flex", diesel e GNV. Apesar de uma participação inexpressiva em anos anteriores, foi introduzido o segmento "automóveis a diesel" com o propósito de possibilitar a avaliação uma eventual liberação do uso do biodiesel para essa classe de veículos. Os ônibus foram segmentados em micro-ônibus, ônibus urbanos convencionais e ônibus rodoviários, e os caminhões em semileves, leves, médios, semipesados e pesados.

Para compor a frota, além do número de veículos comercializados ou licenciados regularmente divulgados pela ABRACICLO e ANFAVEA, foi necessário recorrer a outras fontes. A segmentação de motociclos à gasolina ou "flex" foi obtida por meio da totalização dos números de modelos "flex" vendidos, divulgados somente de forma segregada pela ABRACICLO. O número estimado de veículos convertidos para GNV em São Paulo foi fornecido pela 
COMGAS. A segmentação dos caminhões empregada é aquela atualmente atualizada pela ANFAVEA. Porém, como anteriormente a 2001 essa entidade utilizava outro critério, referente a esse período, utilizou-se uma redivisão gentilmente cedida e estimada pelo IEMA com base em dados da ANFAVEA, da ADK Automotive e do DNIT. A segmentação dos ônibus foi feita com base em dados da Associação Nacional dos Fabricantes de Ônibus (FABUS) e, em parte, nessa redivisão do IEMA. Os números levantados e as estimativas realizadas são apresentados na planilha "Novos" de São Paulo, por esta conter dados adicionais em relação à planilha correspondente do Brasil. Esta e demais planilhas a seguir referenciadas estão reproduzidas nos correspondentes arquivos ".png” do CD em anexo ${ }^{102}$.

Lembrando que as únicas referências consistentes disponíveis para o ajuste desse modelo "bottom-up" são os consumos de combustíveis totalizados observados no país, para fazer frente às significativas incertezas das estimativas que precisam ser empregadas, para auxiliar esse ajuste desenvolvemos o procedimento a seguir descrito.

Todas as referências, dados e cálculos foram integrados na mesma ferramenta, resultando em uma extensa pasta de trabalho ${ }^{103}$ do padrão MS Excel. Todos os cálculos realizados em uma planilha são referenciados a sua fonte, de forma que a alteração de qualquer dado em qualquer ponto da pasta de trabalho altera o resultado final do modelo. Isso possibilita a fácil visualização do impacto que, na ausência de melhor informação, dados estimados causam nos resultados de consumo de combustíveis totalizados gerados pelo modelo.

Para facilitar esse ajuste, as curvas de taxa de sobrevivência e de taxa de acumulação de quilometragem foram parametrizadas por meio de funções de Weibull ${ }^{104}$, e todos os parâmetros que afetam mais expressivamente o consumo, isto é, os coeficientes dessas funções, a quilometragem rodada no primeiro ano e o consumo de cada classe veicular, foram agrupados e destacados com fontes vermelhas na planilha "Ajuste". Essa planilha contém ainda, como referência, os valores correspondentes empregados pelos modelos oficiais e os gráficos de evolução do consumo de combustíveis, calculados pelo modelo e observados.

\footnotetext{
${ }^{102}$ Por serem muito extensas, para que o leitor possa avaliá-las no conjunto, todas as planilhas utilizadas deste trabalho são apresentadas no formato gráfico “.PNG', que podem ser abertos por programas de visualização ou edição de imagens comuns da plataforma Microsoft Windows.

103 Arquivo contendo um conjunto de planilhas.

${ }^{104}$ Função desenvolvida por físico sueco de mesmo nome, para representar a distribuição probabilística do tempo de vida de equipamentos. Para maiores informações vide, por exemplo, <http://en.wikipedia.org/wiki/Weibull_ distribution>, acessado em 04/09/2013.
} 
Ao invés de adotar valores, ainda muitos incertos, para essas grandezas, por meio de um processo iterativo realizado nessa planilha, essas estimativas foram ajustadas, dentro de estreitas faixas $^{105}$, para que, sobretudo, o consumo totalizado resultante do modelo coincidisse tanto quanto possível com o consumo observado. Considerando que essas grandezas variam suavemente ao longo do tempo e do espaço, esse ajuste, focando anos recentes, é a melhor forma de reduzir a influência dessas incertezas na projeção. Apesar de esse processo envolver muitos parâmetros, esse procedimento permite que o resultado do modelo convirja rapidamente para sua referência. A seguir, esse processo é detalhado.

Com relação à taxa de sobrevivência, foi utilizada uma função de Weibull para cada uma das seguintes classes ou subclasses: motociclos, automóveis, comerciais leves Otto, comerciais leves Diesel, micro-ônibus, ônibus urbanos, ônibus rodoviários, e caminhões semileves, leves, médios, semipesados e pesados. Essas funções foram ajustadas de forma que o tamanho da frota de cada segmento coincidisse com a correspondente estimativa de frota circulante em 2007, realizada para o Banco Mundial (THE WORLD BANK, 2010) e apresentada nessa planilha.

As TAQs para cada uma das classes anteriores foram obtidas por meio de uma quilometragem acumulada no primeiro ano associada a uma TAQR, também parametrizada via função de Weibull. O ajuste desses parâmetros, também levou em consideração:

a) A quilometragem anual típica em seus primeiros anos de vida, de cada tipo de veículo, seja coerente com valores médios observados.

b) A quilometragem máxima percorrida de cada classe de veículo seja coerente com a expectativa de durabilidade desse veículo.

A exceção dos veículos pesados, as quilometragens anuais médias, ajustadas para obter o resultado desejado, são próximas daquelas empregadas nos inventários oficiais. As taxas de sobrevivência, TAQRs e TAQs resultantes, confrontadas às correspondentes de outras fontes, são apresentadas na planilha "PremissasV".

A exceção desse processo iterativo, o procedimento de cálculo a seguir descrito é similar ao dos modelos oficiais. O cálculo das quilometragens totais (VKT) de cada segmento em cada ano

\footnotetext{
${ }^{105}$ Por exemplo, a eficiência de um caminhão pesado variando na faixa entre $1,5 \mathrm{~km} / 1$, limite inferior sugerido pela Mercedes-Benz, e 3,17 km/l, utilizado nos inventários oficiais; ou ainda TAQs ajustadas de forma que a quilometragem total de um veículo seja compatível com as expectativas que se tem sobre sua durabilidade.
} 
são feitos com base no número de veículos novos licenciados e das taxas de sobrevivência e TAQs por meio das planilhas, uma para cada classe, "Motos", "Autos", "Com.Leves", "Onibus" e "Caminhoes". E a partir das VKTs, os consumos médios de cada classe, apresentados na planilha "PremissasH", e os fatores de emissão médios, apresentados na planilha "FEs", e considerando as especificidades de cada classe veicular, são também calculados nessas planilhas os consumos e as emissões totalizadas de cada segmento. As frotas e os consumos resultantes de cada segmento são totalizados nas planilhas, respectivamente, "Frota" e "Consumo".

Tomando como exemplo o consumo de combustível Otto no Brasil, que apresenta maiores variações que o Diesel, a adoção desse procedimento resultou no ajuste apresentado na Ilustração 4.5. Confrontando este resultado com o primeiro gráfico da Ilustração 4.4, observa-se que, apesar de expressas em diferentes unidades, as curvas são parecidas, o que sugere que o modelo oficial também utilizou as grandezas mais incertas para tentar conseguir esse ajuste, muito provavelmente a TAQ, nesse caso focando especificamente o consumo de gasolina C. Mas o resultado abaixo, ao contrário da modelo oficial, também contém os consumos de etanol e GNV. Além disso, observa-se que as TAQs adotadas pelos modelos oficiais indicam, por exemplo, que caminhões e ônibus de estrada possam acumular mais de cinco milhões de quilômetros, o que parece incompatível com a realidade.

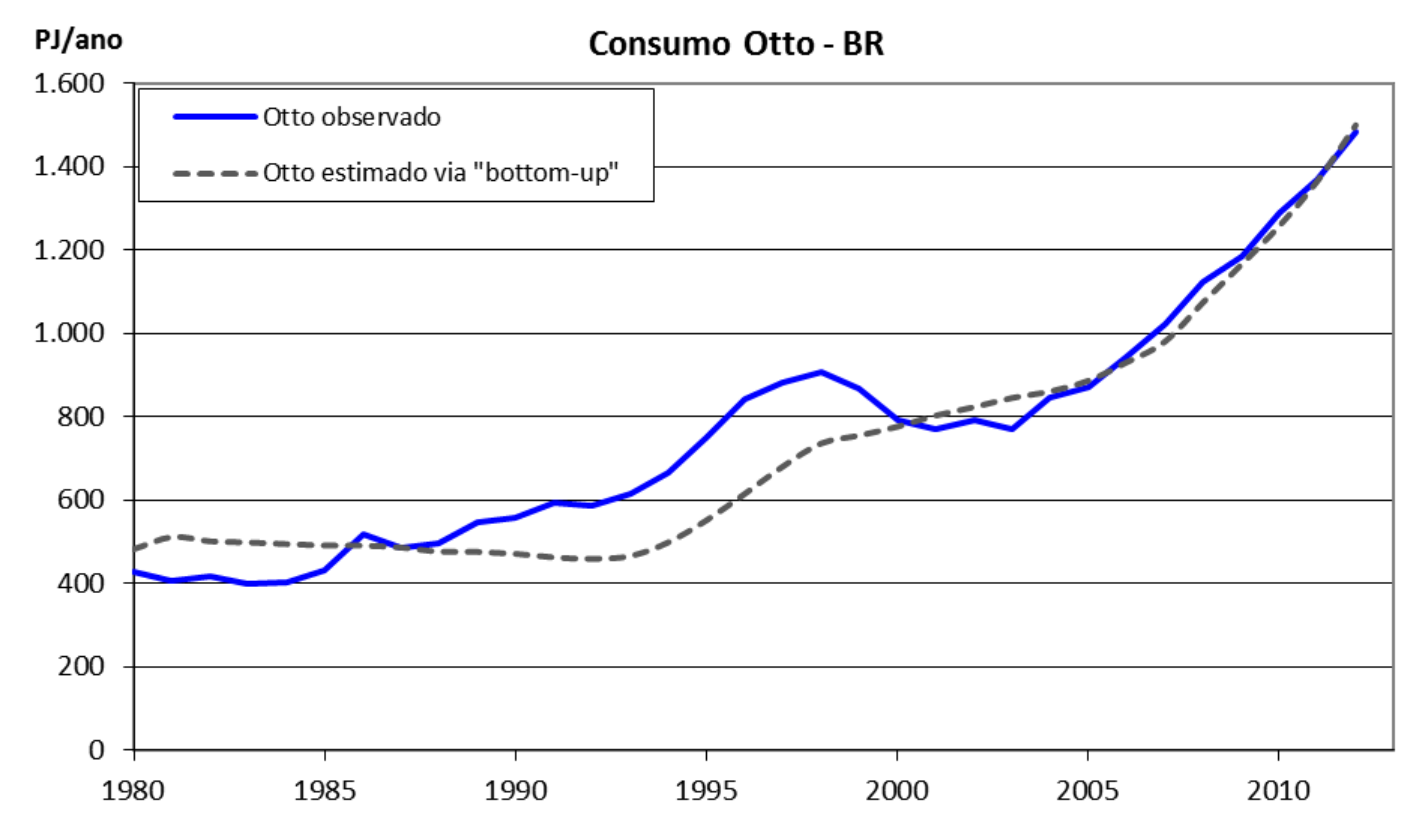

Ilustração 4.5 - Ajuste do modelo "bottom-up" - Otto anual no Brasil.

Fonte: Elaborado pelo autor, conforme descrito. 
De qualquer forma, apesar desse procedimento permitir obter a melhor solução de compromisso entre o modelo e a realidade, ainda observa-se um significativo descolamento entre as duas curvas em torno do meio do período considerado. O motivo desse descolamento pode também afetar resultados futuros, o que foi mais uma razão para se investigar sua causa.

Convém mencionar que a ferramenta utilizada contém campos para ajustar o número de veículos a álcool vendidos na região, a fração de veículos “flex" rodando com gasolina ou etanol e a fração de veículos convertidos para GNV rodando com estes combustíveis. Entretanto, esses campos só foram utilizados, após os parâmetros que afetam os consumos dos conjuntos dos combustíveis Otto e Diesel haverem sido ajustados. Esses ajustes adicionais, se necessários, foram feitos, por exemplo, para compensar um maior número de veículos a álcool vendidos em São Paulo, a respeito dos quais não se obteve estatísticas robustas, e afetam somente os resultados individuais da gasolina, o etanol e o GNV.

E ainda que esta ferramenta também leva em consideração: as variações que ocorreram do teor de etanol e de biodiesel adicionados à gasolina $\mathrm{C}$ e ao óleo diesel; e estimativas da variação, ao longo do tempo, do tamanho e da eficiência energética dos motores dos veículos pesados, permitindo que essas grandezas possam ser o objeto de estudos utilizando essa ferramenta.

Também foram introduzidos campos, visando um futuro uso para quando se dispuser da informação correspondente, como por exemplo, o decréscimo da autonomia em função da condição de uso, para possibilitar avaliar, por exemplo, a influência dos congestionamentos, e o acréscimo do consumo em função da idade dos veículos, para avaliar, por exemplo, o impacto dos programas de inspeção veicular.

\subsection{Desenvolvimento do modelo econométrico}

A suspeita sobre a causa do descolamento anteriormente observado recaiu sobre a influência de fatores econômicos. Ao avaliar outros casos, constatou-se que, além de historicamente o consumo de combustíveis não acompanhar a evolução da frota, consumo e frota crescem a taxas diferenciadas. Para melhor visualizar esse fato, foi elaborado o gráfico apresentado na Ilustração 4.6, que mostra a evolução relativa a partir de 1980 das frotas dos inventários oficiais e dos consumos.

Em função das diferenças nas características e condições de uso, a frota e os combustíveis foram segregados em dois blocos: Otto e Diesel. O primeiro agrupando as frotas de motociclos, automóveis e comerciais leves com motores ciclo Otto, consumindo gasolina C, etanol e GNV, 
e o segundo agrupando as frotas de comerciais leves, ônibus e caminhões com motores ciclo Diesel, consumindo óleo diesel e biodiesel. Além disso, para esse propósito, as frotas das diferentes categorias foram agrupadas no que se denominou "frota equivalente", que é a união dessas frotas em uma tomada como referência, com base na proporcionalidade dos consumos.

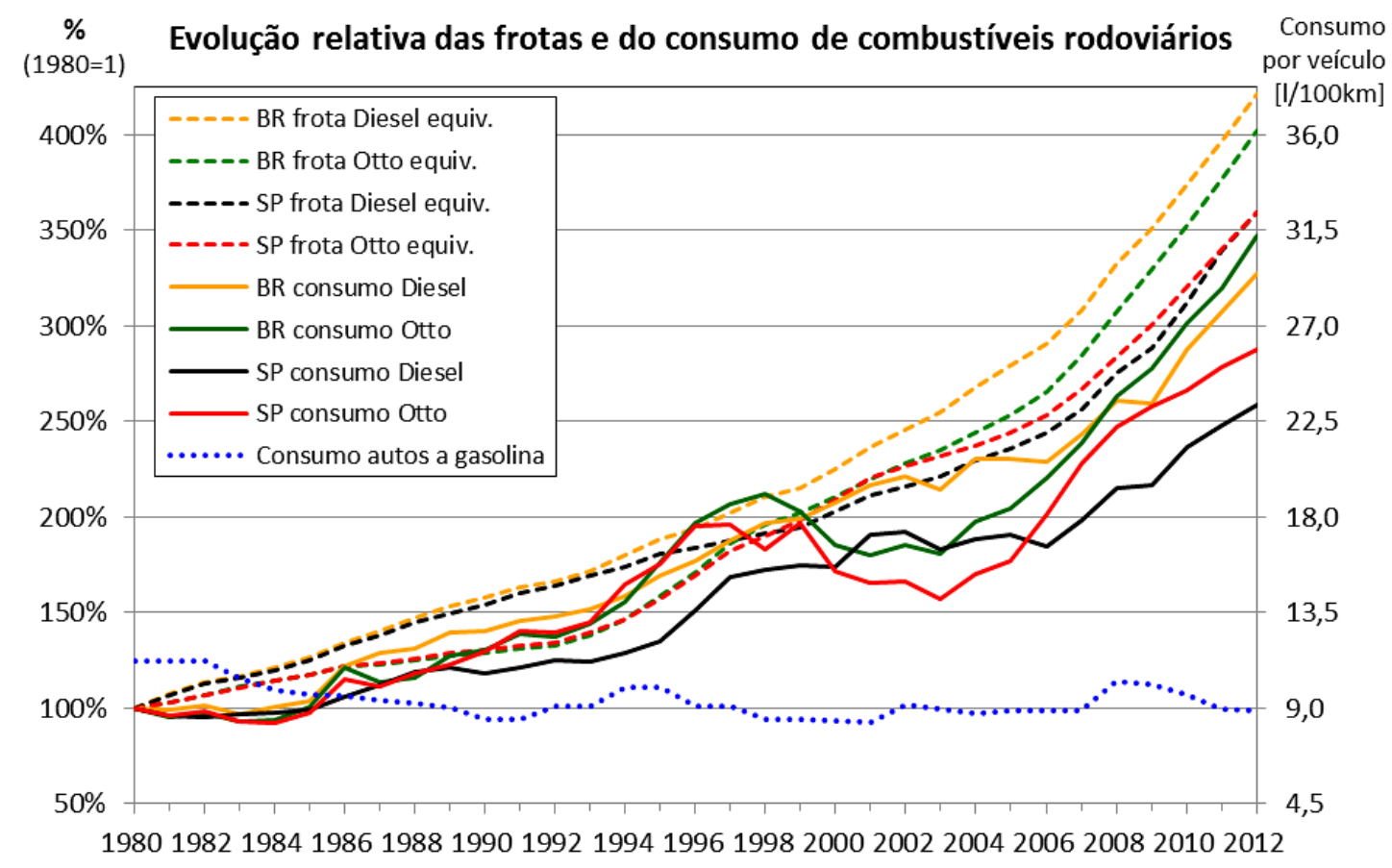

Ilustração 4.6 - Evolução relativa das frotas e dos consumos no Brasil e em São Paulo.

Fonte: Elaborado pelo autor com base em dados do "10 Inventário Nacional", do relatório "Emissões veiculares no estado de São Paulo 2012", do BEN e da ANP.

No caso dos veículos Otto utilizou-se como referência a frota de automóveis, e dos veículos Diesel a frota de caminhões médios. Exemplificando, para que a frota de motociclos fosse adicionada à "frota equivalente" de automóveis, pelo fato dos motociclos consumirem menos, ela foi antes reduzida proporcionalmente à razão dos consumos motociclo-automóvel. Como no final se utilizou a evolução relativa da "frota equivalente", o resultado independe da frota tomada como referência. Também se assumiu que o consumo energético dos veículos de uma categoria rodando com gasolina $\mathrm{C}$, etanol ou GNV é o mesmo, fato em parte corroborado pelos consumos médios dos automóveis "flex" rodando com gasolina $\mathrm{C}$ ou etanol levantados em anos recentes, conforma consta no relatório da CETESB (CETESB 2013). É também apresentada, no gráfico anterior, a evolução do consumo médio, em 1/100 km, dos automóveis levantado segundo procedimento padronizado, para ilustrar que não é o aumento de eficiência que justifica as diferenças nas taxas de crescimento da frota e do consumo totalizado dos veículos leves. Na busca de maior eficiência, convém lembrar que também há uma tendência de se 
utilizar caminhões cada vez maiores, o que seria mesmo antagônico à maior taxa de crescimento da frota de veículos pesados. Esses fatos sugerem que as taxas de acumulação de quilometragem ou as taxas de sobrevivência reais, estas implicando em uma frota estimada menor, são inferiores às adotadas.

Conclui-se, em função das diferenças entre taxas de crescimento das frotas e taxas de crescimento dos correspondentes consumos totalizados, que a projeção do consumo e das emissões não pode se basear exclusivamente no crescimento das frotas. Além disso, verifica-se também necessidade de considerar variações decorrentes do nível de atividade econômica. Nos modelos oficiais isso é feito por meio do fator de ajuste da intensidade de uso. Porém, como esse fator se baseia no consumo observado, em função de sua variação, não há, em princípio, condição para projetá-lo. Para tanto, é necessário dispor de um modelo econométrico.

Iniciamos o desenvolvimento do modelo econométrico pelo levantamento detalhado dos consumos e dos preços dos combustíveis automotivos. Foram compilados os dados mensais por estado, de consumo em $\mathrm{m}^{3}$ a partir de janeiro de $2000^{106}$ e de preço nominal em Reais a partir de julho de $2001^{107}$, disponíveis no sítio da ANP e, especificamente do consumo de GNV, disponíveis no sítio da ABEGAS. Esses dados são apresentados nas planilhas "m3gasC"; "m3gasA"; "m3eac"; “m3ehc"; “m3gnv"; “m3Bx"; "m3die”; “m3b100”; "\$gasC”; "\$ehc"; “\$gnv” e \$Bx”. Para datas anteriores a estas, utilizaram-se dados anuais do Balanço Energético Nacional 2012 (EPE 2012) e do Balanço Energético do Estado de São Paulo 2012 (SÃO PAULO 2012), para cada um dos casos considerados. Para evitar qualquer problema associado às unidades, os dados de consumo volumétrico $\left(\mathrm{em}^{3}\right.$ ) foram convertidos para consumo energético (em Joules), utilizando os fatores de conversão do BEN. No cálculo do consumo energético da gasolina C levou-se em consideração a variação do teor de etanol anidro ao longo do tempo ${ }^{108}$. O mesmo procedimento foi aplicado ao biodiesel, em relação ao teor de B100 adicionado ao óleo diesel. Esses dados foram consolidados especificamente para o Brasil e São Paulo nas planilhas "BR" e "SP". No cálculo do preço médio brasileiro, levaram-se em

\footnotetext{
106 Disponível em <http://www.anp.gov.br/?pg=64555\&m=\&t1=\&t2=\&t3=\&t4=\&ar=\&ps=\&cachebust=137658 9732698>, acessado em 15/08/2013.

${ }^{107}$ Disponível em <http://www.anp.gov.br/preco/>, acessado em 15/08/2013.

108 Esta informação está disponível em <http://www.agricultura.gov.br/arq_editor/file/Desenvolvimento_ Sustentavel/Agroenergia/Orientacoes_Tecnicas/01-Mistura\%20etanol\%20anidro-gasolina-CRONOLOGIA (Atualiz_02_09_2011).pdf>, acessado em 15/08/2013.
} 
consideração os volumes consumidos em cada estado e período. Os preços nominais foram corrigidos para janeiro de 2013 pelo INPC.

O segundo passo foi obter, nos períodos correspondentes, indicadores econômicos candidatos para se correlacionar com o consumo totalizado e, portanto, justificar sua evolução. Convém destacar que, assim como ocorre com os dados da frota, não foi uma tarefa fácil conseguir séries históricas coerentes para os períodos desejados. Foram encontradas algumas lacunas, inconsistências e incompatibilidades entre diferentes tabelas de dados, inclusive de mesma fonte, mesmo para os poucos indicadores selecionados. Prováveis origens desse problema são, em parte, os períodos de alta inflação, os diversos planos econômicos, mudanças nos procedimentos de coleta e tratamento dos dados, e o fato de alguns dados recentes ainda serem provisórios. As lacunas foram preenchidas por interpolações lineares. Quando observadas incompatibilidades, selecionaram-se aqueles dados que pareciam melhor se ajustar a sequência. As possíveis inconsistências foram transferidas para o modelo e são visíveis nos resultados alcançados.

Os indicadores empregados são, além do preço dos combustíveis, o PIB e o rendimento médio nominal do trabalho principal das pessoas ocupadas de 15 anos e mais ${ }^{109}$. Os valores monetários desses parâmetros foram corrigidos pelo INPC. No caso de dados anuais utilizou-se como referência a data de setembro de 2012, o mesmo mês empregado pelo IBGE como referência para o PIB anual. No caso de dados mensais, adotou-se como referência janeiro de 2013. Os dados de INPC, PIB e rendimento médio nominal são apresentados nas planilhas "INPC"; "PIB mensal BR e SP"; "PIB anual BR e SP" e "IBGE PME neo t16 1991+".

A pertinência do emprego dos indicadores pré-selecionados como variáveis preditoras do consumo de combustível foi verificada por regressão linear. Foram testados dados mensais e anuais do PIB isoladamente, identificado como o mais importante preditor, ou em conjunto com as possíveis combinações dos outros indicadores (preço dos combustíveis e rendimento médio da população). O objetivo de aplicar o procedimento aos dados mensais foi principalmente o de verificar a pertinência da técnica empregada com dados mais robustos e em maior número, uma vez que os inventários utilizam dados anualizados.

109 Disponível em <http://www.sidra.ibge.gov.br/bda/tabela/listabl.asp?c=16\&z=t\&o=16>, acessado em $15 / 08 / 2013$. 
Naturalmente, o tamanho da amostra foi limitado pelo indicador com menor número de dados, que no caso dos dados mensais foram os preços dos combustíveis (de julho de 2001 a dezembro de 2012), e no dos dados anuais os rendimentos médios da população (de 1991 a 2012) e o consumo de combustíveis em São Paulo (de 1980 a 2012). Foram utilizados os dados específicos do Brasil e do estado de São Paulo, à exceção dos preços anuais dos combustíveis anteriores a 2001, disponíveis somente no BEN. Para São Paulo nesse período foram utilizadas estimativas baseadas no BEN e a diferença de preço média observada deste estado em relação ao Brasil nos anos seguintes. Ressalve-se também que foram localizados somente dados trimestrais do PIB brasileiro, os quais foram interpolados linearmente.

Para permitir a visualização gráfica da evolução do conjunto desses parâmetros, esses dados foram relativizados utilizando as mesmas referências temporais. Por exemplo, atribui-se ao preço do óleo diesel em dezembro de 2012 o valor um, e os demais derivaram deste. Os conjuntos de dados econômicos e de consumos, mensais e anuais, as frotas dos inventários, o cálculo das frotas equivalentes, as diversas regressões lineares realizadas e seus correspondentes coeficientes e parâmetros estatísticos estão consolidados nas planilhas, respectivamente para o Brasil e São Paulo, “consBR” e “consSP”.

Os melhores resultados obtidos são apresentados nas ilustrações a seguir, onde é possível visualizar a qualidade da aderência da equação de regressão aos dados de consumo e a influência de cada indicador no resultado. Nessas ilustrações também são apresentadas as estatísticas da regressão com confiança de 95\%, para os diversos casos considerados. Um resumo sobre essas estatísticas é apresentado no Anexo A. Como antecipado, algumas aparentes inconsistências nos dados econômicos afetam significativamente os resultados do modelo preditor como, por exemplo, a variação do PIB anual paulista em 2002. Caso se deseje refinar os resultados do modelo econométrico, conviria que elas fossem avaliadas e, se se justificar, revistas. Caso se consiga e se deseje adicionar novos indicadores econômicos ao modelo, o mesmo procedimento poderá ser utilizado.

Como pode ser visto na Ilustração 4.9, as variáveis preditoras não são capazes de explicar as variações sazonais mensais no caso do Diesel, o que resulta em coeficientes de determinação $\left(\mathrm{R}^{2}\right)$ piores. Nos dados anuais, que filtram as sazonalidades, obteve-se $\mathrm{R}^{2}$ bem superiores. Em contrapartida, neste caso o preço e o rendimento pouco ou nada contribuíram para melhorar a aderência da equação de regressão. Entretanto, convém ressaltar a maior fragilidade dos dados anteriores a 2001, sobretudo do preço dos combustíveis de São Paulo. 

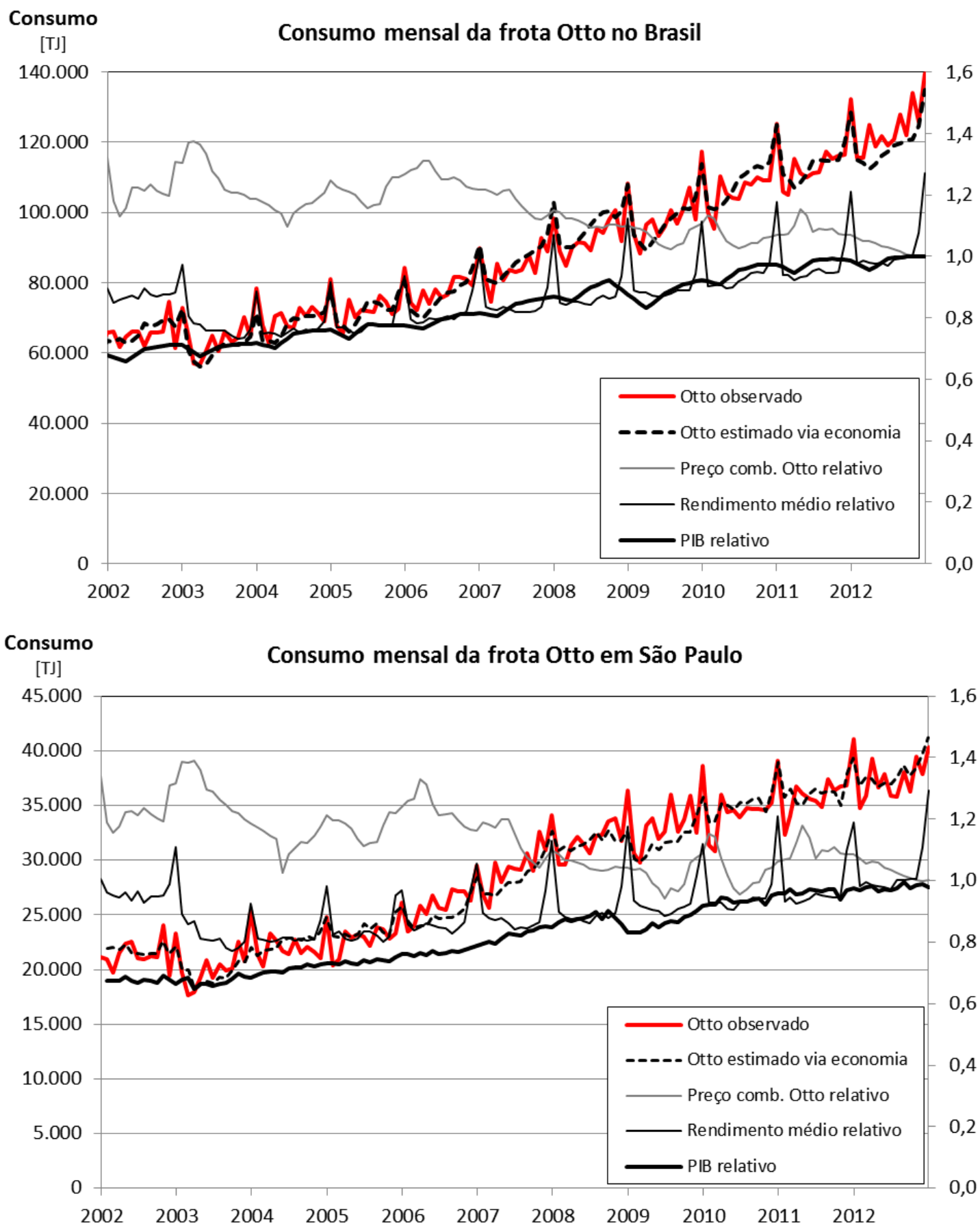

\begin{tabular}{ccccccccccc}
\hline \multirow{2}{*}{ Região } & \multirow{2}{*}{$\mathbf{N}^{\circ}$ obs. } & \multirow{2}{*}{$\mathbf{R}^{2}$} & \multirow{2}{*}{ Teste $\mathbf{F}$} & $\begin{array}{c}\text { Erro } \\
\text { padrão }\end{array}$ & \multicolumn{3}{c}{ Teste t } & \multicolumn{3}{c}{ Coeficiente } \\
\hline BR & 138 & 0,960 & 1.067 & 4.167 & 25,7 & 10,7 & $-3,34$ & 139.075 & 53.032 & -21.609 \\
SP & 132 & 0,943 & 711 & 1.527 & 25,2 & 6,53 & $-3,26$ & 47.193 & 11.001 & -6.683 \\
\hline \multicolumn{2}{l}{ Limite para hipótese nula } & \multicolumn{2}{c}{$\mathrm{F}_{(0,05 ; 3 ; 134)}=2,60$} & \multicolumn{2}{c}{$\mathrm{t}_{(0,025 ; 134)}=1,960$} & & & \\
\hline
\end{tabular}

Ilustração 4.7 - Ajuste do modelo econométrico - Otto mensal no Brasil e em São Paulo.

Fonte: Elaborado pelo autor, conforme descrito. 

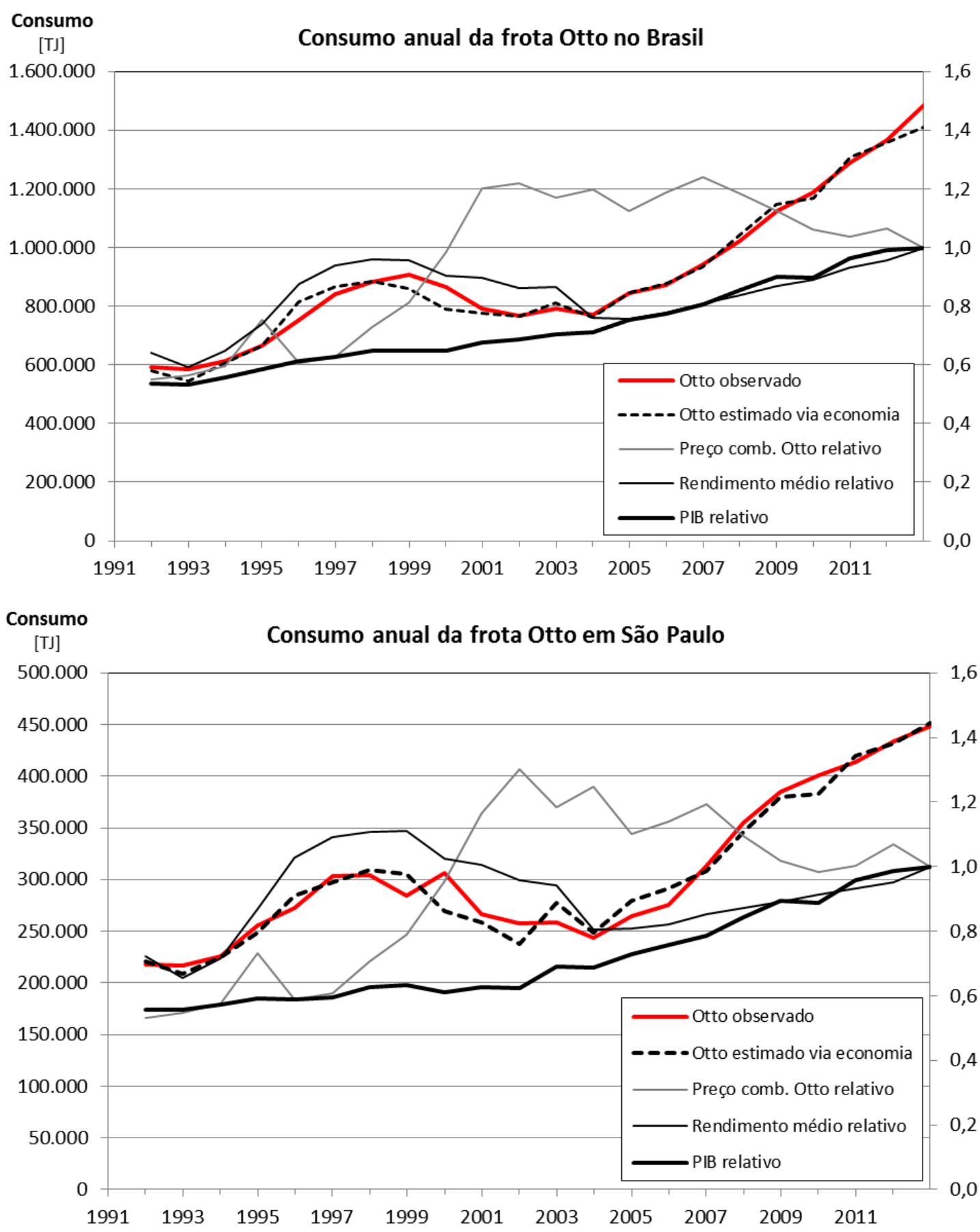

\begin{tabular}{|c|c|c|c|c|c|c|c|c|c|c|}
\hline \multirow{2}{*}{ Região } & \multirow{2}{*}{$\mathbf{N}^{\circ}$ obs. } & \multirow{2}{*}{$\mathbf{R}^{2}$} & \multirow{2}{*}{ Teste F } & \multirow{2}{*}{$\begin{array}{c}\text { Erro } \\
\text { padrão }\end{array}$} & \multicolumn{3}{|c|}{ Teste $t$} & \multicolumn{3}{|c|}{ Coeficiente } \\
\hline & & & & & PIB & Rend. & Preço & PIB & Rend. & Preço \\
\hline $\mathrm{BR}$ & 22 & 0,983 & 351 & 34.537 & 21,6 & 6,64 & $-6,73$ & $1.634 \mathrm{E} 3$ & $530 \mathrm{E} 3$ & $-264 \mathrm{E} 3$ \\
\hline SP & 22 & 0,963 & 156 & 14.671 & 18,7 & 6,70 & $-4,49$ & $489 \mathrm{E} 3$ & $170 \mathrm{E} 3$ & $-72.2 \mathrm{E} 3$ \\
\hline \multicolumn{3}{|c|}{ Limite para hipótese nula } & $\mathrm{F}_{(0,05 ; 3 ; 1}$ & $=3,16$ & \multicolumn{3}{|c|}{$\mathrm{t}_{(0,025 ; 18)}=2,101$} & & & \\
\hline
\end{tabular}

Ilustração 4.8 - Ajuste do modelo econométrico - Otto anual no Brasil e em São Paulo.

Fonte: Elaborado pelo autor, conforme descrito. 

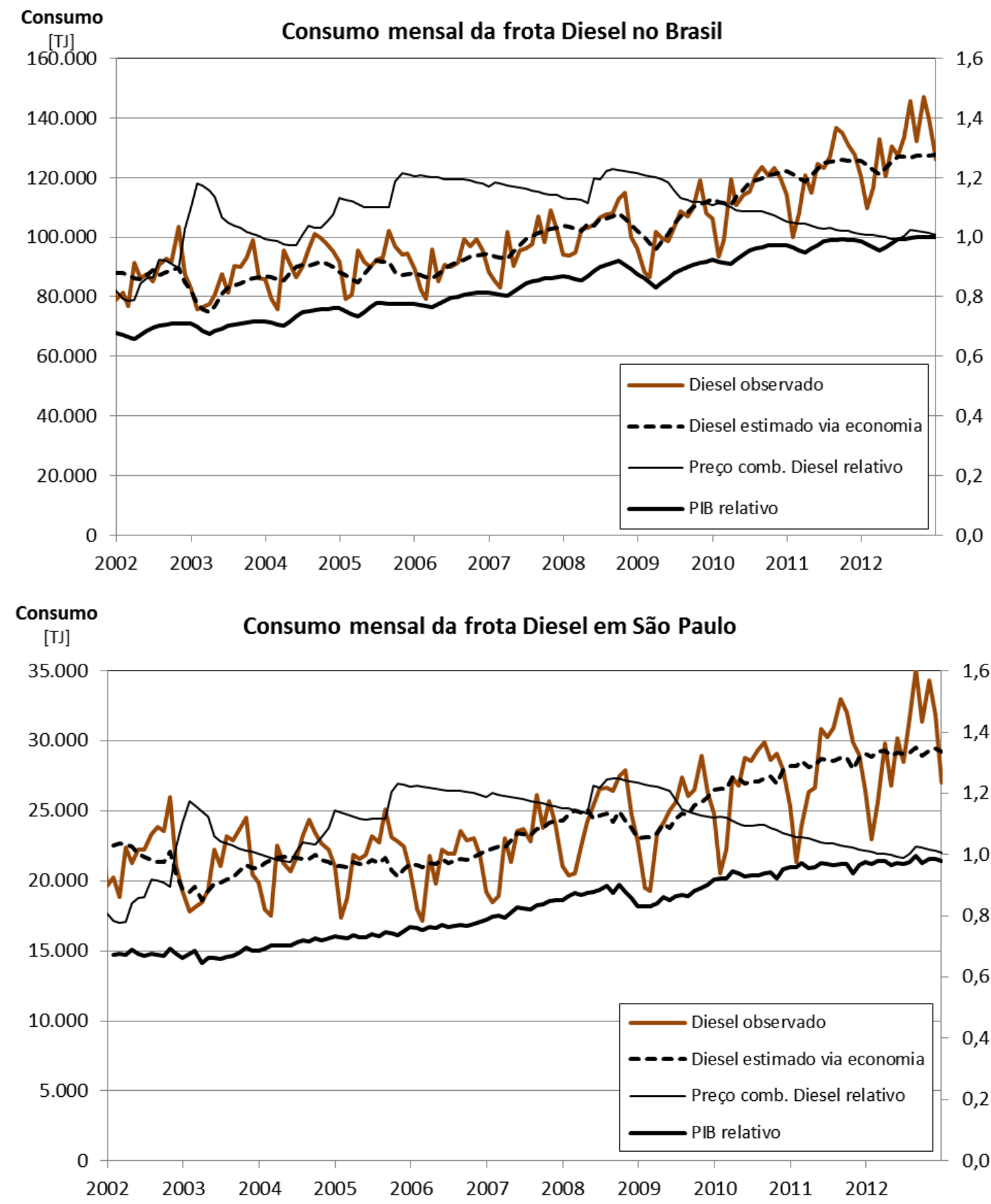

\begin{tabular}{ccccccccccc}
\hline \multirow{2}{*}{ Região } & \multirow{2}{*}{$\mathbf{N}^{\circ}$ obs. } & \multirow{2}{*}{$\mathbf{R}^{2}$} & \multirow{2}{*}{ Teste $\mathbf{F}$} & \multirow{2}{*}{$\begin{array}{c}\text { Erro } \\
\text { padrão }\end{array}$} & \multicolumn{3}{c}{ Teste t } & \multicolumn{3}{c}{ Coeficiente } \\
\hline BR & 138 & 0,820 & 307 & 6.906 & 24,8 & --- & $-7,55$ & 145.414 & --- & -37.213 \\
SP & 132 & 0,612 & 102 & 2.440 & 14,2 & --- & $-4,62$ & 28.315 & --- & -8.833 \\
\hline Limite para hipótese nula & $\mathrm{F}_{(0,05 ; 2 ; 135)}=3,00$ & \multicolumn{2}{c}{$\mathrm{t}_{(0,025 ; 135)}=1,960$} & & & \\
\hline
\end{tabular}

Ilustração 4.9 - Ajuste do modelo econométrico - Diesel mensal no Brasil e em São Paulo.

Fonte: Elaborado pelo autor, conforme descrito. 

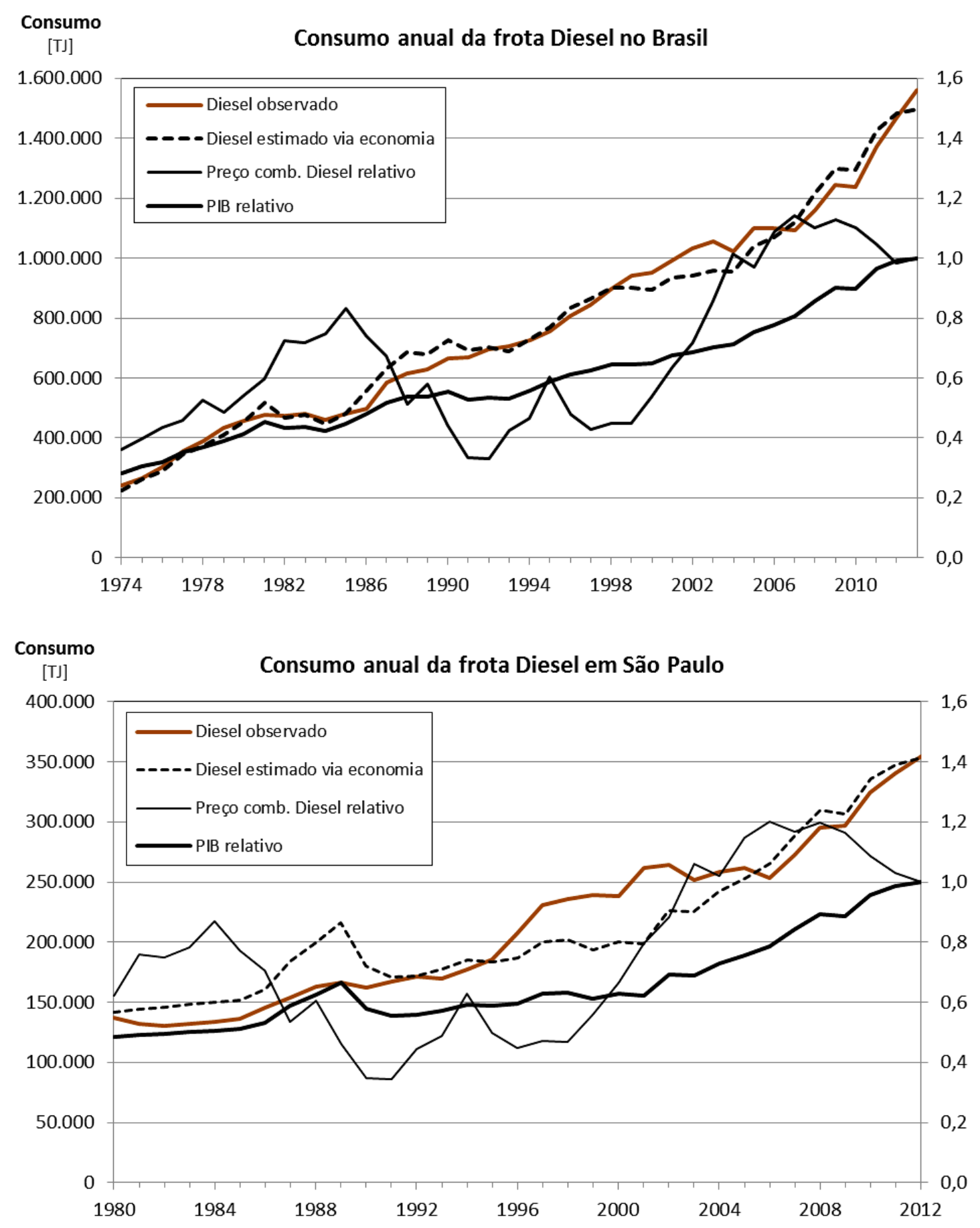

\begin{tabular}{|c|c|c|c|c|c|c|c|c|c|c|}
\hline \multirow{2}{*}{ Região } & \multirow{2}{*}{$\mathbf{N}^{\circ}$ obs. } & \multirow{2}{*}{$\mathbf{R}^{2}$} & \multirow{2}{*}{ Teste F } & \multirow{2}{*}{$\begin{array}{c}\text { Erro } \\
\text { padrão }\end{array}$} & \multicolumn{3}{|c|}{ Teste $t$} & \multicolumn{3}{|c|}{ Coeficiente } \\
\hline & & & & & PIB & Rend. & Preço & PIB & Rend. & Preço \\
\hline $\mathrm{BR}$ & 40 & 0,984 & 1.125 & 45.080 & 33,8 & --- & $-2,78$ & $1.875 \mathrm{E} 3$ & --- & $-116 \mathrm{E} 3$ \\
\hline \multicolumn{3}{|c|}{ Limite para hipótese nula } & \multicolumn{2}{|c|}{$\mathrm{F}_{(0,05 ; 2 ; 37)}=3,52$} & \multicolumn{3}{|c|}{$\mathrm{t}_{(0,025 ; 37)}=2,093$} & & & \\
\hline SP & 33 & 0,859 & 189 & 25.410 & 13,7 & --- & --- & 411.572 & --- & --- \\
\hline \multicolumn{3}{|c|}{ Limite para hipótese nula } & \multicolumn{2}{|c|}{$\mathrm{F}_{(0,05 ; 1 ; 31)}=4,16$} & \multicolumn{3}{|c|}{$\mathrm{t}_{(0,025 ; 31)}=1,960$} & & & \\
\hline
\end{tabular}

Ilustração 4.10 - Ajuste do modelo econométrico - Diesel anual no Brasil e em São Paulo.

Fonte: Elaborado pelo autor, conforme descrito. 
Apesar do pior ajuste no caso do Diesel, sobretudo para São Paulo, com base nos parâmetros estatísticos é possível afirmar que, em linhas gerais, os modelos econométricos desenvolvidos são estatisticamente robustos e podem ser utilizados para prognosticar a evolução do consumo de combustíveis e, consequentemente, das emissões de $\mathrm{CO}_{2}$, em função da projeção da evolução do PIB e do preço dos combustíveis e, particularmente para o combustível Otto, do rendimento médio da população. Nesse caso, as incertezas serão aquelas associadas ao erro padrão do modelo correspondente. No que tange ao modelo híbrido abaixo, as incertezas desse modelo econométrico comporão com as demais incertezas do modelo "botton-up".

Como pode ser visto na Ilustração 4.11, o consumo Otto brasileiro obtido por meio do modelo econométrico possibilita um ajuste significativamente melhor que aquele obtido pelo modelo "bottom-up". Em conjunto com as participações dos diferentes combustíveis e correspondentes $\mathrm{ACV}$, os modelos econométricos permitem ainda calcular, por meio de modelos "top-down", as correspondentes emissões totais de $\mathrm{CO}_{2}$, desde que desvinculadas das caraterísticas da frota.

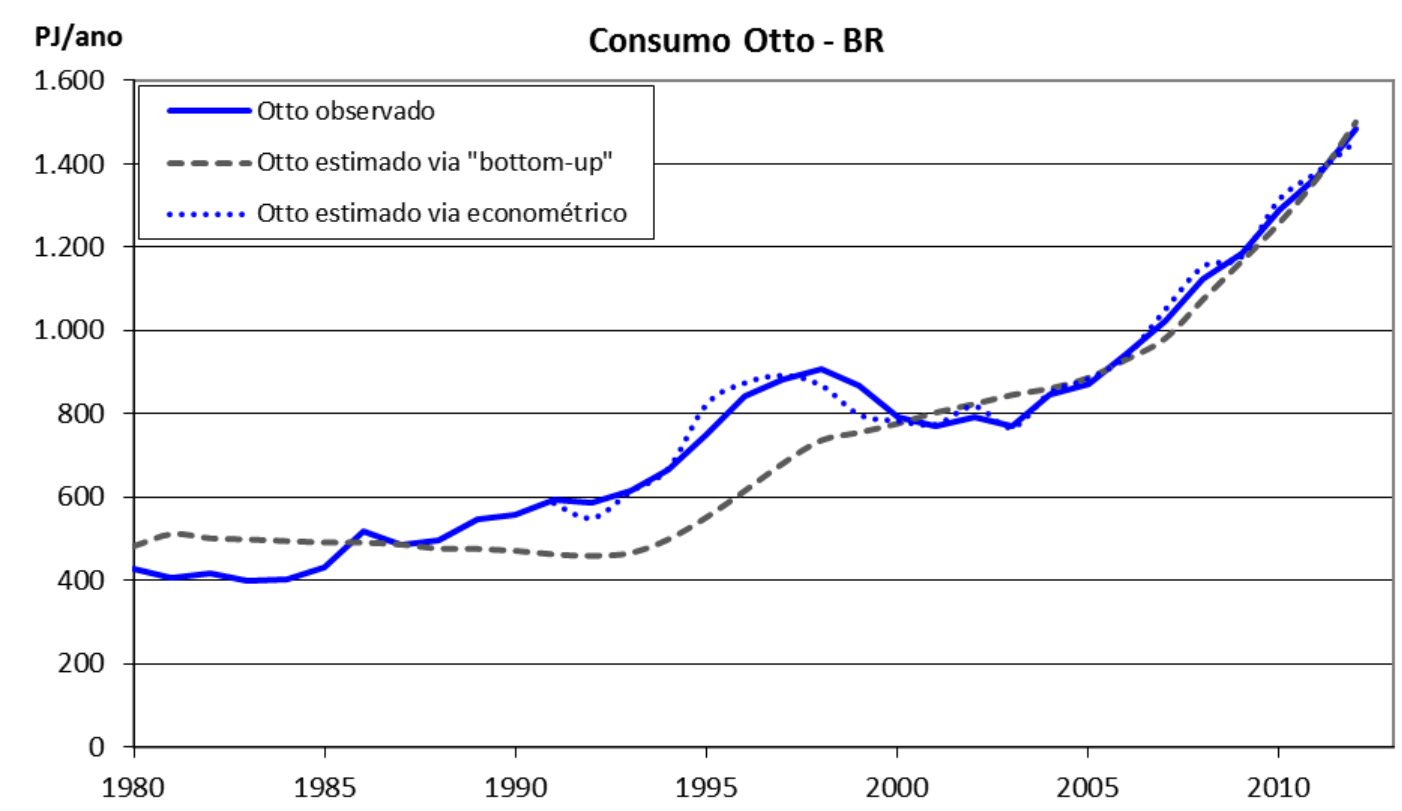

Ilustração 4.11 - Ajuste do modelo econométrico - Otto anual no Brasil.

Fonte: Elaborado pelo autor, conforme descrito.

\subsection{Desenvolvimento do modelo híbrido}

Para calcular ou projetar o consumo de combustível ou a emissão de $\mathrm{CO}_{2}$ de parcelas da frota, ou ainda as demais emissões veiculares, é necessário considerar as caraterísticas da frota. Portanto, o próximo passo foi encontrar uma forma de incorporar a informação provida pelos modelos econométricos no modelo "bottom-up". 
Mesmo que uma mudança econômica afete a venda de veículos, muito antes de ela influenciar o tamanho e a composição da frota, ela primeiro afetará o uso dos veículos, o que no modelo de inventário é expresso pela acumulação de quilometragem. Ou seja, era necessário descobrir um fator multiplicador das quilometragens de cada segmento em cada ano $\left(V K T_{f, v, t}\right)$ que levasse em consideração a evolução do consumo, calculada pelo modelo econométrico, e simultaneamente a evolução da frota, com as diversas classes veiculares crescendo a diferentes taxas e tendo diferentes pesos no consumo totalizado.

Isso parecia um problema de difícil solução, que no final mostrou-se relativamente simples com o uso da grandeza anteriormente estabelecida "frota equivalente", que é definida justamente em função do número de veículos ponderado pelo consumo de cada classe. Porém, para que o resultado independesse do segmento da frota tomado como referência, e para que as evoluções do consumo e da frota fossem comparáveis, no lugar de seus valores absolutos, foram utilizados seus valores relativos.

Assumindo que no longo prazo a diferença entre as taxas de crescimento médio do consumo e da frota é uniforme, o multiplicador desejado foi obtido por meio da seguinte fórmula:

$$
\text { Econ }_{f}=1+\left(\text { Consumo }_{f}-\text { FrotaEquiv }_{f}\right)
$$

onde Econ $_{f} \quad$ é o fator multiplicador do conjunto de combustíveis $f$ (Otto ou Diesel) que reflete a influência da situação econômica sobre a atividade.

Consumo $_{f}$ é a razão entre o consumo do combustível $f$ do ano considerado e o consumo de um ano tomado como referência, calculados pelo modelo econométrico.

FrotaEquiv $_{f}$ é a razão entre a frota equivalente do ano considerado e a frota equivalente de um ano tomado como referência, calculadas pelo modelo híbrido.

Os indicadores econômicos e o cálculo dos coeficientes da regressão linear dos modelos econométricos utilizados estão nas planilhas "consBR" e "consSP". Esses dados foram transpostos para a planilha "PremissasH", onde, com os dados do novo modelo, inclusive aqueles resultantes dos ajustes, também são calculadas as "frotas equivalentes" e, em função desses, os fatores multiplicadores. Por meio dessas funções, os modelos econométricos são incorporados ao modelo "botton-up”, gerando, portanto, um novo modelo que é híbrido. 
Particularmente para o Diesel, visando possibilitar uma melhor projeção, foi utilizada uma solução diferenciada. Isso foi feito devido ao fato que na análise dos dados mensais verificouse que a influência do preço deste combustível no volume consumido era estatisticamente significativa, o que não se repetiu na análise dos dados anuais de São Paulo, supostamente devido à fragilidade destes dados. Como pode ser visto na planilha "PremissasH", empregou-se o seguinte artifício. Como a partir de 2001, os dados estatísticos, levantados pela ANP, são mais robustos, adotou-se este ano como referência para o cálculo dos valores relativos. Ele é também o ano médio entre 1990, o primeiro ano do qual se tem dados de todos os indicadores econômicos empregados, e 2012, o último ano considerado. Em função disso, anteriormente a 2001 inclusive, foi utilizado o modelo econométrico baseado exclusivamente no PIB e, posteriormente a 2001, o modelo que também considera a influência do preço. A continuidade desses dois modelos é possível porque ambos utilizam 2001 como referência.

Tomando novamente o exemplo do consumo Otto brasileiro, verifica-se pela Ilustração 4.12 que o modelo híbrido também possibilita um ajuste significativamente melhor que aquele obtido pelo modelo "bottom-up".

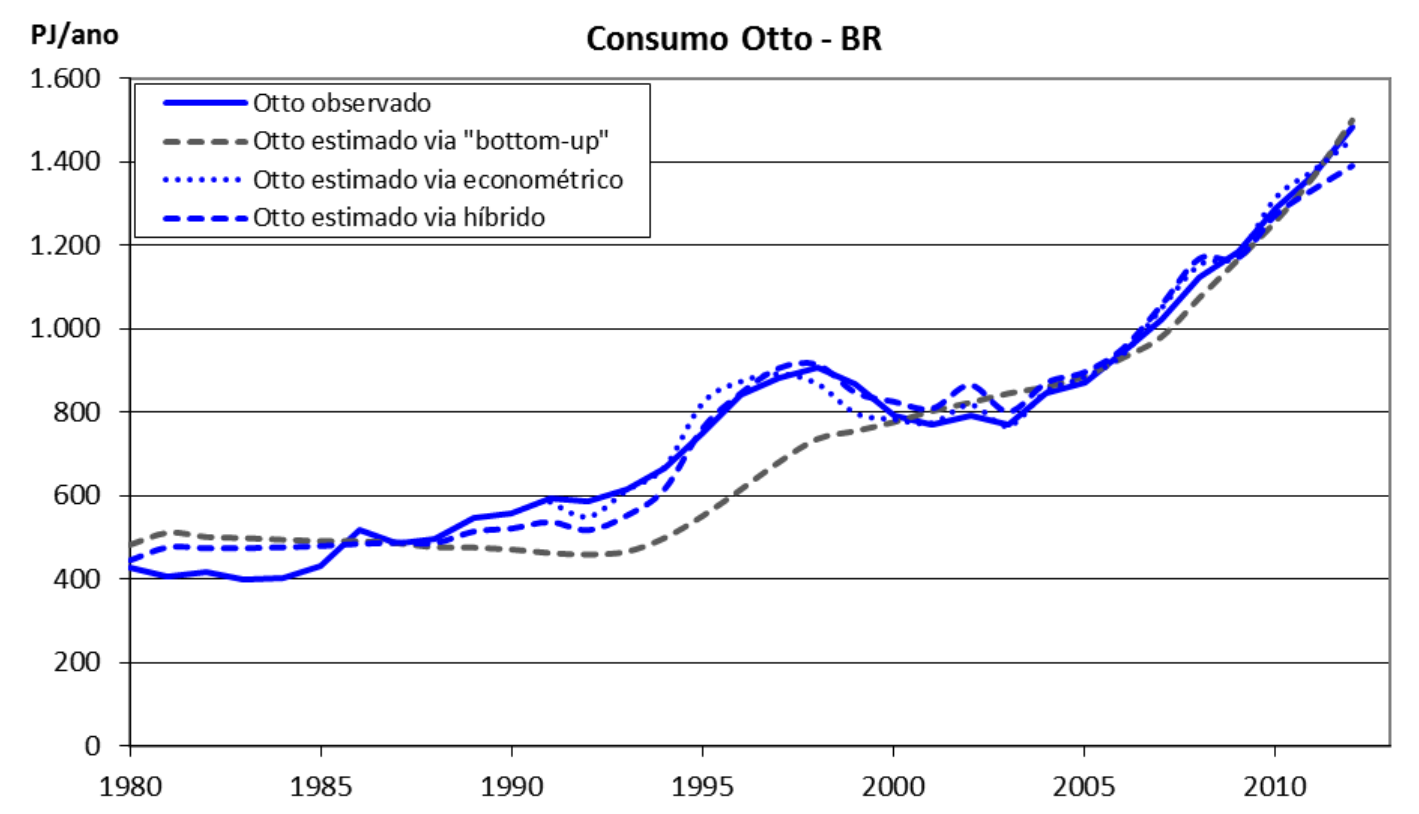

Ilustração 4.12 - Ajuste do modelo econométrico - Otto anual no Brasil.

Fonte: Elaborado pelo autor, conforme descrito.

Nas ilustrações a seguir, além dos gráficos da evolução dos consumos observados e calculados pelos modelos econométricos e híbrido, são apresentados parâmetros que corroboram estatisticamente a boa aderência dos resultados do modelo híbrido aos consumos observados no período mostrado. O cálculo desses parâmetros foi feito na planilha "Consumo". 

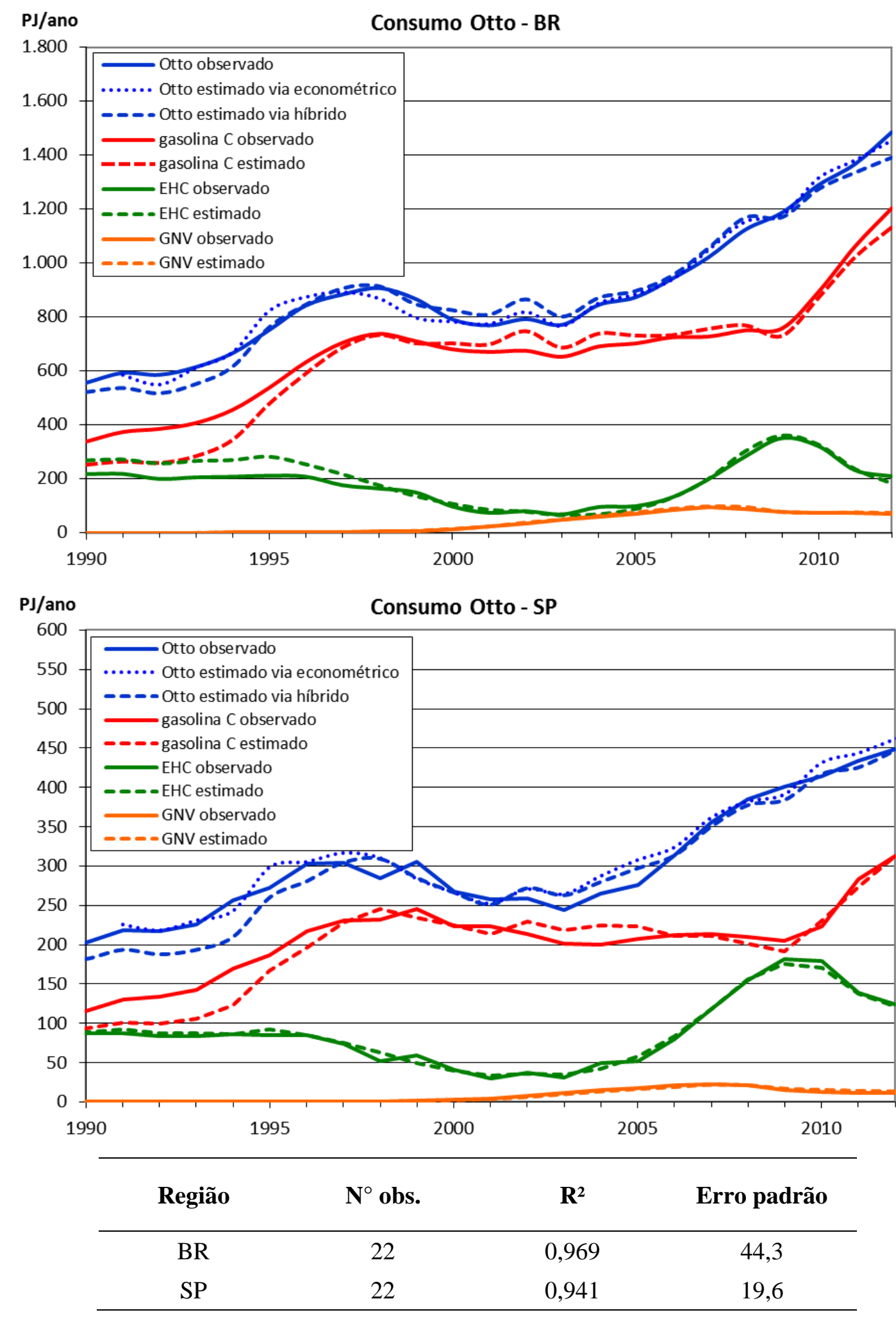

\section{Ilustração 4.13 - Ajuste do modelo híbrido - Otto no Brasil e em São Paulo.}

Fonte: Elaborado pelo autor, conforme descrito.

Os consumos estimados de gasolina C, EHC e GNV derivam dos demais dados do modelo, a exceção das frações "flex" rodando com etanol e de veículos convertidos rodando com GNV, que também foram ajustadas para compatibilizar com os consumos observados. 

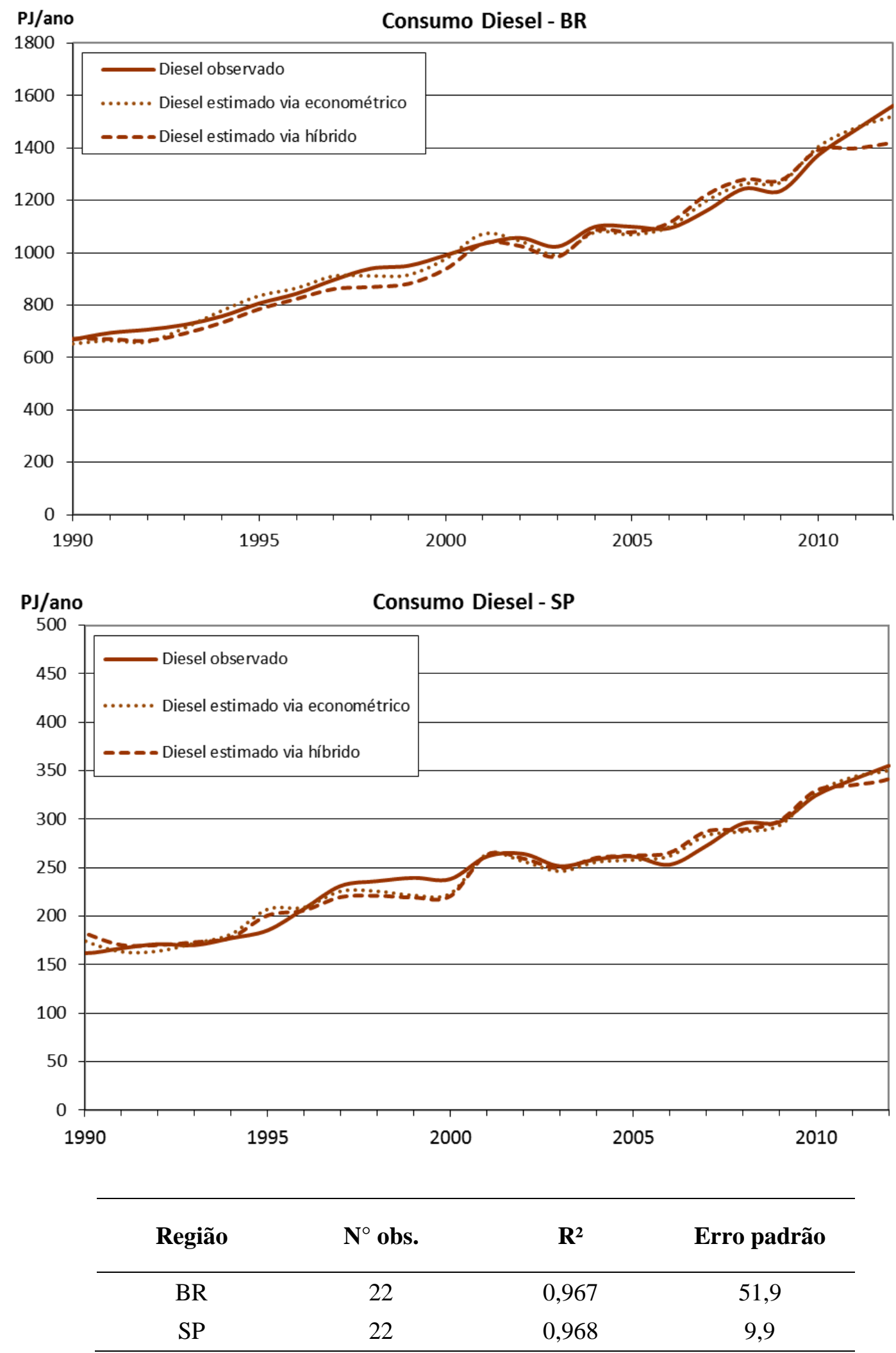

Ilustração 4.14 - Ajuste do modelo híbrido - Diesel no Brasil e em São Paulo.

Fonte: Elaborado pelo autor, conforme descrito. 
Convém aqui ressalvar que como os consumos observados também contém alguma imprecisão devida, por exemplo, a venda de combustíveis que ocorre fora do controle oficial, que os resultados estatísticos apresentados não são capazes de captar. De qualquer forma, isso só afeta os resultados da modelagem se o peso desses aspectos desconhecidos mudarem muito.

Algumas conclusões que podem ser derivadas desses gráficos são:

- Os modelos desenvolvidos são bastante sensíveis à consistência dos dados econômicos, como indica o pico de consumo observado em 2002 na Ilustração 4.13. Ao buscar-se o motivo desse pico, verificou que ele se devia ao valor do PIB indicado na tabela empregada, que particularmente no caso paulista é aparentemente inconsistente com o crescimento do país naquele ano $(6,36 \%$ contra 2,66\%). Em função do forte impacto desse número nos resultados, no modelo híbrido paulista, ele foi substituído por um valor estimado com base no crescimento brasileiro.

- O descolamento dos consumos calculados via modelo híbrido daqueles via modelo econométrico indica que diferenças nas taxas de crescimento do consumo e da frota podem comprometer a premissa adotada para a formulação do fator multiplicador $E_{c o n}$. Isso é válido tanto para o descolamento verificado anteriormente a 1990, decorrente da incomum evolução da frota de veículos pesados nesse período que pode ser observada na Ilustração 2.40, como também para o descolamento verificado nos últimos anos, provavelmente devido ao anormal crescimento da frota da ordem de $9 \%$ ao ano ocorrido entre 2010 e $2011^{110}$.

Apesar dessas excepcionalidades, os resultados estatísticos dos modelos permitem que eles sejam empregados para a realização de projeções dentro de faixas de incertezas conhecidas. Os modelos econométricos tanto podem ser empregados para projetar a emissão de $\mathrm{CO}_{2}$ via modelos "top-down" como, inseridos nos modelos "botton-up", robustecem os resultados destes. E o modelo híbrido resultante dessa inserção possibilita estimar a evolução das demais emissões veiculares no escapamento além do $\mathrm{CO}_{2}$.

\subsection{Premissas adotadas para a realização das projeções}

Arbitrariamente, as projeções realizadas foram estendidas até o ano de 2020.

\footnotetext{
${ }^{110} \mathrm{O}$ crescimento da venda de caminhões em 2010 em relação ao ano anterior foi de 43,5\% e de $10 \%$ no ano subsequente, possivelmente decorrente da antecipação das compras dos frotistas em função da implantação da fase P-7 do PROCONVE em 2012 e consequente necessidade do uso do ARLA 32.
} 
O primeiro passo visando à realização das projeções foi estimar, em função de sua evolução histórica, a divisão do mercado entre os diversos segmentos existentes, seja pelo combustível utilizado dos veículos leves ou pelo porte dos veículos pesados. O crescimento do número de veículos vendidos de cada segmento da frota foi estimado com base na taxa de crescimento média dos últimos anos. Entretanto, para filtrar as grandes variações que ocorrem no número de veículos vendidos ano a ano, que podem afetar a média de forma significativa dependendo do número de anos utilizados para o seu cálculo, em seu lugar preferiu-se utilizar as mais uniformes taxas de crescimento da frota. Como mostrado na planilha "Frota", foram calculadas as médias dos últimos 5, 10 e 15 anos. Levando em consideração da evolução dessas médias e as anormalidades recentes do mercado, entre essas foram adotadas as taxas, destacadas nessa planilha com fundo amarelo, que melhor pareciam representar uma tendência efetiva. Essas taxas foram aplicadas a partir de 2013 como as taxas de crescimento do número de veículos novos vendidos. Esse procedimento resultou nas projeções apresentadas nas ilustrações abaixo.
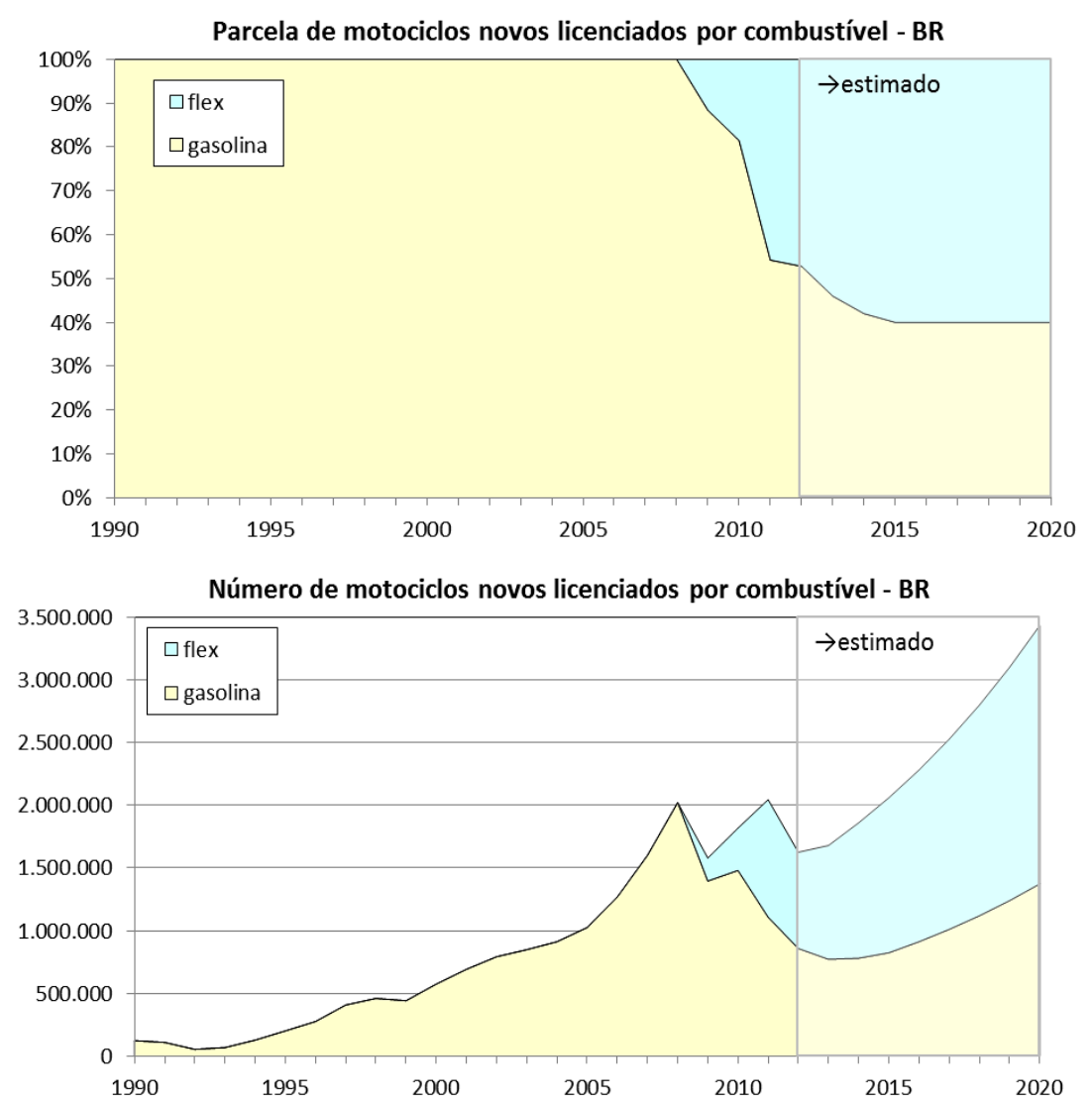

Ilustração 4.15 - Projeção da evolução de vendas e parcelas de motociclos novos.

Fonte: Elaborado pelo autor, conforme descrito. 

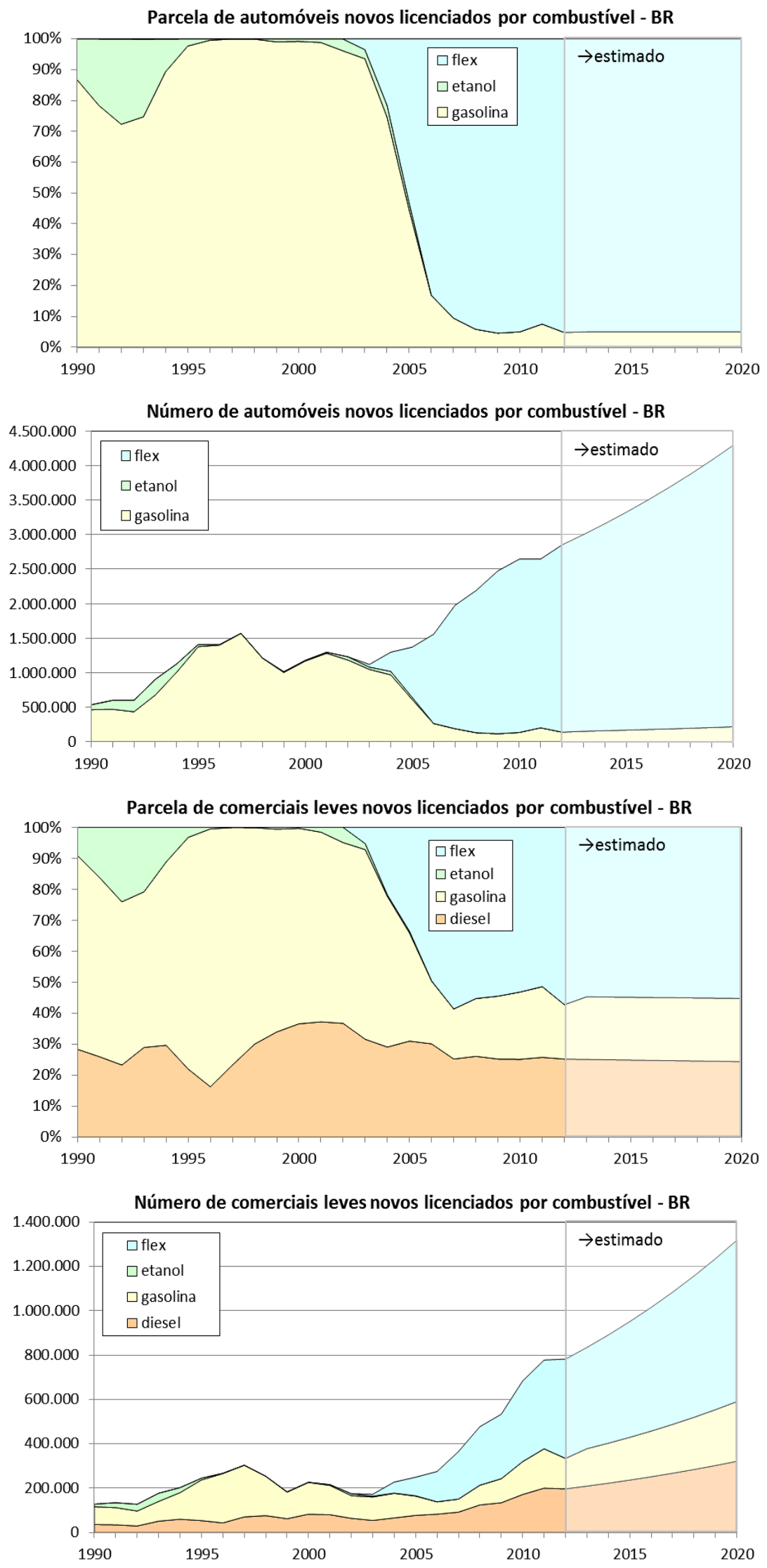

Ilustração 4.16 - Projeção da evolução de vendas e parcelas de veículos leves novos.

Fonte: Elaborado pelo autor, conforme descrito. 

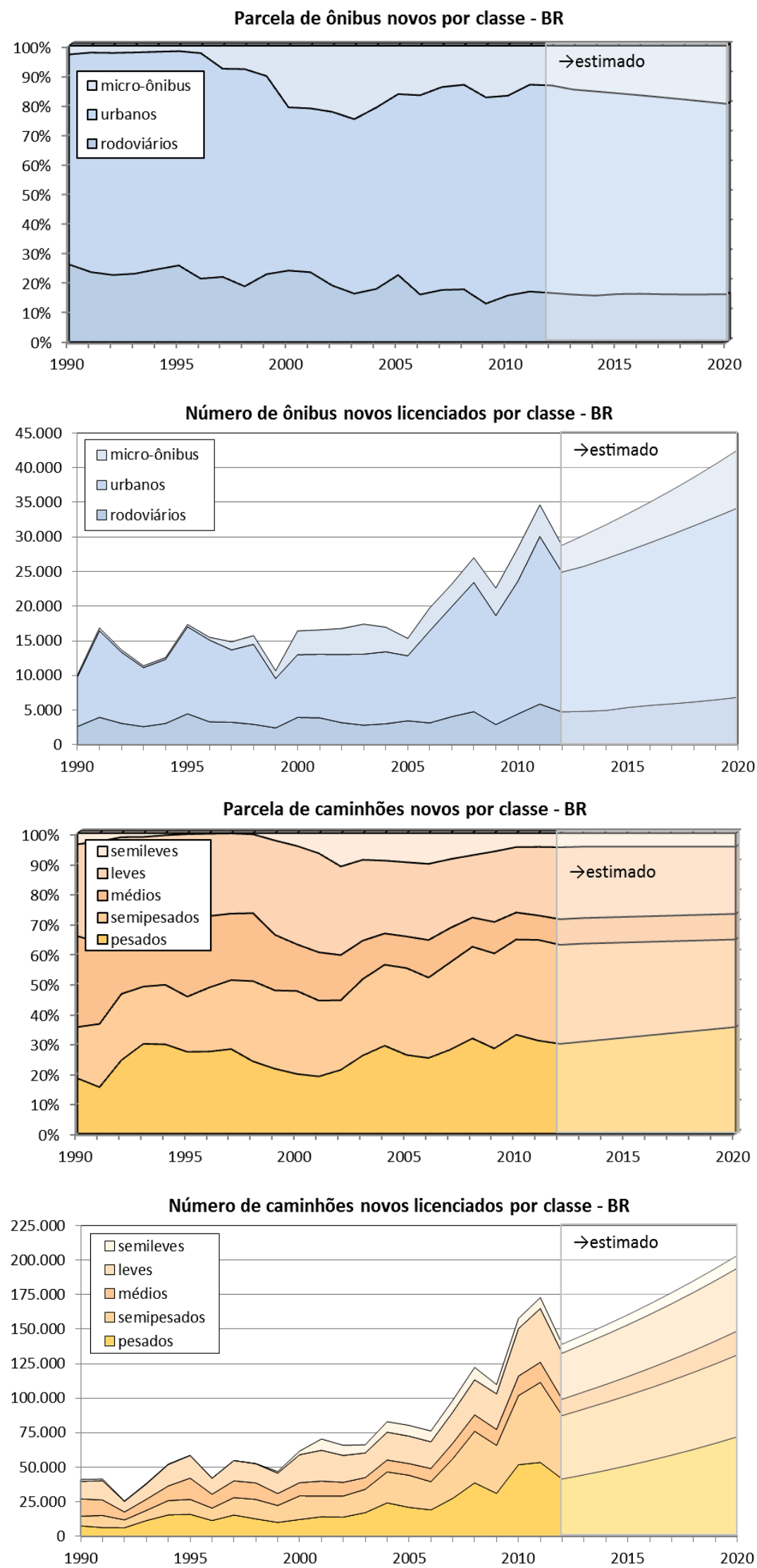

Ilustração 4.17 - Projeção da evolução de parcelas e vendas de veículos pesados novos.

Fonte: Elaborado pelo autor, conforme descrito. 
Apesar dessas projeções conterem uma grande margem de incerteza, convém destacar que a solução que será a seguir desenvolvida se baseia principalmente na evolução preconizada pelos modelos econométricos, que possuem incertezas conhecidas.

Outro ponto que merece ser destacado é que essas taxas de crescimento da frota estimadas, apesar de refletirem um período econômico favorável, são, como mostrado na Ilustração 4.5, em geral historicamente superiores às correspondentes taxas de crescimento dos consumos observados. Como essa diferença não é explicada por ganhos de eficiência, se de fato o modelo "bottom-up" reflete a realidade, isso indicaria que a intensidade de uso não cresce no mesmo ritmo do crescimento da frota. Ou seja, isso sugere que o crescimento econômico observado não comporta o crescimento no uso dos veículos em princípio apontado pelos modelos "bottom-up".

A melhor forma encontrada para levar essa diferença em consideração no modelo desenvolvido

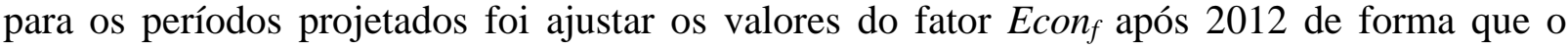
consumo projetado pelo modelo híbrido fosse compatível com o do modelo econométrico. Isto é, se utiliza as mais previsíveis projeções dos modelos econométricos, para balizar a projeção do modelo híbrido. Isso equivale aproximadamente à correção da intensidade de uso praticada pelos modelos oficiais, só que nesse caso no lugar de se utilizar o consumo observado, está se usando o consumo projetado pelo modelo econométrico. Aplicando esse procedimento para o caso brasileiro, resultou, para o cenário adotado como referência, nos gráficos apresentados na Ilustração 4.18. Esse ajuste está destacado na planilha "PremissasH". Esse procedimento neutraliza grande parte das incertezas relativas ao crescimento da frota anteriores.

Os cenários empregados neste estudo foram, sob o ponto de vista do crescimento do PIB, os mesmos cenários adotados, respectivamente, pelo Plano Nacional de Energia (PNE) 2030 (BRASIL 2007) e pela Matriz Energética do Estado de São Paulo (MEESP) 2035 (SÃO PAULO 2011). Porém, no lugar de suas denominações originais, esses cenários foram nomeados conforme mostrado na primeira coluna da Tabela 4.2, onde também são apresentadas as correspondentes taxas de crescimento dos cenários utilizados nessas projeções oficiais. No que tange ao rendimento da população e ao preço do diesel, com base nas variações observadas em anos recentes, foram adotados nas projeções ou que estes manteriam os mesmos valores de 2012 (cenário referência) ou variariam progressivamente até atingir $\pm 20 \%$ deste valor em 2020 . 

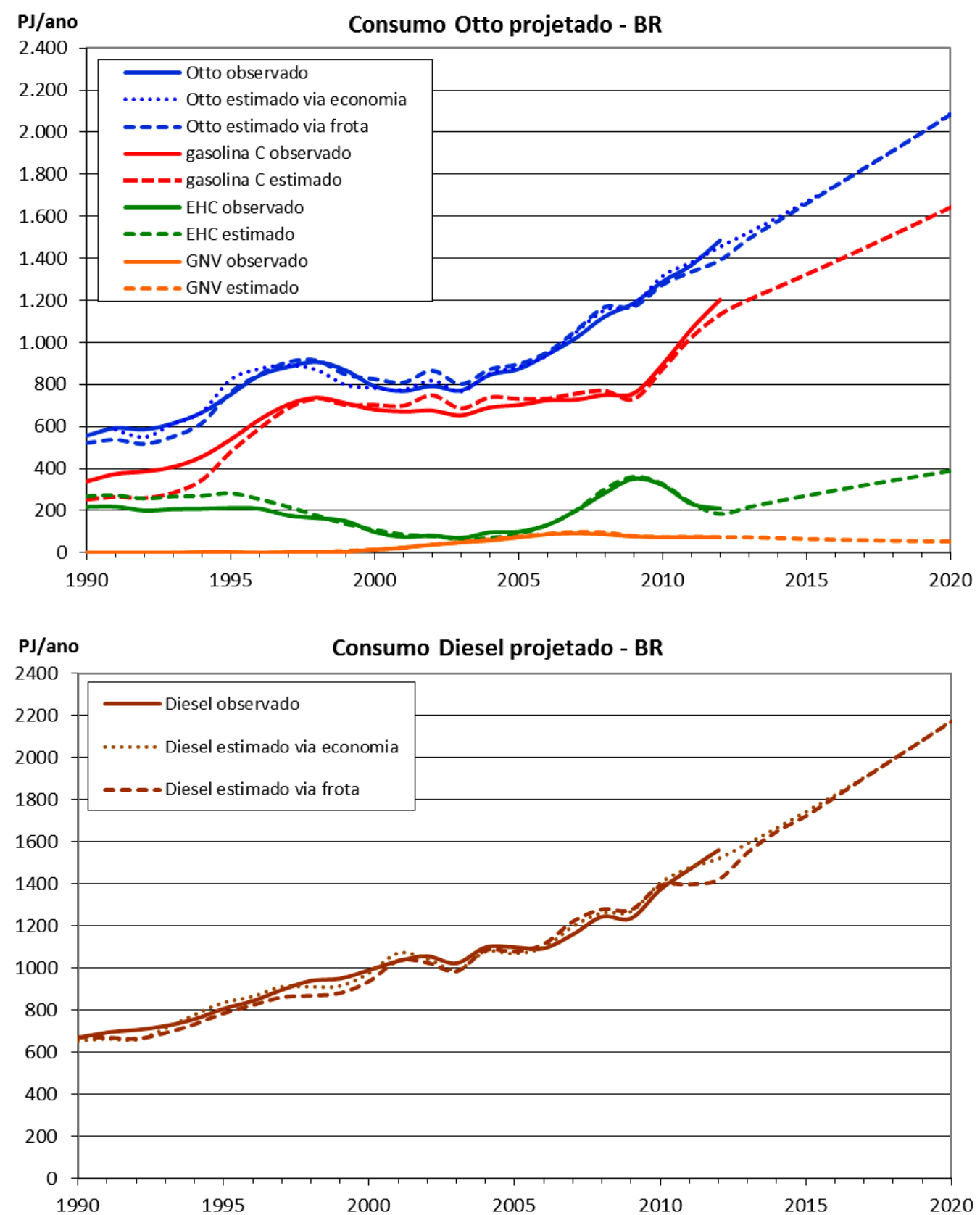

Ilustração 4.18 - Ajuste do modelo híbrido em função do modelo econométrico.

Fonte: Elaborado pelo autor, conforme descrito.

Tabela 4.2 - Crescimento relativo do PIB nos diversos cenários econômicos.

\begin{tabular}{ccc|cc}
\hline \multirow{2}{*}{ Cenário } & \multicolumn{2}{c|}{ PNE 2030 } & \multicolumn{2}{c}{ MEESP 2035 } \\
\cline { 2 - 5 } & denominação & tx. cresc. PIB & denominação & tx. cresc. PIB \\
\hline otimista & "na crista da onda" & $5,1 \%$ & 1 & $4,6 \%$ \\
referência & "surfando a marola" & $4,1 \%$ & base & $3,5 \%$ \\
médio & "pedalinho" & $3,2 \%$ & 2 & $2,9 \%$ \\
pessimista & "náufrago" & $2,2 \%$ & 3 & $2,1 \%$ \\
\hline
\end{tabular}

Fonte: Elaborado pelo autor, com base em dados do PNE 2030 e da MEESP 2035. 
Quanto às demais grandezas, exceto se indicado diferentemente, na constituição dos cenários foram mantidas as mesmas condições observadas em 2012, inclusive quanto à divisão de mercado dos combustíveis Otto, quando o preço do etanol manteve-se em torno de $70 \%$ do valor da gasolina C, o mesmo valor empregado no PNE 2030.

\subsection{Análise de sensibilidade}

Por ser a base das projeções, primeiro avaliou-se a sensibilidade dos modelos econométricos. A sensibilidade desses modelos às variações dos parâmetros econômicos identificados serem estatisticamente mais significativos para cada um dos consumos de combustíveis Otto e Diesel é apresentada, respectivamente, nas Ilustrações 4.19 e 4.20. À direita desses gráficos são exibidos os crescimentos dos consumos em relação ao observados em 2012 para cada cenário considerado. Como é possível verificar nessas ilustrações, os modelos econométricos isoladamente possibilitam prever nesses cenários que enquanto o crescimento do PIB em 2020 em relação a 2012 varia de $19 \%$ a 49\%, o crescimento do consumo Otto varia de cerca de $19 \%$ a $60 \%$, e do Diesel de cerca de $19 \%$ a $57 \%$. Se mantidas as atuais participações nas vendas de gasolina, etanol e GNV, esses crescimentos se refletirão na mesma proporção na emissão de $\mathrm{CO}_{2}$. As variações observadas para os casos limites são também uma indicação das incertezas dessas projeções.

\subsection{Aplicação dos modelos desenvolvidos para a projeção de alguns cenários}

A seguir, os modelos foram empregados para avaliar três situações que, em linhas gerais, respondiam aos objetivos inicialmente propostos. A saber: a expectativa de ganhos proporcionados pela evolução tecnológica, expressa pelas metas do programa Inovar-Auto ${ }^{111}$, e as perspectivas de redução das emissões de $\mathrm{CO}_{2}$ para atender a meta paulista da Política Estadual de Mudanças Climáticas $(P E M C)^{112}$ e de poluentes tóxicos em função do PROCONVE. É também apresentado um gráfico da evolução da participação dos segmentos da frota nos consumos de combustíveis Otto e Diesel, com o propósito de ilustrar o potencial do modelo para gerar informações que podem ser utilizadas para subsidiar a elaboração de políticas públicas e o planejamento estratégico das empresas.

\footnotetext{
111 Decreto no 7.819, de 3/10/2012, da Presidência da República. Disponível em <http://www.planalto. gov.br/ccivil_03/_ato2011-2014/2012/Decreto/D7819.htm>. Acessado em 18/09/2013.

112 Instituída pela Lei $\mathrm{n}^{\text {o }} 13.798$ de 09/11/2009. Disponível em <http://www.ambiente.sp.gov.br/wpcontent/uploads/2013/01/lei_13798_portugues.pdf>. Acessado em 19/9/2013.
} 

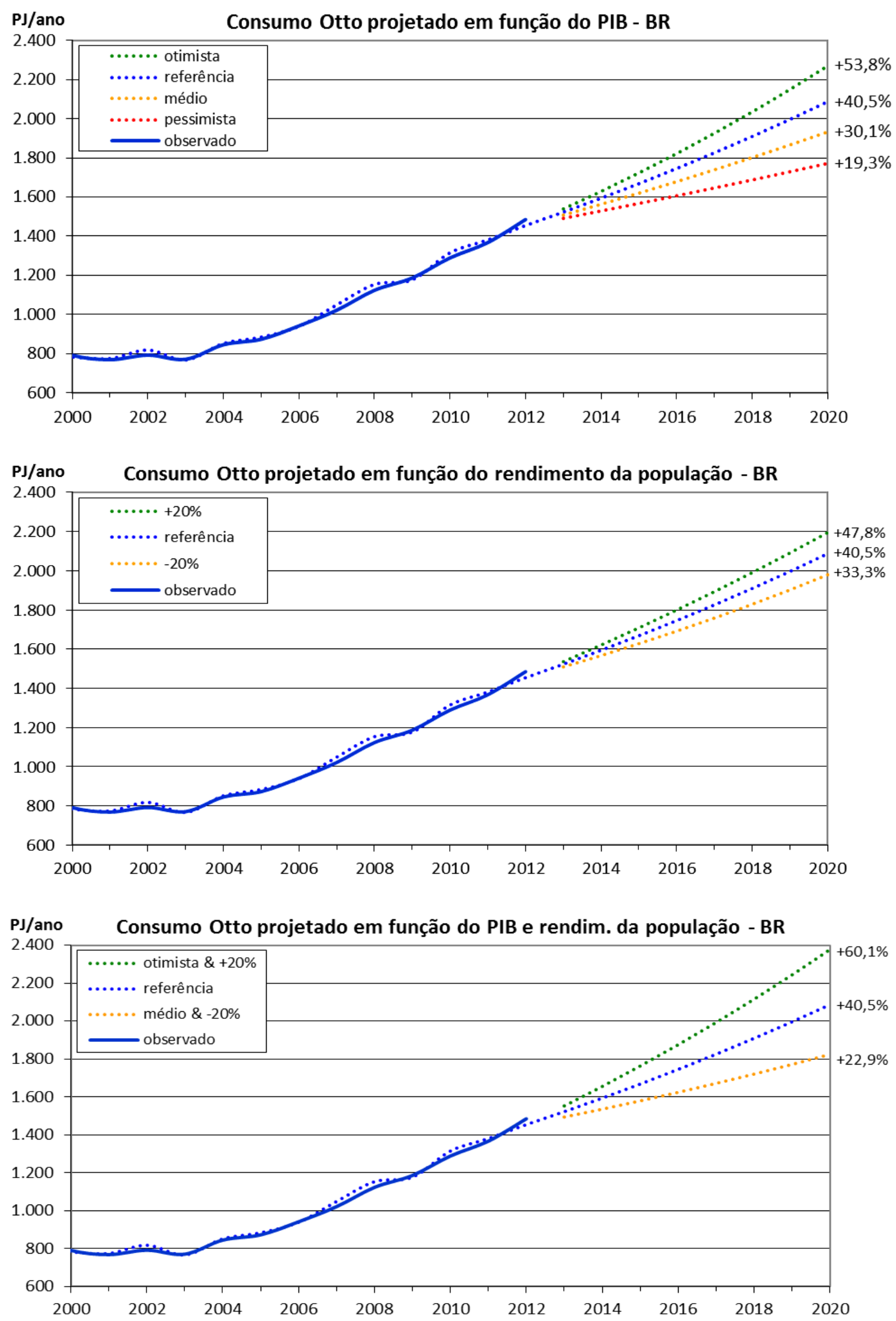

Ilustração 4.19 - Projeção da evolução do consumo Otto em função da economia.

Fonte: Elaborado pelo autor, conforme descrito. 

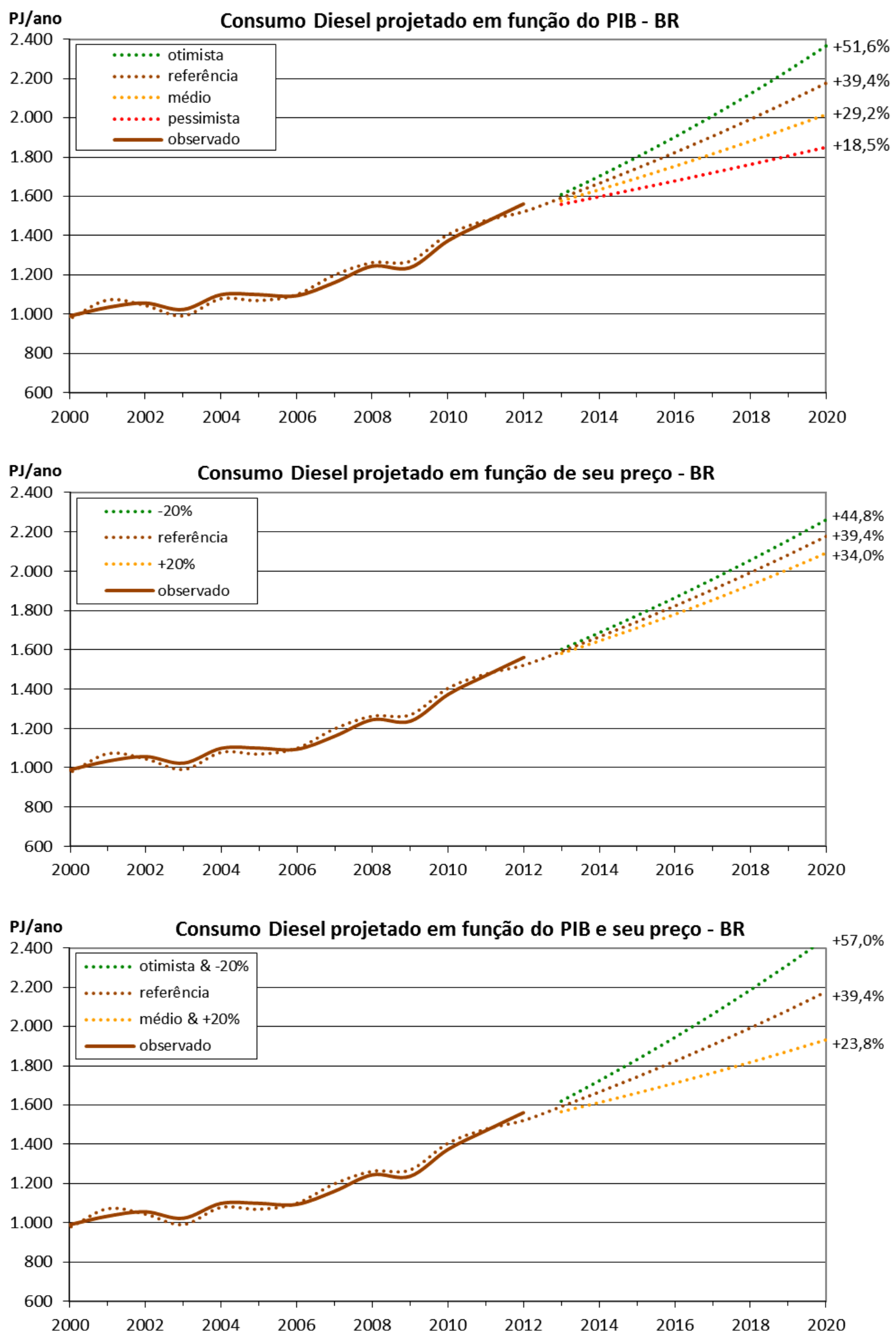

Ilustração 4.20 - Projeção da evolução do consumo Diesel em função da economia.

Fonte: Elaborado pelo autor, conforme descrito. 
Além dessas, outras situações que podem ser avaliadas pelo modelo são, por exemplo, o impacto da introdução de automóveis com motores ciclo Diesel ou de ônibus movidos a GNV. O limite dos cenários possíveis de serem simulados, em particular, pelo modelo híbrido depende se o que se deseja pode ser reproduzido pelos parâmetros incluídos nesse modelo.

Sob o ponto de vista da evolução tecnológica dos veículos leves, por meio do modelo híbrido é possível prever a redução do consumo do combustível Otto que as metas do programa InovarAuto, caso bem sucedido, proporcionará. Aplicando progressivamente as três metas de redução de consumo de veículos novos previstas nesse programa para 2017 , isto é, $12,08 \% ; 15,46 \%$ e $18,8 \%{ }^{113}$, as quais precisam ser mantidas até 2020, no cenário "referência" resultam nas reduções do consumo Otto totalizado indicados na Ilustração 4.21. Ou seja, se bem sucedido, as reduções de consumo que o programa Inovar-Auto proporcionará em relação ao consumo total projetado para 2020 no cenário "referência", serão da ordem de $6 \%$ a $9 \%$, conforme a meta alcançada.

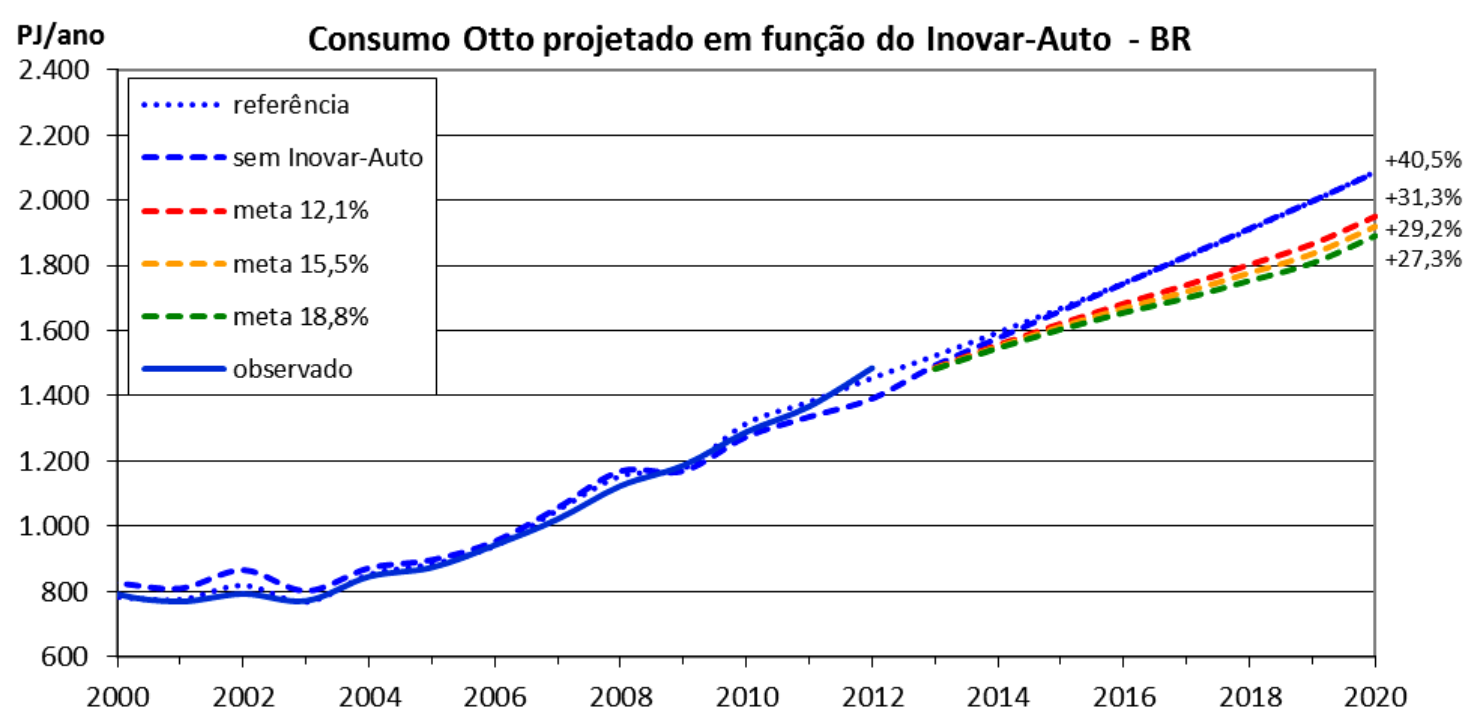

Ilustração 4.21 - Projeção da evolução do consumo em função das metas do Inovar-Auto.

Fonte: Elaborado pelo autor, conforme descrito.

Visando priorizar a ação sobre parcelas da frota, o modelo híbrido desenvolvido pode também identificar o quanto cada segmento da frota foi responsável pelo consumo de combustíveis, ou pela emissão de poluentes, e como essa participação evoluirá. Para as projeções a seguir utilizou-se o cenário "referência".

\footnotetext{
${ }^{113}$ Metas de ganhos de eficiência energética, expressos em autonomia (Km/l) ou em consumo energético $(\mathrm{MJ} / \mathrm{km})$, no Anexo II do Decreto n ${ }^{\circ} 7.819 / 2012$.
} 
A evolução da participação dos segmentos nos consumos de combustíveis Otto e Diesel nacionais é apresentada na Ilustração 4.22.
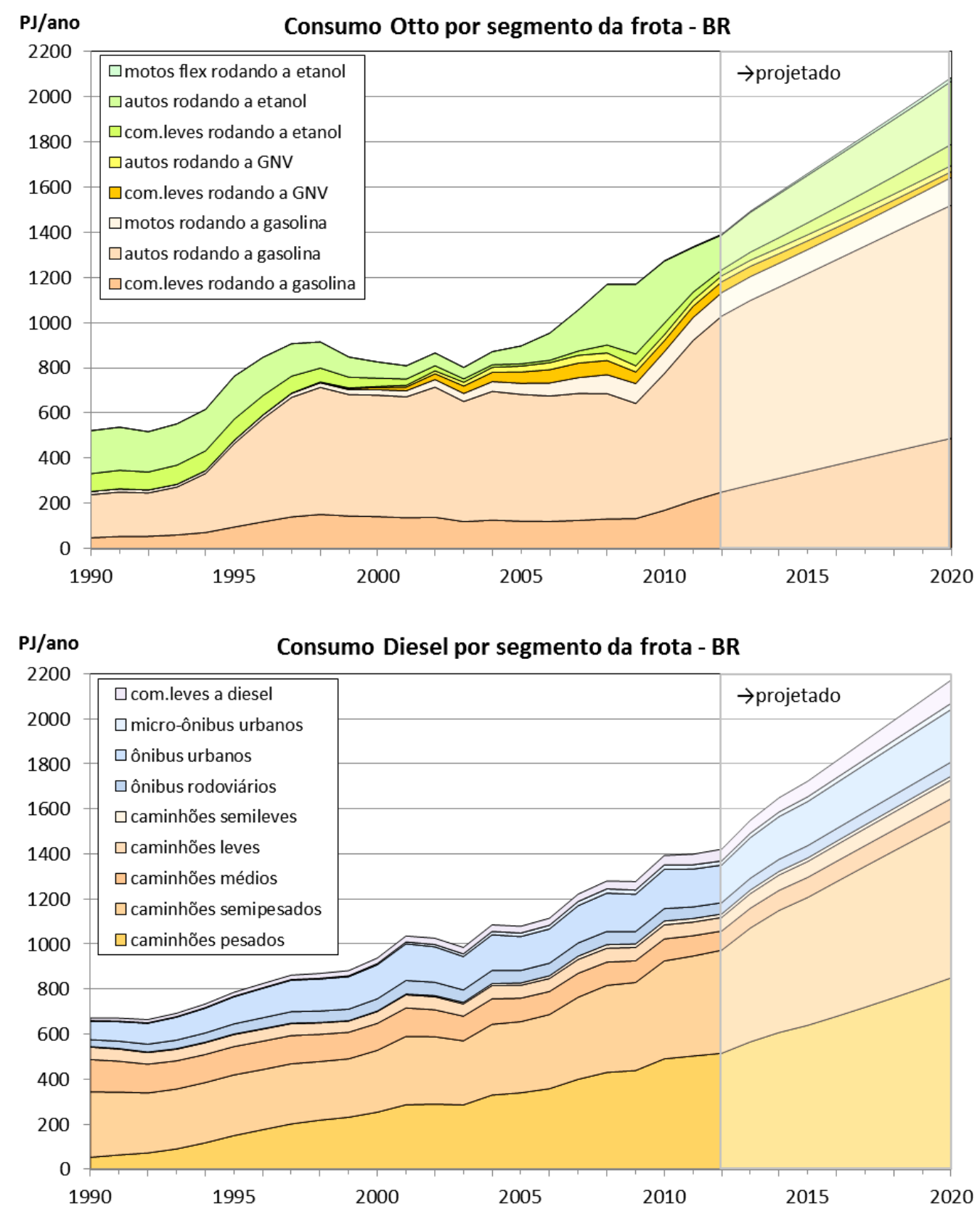

\section{Ilustração 4.22 - Projeção da evolução do consumo Otto e Diesel por classes.}

Fonte: Elaborado pelo autor, conforme descrito.

Destacam-se nesses gráficos a importância e o crescimento da participação dos segmentos automóveis e comerciais leves rodando a gasolina e dos caminhões semipesados e pesados.

Quanto às emissões, em função do controle e monitoramento existente e da legislação que estabelece meta de redução da emissão de $\mathrm{CO}_{2}$, preferiu-se avaliar as condições de São Paulo. Para tanto, foram utilizados os fatores de emissão de $\mathrm{CO}_{2}$ de cada combustível relacionados no 
BEESP. Os cálculos dessa emissão realizados nas planilhas correspondentes de cada segmento da frota foram consolidados na planilha "GEE", encontrada no CD em anexo.

A emissão de $\mathrm{CO}_{2}$ é avaliada segundo diferentes perspectivas. Primeiro será utilizada a abordagem do IPCC, que estabelece que a emissão do "tanque à roda" dos combustíveis renováveis é nula, e a emissão que ocorre para sua produção e distribuição, isto é, do "poço ao tanque", é contabilizada separadamente. Aplicando esse critério, a projeção segundo o cenário "referência", resulta no quadro mostrado na Ilustração 4.23. Como indicado nessa ilustração, em relação a 2005, ano estabelecido como referência para as metas da referida legislação estadual, em 2020 haverá um aumento da emissão de $\mathrm{CO}_{2}$ de $75 \%$, sendo 23,1 milhões de toneladas devidas ao combustível Otto, nesse contexto gasolina e GNV, e 32,2 milhões de toneladas devidas ao óleo diesel. Nessa ilustração é também possível visualizar a contribuição de cada segmento para essa emissão.

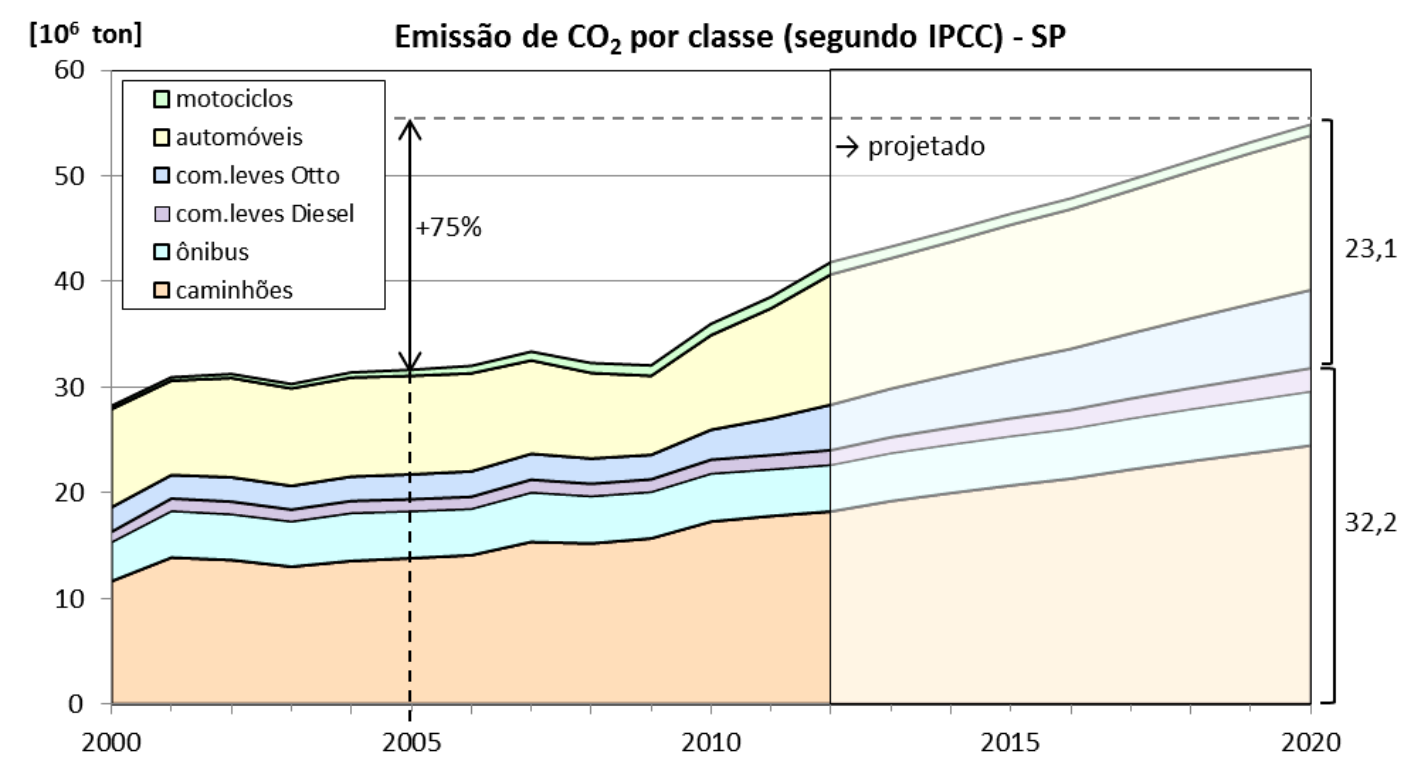

Ilustração 4.23 - Projeção da evolução da emissão de $\mathrm{CO}_{2}$ em São Paulo por classes.

Fonte: Elaborado pelo autor, conforme descrito.

Porém se vista em sua totalidade, isto é, do "poço à roda", a emissão de $\mathrm{CO}_{2}$ assume diferente proporções. Aqui são possíveis dois cenários: incluindo ou não a emissão devida às mudanças de uso da terra (LUC, sigla em inglês), discutidas no item 2.2.1.2 anterior. Para constituir esses cenários foram considerados os acréscimos relativos das emissões dos combustíveis renováveis indicadas na Tabela 2.4 desse item, que utiliza o ainda mais rigoroso acréscimo preconizado pela USEPA, considerando inclusive mudanças indiretas do uso da terra (ILUC, sigla em inglês). Além desses, foram também avaliados os cenários limítrofes: a eliminação do uso dos combustíveis renováveis (etanol e biodiesel); o sucesso do programa Inovar-Auto no 
cumprimento de sua meta mais básica; e a adoção de metas de redução de consumo mais arrojadas. Neste caso, supondo-se a adoção da meta de redução da Comunidade Europeia para veículos leves e de uma meta de redução de $1 \%$ ao ano para os veículos pesados, um valor médio aproximado das metas japonesas e estadunidense apresentadas nas Tabelas 2.12 e 2.13 anteriores. Para facilitar sua visualização, esses cenários considerando os programas de redução de consumo foram aplicados sobre o critério do IPCC.

Os resultados da projeção de todos esses cenários são apresentados na Ilustração 4.24. Como o resultado do modelo leva a crer, mantido o crescimento econômico, para os cenários considerados nem mesmo a adoção das metas mais arrojadas hoje existentes permitiria atingir à meta estabelecida pela referida legislação paulista, que é uma redução de $20 \%$ em 2020 em relação a 2005, caso esta meta valesse especificamente para o setor de transportes rodoviários. Para atingi-la designadamente nesse setor, outras medidas mais impactantes serão necessárias.

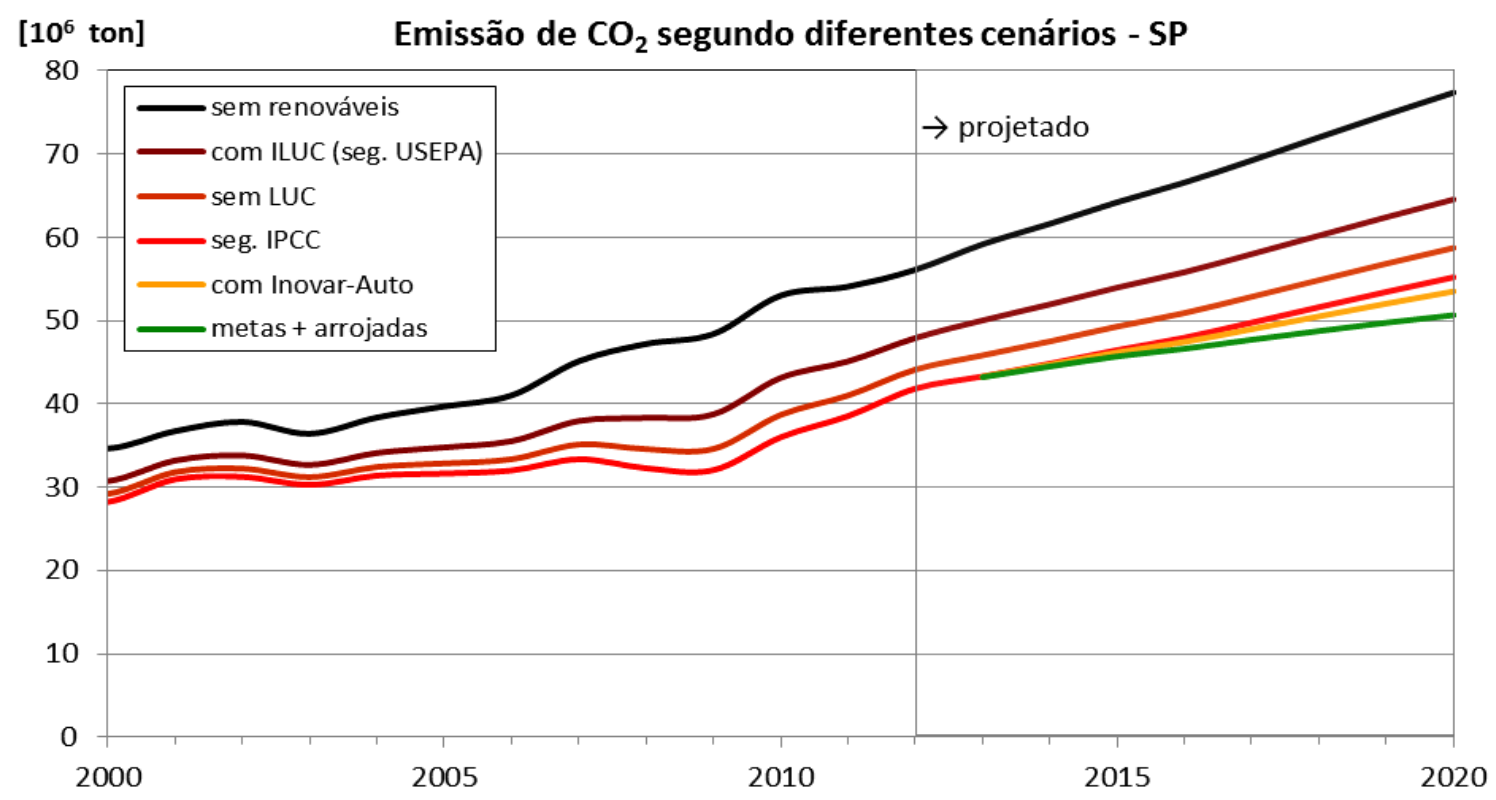

\begin{tabular}{|c|c|c|c|}
\hline \multirow{2}{*}{ Cenário } & \multicolumn{2}{|c|}{ Emissão de $\mathbf{C O}_{2}\left[10^{6}\right.$ ton $]$} & \multirow{2}{*}{$\begin{array}{c}\text { Crescimento em } \\
\text { relação a } 2005\end{array}$} \\
\hline & Otto & Diesel & \\
\hline sem renováveis & 43,5 & 33,9 & $95 \%$ \\
\hline com ILUC (seg. USEPA) & 31,0 & 33,5 & $86 \%$ \\
\hline sem LUC & 26,1 & 32,6 & $79 \%$ \\
\hline segundo IPCC & 23,1 & 32,2 & $75 \%$ \\
\hline com Inovar-Auto & 21,4 & 32,2 & $69 \%$ \\
\hline metas mais arrojadas & 19,8 & 30,9 & $60 \%$ \\
\hline
\end{tabular}

Ilustração 4.24 - Cenários da emissão de $\mathrm{CO}_{2}$ em São Paulo.

Fonte: Elaborado pelo autor, conforme descrito. 
Como mostrado na planilha "GEE", adicionando às emissões de $\mathrm{CO}_{2}$ a contribuição ao efeito estufa das emissões de $\mathrm{CH}_{4}$ e $\mathrm{N}_{2} \mathrm{O}$, em função dos fatores de emissão de empregados, resulta em emissões de $\mathrm{CO}_{2}$ equivalente cerca de $7 \%$ superiores às emissões de $\mathrm{CO}_{2}$ associadas ao combustível Otto, cerca de $1 \%$ associadas ao combustível Diesel, e na média cerca de 3,4\%. Esses resultados são da mesma ordem de grandeza, mas diferentes daqueles apresentados na Tabela 2.1, baseados em dados do "2006 IPCC Guidelines for National Greenhouse Gas Inventories". Mas como será discutido adiante, convém que esses fatores de emissão sejam reavaliados.

Quanto à evolução das emissões tóxicas, é preciso fazer a seguinte ressalva: há uma grande disparidade entre os fatores de emissão utilizados pelas diversas entidades que tratam dessa questão aqui no Brasil. Isso decorre do fato de não existirem dados adequados que possibilitem inferir as efetivas emissões dos veículos em uso. Já foram realizados alguns levantamentos experimentais dessa natureza, porém não em número nem com amostras com tamanhos suficientes para viabilizar esse propósito. Os procedimentos de inspeção veicular aqui empregados $^{114}$, a despeito de serem capazes de detectar falhas mais grosseiras, também não são apropriados para mensurar a deterioração dos sistemas de controle de emissões dos veículos.

Os inventários oficiais utilizam fatores de emissão baseados nos ensaios regulamentares, realizados, sobretudo, em veículos ou motores novos. Mas mesmo esses, muitas vezes não são obtidos segundo critérios uniformes. Conforme descrito no Relatório de Emissões Veiculares de 2012 da CETESB (2013), para motociclos ${ }^{115}$ e veículos leves grande parte dos dados foram calculados a partir de dados de ensaios de homologação, e a outra parte a partir dos dados de ensaios de controle de produção realizados pelos próprios fabricantes ${ }^{116}$, ambos ponderados pelo respectivo número de veículos vendidos relatados.

No caso dos veículos pesados, os fatores de emissão foram obtidos a partir dos dados de ensaios de controle de produção realizados em motores, originalmente em $\mathrm{g} / \mathrm{kWh}$, convertidos

\footnotetext{
${ }^{114}$ Durante a inspeção, mede-se dos veículos leves somente as emissões tóxicas de CO e HC em marcha lenta e a $2500 \mathrm{rpm}$ sem carga, condição esta que é muitas vezes denominada "marcha lenta acelerada". Nos veículos pesados, apesar do procedimento implicar em algum carregamento do motor, mede-se somente a emissão de fuligem durante a aceleração do motor com o veículo parado.

${ }^{115}$ Por representarem cerca de $88 \%$ do total, foram utilizados os dados dos motociclos com até $150 \mathrm{cc}$.

${ }^{116}$ Os resultados do controle de produção são relatados ao IBAMA por meio dos Relatórios de Valores de Emissão de Produção (RVEP). São avaliados de $0,1 \%$ a $0,4 \%$ dos veículos produzidos. O conjunto dos RVEPs gera cerca de 10 mil ensaios por ano. Os fatores derivados dos REVPs começaram a ser aplicados a partir de 2011 para os veículos leves e de 2012 para os motociclos.
} 
para $\mathrm{g} / \mathrm{km}$ com base na relação das emissões específicas pelo consumo específico, também em $\mathrm{g} / \mathrm{kWh}$; na densidade do óleo diesel e na eficiência média da classe do veículo pesado correspondente, em $\mathrm{km} / \mathrm{l}$, ponderados pelo respectivo número de veículos vendidos onde os motores foram aplicados.

Frequentemente, o fator de emissão de interesse para inventários é expresso como a multiplicação do fator de emissão do veículo novo por um fator de deterioração. Especificamente para os veículos leves, o $1^{\circ}$ Inventário do MMA e o último relatório da CETESB mencionam o uso de um fator de deterioração derivado de ensaios de controle de produção configurados para avaliar a durabilidade dos sistemas de controle de emissões. Ressalve-se, porém, que esses veículos ensaiados tipicamente "percorrem" os 80.000 km prescritos em um dinamômetro de chassi, nas dependências das montadoras, sob condições significativamente diferentes daquelas que podem ser observadas no mundo real.

Consequentemente, mesmo empregando a melhor informação disponível, que é a do último relatório da CETESB, em face da fragilidade desses dados, considera-se que a evolução das emissões tóxicas apresentadas a seguir serve, sobretudo, para ilustrar a capacidade do modelo para prever esse tipo de emissão. Rigorosamente, somente será possível conseguir resultados estatisticamente robustos sobre essa questão caso se obtenha dados consistentes sobre a emissão da frota em circulação.

Foram calculadas as emissões tóxicas somente de São Paulo para o cenário de referência. Para melhor representar a realidade, quando disponíveis, foram utilizados os fatores de emissão deteriorados. Alguns fatores empregados derivam da literatura internacional, como por exemplo, a emissão de $\mathrm{CH}_{4}$ e $\mathrm{N}_{2} \mathrm{O}$ dos veículos a diesel. Algumas lacunas foram preenchidas com os fatores de veículos equivalentes e, para as novas fases do PROCONVE, por fatores proporcionais aos limites da nova fase em relação à fase anterior. Quando não disponíveis separadamente, como no caso dos motociclos, assumiu-se que a emissão de hidrocarbonetos não metano (NMHC) é igual à emissão de hidrocarbonetos totais (HC). Por não estarem relacionadas com VKTs, as emissões evaporativas não foram consideradas, mas podem ser facilmente incluídas no modelo. Os fatores empregados pela CETESB e os utilizados para este estudo encontram-se na planilha "FEs"; e os resultados foram consolidados na planilha "Toxicos", ambas contidas no CD em anexo.

Os resultados da aplicação do modelo nas condições descritas são apresentados nas ilustrações a seguir. 

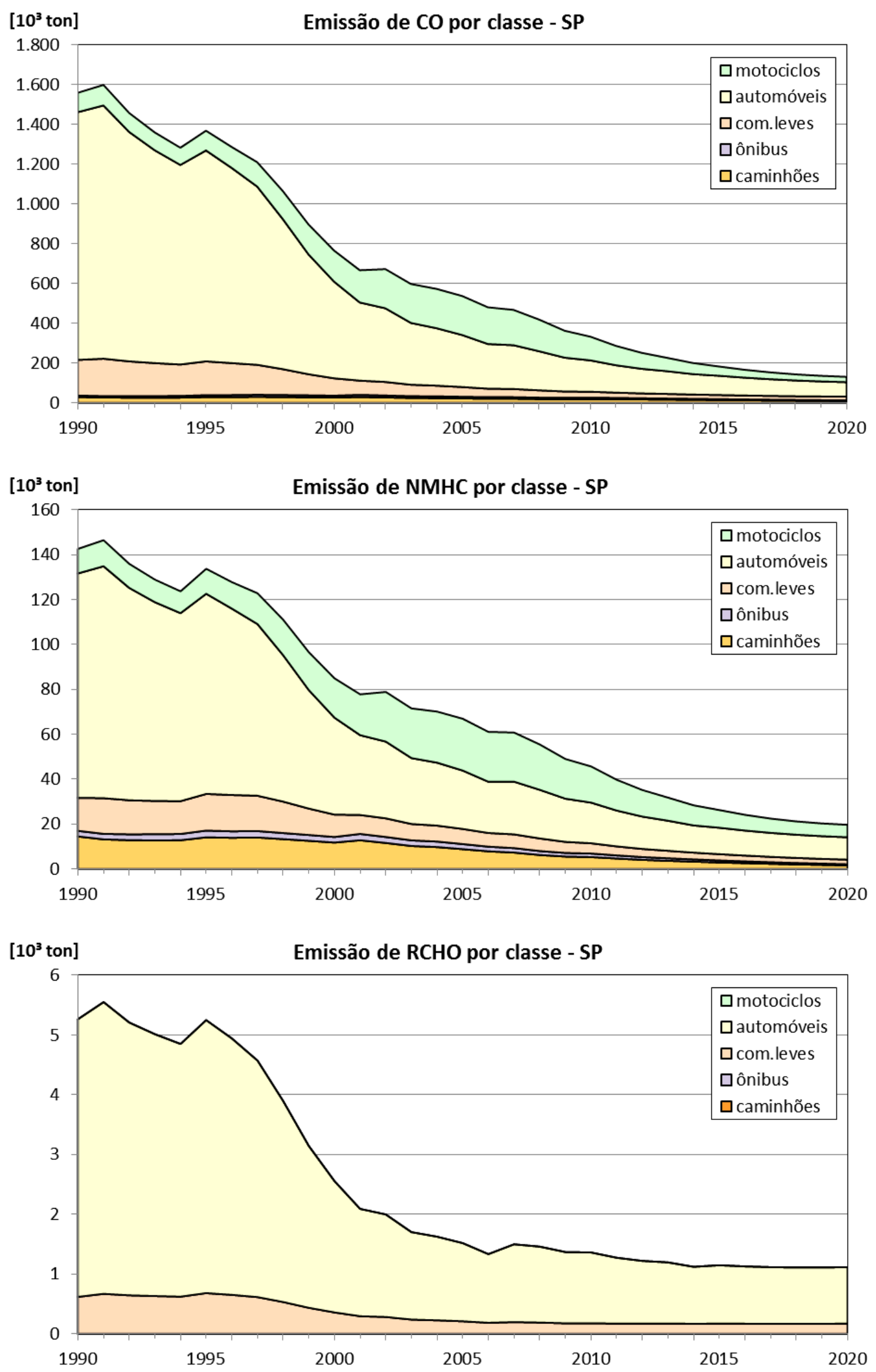

Ilustração 4.25 - Evolução das emissões predominantemente Otto em São Paulo.

Fonte: Elaborado pelo autor, conforme descrito. 

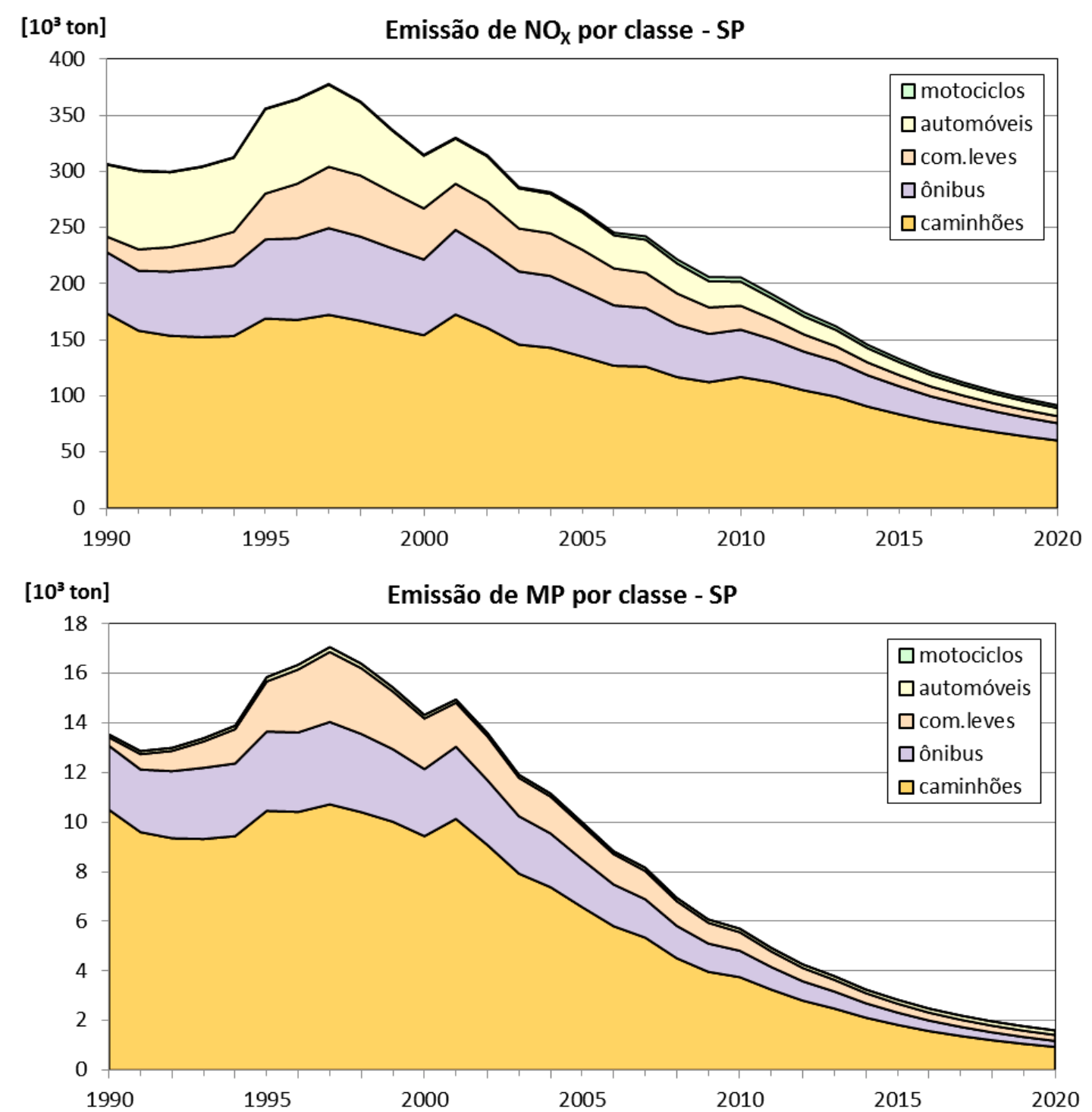

Ilustração 4.26 - Evolução das emissões predominantemente Diesel em São Paulo.

Fonte: Elaborado pelo autor, conforme descrito.

Destacam-se nesses gráficos:

- A manutenção da predominância das contribuições dos veículos leves às emissões de CO, $\mathrm{HC}$ e aldeídos (RCHO); e dos veículos a diesel às emissões de $\mathrm{NO}_{\mathrm{X}} \mathrm{e} \mathrm{MP}$.

- O expressivo crescimento relativo das emissões dos motociclos, sobretudo de HC, a partir dos anos 2000, o que indica a necessidade de se dar maior atenção a esse segmento.

- Um decréscimo expressivo ao longo do tempo e a manutenção dessa tendência nos anos vindouros de quase todos os poluentes, à exceção dos aldeídos (RCHO).

No entanto, com relação a este último item é necessário lembrar as limitações do modelo, nesse caso principalmente a fragilidade dos fatores de emissão empregados. 
É, em geral, muito difícil vincular esses resultados diretamente à evolução dos parâmetros de qualidade do ar monitorados pela CETESB, porque estes podem ser afetados por outras fontes de poluição, pelas condições atmosféricas (ex. vento, chuva e insolação) ou mesmo porque não se monitoram exatamente os mesmos compostos. Por exemplo, não se monitora a concentração de hidrocarbonetos, porém se monitora a concentração de ozônio, que é afetada por ela.

De qualquer forma, considerando que reconhecidamente as emissões nos grandes centros são predominantemente causadas por fontes móveis, espera-se que a evolução anual média das emissões calculadas apresente alguma correlação com os parâmetros de qualidade do ar. Com esse propósito foram confrontadas as evoluções das emissões calculadas com a dos parâmetros mais fortemente vinculados às fontes móveis, por meio das ilustrações a seguir.
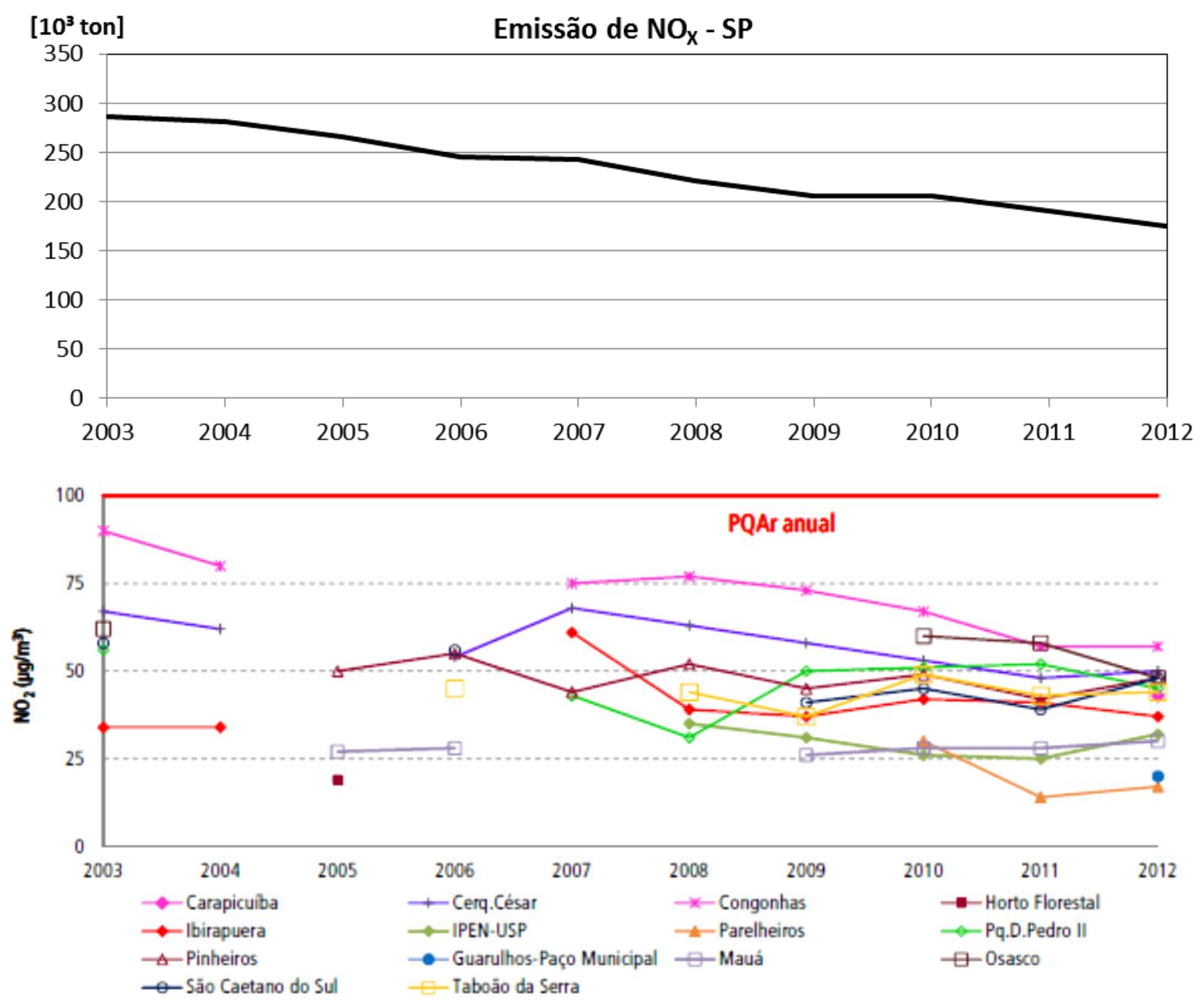

Ilustração 4.27 - Evolução da emissão calculada de $\mathrm{NO}_{\mathrm{X}}$ veicular e das concentrações medias anuais de $\mathrm{NO}_{2}$ em São Paulo.

Fonte: Gráfico elaborado pelo autor e Gráfico 22 do Relatório da Qualidade do Ar 2012 (CETESB 2013). 

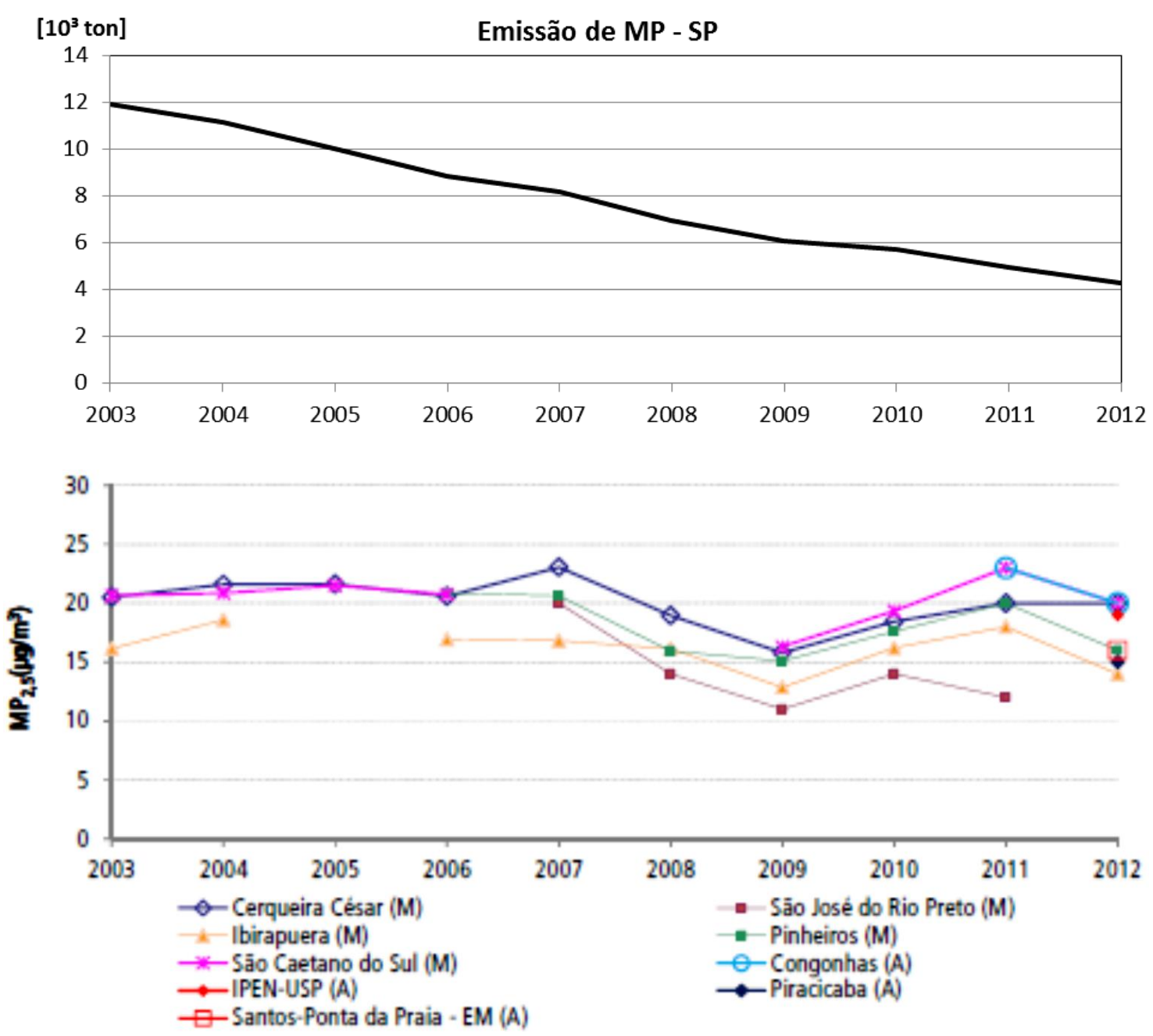

Ilustração 4.28 - Evolução da emissão calculada de MP veicular e das concentrações médias anuais de MPP 2,5 em São Paulo.

Fonte: Gráfico elaborado pelo autor e Gráfico 28 do Relatório da Qualidade do Ar 2012 (CETESB 2013).

Como pode ser observado nesses gráficos, há alguma correlação no caso dos óxidos de nitrogênio, mas essa correlação não se repete no caso do material particulado fino $\left(\mathrm{MP}_{2,5}\right)$, típico dos motores ciclo Diesel. Isso pode decorrer da existência de outras fontes poluidoras ou, se de fato comprovada que essa emissão é preponderantemente veicular, reforça a necessidade de se reavaliar os fatores de emissão empregados no modelo, principalmente para este poluente. 


\section{CONCLUSÕES E CONSIDERAÇÕES FINAIS}

Somente se precedidas de uma análise prévia sobre seus impactos, é possível elaborar políticas eficazes associadas ao transporte rodoviário. Para esse propósito, o objetivo deste trabalho foi o de desenvolver uma ferramenta nacional, estatisticamente consistente, de prognóstico do consumo de combustíveis e das emissões veiculares.

Visando identificar os aspectos relacionados à questão que deveriam ser considerados, esse desenvolvimento iniciou-se pelo levantamento dos cenários tendenciais e alternativas que estão sendo propostas, relativos a combustíveis, tecnologia veicular e sistemas de transportes. Apesar de não diretamente relacionados à ferramenta propriamente dita, para o propósito mais geral deste trabalho, desse levantamento derivam também alguns elementos contextuais importantes que convém sejam levados em consideração nas projeções que serão realizadas no país.

Induzida pelas relativamente recentes e rigorosas legislações dos países desenvolvidos que visam mitigar a emissão de GEE, a tecnologia veicular está passando por um acelerado processo evolutivo. Como relatado anteriormente, isto vem ocorrendo em diversas frentes. Mas o impacto dessa evolução pode ser resumido nas metas de redução de consumo, ou de emissão de $\mathrm{CO}_{2}$, estabelecidas nessas legislações, que diferem significativamente de região para região. No caso brasileiro, as metas foram definidas no programa federal Inovar-Auto. Ressalte-se, no entanto, que em grande parte, essas legislações se aplicam a veículos leves. Para veículos pesados, a situação é significativamente mais complexa e as poucas legislações existentes têm diferenças ainda mais significativas. A difusão de novas tecnologias veiculares, como a elétrica, ainda depende de incentivos governamentais para que possam se tornar competitivas. Especialistas do setor preveem para o mercado brasileiro até 2020 progressos, sobretudo, na tecnologia dos motores de combustão e das transmissões. Durante esse período, as novas tecnologias provavelmente devem ter aqui uma participação somente marginal.

Apesar do combate à mudança climática, instituições como a EIA prognosticam que o uso de combustíveis fósseis continuará a crescer por mais duas ou três décadas, induzido principalmente pelo setor de transporte e pelos países emergentes. Nesse período, seu preço deve sofrer alguma elevação, mas não a ponto disso comprometer seu uso. Contribuirá para esse processo, o desenvolvimento de fontes fósseis alternativas, como o GNV e o óleo extraído de rochas (folhelho ou xisto) e de areias betuminosas. Isso vem acontecendo em uma escala tão significativa que, inclusive, projeta-se a possibilidade que os Estados Unidos se tornem exportador de petróleo a partir de 2030. 
Nos últimos cinco anos, o uso de biocombustíveis recuou em função de fatores conjunturais como a estabilização do preço do petróleo ao redor de US\$ 100/bbl e o atual contexto econômico global desfavorável. Pesaram também os questionamentos sobre seus reais benefícios para reduzir a emissão de GEE, o possível impacto negativo que eles causaram nos preços dos alimentos e a dificuldade de viabilizar economicamente o etanol de segunda geração nos EUA. Apesar do atual recuo, a IEA prevê que os biocombustíveis retomarão seu crescimento para prover o mercado de combustíveis veiculares, devendo sua participação, desde que os biocombustíveis de segunda geração alcancem sua maturidade econômica, crescer dos atuais cerca de $2 \%$ para aproximadamente $5 \%$.

Em função da expressiva participação do etanol e, secundariamente, do biodiesel, no que tange aos biocombustíveis, o Brasil vive obviamente uma situação particular. Apesar do potencial, seja pelas barreiras impostas seja pelas próprias dificuldades que o país tem para se adequar para suprir o mercado externo, o principal mercado de nossos biocombustíveis possivelmente continuará a ser o interno. Porém, sua manutenção depende de que o governo brasileiro assegure que o acelerado desenvolvimento da tecnologia veicular que está ocorrendo, sobretudo, nos países desenvolvidos, também contemple nossos biocombustíveis. De qualquer forma, no momento, não parece que haverá mudanças muito expressivas no mercado nacional de biocombustíveis até 2020 .

Em paralelo a tudo isso, há também a intenção dos governos brasileiros, expressos no Plano Nacional de Logística e Transportes (PNLT) federal e no Plano Diretor de Desenvolvimento de Transportes (PDDT) paulista, em migrar de forma significativa o transporte de carga do modal rodoviário para os modais ferroviário e hidroviário. Assim como, sobretudo em função dos crescentes congestionamentos observados nas grandes cidades brasileiras, há o interesse em promover o transporte público de passageiros. Por outro lado, contrapondo-se a essas iniciativas, os governos continuam incentivando à indústria automobilística. Consequentemente, é difícil hoje vislumbrar como essas medidas, aparentemente antagônicas, de fato impactarão no transporte rodoviário nacional.

O segundo passo no desenvolvimento da ferramenta objeto deste trabalho foi rever e avaliar o que dos principais modelos disponíveis, estrangeiros ou nacionais, poderia ser aproveitado para esse propósito. Infelizmente, a conclusão foi que a falta de dados estatísticos e experimentais adequados inviabilizam o uso direto destes para esse fim. Em função dessa realidade, e apesar dos limites impostos pela disponibilidade de dados, constatou-se que seria necessário adotar uma abordagem diferenciada para se conseguir realizar essas projeções. 
Primeiro foi desenvolvido um conjunto de planilhas integrando todos os dados e cálculos de um modelo "bottom-up" similar ao utilizado nos inventários de emissões tóxicas nacionais, totalmente interconectadas e configuradas para facilitar, por meio de um processo iterativo, o ajuste fino das estimativas mais incertas, de forma que os consumos de combustíveis totalizados resultantes dessa ferramenta convergissem tanto quanto possível rapidamente para os consumos observados no país.

A seguir, visando possibilitar a predição dos consumos totalizados de combustíveis, foram elaborados, por meio de regressão linear, alguns modelos econométricos. Em função das informações disponíveis, realizou-se essa tarefa para dois contextos: o brasileiro e o paulista. Os indicadores econômicos identificados pertinentes foram: PIB, rendimento da população e preço para os combustíveis Otto (gasolina C, etanol e GNV); e PIB e preço para o óleo diesel ou biodiesel, depois que este foi introduzido. Apesar de algumas lacunas, inconsistências e incompatibilidades entre diferentes tabelas de dados, inclusive de mesma fonte, esses modelos demostraram ser estatisticamente robustos. Por meio da análise de sensibilidade à variação dos parâmetros econômicos também se obteve uma indicação das incertezas desses modelos na realização de projeções. Sob algumas condições, os resultados dos modelos econométricos podem ser convertidos, por meio de modelos "top-down", em emissões de $\mathrm{CO}_{2}$. A mesma técnica empregada no desenvolvimento desses modelos econométricos pode também ser utilizada para outros contextos e também para, visando refiná-los, neles eventualmente incluir novos parâmetros econômicos.

Entretanto, os resultados globais dos modelos econométricos não servem para analisar detalhes vinculados às características da frota ou para aferir demais emissões. Para tanto, é necessário inventariar e prognosticar o consumo de combustíveis e as emissões veiculares segregadas por suas classes. Para esse fim, foi desenvolvida uma técnica para incorporar os modelos econométricos na ferramenta baseada no modelo "bottom-up", resultando um modelo híbrido. Este modelo reproduz a realidade de uma forma significativamente melhor e demostrou ser estatisticamente robusto. Este técnica também permite que as projeções dos consumos de combustíveis obtidas por meio dos modelos econométricos balizem as projeções realizadas por meio do modelo híbrido. Ressalve-se, no entanto, que o cômputo dos resultados segregados para a gasolina $\mathrm{C}$, o etanol e o GNV nas projeções depende de se estimar suas futuras participações no mercado. Para esse propósito, conviria agregar ao trabalho as correspondentes curvas de elasticidade em função do preço. 
Mas como nos modelos oficiais, alguns resultados esbarram nas limitações impostas pela falta de dados estatísticos e experimentais. Esse é o caso, por exemplo, dos dados relativos às emissões tóxicas. Os fatores de emissões, isto é, as emissões médias dos veículos, atualmente disponíveis, quando não provenientes de fontes estrangeiras, provem de medições realizadas em veículos novos durante o processo de homologação ou de controle de produção, ou, na melhor das hipóteses, de ensaios realizados para avaliar a durabilidade dos sistemas de controle de emissões, porém exclusivamente de veículos leves, limitados aos oitenta mil quilômetros prescritos por lei, acumulados em condições controladas, nas dependências dos fabricantes. Apesar de como hoje configurado, o modelo híbrido permitir que se façam avaliações comparativas e, consequentemente, possibilite o ajuizamento sobre alguns aspectos associados à questão, para propósitos mais específicos, como por exemplo, subsidiar os modelos atmosféricos de formação e dispersão de poluentes, é necessário obter dados que melhor retratem a realidade. Para tanto, é imprescindível realizar campanhas para medir as emissões reais dos veículos em uso em uma amostra representativa da frota nacional.

A aplicabilidade dos modelos foi verificada pela avaliação dos seguintes cenários: a expectativa de ganhos proporcionados pela evolução tecnológica, expressa pelas metas do programa Inovar-Auto; e as perspectivas de redução das emissões de $\mathrm{CO}_{2}$ para atender a meta paulista da Política Estadual de Mudanças Climáticas (PEMC) e de poluentes tóxicos em função do PROCONVE. Os resultados dessas avaliações estão descritas no item 4.7 anterior. Além desses, diversos outros cenários podem ser avaliados. Por exemplo, o impacto da recente política de manutenção do preço da gasolina $\mathrm{C}$ na emissão de $\mathrm{CO}_{2}$, o impacto da liberação da comercialização de automóveis com motores ciclo Diesel. Novas situações podem requerer alguma adaptação dos modelos. Porém, qualquer alteração introduzida precisa ser feita com bastante critério, visando assegurar que ela não conduza a alguma incompatibilidade com as premissas e os cálculos embutidos, sobretudo, no modelo híbrido.

Além disso, para que os modelos mantenham sua utilidade, eles precisarão ser continuamente atualizados e revistos à medida que se obtenham novas ou mais consistentes informações. Visando o aperfeiçoamento dos modelos econométricos, devem-se testar, segundo os critérios estatísticos usados na análise de regressão múltipla, novos parâmetros econômicos que possam ser a eles incorporados. Em função da fragilidade de alguns dados empregados, o modelo híbrido não pode ser considerado um produto acabado. Para que o modelo híbrido seja preciso o suficiente de forma a que ele não conduza a falsas conclusões, é preciso que se façam levantamentos estatísticos e experimentais sobre seus dados menos robustos, por exemplo, os 
fatores de emissões tóxicas, de $\mathrm{CH}_{4}$ e $\mathrm{N}_{2} \mathrm{O}$. Não importa se em um primeiro momento a inclusão de novos dados, mais consistentes, impliquem em resultados de consumo de combustível do modelo diferentes dos resultados observados. Os outros parâmetros devem ser reajustados para eliminar essa diferença. Por meio desse processo iterativo, o modelo convergirá para melhor retratar a realidade. Conviria também verificar se, por meio do modelo híbrido seria possível levantar curvas de elasticidade em função do preço mais robustas dos combustíveis Otto, e incluir essa informação para avaliar o impacto da política de preços dos combustíveis.

Concluindo, as mais importantes contribuições desse trabalho foram estabelecer as bases de modelos econométricos que possibilitam prognosticar consistentemente o consumo energético do setor rodoviário nacional, e a nova técnica empregada na elaboração do modelo híbrido, que permite mais precisamente inventariar, segregar e projetar as emissões veiculares. Ambos os modelos demonstraram ser estatisticamente robustos e, portanto, adequados para a realização das projeções. Os modelos podem ser empregados para verificar os benefícios de algumas alternativas propostas, de forma a subsidiar estudos econômicos que possam identificar aquelas que apresentem as melhores relações custo-efetividade. As técnicas desenvolvidas, desde que os critérios e dados empregados sejam compatibilizados à realidade local, podem ser aplicadas a outras regiões, inclusive fora do Brasil. 


\section{REFERÊNCIAS}

BOND, Tami C. What is black carbon and where does it come from? In: INTERNATIONAL WORKSHOP ON BLACK CARBON IN LATIN AMERICA, 2009, México. Disponível em <http://www.theicct.org/sites/default/files/Bond-1.pdf>. Acesso em: 17 jan. 2013.

BOSTON CONSULTING GROUP. Powering autos to 2020: The era of the electric cars? Boston: EUA, 2011. Disponível em <http://www.bcg.com/documents/file80920.pdf>. Acesso em: 12 set. 2013.

BRAGA,V.; CASTILLO, R. Plano Diretor de Desenvolvimento dos Transportes (PDDT-vivo) e planejamento logístico de São Paulo. Mercator. Revista de Geografia da UFC, ano 5, $\mathrm{n}^{\circ} 10$, 2006. Disponível em <http://www.mercator.ufc.br/index.php/mercator/article/view/64/39>. Acesso em: 06 ago. 2013.

BRASIL. Instituto de Pesquisa Econômica Aplicada. Comunicados do IPEA n 137: Biodiesel no Brasil: desafios das políticas públicas para a dinamização. Brasília: Secretaria de Assuntos Estratégicos, 2012. Disponível em <http://www.ipea.gov.br/portal/images/ stories/PDFs/comunicado/120301_comunicadoipea137.pdf>. Acesso em: 09 ago. 2013.

BRASIL. Ministério da Agricultura, Pecuária e Abastecimento. Secretaria de Produção e Agroenergia. Plano Nacional de Agroenergia 2006-2011. $2^{\circ}$ ed. rev. Coordenadores Antônio Jorge de Oliveira e José Ramalho Brasília, DF: Embrapa Informação Tecnológica, 2006. 110 p. ISBN 85-7383-357-2.

BRASIL. Ministério de Ciência e Tecnologia. Primeiro inventário brasileiro de emissões antrópicas de gases de efeito estufa: emissões de gases de efeito estufa por fontes móveis, no setor energético. Brasília: MCT, 2006. Relatórios de Referência.

BRASIL. Ministério de Ciência e Tecnologia. Segundo inventário brasileiro de emissões antrópicas de gases de efeito estufa: emissões de gases de efeito estufa no transporte rodoviário. Brasília: MCT, 2010. Relatórios de Referência.

BRASIL. Ministério de Minas e Energia. Plano Nacional de Energia 2030 / Ministério de Minas e Energia; colaboração Empresa de Pesquisa Energética. Brasília: MME: EPE, 2007. 12 v. Disponível em <http://www.epe.gov.br/PNE/20080512_2.pdf>. Acesso em: 12 set. 2013.

BRASIL. Ministério do Meio Ambiente. $1^{\circ}$ inventário nacional de emissões atmosféricas por veículos automotores rodoviários: Relatório final. Brasília: MMA, 2011. Disponível em <http://www.mma.gov.br/estruturas/163/_publicacao/163_publicacao27072011055200. pdf $>$. Acesso em: 09 ago. 2013.

BRASIL. Secretaria de Tecnologia Industrial do Ministério da Indústria e Comércio. OVEG 1 - $1^{\text {a }}$ Reunião da comissão técnica. Brasília: MIC/STI, 1983. Relatórios de Ensaios de Campo.

CASTRO, C.F.C.; STRAMBI, O. Assessing the net effect on emissions of the implementation of a BRT system in Sao Paulo, Brazil: a case study and some hypothetical scenarios. In: TRANSPORTATION RESEARCH BOARD (TRB) OF THE NATIONAL RESEARCH COUNCIL TRB $89^{\mathrm{TH}}$ ANNUAL MEETING, Washington. Annual Meeting. Washington, 2010. CD-ROM. 
CAVAlETT, Otávio. Análise do ciclo de vida da soja. 2008, 221 p. Tese (Doutorado em Engenharia de Alimentos) da Faculdade de Engenharia de Alimentos da Universidade Estadual de Campinas, Campinas, 2008. Disponível em <http://www.unicamp.br/ fea/ortega/extensao/Tese-OtavioCavalett.pdf>. Acesso em: 12 mar. 2012.

COMPANHIA AMBIENTAL DO ESTADO DE SÃO PAULO. Emissões veiculares no estado de São Paulo 2012. São Paulo: CETESB, 2013. 108 p. (Série Relatórios / CETESB, ISSN 0103-4103).

Qualidade do ar no estado de São Paulo 2012. São Paulo: CETESB, 2013. 123 p. (Série Relatórios / CETESB, ISSN 0103-4103)

CUDDY, M.R.; WIPKE, K.B. Analysis of the fuel economy benefit of drivetrain hybridization. In: SAE INTERNATIONAL CONGRESS \& EXHIBITION, 1997, Detroit. Paper SAE 970289. Disponível em <http://www.nrel.gov/docs/legosti/fy97/22309.pdf>. Acesso em: 17 jan. 2013.

DAIMLER. Daimler Trucks North America celebrates the world premiere of "predictive cruise control". Louisville: Stuttgart, 2009. Disponível em <http://media.daimler.com/ dcmedia/0-921-899449-1-1193922-1-0-0-0-0-0-11701-614240-0-1-0-0-0-0-0.html>. Acesso em: 02 fev. 2012.

EMPRESA DE PESQUISA ENERGÉTICA (Brasil). Balanço Energético Nacional 2012: Ano base 2011 / Empresa de Pesquisa Energética. - Rio de Janeiro: EPE, 2012. Disponível em <https://ben.epe.gov.br/downloads/Resultados_Pre_BEN_2012.pdf>. Acesso em: 17 jan. 2013.

EUROPEAN COMMISSION. White paper: roadmap to a single European transport area towards a competitive and resource efficient transport system. Bruxelas, 2011. Disponível em <http://eur-lex.europa.eu/LexUriServ/LexUriServ.do?uri=COM:2011:0144:FIN:EN:PDF>. Acesso em: 17 jan. 2013.

EUROPEAN ENVIRONMENT AGENCY. Air pollutant emission inventory guidebook 2009: technical guidance to prepare national emission inventories. Copenhague: EEA, 2009. ISBN 978-92-9213-034-3, 2009. 21 p. (Cap. 1.A.3.b.i-iv Exhaust emissions from road transport). (Technical report series; $\mathrm{n}^{\mathrm{o}} 9$ 9). Disponível em $:<\mathrm{http} / / \mathrm{www}$.eea.europa.eu/ publications/emep-eea-emission-inventory-guidebook-2009>. Acesso em: 17 jan. 2013.

EUROPEAN FEDERATION FOR TRANSPORT AND ENVIRONMENT. How Clean Are Europe's Cars? An Analysis of Carmaker Progress Toward EU CO $\mathrm{O}_{2}$ Targets in 2010. Bruxelas, setembro de 2011, 27 p. Disponível em <http://www.transportenvironment. org/publications/how-clean-are-europes-cars-2011-edition>. Acesso em: 23 jan. 2012.

FAIDL, G. Market \& technology trends passenger car power train. In: AVL FUEL EFFICIENCE SEMINAR 2013, São Paulo. CD-ROM.

GLASER, B. et al. The 'Terra preta' phenomenon: a model for sustainable agriculture in the humid tropics. Naturwissenschaften 2001 jan 88, 37-41. Disponível em: <http://link.springer.com/content/pdf/10.1007\%2Fs001140000193>. Acesso em: 17 jan. 2013.

GREEN SEAL. Choose green report - low rolling resistance tires, 2003. Disponível em <http://www.wbdg.org/ccb/GREEN/REPORTS/cgrtirerollingresistance.pdf>. Acesso em 17 jul. 2013. 
HEYWOOD, J.B. Assessing the fuel consumption and GHG of future in-use vehicles. In: INTERNATIONAL CONFERENCE ON ENERGY AND SUSTAINABLE DEVELOPMENT: ISSUES AND STRATEGIES, 2010, Chiang Mai. Proceedings. Chiang Mai, 2010. Disponível em <http://esd2010.ueuo.com/esd2010cd/papers/S\%2001/S\%2001.2_ Assessing\%20the\%20Fuel\%20Consumption.pdf>. Acesso em: 03 fev. 2012.

INSTITUTO DE PESQUISA ECONÔMICA APLICADA. Biodiesel no Brasil: desafios das políticas públicas para a dinamização da produção. Comunicados do IPEA no 137 , de 1 de março de 2012. Governo Federal Secretaria de Assuntos Estratégicos da Presidência da República. Brasília, 2012. 21 p. Disponível em: < http://www.ipea.gov.br/portal/images/ stories/PDFs/comunicado/120301_comunicadoipea137.pdf>. Acesso em: 07 mar. 2012.

INSTITUTO DE PESQUISAS TECNOLÓGICAS. - Ensaios comparativos de ônibus urbanos. São Paulo, junho de 2007. Relatório Técnico nº. 91.377-205

INTERGOVERNMENTAL PANEL ON CLIMATE CHANGE. 2006 IPCC Guidelines for National Greenhouse Gas Inventories. Japan: IGES, 2006.

Climate Change 2007: synthesis report. Contribution of Working Groups I, II and III to the fourth assessment report of the Intergovernmental Panel on Climate Change. Genebra: IPCC, 2007. 104 p.

Climate Change 2007: the physical science basis. Contribution of Working Group I to the fourth assessment report of the Intergovernmental Panel on Climate Change. Cambridge: Cambridge University Press, ISBN 9780521 70596-7, 2007. 996 p. Disponível em: 〈http://ipcc-wg1.ucar.edu/wg1/Report/AR4WG1_Print_Ch02.pdf〉. Acesso em: 17 jan. 2013.

INTERNATIONAL COUNCIL ON CLEAN TRANSPORTATION. A policy-relevant summary of black carbon climate science and appropriate emission control strategies. Washington, 2009. 10 p. Disponível em: <http://www.theicct.org/sites/default/files/ publications/BCsummary_dec09.pdf $>$. Acesso em: 17 jan. 2013.

Global transportation energy and climate roadmap. Washington, 2012. 109 p. Disponível em: <http://www.theicct.org/global-transportation-energy-and-climate-roadmap>. Acesso em 17 jul. 2013.

INTERNATIONAL ENERGY AGENCY. Energy technologies perspectives: scenarios \& strategies to 2050. Paris: IEA PUBLICATIONS, 2010. 706 p. ISBN 978-92-64-08597-8.

From $1^{\text {st }}$ - to $2^{\text {nd }}$-generation biofuels technologies: an overview of current industry and RD\&D activities. Paris: IEA PUBLICATIONS, 2008.

Technology roadmap: electric and plug-in hybrid electric vehicles (EV/PHEV). Paris: IEA PUBLICATIONS, 2009. 47 p. Disponível em: <http:// www.oecd-ilibrary.org/ docserver/download/fulltext/6110211e.pdf?expires $=1323700580 \&$ id=id\&accname $=$ guest $\&$ che cksum=DA98D017CCE03749B4A1658B3A12785D>. Acesso em: 12 dez. 2011.

World Energy Outlook 2009. Paris: IEA PUBLICATIONS, 2009. 691p. ISBN 97892-6406-130-9.

World Energy Outlook 2010. Paris: IEA PUBLICATIONS, 2010. 731p. ISBN 97892-6408-624-1. 
INTERNATIONAL ENERGY AGENCY.World Energy Outlook 2011. Paris: IEA PUBLICATIONS, 2011.740p. ISBN 978-92-6412-414-1.

World Energy Outlook 2011: are we entering a golden age of gas? Special report. Paris: IEA PUBLICATIONS, 2011. 731p. ISBN 978-92-6408-624-1.

World Energy Outlook 2012. Paris: IEA PUBLICATIONS, 2012. 668 p. ISBN 97892-64-18084-0.

JONHSON et al. Processing of soot in an urban environment: case study from the Mexico City Metropolitan Area. Journal of the European Geosciences Union: Atmospheric Chemistry and Physics. SRef-ID: 1680-7324/acp/2005-5-3033. Disponível em < http://www.atmos-chemphys.net/5/3033/2005/acp-5-3033-2005.pdf>. Acesso em: 16 jan. 2013.

KELLER, G et al. Statistics For Management And Economics: a Systematic Approach. Belmont, CA: Wadsworth, 1988.

KODJAK, D. Global evolution of heavy-duty vehicle fuel economy and GHG regulations. Future Science, jun. 2011, vol. 2, no. 3, p. 245-260.

KWON, J.; ROUSSEAU, A.; SHARER, P. Analyzing the uncertainty in the fuel economy prediction for the EPA MOVES binning methodology. In: SAE WORLD CONGRESS \& EXHIBITION, 2007, Detroit. Paper SAE 2007-01-0280, ISBN 978-0-7680-1891-2 340.

MACEDO, I. S. et al. Greenhouse gas emissions in the production and use of ethanol in Brazil: present situation (2002). São Paulo: SMA, 2003.

NATIONAL RESEARCH COUNCIL. Modeling Mobile Source Emissions, Committee to Review EPA's Mobile Source Emissions Factor (MOBILE) Model, Board on Environmental Studies and Toxicology, Transportation Research Board of the National Research Council. Washington: National Academy Press, 2000. 258 p.

Tires and Passenger Vehicle Fuel Economy : informing Consumers, Improving Performance, TRB SPECIAL REPORT 286. Committee for the National Tire Efficiency Study, Transportation Research Board of the National Research Council. Washington: National Academy Press, 2006. 152 p. ISBN 0-309-09421-6. Disponível em: <http://www.energy.ca.gov/2006publications/TRB-1000-2006-001/TRB-1000-2006-001.pdf>. Acesso em: 17 jul. 2013.

Technologies and Approaches to Reducing the Fuel Consumption of Mediumand Heavy-Duty Vehicles, Committee to Assess Fuel Economy Technologies for Mediumand Heavy-Duty Vehicles, Transportation Research Board of the National Research Council. Washington: National Academy Press, 2010. 250 p. ISBN 978-0-309-14982-2. Disponível em: <http://www.nap.edu/catalog.php?record_id=12845\#description>. Acesso em: 17 jan. 2013.

NIGRO, F.E.B.; TRIELLI, M.A.; COSTA, C.M. Emission characteristics of a diesel engine operating with biodiesel and blends. In: SAE BRASIL, São Paulo, 2007. Paper SAE 2007-012635.

RAJAGOPALAN, A. et al. Development of Fuzzy Logic and Neural Network Control and Advanced Emissions Modeling for Parallel Hybrid Vehicles. National Renewable Energy Laboratory, 2003, NREL/SR-540-32919, Golden, EUA. Disponível em: <http://www.nrel.gov/ docs/fy04osti/32919.pdf>. Acesso em: 11 jul. 2013. 
RAMANA, M. V. et al. Warming influenced by the ratio of black carbon to sulphate and the black-carbon source. Nature Geoscience, 2010; DOI: 10.1038/ngeo918. Disponível em: <http://www.nature.com/ngeo/journal/v3/n8/abs/ngeo918.html>. Acesso em: 17 jan. 2013.

REFUEL PROJECT. Eyes on the track, mind on the horizon: from inconvenient rapeseed to clean wood: a European road map for biofuels. Holanda: Energy Research Centre of the Netherlands, 2008. Financiado pela Comissão Europeia dentro do Programa "Intelligent Energy - Europe".

SANTOS, E. M. dos. Por que promover uma maior utilização dos gases combustíveis no Estado de São Paulo? In: Workshop "Discussão de propostas para um Plano de Ação Governamental visando o desenvolvimento do mercado de gás natural no Estado de São Paulo decorrente das novas reservas da Bacia de Santos e do Pré-sal", 16 de novembro de 2010, São Paulo. Disponível em: <http://catedradogas.iee.usp.br/apres_worshop/ apres_catedra.pdf $>$. Acesso em: 16 mar. 2011.

SÃO PAULO (Estado). Secretaria de Energia. Balanço Energético do Estado de São Paulo 2012: Ano Base 2011. Secretaria de Energia - São Paulo, 2012. Disponível em <http://www.energia.sp.gov.br/a2sitebox/arquivos/documentos/386.pdf>. Acesso em: 17 jul. 2013.

Matriz Energética do Estado de São Paulo - 2035 - Sumário Executivo. Secretaria de Energia - São Paulo, 2011. Disponível em <http://www.energia.sp.gov.br/ a2sitebox/arquivos/documentos/45.pdf>. Acesso em: 12 set. 2013.

SCANIA. Scania Active Prediction: new cruise control saves fuel using GPS data. Press release P11Z01EN Per-Erik Nordström 02/12/2011 Disponível em <http://www.scania.com/ Images/P11Z01EN\%20Active\%20prediction_285940.pdf>. Acesso em: 02 fev. 2012.

SCHULTZE, C. The Electrification of the powertrain: pursuing multiple parallel paths. In: SIMEA, São Paulo: AEA, 2009. CD-ROM.

SHINDELL, D., et al. Climate, health, agricultural and economic impacts of tighter vehicleemission standards. Nature Climate Change n. 1, p.59-66, 2011 DOI: 10.1038/nclimate1066 Publicado "online" em 29 de março de 2011. Disponível em <http://www.nature.com/ nclimate/journal/v1/n1/full/nclimate1066.html>. Acesso em: 23 fev. 2012.

SWEDBERG, S. Fabricantes pressionam por graus de viscosidade mais baixos. Lubes em Foco, n. 25, p. 10-13, jun./jul. 2011. Traduzido por Pedro Nelson Belmiro.

THE WORLD BANK. Brazil Low-carbon - Country Case Study, Briefing Note 005/10 of the Energy Sector Management Assistance Program (ESMAP). Washington, D.C., 2010. Disponível em <http://wbi.worldbank.org/wbi/document/brazil-low-carbon-country-casestudy $>$. Acesso em 25 jul. 2013.

THIJSSEN, J.; LASHER, S. Analysis of fuel choices for fuel cell vehicles. Fuel Chemistry Division Preprints, 2002; no. 47(2), p. 667. Disponível em: <http://web.anl.gov/PCS/ acsfuel/preprint\%20archive/Files/47_2_Boston_10-02_0187.pdf>. Acesso em: 17 jan. 2013.

TIAX. European Union Greenhouse Gas Reduction Potential for Heavy-Duty Vehicles, Report TIAX Reference No. D5625, desenvolvido para The International Council on Clean Transportation. Cupertino, 2011. Disponível em <http://www.theicct.org/ghg-reductionpotential-heavy-duty-vehicles-eu>. Acesso em 25 jul. 2013. 
UNIVERSITY OF CALIFORNIA, SAN DIEGO. Black carbon pollution emerges as major player in global warming. Rockville, EUA, ScienceDaily, 24 de março de 2008. Disponível em: <http://www.sciencedaily.com/releases/2008/03/080323210225.htm>. Acesso em: $21 \mathrm{dez}$. 2010 .

UNITED NATIONS ENVIRONMENT PROGRAMME AND WORLD METEOROLOGICAL ORGANIZATION. Integrated assessment of black carbon and tropospheric ozone: summary for decision makers. 2011. Disponível em: <http:// www.unep.org/dewa/Portals/67/pdf/ Black_Carbon.pdf>. Acesso em: 27 fev. 2012.

UNIÃO DA INDÚSTRIA DA CANA DE AÇÚCAR. Setor sucroalcooleiro e a regulação do etanol. Apresentação realizada pelo presidente interino Antônio de Pádua Rodrigues. $13^{\circ}$ Encontro Internacional de Energia, FIESP, São Paulo, 07/08/2012. Disponível em <http://www.unica.com.br/download.php?idSecao=17\&id=24775593> e em <http://hotsite. fiesp.com.br/energia/apresentacoes/sala05/07.08/0830-ANTONIO-PADUA.pdf>. Acesso em: 24 jan. 2013.

UNITED STATES ENVIRONMENTAL PROTECTION AGENCY. Discussion Draft of Environmental Protection Agency Regulatory Impact Analysis. Washington, D.C., 2009.

EPA Staff Technical Report: Cost and Effectiveness Estimates of Technologies Used to Reduce Light-duty Vehicle Carbon Dioxide Emissions. Washington, D.C., 2008. Disponível em: <http://www.epa.gov/otaq/climate/420r08008.pdf>. Acesso em: 21 jul. 2013.

MOVES2010 Highway Vehicle Population and Activity Data. Washington, D.C., 2010. Disponível em: <http://www.epa.gov/otaq/models/moves/420r10026.pdf>. Acesso em: 15 ago. 2013.

- Renewable Fuels Standard Program (RFS2) Regulatory Impact Analysis. Washington, D.C., 2010. Disponível em: <http://www.epa.gov/oms/renewablefuels/ 420r10006.pdf>. Acesso em: 24 abr. 2012.

VILLANUEVA, Luz Zoraida Dondero. Uso de gás natural em veículos leves e Mecanismo de Desenvolvimento Limpo no contexto brasileiro. São Paulo, 2002, 163 p. Tese (Doutorado em Energia) do Programa Interunidades de Pós-Graduação em Energia, Universidade de São Paulo, 2002.

WALSH, Michael P. Strategies for black carbon controls in the transportation sector. International Workshop on Black Carbon in Latin America, Cidade do México, México, 19/10/2009. Disponível em <http://www.theicct.org/sites/default/files/Walsh_0.pdf>. Acesso em: 17 jan. 2013.

WORLD ECONOMIC FORUM. Repowering Transport. Genebra, 2011. Disponível em <http://www3.weforum.org/docs/WEF_RepoweringTransport_ProjectWhitePaper_2011.pdf>. Acesso em: 29 ago. 2012. 


\section{ANEXO A - REGRESSÃO E CORRELAÇÃO}

Fonte: Elaborado pelo autor com base no livro "Statistics for Managment and Economics"

\section{REGRESSÃO LINEAR SIMPLES}

\section{MÉTODO DOS MÍNIMOS QUADRADOS}

Consiste em minimizar a soma dos erros quadrados

$$
\begin{gathered}
S S E=\sum\left(y_{i}-\hat{y}_{i}\right)^{2} \\
y=\beta_{0}+\beta_{1} x+\varepsilon \\
\sum \mathrm{x}_{\mathrm{i}} ; \sum \mathrm{y}_{\mathrm{i}} ; \sum \mathrm{x}_{\mathrm{i}}^{2} ; \sum \mathrm{y}_{\mathrm{i}}^{2} \text { e } \sum \mathrm{x}_{\mathrm{i}} \mathrm{y}_{\mathrm{i}} \\
\bar{x}=\frac{\sum x_{i}}{n} \quad \text { e } \bar{y}=\frac{\sum y_{i}}{n}
\end{gathered}
$$

Isto é, dos resíduos $\varepsilon$ na equação

Na prática, para um conjunto de dados $\left(\mathrm{x}_{\mathrm{i}}, \mathrm{y}_{\mathrm{i}}\right)$, calcula-se

E a partir deles, os valores médios

As somas dos quadrados

$$
S S_{x}=\sum x_{i}^{2}-\frac{\left(\sum x_{i}\right)^{2}}{n} \text { e } S S_{x y}=\sum x_{i} y_{i}-\frac{\left(\sum x_{i}\right)\left(\sum y_{i}\right)}{n}
$$

(vide também $S S_{y}$ adiante)

E os estimadores do coeficiente angular $\widehat{\beta_{1}}=\frac{S S_{x y}}{S S_{x}}$ e da intersecção $\widehat{\beta_{0}}=\bar{y}-\widehat{\beta_{1}} \bar{x}$

Resultando na equação

$$
\hat{y}=\widehat{\beta_{0}}+\widehat{\beta_{1}} x
$$

Isto só é válido se:

a) A distribuição de probabilidade de $\varepsilon$ é normal.

b) A média da distribuição dos erros é zero, isto é, $\mathrm{E}(\varepsilon)=0$.

c) A variância de $\varepsilon(\operatorname{Var}(\varepsilon))$ é $\sigma_{\varepsilon}{ }^{2}$, a qual é constante e independente do valor de $\mathrm{x}$, porém desconhecida.

d) Os erros associados ao valor de quaisquer dois valores de y são independentes. Ou seja, o valor de $\varepsilon$ em um ponto não afeta $\mathrm{o} \varepsilon$ em outro ponto.

\section{AVALIAÇÃO DO MODELO}

É feito pelas seguintes três técnicas.

Estimando a variância $\sigma_{\varepsilon}^{2}$ da população (a raiz é o desvio padrão da população)

O estimador da variância da distribuição amostral é dado por

$$
s_{\varepsilon}^{2}=\frac{S S E}{n-2}
$$

Portanto, o erro padrão, estimador do desvio padrão da população, é $\quad S_{\varepsilon}=\sqrt{\frac{S S E}{n-2}}$

O valor de SSE pode ser obtido por meio de

$$
\begin{aligned}
& S S E=S S_{y}-\frac{S S_{x y}^{2}}{S S_{x}} \\
& S S_{y}=\sum y_{i}^{2}-\frac{\left(\sum y_{i}\right)^{2}}{n}
\end{aligned}
$$

Onde

Quanto menor o valor de $s_{\varepsilon}$ melhor foi o ajuste do modelo. Ele pode ser comparado como uma porcentagem, por exemplo, do valor médio $\bar{y}$. Melhor que para avaliar o ajuste, esta alternativa é mais útil para comparar o ajuste de diferentes modelos.

\section{Teste do coeficiente $\beta_{1}$ da correlação}

Existem três alternativas para avaliar se existe uma relação linear entre as variáveis:

a) Se se deseja avaliar se há alguma relação linear entre x e y, testa-se $\mathrm{H}_{\mathrm{A}}$ : $\beta_{l} \neq 0$ 
b) Se se deseja avaliar se relação linear é positiva, testa-se

$\mathrm{H}_{\mathrm{A}}: \beta_{1}>0$

c) Se se deseja avaliar se relação linear é negativa, testa-se

$\mathrm{H}_{\mathrm{A}}: \beta_{1}<0$

Em todos esses casos, a hipótese nula é

$\mathrm{H}_{0}: \beta_{1}=0$

A estatística de teste é

$$
t=\frac{\widehat{\beta_{1}}-\beta_{1}}{s_{\widehat{\beta_{1}}}} \text { onde } s_{\widehat{\beta_{1}}}=\frac{s_{\varepsilon}}{\sqrt{s s_{x}}}
$$

Como $\varepsilon$ é distribuída normalmente, a estatística de teste segue a distribuição $t$ de Student com (n-2) graus de liberdade. Portanto, se $|t|>t_{\alpha / 2, \mathrm{n}-2}$ rejeita-se a hipótese nula, ou seja, conclui-se que há relação linear entre as variáveis.

\section{Coeficiente de correlação e coeficiente de determinação}

\section{Coeficiente de correlação}

$\mathrm{O}$ coeficiente de correlação da população $\rho$ mede a similaridade das mudanças nos valores de $\mathrm{x}$ e y. Seu valor varia entre -1 a 1 . Se $\rho=0$ não há correlação entre as variáveis.

Seu estimador, o coeficiente de correlação da amostra $r$ é definido por $r=\frac{S S_{x y}}{\sqrt{S S_{x} \cdot S S_{y}}}$

Os valores de $r$ e $\widehat{\beta_{1}}$ sempre tem o mesmo sinal, e se um é zero, o outro também o será.

O coeficiente $r$ é avaliado por meio da seguinte hipótese nula $\quad H_{0}: \rho=0$

A estatística de teste é

$$
t=\frac{r-\rho}{s_{r}} \quad \text { onde } \quad s_{r}=\sqrt{\frac{1-r^{2}}{n-2}}
$$

A região de rejeição é dada novamente por

$$
|t|>t_{\alpha / 2, \mathrm{n}-2}
$$

\section{Coeficiente de determinação}

A variância de $\mathrm{y}$, isto é, a soma dos quadrados $\mathrm{SS}_{\mathrm{y}}$ tem uma parcela que é explicada pela regressão e uma outra que permanece inexplicada, a qual é caracterizada pela SSE.

Ou seja,

$$
S S_{y}=S S E+S S R
$$

A parcela explicada pela regressão, denominada soma dos quadrados da regressão (SSR) é dada por

$$
S S R=\sum\left(\widehat{y}_{l}-\bar{y}\right)^{2}
$$

O coeficiente de determinação é definido como o quadrado de $r$, ou seja, $r^{2}=\frac{S S_{x y}}{S S_{x} \cdot S S_{y}}$

Ou, manipulando algebricamente,

$$
r^{2}=\frac{S S_{y}-S S E}{S S_{y}}=\frac{S S R}{S S_{y}}
$$

\section{Intervalo de confiança ou de predição}

Para um determinado valor de $\mathrm{x}_{\mathrm{g}}$

$$
\hat{y}=\widehat{\beta_{0}}+\widehat{\beta_{1}} x_{g}
$$

O intervalo de predição é dado por

$$
\hat{y} \pm t_{\alpha / 2, n-2} \cdot s_{\varepsilon} \sqrt{1+\frac{1}{n}+\frac{\left(x_{g}-\bar{x}\right)^{2}}{S S_{x}}}
$$

Para um determinado valor de $\mathrm{x}$, o valor esperado de uma população com este valor de $\mathrm{x}$ é dado por

$$
\mathrm{E}(\mathrm{y})=\beta_{0}+\beta_{1} \mathrm{x}
$$

Nesse caso, o intervalo de confiança é dado por

$$
\hat{y} \pm t_{\alpha / 2, n-2} \cdot s_{\varepsilon} \sqrt{\frac{1}{n}+\frac{\left(x_{g}-\bar{x}\right)^{2}}{S S_{x}}}
$$

O intervalo de confiança é menor que o de predição. Isto é razoável porque é mais fácil estimar a média de uma população é mais fácil que prever um determinado valor em particular. 


\section{REGRESSÃO LINEAR MÚLTIPLA}

O objetivo da regressão linear múltipla é, pela inclusão de novas variáveis independentes, melhorar a capacidade de predição em relação àquela que é possível por meio de uma regressão linear simples, assim como eliminar a possibilidade de desconsiderar uma variável que também seja significativa. A esse processo de tentar incluir novas variáveis se denomina análise de regressão múltipla. Se bem sucedida, o erro padrão da estimativa será reduzido e os testes de significância produziram melhores resultados. Convém destacar que, no entanto, que há um preço para incluir essas novas variáveis, não somente pelo custo para obter novos dados, como também pela perda de graus de liberdade decorrente da introdução das variáveis adicionais, apesar de que esta perda pode ser compensada pela adição de novas observações. De qualquer forma, o ideal é obter o melhor resultado explanatório com o mínimo de variáveis independentes.

Isto é feito por meio da tentativa de se correlacionar uma única variável dependente às variáveis independentes (explanatórias) adicionais por meio de uma equação do tipo

$$
y=\beta_{0}+\beta_{1} x_{1}+\beta_{2} x_{2}+\cdots+\beta_{k} x_{k}+\varepsilon
$$

Sua validade também depende das condições descritas no item "método dos mínimos quadrados". Seu cálculo é bem mais complexo e convém seja feito por meio de uma ferramenta computacional, por exemplo, o módulo "ferramentas de análise de dados" do programa Microsoft Excel.

\section{Interpretação dos coeficientes}

Os coeficientes fornecidos pela ferramenta computacional indicam a sensibilidade da variável dependente às variáveis independentes. Isto é, o quanto uma variação unitária da grandeza associada à variável independente impacta na grandeza associada à variável dependente, quando mantidas as demais grandezas constantes.

O coeficiente da intersecção é, em geral, mais difícil de ser interpretado. Ele pode ter algum significado ou pode estar associado à parcela do resultado que não é explicada pelas varáveis independentes consideradas no modelo.

\section{Teste dos coeficientes $\beta \mathbf{i}$ da correlação}

Assim como ocorre no caso anterior, a significância do coeficiente, e consequentemente da variável independente, é avaliada por meio da hipótese nula $\mathrm{H}_{0}: \rho=0$ e a estatística de teste

$$
\begin{aligned}
& t=\frac{\widehat{\beta_{l}}}{s_{\widehat{\beta_{l}}}} \\
& |t|>t_{\alpha / 2, \mathrm{n}-\mathrm{k}-2}
\end{aligned}
$$

A região de rejeição será dada por

Esse teste pode ser facilmente aplicado porque a ferramenta computacional fornece os valores de estatística $t$ para cada uma das variáveis consideradas. Apesar de também ser fornecido um valor para o coeficiente da intersecção, em função das considerações anteriores, ele pode ser desprezado. A comparação entre os valores da estatística $t$ também indicam a força relativa de cada variável independente, e em função disso mesmo que uma determinada variável passe no teste, mas seu valor é limítrofe e menos significativo que as demais variáveis independentes, ela poderá ser desprezada sem causar prejuízo para a capacidade de predição do modelo.

\section{Avaliação do modelo}

É feito pelas seguintes três técnicas, cujos valores são fornecidos pela ferramenta computacional. 


\section{Erro padrão da estimativa}

O erro padrão, estimador do desvio padrão da população, é dado $\quad s_{\varepsilon}=\sqrt{\frac{S S E}{n-k-2}}$

Ele fornece alguma indicação sobre a qualidade do modelo, mas mais importante é ele permitir comparar o ajuste dos diferentes modelos.

\section{Coeficiente de determinação}

O coeficiente de determinação da regressão linear múltipla tem o mesmo significado é obtido pelas mesmas expressões do item correspondente anterior. Porém nesse caso, é melhor utilizar o coeficiente de determinação ajustado, igualmente fornecido pela ferramenta computacional, que também que leva em consideração o tamanho da amostra e o número de variáveis independentes.

Sua fórmula é

$$
\text { adjusted } r^{2}=1-\frac{S S E /(n-k-1)}{S S_{y} /(n-1)}
$$

\section{Análise de variância}

É utilizada para avaliar a utilidade do modelo, a semelhança do que é feito no item correspondente anterior, porém para o conjunto de variáveis independentes. Isso é feito por meio das hipóteses

Lembrando que

$$
\begin{aligned}
& H_{0}: \beta_{1}=\beta_{2}=\cdots=\beta_{k}=0 \\
& \mathrm{H}_{\mathrm{A}}: \text { pelo menos um } \beta_{i} \neq 0
\end{aligned}
$$

E que a média quadrada é a soma dos quadrados dividido pelo número de graus de liberdade, e ainda que a razão das médias quadradas é F-distribuída, desde que a população seja normal, a análise da variância é feita por meio de

\begin{tabular}{ccccc}
\hline $\begin{array}{c}\text { Fonte da } \\
\text { variação }\end{array}$ & $\begin{array}{c}\text { Graus de } \\
\text { liberdade }\end{array}$ & $\begin{array}{c}\text { Soma dos } \\
\text { quadrados }\end{array}$ & Média quadrada & Estatística F \\
\hline regressão & $\mathrm{k}$ & $S S R$ & $M S R=S S R / k$ & $F=M S R / M S E$ \\
resíduos & $\mathrm{n}-\mathrm{k}-1$ & $S S E$ & $M S E=S S E /(n-k-1)$ & \\
total & $\mathrm{n}-1$ & $S S_{y}$ & & \\
\hline
\end{tabular}

A estatística de teste que deve ser aplicada é

$$
F>F_{\alpha, k, n-k-1}
$$

Se essa condição for atendida, conclui-se que pelo menos um coeficiente $\beta_{i}$ é diferente de zero e o modelo é útil. O teste $\mathrm{F}$ é mais confiável que o conjunto de testes $\mathrm{t}$ aplicados a cada um dos coeficientes do modelo. Ele também permite identificar a ocorrência de colinearidade, discutida abaixo.

\section{Violação das premissas}

Para que as estatísticas de teste anteriores sejam válidas é necessário que diversas condições sejam satisfeitas. Grande parte dessas questões pode ser respondida examinando os resíduos, isto é, a diferença entre os valores de y observados e os determinados pela equação de regressão. Ou seja,

$$
e_{i}=y_{i}-\widehat{y}_{\imath}
$$




\section{Heterocedasticidade}

Se o gráfico dos resíduos mostra que os resíduos variam em função dos valores de y determinados pela equação de regressão, isso indica que a variância de $\varepsilon\left(\sigma_{\varepsilon}{ }^{2}\right)$ dependente do valor de $\mathrm{x}$ e, portanto, que a premissa que ela seja constante não foi atendida. A esta condição denomina-se heterocedasticidade.

O gráfico abaixo, obtido do caso em estudo, ao contrário, indica uma condição de homocedasticidade.

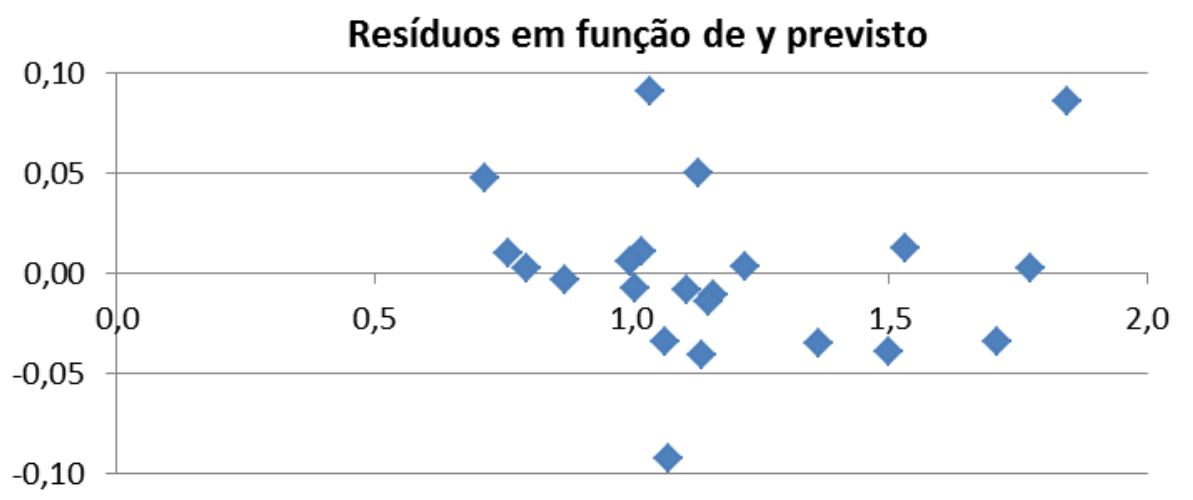

\section{Autocorrelação}

O gráfico dos resíduos em função do tempo também pode indicar algum vínculo entre os resíduos e o tempo, indicando que está ocorrendo uma condição denominada autocorrelação, condição na qual os valores de $\varepsilon$ não são independentes e, portanto, a violação dessa premissa.

O gráfico abaixo, obtido do caso em estudo, ao contrário, indica uma situação sem autocorrelação.

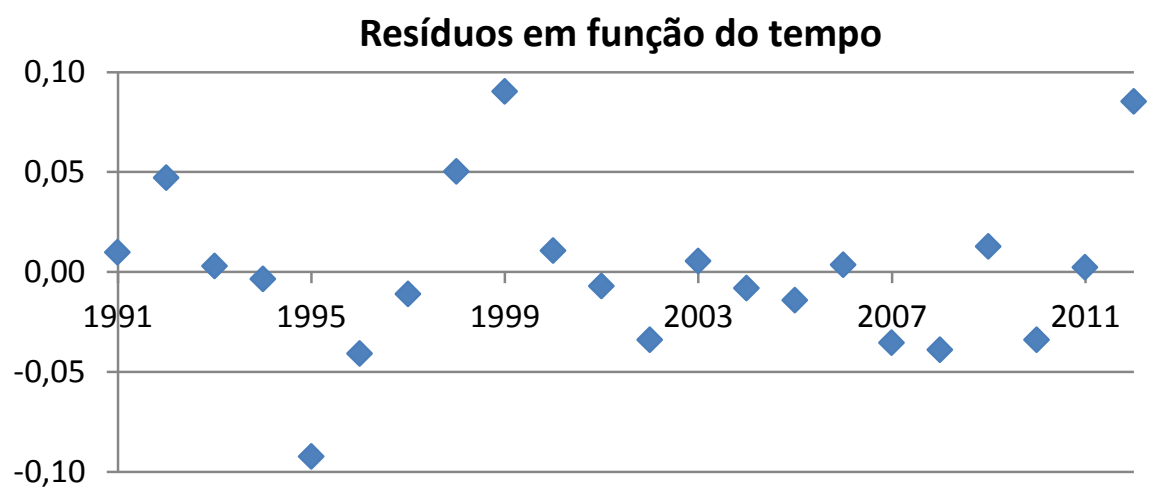

\section{Colinearidade}

Ocorre quando variáveis independentes se correlacionam entre si. Quando existe colinearidade, os desvios padrão dos coeficientes podem ser superestimados e, consequentemente, resultando em estatísticas t menores do que elas poderiam ser, e conduzindo a falsa conclusão que alguns $\beta_{i}$ sejam iguais à zero. Sua ocorrência pode ser detectada pela incompatibilidade entre os resultados das estatísticas t e F. 